\title{
BASELINE RISK ASSESSMENT OF GROUND WATER CONTAMINATION AT THE URANIUM MILL TAILINGS Site NeAR RIVERTON, WYOMING
}

September 1994

\section{DISCLAIMER}

This report was prepared as an account of work sponsored by an agency of the United States Government. Neither the United States Government nor any agency thereof, nor any of their employees, makes any warranty, express or implied, or assumes any legal liability or responsibility for the accuracy, completeness, or usefulness of any information, apparatus, product, or process disclosed, or represents that its use would not infringe privately owned rights. Reference herein to any specific commercial product, process, or service by trade name, trademark, manufacturer, or otherwise does not necessarily constitute or imply its endorsement, recommendation, or favoring by the United States Government or any agency thereof. The views and opinions of authors expressed herein do not necessarily state or reflect those of the United States Government or any agency thereof. 


\section{DISCLAIMER}

Portions of this document may be illegible in electronic image products. Images are produced from the best available original document. 
This report has been reproduced from the best available copy. Available in paper copy and microfiche.

Number of pages in this report: 160

DOE and DOE contractors can obtain copies of this report from:

Office of Scientific and Technical Information

P.O. Box 62

Oak Ridge, TN 37831

(615) 576-8401

This report is publicly available from:

National Technical Information Service

Department of Commerce

5285 Port Royal Road

Springfield, VA 22161

(703) $487-4650$ 
Prepared for

U.S. Department of Energy

UMTRA Project Office

Albuquerque, New Mexico

Prepared by

Jacobs Engineering Group Inc.

Albuquerque, New Mexico 


\section{CITIZENS' SUMMARY}

This Baseline Risk Assessment of Ground Water Contamination at the Uranium Mill Tailings Site Near Riverton, Wyoming, evaluates potential impacts to public health or the environment caused by ground water contamination at the former uranium mill processing site. In the first phase of the U.S. Department of Energy's Uranium Mill Tailings Remedial Action (UMTRA) Project, the tailings and other contaminated material at this site were placed in a disposal cell near the Gas Hills Plant in 1990. The second phase of the UMTRA Project is to evaluate ground water contamination. This risk assessment is the first site-specific document to evaluate potential health and environmental risks for the Riverton site under the Ground Water Project; it will help determine whether remedial actions are needed for contaminated ground water at the site.

\section{Potential public health impacts}

Contaminants from uranium processing have been detected in shallow ground water. Although a shallow well is sometimes used for livestock, no known drinking water wells tap the contaminated ground water. Ground water from deeper aquifers in the vicinity is used for drinking water. This risk assessment evaluates the potential future use of the contaminated ground water for drinking and potential current use for livestock.

This risk assessment follows the basic approach prescribed by the U.S. Environmental Protection Agency. The first step is to evaluate ground water data collected from monitor wells at the site over the last 5 years. Evaluation of these data shows the main contaminants associated with the site are manganese, molybdenum, sulfate, and uranium.

The next step in the risk assessment is to estimate how much of these contaminants people would be exposed to if a drinking well were installed in the contaminated ground water. Because the contaminant concentrations vary each time a well is sampled and because people vary in how much they weigh and drink, this risk assessment uses probability distributions to determine the amounts of contaminants people would ingest by drinking from a hypothetical well at the site. The probability distributions describe how likely it is for something to happen. For example, based on population surveys, probability distributions can describe the percentages of people who drink a half-gallon or only a cup of water each day.

People can ingest contaminants by eating garden vegetables watered with contaminated ground water or if their milk or meat comes from domestic animals pastured on land that contains or is watered with contaminated ground water. Eating fish from the Little Wind River or accidentally ingesting the river's water during recreation can also expose people to contamination. The estimated amounts of contaminants that people might take in from these routes are then compared to the toxic effects these contaminant levels might cause. Based on this analysis, no adverse health effects would be expected following ingestion of milk and meat from animals or from ingestion of garden produce. Recreational use of the Little Wind River also would not be expected to represent a hazard to humans. However, direct consumption of shallow ground water contaminated by the former processing site could represent a concern. 
Sulfate is the most significant health hazard in the shallow ground water at the Riverton mill site. Sulfate is of special concern for infants: at the levels found at the site, severe sulfate-induced diarrhea could lead to dehydration more quickly than it would in children or aduits. Although no one currently drinks this contaminated ground water, the sulfate levels in this ground water exceed levels that have been reported elsewhere to cause severe dehydration when ingested by infants.

Other contaminants that occur at toxic levels at the Riverton site are manganese, molybdenum, and uranium. If the shallow contaminated ground water were used for drinking water, manganese could cause neurologic changes, molybdenum could lead to gout, and uranium ingestion could lead to an increased risk of cancer. The additional lifetime cancer risk from ingesting uranium-contaminated ground water would average 3 in 1000.

\section{Potential environmental impacts}

Contaminated ground water could potentially impact the environment. Based on data from monitor wells near the river and surface water and sediment quality data, it appears that contaminated ground water has reached the Little Wind River near the site. Based on data and criteria available for a number of the contaminants of potential concern, no ecological threat exists to plants at harvestable maturity that may have roots in contact with soil saturated with the most contaminated ground water in the surficial aquifer. However, this ground water would not be suitable for continuous crop irrigation because manganese and molybdenum could build up to toxic levels in the soil following long-term use.

This risk assessment also evaluated potential effects on livestock if the ground water were used to water cattle or sheep. These animals are sensitive to sulfate and molybdenum. Sulfate concentrations near the mill site exceed safe levels and could lead to severe diarrhea. Molybdenum also could be taken up by plants at levels that, in combination with elevated sulfate levels in drinking water, could be harmful.

As part of the current Riverton monitoring program, wells are sampled routinely. This ongoing site evaluation will include further characterization of ground water movement. Based on these results and this risk assessment, an approach will be proposed for managing the contaminated ground water. The overall ground water decision-making framework will be presented in a programmatic environmental impact statement, and sitespecific remedial action decisions will be presented in an environmental assessment. Both of these will include public and tribal involvement. Meanwhile, ways to control access to contaminated ground water should be pursued. 


\section{TABLE OF CONTENTS}

\section{Section}

CITIZENS' SUMMARY $\ldots \ldots \ldots \ldots \ldots \ldots \ldots \ldots \ldots \ldots \ldots \ldots \ldots \ldots \ldots$

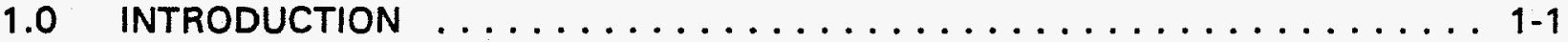

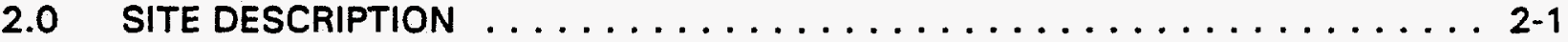

$2.1 \quad$ Site background $\ldots \ldots \ldots \ldots \ldots \ldots \ldots \ldots \ldots \ldots \ldots \ldots \ldots \ldots \ldots \ldots \ldots, 1$

2.2 Climate $\ldots \ldots \ldots \ldots \ldots \ldots \ldots \ldots \ldots \ldots \ldots \ldots \ldots \ldots \ldots \ldots \ldots \ldots \ldots \ldots, 1$

2.3 Surface water flow patterns $\ldots \ldots \ldots \ldots \ldots \ldots \ldots \ldots \ldots \ldots 2-1$

2.4 Hydrogeologr ......................... 2-3

2.4.1 Surficial unconfined aquifer $\ldots \ldots \ldots \ldots \ldots \ldots \ldots \ldots .2-3$

2.4.2 Semiconfined sandstone .................. 2-7

2.4.3 Confined sandstone $\ldots \ldots \ldots \ldots \ldots \ldots \ldots \ldots \ldots \ldots \ldots . \ldots \ldots$

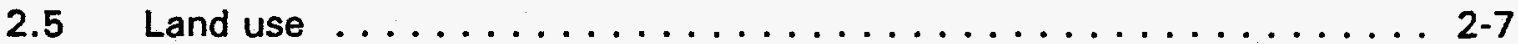

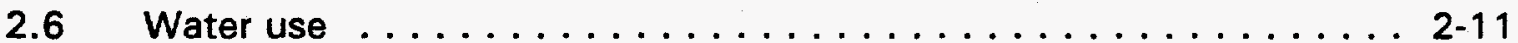

3.0 EXTENT OF CONTAMINATION ..................... 3-1

3.1 Background water quality summary $\ldots \ldots \ldots \ldots \ldots \ldots \ldots \ldots$ 3-1

3.1.1 Surficial unconfined aquifer $\ldots \ldots \ldots \ldots \ldots \ldots \ldots \ldots$ 3-1

3.1.2 Semiconfined aquifer $\ldots \ldots \ldots \ldots \ldots \ldots \ldots \ldots \ldots$ 3-1

3.2 Magnitude of site-related contamination $\ldots \ldots \ldots \ldots \ldots \ldots \ldots$ 3-10

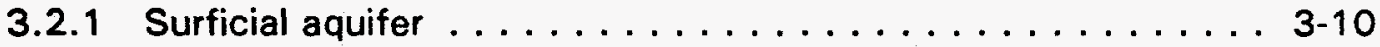

3.2.1 Semiconfined aquifer $\ldots \ldots \ldots \ldots \ldots \ldots \ldots \ldots \ldots, 3-17$

3.3 Contaminants of potential concern ................ 3-17

3.4 Contaminant fate and transport $\ldots \ldots \ldots \ldots \ldots \ldots \ldots \ldots \ldots .20 \ldots \ldots$

3.5 Surface watering monitoring $\ldots \ldots \ldots \ldots \ldots \ldots \ldots \ldots \ldots, 22$

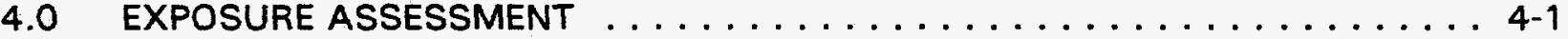

4.1 Potentially exposed population $\ldots \ldots \ldots \ldots \ldots \ldots \ldots \ldots \ldots \ldots, 4-1$

4.2 Exposure pathways ........................ 4-1

4.2.1 Drinking water ingestion $\ldots \ldots \ldots \ldots \ldots \ldots \ldots \ldots \ldots, 4,3$

4.2.2 Dermal absorption .................... 4-3

4.2.3 Ingestion of ground water irrigated produce $\ldots \ldots \ldots \ldots .44$

4.2.4 Ingestion of meat from ground water fed livestock ... . . . 4 4-3

4.2.5 Ingestion of milk from ground water-fed livestock ....... 4-10

4.2.6 Incidental ingestion of surface water while swimming and ingestion of fish from the Little Wind River .......... 4-10

4.2.7 Incidental ingestion of sediment during recreational activities . 4-10

4.3 Exposure concentrations for drinking water . . . . . . . . . 4-16

4.4 Estimated drinking water intake $\ldots \ldots \ldots \ldots \ldots \ldots \ldots \ldots . \ldots \ldots$

4.5 Exposure assessment uncertainties . . . . . . . . . . . . 26

5.0 TOXICITY ASSESSMENT $\ldots \ldots \ldots \ldots \ldots \ldots \ldots \ldots \ldots \ldots \ldots \ldots \ldots$ 5-1

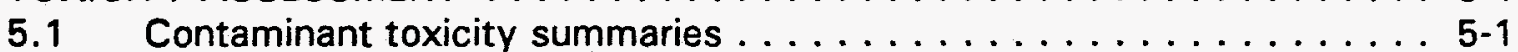

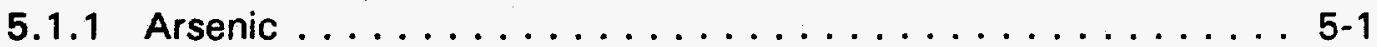


TABLE OF CONTENTS (Concluded)

Section

Page

5.1 .2 Manganese ....................... 5-4

5.1 .3 Molybdenum ....................... 5-8

5.1 .4 Nickel . . . . . . . . . . . . . . . . . . . 5-10

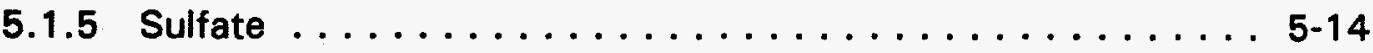

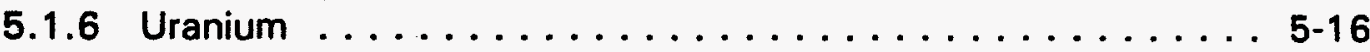

5.1 .7 Vanadium ........................ 5-21

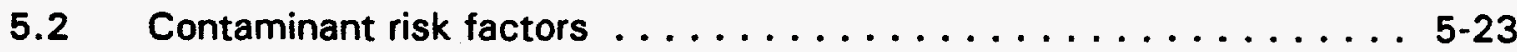

5.3 Contaminant interactions . . . . . . . . . . . . . 5-26

6.0 RISK EVALUATION .......................... 6.1

6.1 Potential noncarcinogenic health effects $\ldots \ldots \ldots \ldots \ldots \ldots \ldots \ldots$

6.2 Potential carcinogenic health effects . . . . . . . . . . . 6 6-10

6.3 Limitations of this risk evaluation . . . . . . . . . . . . 6-11

7.0 LIVESTOCK AND ENVIRONMENTAL EVALUATION $\ldots \ldots \ldots \ldots \ldots \ldots$

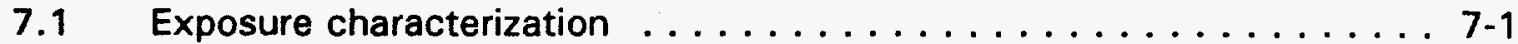

7.2 Ecological receptors ........................ $7-2$

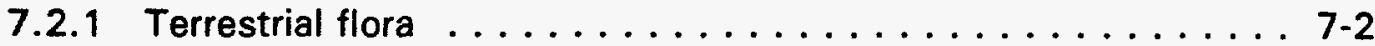

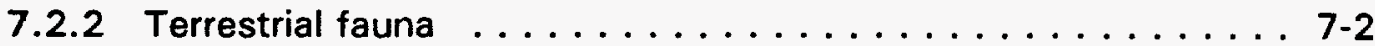

7.2.3 Aquatic life ...................... $7-4$

7.3 Contaminants of ecological concern ............... $7-5$

7.4 Potential impacts to terrestrial and aquatic life . . . . . . . . . . . 7-6

7.4.1 Risk to terrestrial life ................. 7-6

7.4.2 Risk to aquatic life ................ $7-8$

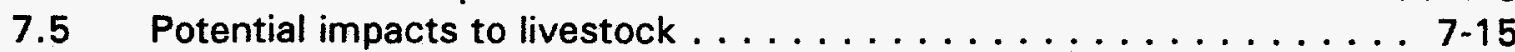

7.6 Limitations of the ecological risk assessment . . . . . . . . 7-15

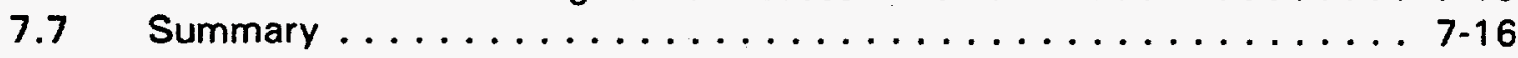

8.0 INTERPRETATION AND RECOMMENDATIONS $\ldots \ldots \ldots \ldots \ldots \ldots \ldots$

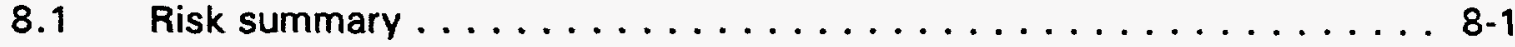

8.2 Limitations of this risk assessment $\ldots \ldots \ldots \ldots \ldots \ldots \ldots \ldots . \ldots \ldots$

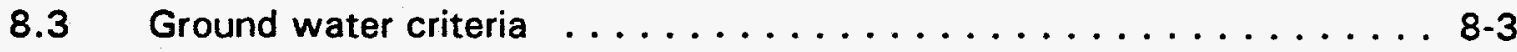

8.4 Risk mitigation measures $\ldots \ldots \ldots \ldots \ldots \ldots \ldots \ldots \ldots \ldots \ldots \ldots$

8.5 Recommendations . . . . . . . . . . . . . . . 8:6

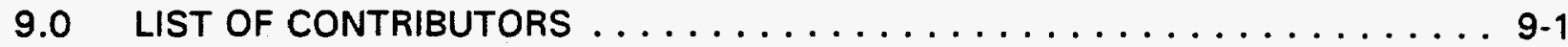

10.0 REFERENCES $\ldots \ldots \ldots \ldots \ldots \ldots \ldots \ldots \ldots \ldots \ldots \ldots \ldots \ldots \ldots$ 


\section{LIST OF FIGURES}

Figure

$\underline{\text { Page }}$

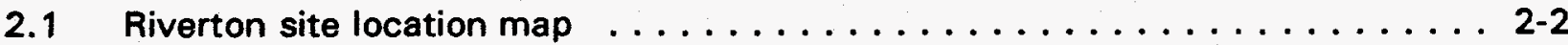

2.2 Existing drainage conditions and location of geologic cross section, Riverton, Wyoming, site ....................... 2-4

2.3 Geologic cross section, Riverton, Wyoming, site . . . . . . . . . . . . 2-5

2.4 Ground water elevations in the surficial aquifer, Riverton, Wyoming, site . . . . 2-6

2.5 Ground water elevations in the semiconfined sandstone aquifer, Riverton, Wyoming, site . . . . . . . . . . . . . . . . . . . . . 2-8

2.6 Ground water elevations in the confined sandstone aquifer, Riverton, Wyoming, site . . . . . . . . . . . . . . . . . . . . . . 2-9

2.7 Domestic wells in the vicinity of the Riverton, Wyoming, site . . . . . . . 2-10

3.1 Monitor well locations, Riverton, Wyoming, site . . . . . . . . . . . 3-2

3.2 Trilinear plot of composition of background ground water, Riverton, Wyoming, site ............................ 3-4

3.3 Isopleths showing uranium concentrations in the surficial aquifer, Riverton, Wyoming, site .......................... 3-14

3.4 Isopleths showing molybdenum concentrations in the surficial aquifer, Riverton, Wyoming, site . . . . . . . . . . . . . . . . . . . 3-15

3.5 Isopleths showing sulfate concentrations in the surficial aquifer, Riverton, Wyoming, site ......................... 3-16

3.6 Isopleths showing sulfate concentrations in the semiconfined aquifer, Riverton, Wyoming, site . . . . . . . . . . . . . . . . . . .

4.1 Riverton site conceptual model . . . . . . . . . . . . . . . . 4-2

4.2 Simulated distribution of arsenic concentrations, Riverton, Wyoming, site . . 4-17

4.3 Simulated distribution of manganese concentrations, Riverton, Wyoming,

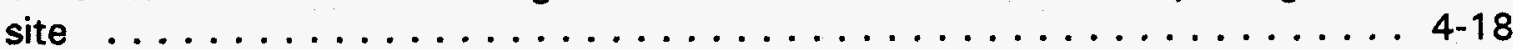

4.4 Simulated distribution of molybdenum concentrations, Riverton, Wyoming,

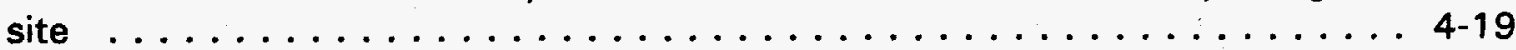

4.5 Simulated distribution of nickel concentrations, Riverton, Wyoming, site . . . 4-20

4.6 Simulated distribution of sulfate concentrations, Riverton, Wyoming, site . . . 4-21

4.7 Simulated distribution of uranium concentrations, Riverton, Wyoming, site . . 4-22

4.8 Simulated distribution of vanadium concentrations, Riverton, Wyoming, site . 4-23

4.9 Probability distributions for tap water ingestion rates . . . . . . . . . . 4-25

4.10 Probability distributions for body weight . . . . . . . . . . . . . 4-27

4.11 Comparison of distributions of potential uranium exposures as a result of drinking contaminated ground water for the three age groups examined,

Riverton, Wyoming, site . . . . . . . . . . . . . . . . 4-28

4.12 Probability distribution of arsenic intakes for children as a result of ground water ingestion, Riverton, Wyoming, site . . . . . . . . . . . . . 4-29

4.13 Probability distribution of manganese intakes for children as a result of ground water ingestion, Riverton, Wyoming, site . . . . . . . . . . 4-30

4.14 Probability distribution of molybdenum intakes for children as a result of ground water ingestion, Riverton, Wyoming, site . . . . . . . . . . 4-31 


\section{LIST OF FIGURES (Continued)}

Figure

4.15 Probability distribution of nickel intakes for children as a result of ground water ingestion, Riverton, Wyoming, site

4.16 Probability distribution of sulfate intakes for infants as a result of ground water ingestion, Riverton, Wyoming, site .............. 4-33

4.17 Probability distribution of uranium intakes for children as a result of ground water ingestion, Riverton, Wyoming, site . . . . . . . . . . . 4-34

4.18 Probability distribution of vanadium intakes for children as a result of ground water ingestion, Riverton, Wyoming, site . . . . . . . . . 4-35

5.1 Arsenic toxicity ranges . . . . . . . . . . . . . . . . . . 5-5

5.2 Manganese toxicity ranges . . . . . . . . . . . . . . . . . . 5 5

5.3 Molybdenum toxicity ranges ....................... 5 .11

5.4 Nickel toxicity ranges . . . . . . . . . . . . . . . . . . . . $5-13$

5.5 Sulfate toxicity ranges . . . . . . . . . . . . . . . . . . 5-17

5.6 Half-lives and emissions from decay chain of uranium-238 . . . . . . . 5-18

5.7 Uranium toxicity ranges . . . . . . . . . . . . . . . . . . 5-20

5.8 Vanadium toxicity ranges . . . . . . . . . . . . . . . . . . 5-24

6.1 Health effects of potential arsenic exposure ranges for children, Riverton, Wyoming, site . . . . . . . . . . . . . . . . . . . . . 6-2

6.2 Health effects of potential manganese exposure ranges for children, Riverton, Wyoming, site ........................... 6-3

6.3 Health effects of potential molybdenum exposure ranges for children, Riverton, Wyoming, site . . . . . . . . . . . . . . . . . . . 6-4

6.4 Health effects of potential sulfate exposure ranges for children, Riverton, Wyoming, site ........................... 6-5

6.5 Health effects of potential nickel exposure ranges for children, Riverton, Wyoming, site . . . . . . . . . . . . . . . . . . . . 6-6

6.6 Health effects of potential uranium exposure ranges for children, Riverton, Wyoming, site ............................ 6-7

6.7 Health effects of potential vanadium exposure ranges for children, Riverton, Wyoming, site ........................... 6-8

7.1 Surface water and sediment sample locations, Riverton, Wyoming, site . . . 7-3 


\section{LIST OF TABLES}

Table

Page

2.1 Domestic well sampling, construction, and use information, Riverton, Wyoming ...........................

3.1 Ground water monitor well information, Riverton, Wyoming . . . . . . . . . 3-3

3.2 Statistical summary of filtered ground water quality in the surficial aquifer at Riverton (1987 to 1993 sampling) . . . . . . . . . . . . . . . . . . . 3-5

3.3 Summary of filtered ground water quality for the contaminants of concern in the semiconfined aquifer at Riverton (1993 sampling) . . . . . . . . . . . 3-11

3.4 Contaminants of potential concern in surficial ground water . . . . . . . . . 3-19

3.5 Aqueous species and molar percentage of hazardous contaminants in ground water in the surficial aquifer downgradient from the Riverton,

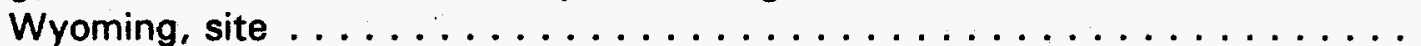

4.1 Exposure dose calculations and equation definitions for ground water ingestion and dermal contact, Riverton UMTRA Project site, Riverton, Wyoming .............................. . 4-4

4.2 Exposure dose calculations and equation definitions for ground water-irrigated garden produce ingestion, Riverton UMTRA Project site, Riverton, Wyoming

4.3 Exposure dose calculations and equation definitions for ingestion of meat from ground water-fed cattle, Riverton UMTRA Project site, Riverton, Wyoming ................................ 4-8

4.4 Exposure dose calculations and equation definitions for ingestion of milk from ground water-fed cattle, Riverton UMTRA Project site, Riverton, Wyoming

4.5 Exposure dose calculations and equation definitions for incidental surface water ingestion and ingestion of fish from the Little Wind River, Riverton UMTRA Project site, Riverton, Wyoming . . . . . . . . . . . . . 4-13

4.6 Exposure dose calculations and equation definitions for incidental sediment ingestion during recreational use of the Little Wind River and other surrounding water bodies, Riverton UMTRA Project site, Riverton, Wyoming

5.1 Toxicity values: potential noncarcinogenic effects $\ldots \ldots \ldots \ldots \ldots \ldots$. . . . 5 25

5.2 Toxicity values: potential carcinogenic effects . . . . . . . . . . . . 5-27

6.1 Carcinogenic risk for ground water consumption pathway at Riverton,

7.1 Comparison of estimated plant concentrations to phytotoxic concentrations, Riverton UMTRA Project site, Riverton, Wyoming . . . . . . . . . . . 7-7

7.2 Comparison of contaminants of potential concern in ground water with available water quality values, Riverton UMTRA Project site, Riverton,

Wyoming 


\section{LIST OF TABLES (Continued)}

Table

Page

7.3 Occurrence of constituents in the Little Wind River surface water, June 1993 sampling event, Riverton UMTRA Project site, Riverton, Wyoming

7.4 Occurrence of constituents in the Little Wind River sediments, June 1993 sampling event, Riverton UMTRA Project site, Riverton, Wyoming

7.5 Occurrence of constituents in surface water from water bodies in the site vicinity, June 1993 sampling event, Riverton UMTRA Project site, Riverton, Wyoming

7.6 Occurrence of constituents in sediments from water bodies in the site vicinity, July 1993 sampling event, Riverton UMTRA Project site, Riverton, Wyoming

8.1 Concentration limits of constituents $\ldots \ldots \ldots \ldots \ldots \ldots \ldots \ldots$ 


\title{
LIST OF ACRONYMS AND ABBREVIATIONS
}

\author{
Acronym \\ ac \\ $A C L$ \\ $B C F$ \\ BIA \\ ${ }^{\circ} \mathrm{C}$ \\ $\mathrm{cm}$ \\ $\mathrm{cm}^{2}$ \\ $\mathrm{cm} /$ hour \\ DHHS \\ DOE \\ EA \\ EPA \\ ER-L \\ ${ }^{\circ} \mathrm{F}$ \\ ft \\ FWOC \\ $\mathrm{g}$ \\ ha \\ HEAST \\ IRIS \\ kg \\ $\mathrm{kg} /$ day \\ $\mathrm{km}$ \\ $\mathrm{L} / \mathrm{cm}^{3}$ \\ L/day \\ L/kg \\ L/hour \\ LOAEL \\ $\mu \mathrm{g}$ \\ $\mu \mathrm{g} / \mathrm{g}$ \\ $\mu \mathrm{g} / \mathrm{kg}$ \\ $\mu g / d a y$ \\ $\mu \mathrm{g} / \mathrm{L}$ \\ $m$ \\ $\mathrm{m}^{3}$ \\ $\mathrm{MCL}$ \\ $\mathrm{mg}$ \\ $\mathrm{mg} / \mathrm{day}$ \\ $\mathrm{mg} / \mathrm{kg}$ \\ $\mathrm{mg} / \mathrm{kg}$-day \\ $\mathrm{mg} / \mathrm{L}$

\section{Definition} \\ acre \\ alternate concentration limit \\ bioconcentration factor \\ Bureau of Indian Affairs \\ degrees Celsius \\ centimeter \\ square centimeter \\ centimeters per hour \\ U.S. Department of Health and Human Services \\ U.S. Department of Energy \\ environmental assessment \\ U.S. Environmental Protection Agency \\ effects range-low \\ degrees Fahrenheit \\ foot \\ Federal Water Quality Criteria \\ gram \\ hectare \\ Health Effects Assessment Summary Tables \\ Integrated Risk Information System \\ kilogram \\ kilograms per day \\ kilometer \\ liter per cubic centimeter \\ liters per day \\ liters per kilogram \\ liters per hour \\ lowest-observed-adverse-effect level \\ microgram \\ micrograms per gram \\ micrograms per kilogram \\ micrograms per day \\ micrograms per liter \\ meter \\ cubic meter \\ maximum concentration limit \\ milligram \\ milligrams per day \\ milligrams per kilogram \\ milligrams per kilogram per day \\ milligrams per liter
}




\section{LIST OF ACRONYMS AND ABBREVIATIONS (Concluded)}

\section{Acronym}

mi

micromhos $/ \mathrm{cm}$

MSL

ng

$\mathrm{ng} / \mathrm{mL}$

NOAA

NOAEL

$\mathrm{pCi}$

$\mathrm{pCi} / \mathrm{L}$

PEIS

ppm

RfD

SF

SQC

TDS

UMTRA

UMTRCA

$\mathrm{yd}^{3}$

\section{Definition}

mile

micromhos per centimeter

mean sea level

nanogram

nanograms per milliliter

National Oceanic and Atmospheric Administration

no-observed-adverse-effect level

picocurie

picocuries per liter

program environmental impact statement

parts per million

reference dose

slope factor

sediment quality criteria

total dissolved solids

Uranium Mill Tailings Remedial Action

Uranium Mill Tailings Radiation Control Act

cubic yard 


\subsection{INTRODUCTION}

The purpose of this baseline risk assessment is to determine whether ground water contamination at the Riverton, Wyoming, uranium mill tailings site could adversely affect public health or the environment. The Riverton site is one of 24 abandoned uranium mill tailings sites undergoing remediation in accordance with the requirements of the Uranium Mill Tailings Radiation Control Act (UMTRCA) of 1978 (42 USC $\$ 7901$ et seq.) under the oversight of the U.S. Department of Energy (DOE).

The purpose of the Uranium Mill Tailings Remedial Action (UMTRA) Surface Project is to stabilize the tailings in a disposal cell that will minimize radon, other radiation emissions, and further contamination of ground water. At the Riverton site, surface remedial action was completed in 1990 with relocation and stabilization of the tailings in a disposal cell near the Gas Hills Plant.

The purpose of the UMTRA Ground Water Project is to evaluate ground water contamination at the 24 sites, determine whether action is necessary, and implement that action. Under 1988 amendments to the UMTRCA, the DOE is authorized to perform ground water restoration.

Strategies to evaluate and methods to clean up contaminated ground water at the UMTRA Project sites are described in the Programmatic Environmental Impact Statement for the Uranium Mill Tailings Remedial Action Ground Water Project (DOE, 1994). This baseline risk assessment is the first site-specific document for Riverton to evaluate potential health and environmental risks and provide information to assist in determining what remedial action is necessary. A site-specific environmental assessment (EA) will be prepared to evaluate and select remedial action for Riverton after the programmatic environmental impact statement (PEIS) and risk assessment are completed.

This risk assessment is a baseline assessment in the sense that it describes preremediation ground water conditions at the site, with ground water contamination only partially characterized. Nonetheless, this document evaluates the potential for imminent public health or environmental risk that may need attention before the site is fully characterized.

The evaluation is based on available ground water data from the most contaminated wells at the processing site, and only major exposure pathways have been thoroughly examined. If future data collection, decisions, or actions at this site cause conditions to change, other pathways will be evaluated in more detail.

This risk assessment follows the basic framework outlined by the U.S. Environmental Protection Agency (EPA) (EPA, 1989) for evaluating hazardous-waste sites to assess potential health and environmental impacts. The risk assessment process consists of the following steps: 
- Data evaluation.

- Combining data from various site investigations.

- Comparing sample results with background and tailings source data.

- Selecting chemical data for use in the risk assessment.

- Exposure assessment.

- Characterizing exposure settings.

- Identifying exposure pathways.

- Quantifying exposure.

- Toxicity assessment.

- Identifying toxicity values.

- Evaluating noncarcinogenic effects.

- Evaluating carcinogenic effects from radionuclides and chemical carcinogens.

- Public health risk characterization.

- Comparing toxicity ranges to predicted exposure ranges.

- Combining risks across exposure pathways and multiple contaminants.

- Characterizing uncertainties.

- Environmental risk.

- Characterizing potential biota exposure pathways.

- Identifying potential ecological receptors.

- Evaluating environmental risk qualitatively.

This framework is incorporated in the methodology used to evaluate current human health risks at UMTRA Project sites and to estimate risks from potential future use of contaminated ground water or surface water near the former Riverton site. A report describing this methodology is in preparation. 


\subsection{SITE DESCRIPTION}

The Riverton site is in Fremont County, Wyoming, 2 miles (mi) ( 3 kilometers [km]) southwest of the city of Riverton (Figure 2.1). The site is on private land, within the boundaries of the Wind River Indian Reservation (Arapahoe and Shoshone Indian Tribes).

\subsection{SITE BACKGROUND}

The mill at the Riverton tailings site was constructed in 1958 and shut down in 1963. Fremont Minerals, Inc. initially operated the mill, treating a variety of uranium ores from the surrounding area. The company name subsequently was changed to Susquehanna-Western, Inc. During its 4 years of operation, the mill processed approximately 900,000 tons $(800,000$ metric tons) of ore. Waste solids from the uranium ores were transferred to a tailings pile. This rectangular pile covered 70 acres (ac) (30 hectares [ha]) and contained approximately 1 million cubic yards $\left(\mathrm{yd}^{3}\right)\left(800,000\right.$ cubic meters $\left.\left[\mathrm{m}^{3}\right]\right)$ of tailings. The mill property also included a sulfuric acid plant, which is still in operation.

Between 1988 and 1990, the uranium mill tailings pile and contaminated soils were removed from the site. Approximately 1.8 million $\mathrm{yd}^{3}\left(1.4\right.$ million $\left.\mathrm{m}^{3}\right)$ of contaminated material were relocated to a disposal cell near the Gas Hills Plant. The excavated areas were backfilled with clean fill; the finished land surface was graded to form a crown and planted with rye grass.

\subsection{CLIMATE}

The Riverton area is arid, due largely to the influence of the Wind River mountain range to the west that hinders the passage of moisture. The average annual precipitation in Riverton from 1951 to 1980 was 8 inches

(20 centimeters $[\mathrm{cm}]$ ), with the greatest amount of precipitation occurring from April through June. Much of the precipitation is in the form of showers and thundershowers from the spring through the fall (DOE, 1987).

The Riverton area experiences wide and sudden changes in temperature because of the high elevation (approximately 4940 feet ( $\mathrm{ft}$ ) (1500 meters [m]) and the presence of dry air. Riverton is influenced both by cold masses from Canada and by prevailing warm, westerly winds. The highest and lowest temperatures recorded in Riverton from 1951 to 1980 were 104 degrees Fahrenheit ( $\left.{ }^{\circ} \mathrm{F}\right)$ (40 degrees Celsius $\left.\left[{ }^{\circ} \mathrm{C}\right]\right)$ and $-46^{\circ} \mathrm{F}\left(-43^{\circ} \mathrm{C}\right)$, respectively. During the same period, an average of 207 days per year had minimum temperatures less than or equal to $32^{\circ} \mathrm{F}\left(0^{\circ} \mathrm{C}\right)$, and an average of 37 days per year had maximum temperatures of $90^{\circ} \mathrm{F}\left(32^{\circ} \mathrm{C}\right)$ or greater.

\subsection{SURFACE WATER FLOW PATTERNS}

The Riverton site is on a nearly level surficial terrace in the Wind River basin, approximately $13,000 \mathrm{ft}(4000 \mathrm{~m})$ upstream of the confluence of the Wind and 


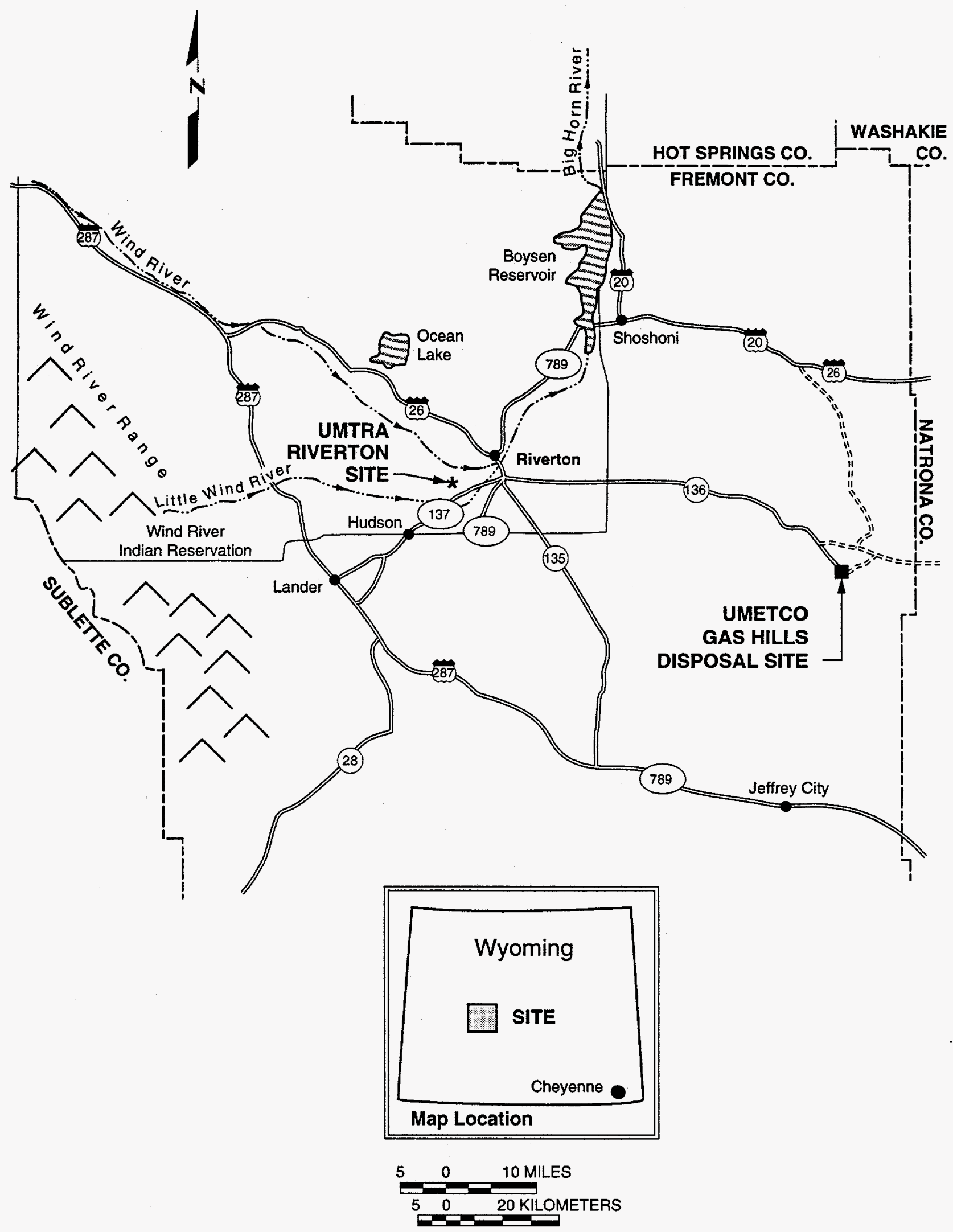

FIGURE 2.1

RIVERTON SITE LOCATION MAP 
Little Wind Rivers. The Wind River is approximately $4000 \mathrm{ft}(1000 \mathrm{~m})$ north of the site and the Little Wind River is approximately $3000 \mathrm{ft}(900 \mathrm{~m})$ southeast of the site (Figure 2.2). A stream and wetland area lies approximately $1000 \mathrm{ft}$ $(300 \mathrm{~m})$ north of the northern property line. This stream joins the Wind River approximately $5500 \mathrm{ft}(1700 \mathrm{~m})$ east of the northeastern corner of the site.

A drainage channel is excavated in a natural wetland area along the western side of the property. This channel and wetland are joined by a second channel that carries discharge water from the sulfur processing site on the western edge of the property. These channels pass under Highway 137 and join the Little Wind River approximately $3500 \mathrm{ft}(1100 \mathrm{~m})$ due south of the property.

Drainage from another wetland area east of the site passes under Highway 137 approximately $2500 \mathrm{ft}(760 \mathrm{~m})$ east of the southeastern corner of the property. A system of former irrigation canals and ditches along the northern and eastern sides of the property channels seasonal surface water flow.

These natural wetland areas, streams, and rivers and man-made drainage ditches and channels may intercept the shallow ground water in the alluvium and could form hydraulic barriers.

\subsection{HYDROGEOLOGY}

This baseline risk assessment considers the upper five hydrogeologic units in this area. They are, in descending order from the land surface, an unconfined surficial alluvial and sandstone aquifer 15 to $20 \mathrm{ft}(5$ to $6 \mathrm{~m})$ thick; a leaky shale aquitard 5 to $10 \mathrm{ft}(2$ to $3 \mathrm{~m})$ thick; a semiconfined sandstone aquifer 15 to 30 ft $(5$ to $9 \mathrm{~m})$ thick; a second, more impermeable shale aquitard approximately 40 $\mathrm{ft}(12 \mathrm{~m})$ thick; and a confined sandstone aquifer at least $50 \mathrm{ft}(17 \mathrm{~m})$ thick (Figure 2.3). The unconfined surficial aquifer, semiconfined sandstone aquifer, and confined sandstone aquifer are discussed in more detail in the following paragraphs.

\subsubsection{Surficial unconfined aquifer}

The surficial unconfined aquifer consists of sand and gravel underlain by a discontinuous layer of sandstone. The sandstone layer north and south of the former tailings pile pinches out near the southern edge of the site. There is no aquitard between the surficial sediments and this sandstone layer.

In March 1993, the water table in the unconfined, surficial aquifer beneath the site ranged from approximately $10 \mathrm{ft}(3 \mathrm{~m})$ below the ground surface near the northwest corner of the former tailings pile (elevation $4936 \mathrm{ft}[1504 \mathrm{~m}]$ ) mean sea level (MSL) to about $6 \mathrm{ft}(2 \mathrm{~m})$ below land surface near the southeast corner of the site (elevation $4930 \mathrm{ft}[1500 \mathrm{~m}] \mathrm{MSL}$ ). Ground water flows eastsoutheast with a gradient of approximately 0.002 (Figure 2.4). 


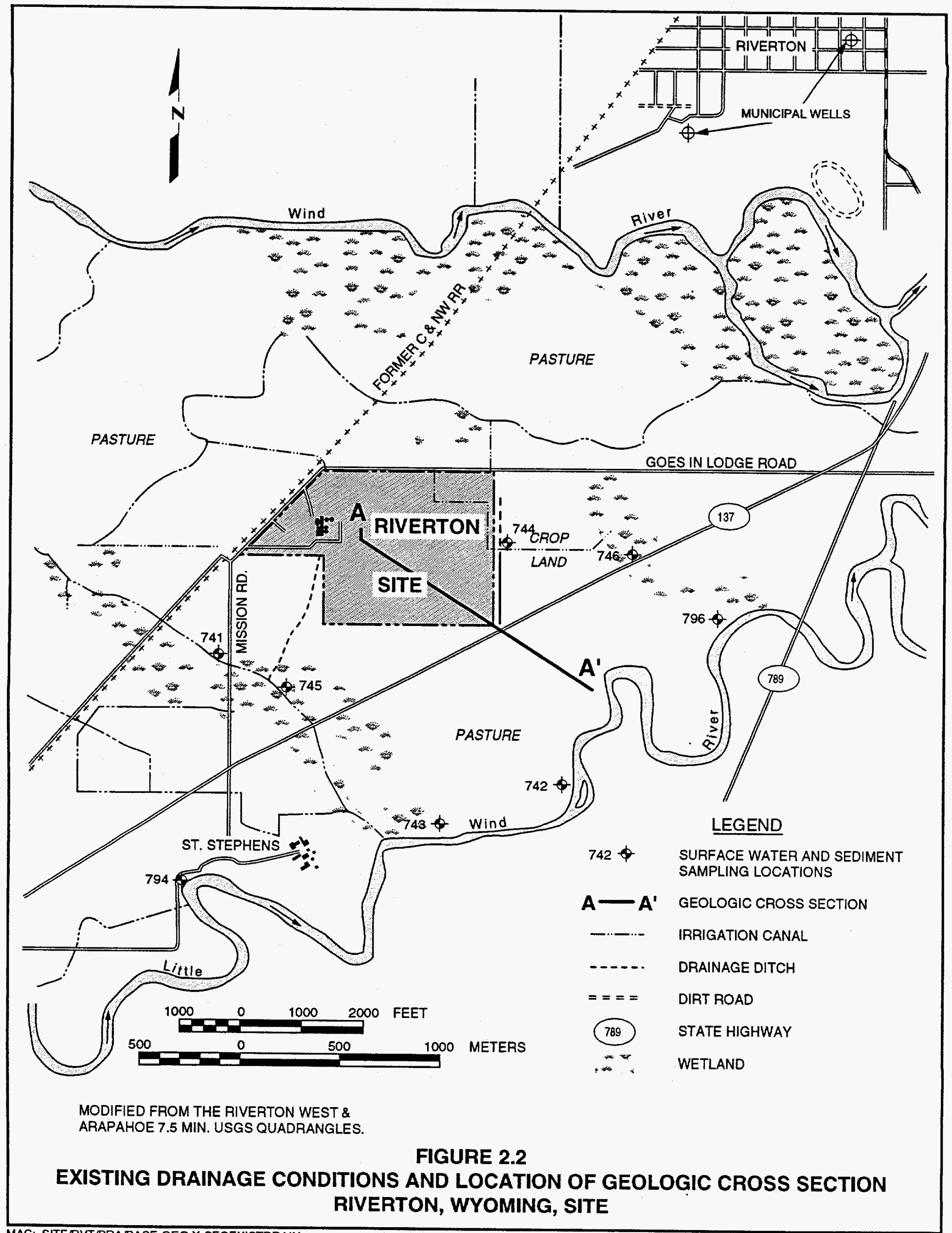




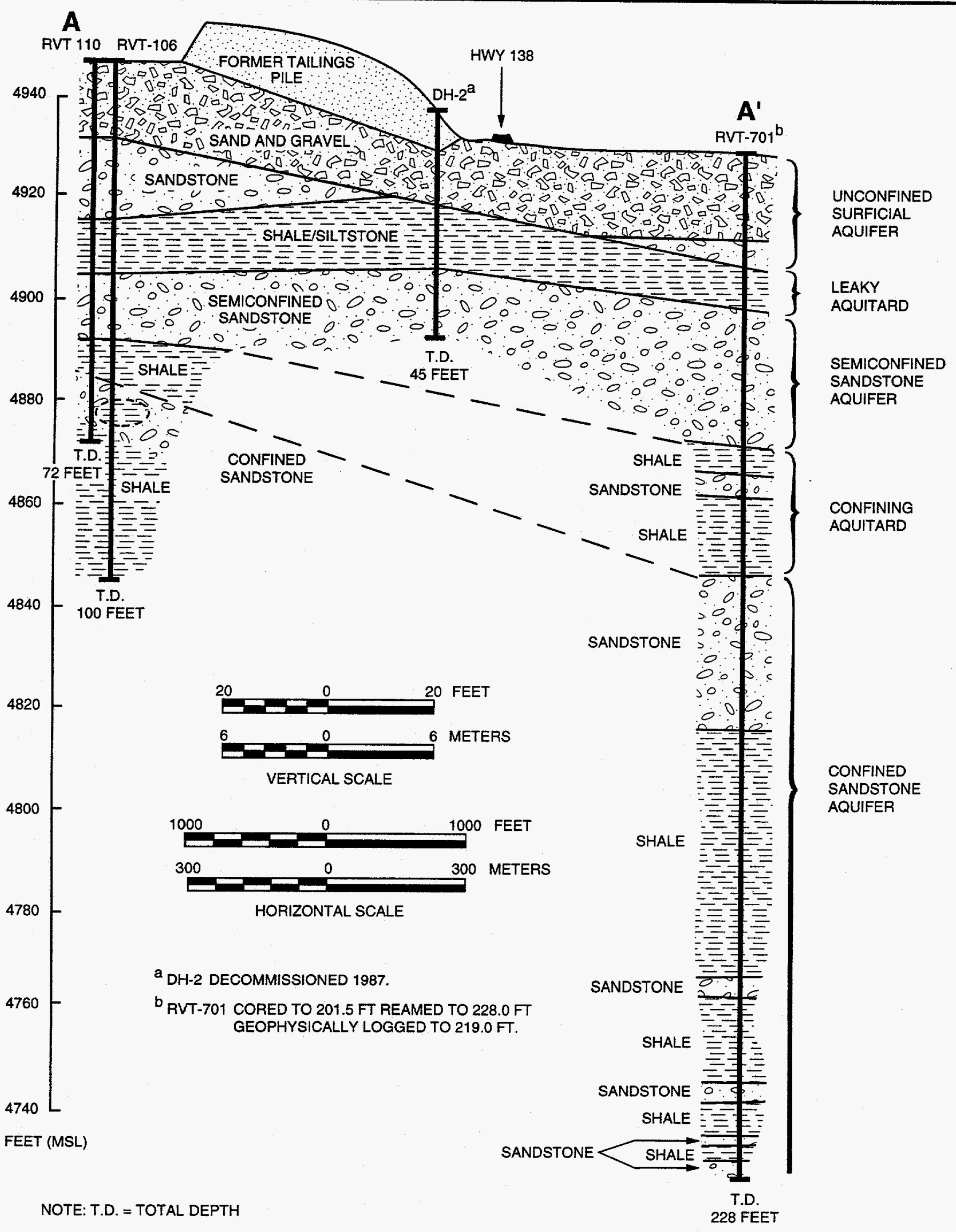

FIGURE 2.3

GEOLOGIC CROSS SECTION RIVERTON, WYOMING, SITE 


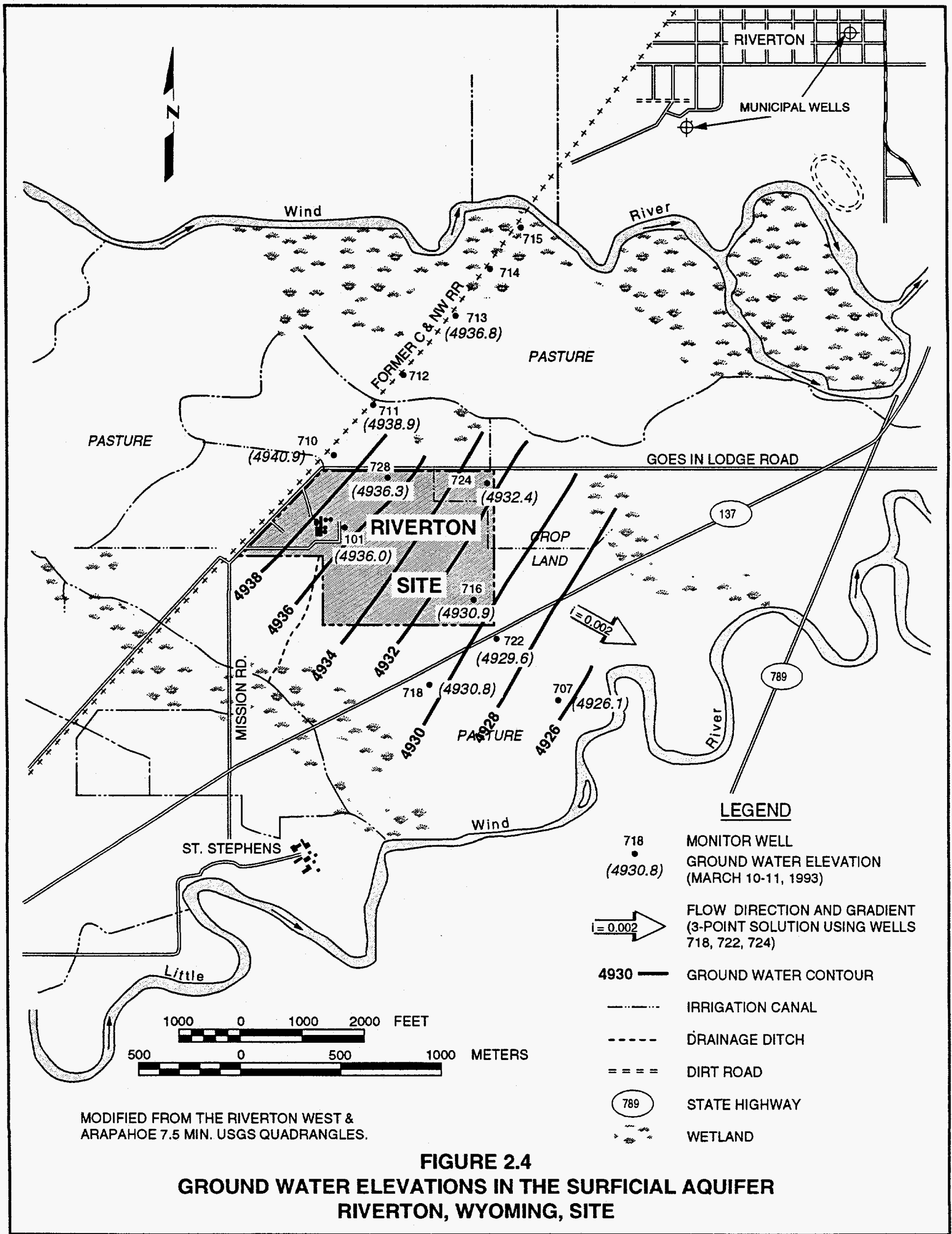


Aquifer tests conducted in the surficial aquifer indicate an average hydraulic conductivity of approximately $56 \mathrm{ft}(17 \mathrm{~m})$ per day. Using an assumed porosity of 0.25 for the alluvium and unconfined sandstone, the calculated ground water flow velocity is approximately $160 \mathrm{ft}(50 \mathrm{~m})$ per year.

\subsubsection{Semiconfined sandstone}

The semiconfined sandstone is continuous throughout the Riverton site. In March 1993, the ground water flow direction in the semiconfined unit was more easterly than in the overlying surficial aquifer (Figure 2.5), but the gradient in the semiconfined sandstone was approximately the same as in the surficial aquifer. At other times of the year, the ground water flows more to the south. In the well cluster northwest and upgradient of the former tailings pile, there was a downward gradient from the surficial aquifer into the semiconfined sandstone, but near the southern and eastern boundaries water elevations in the surficial and semiconfined sandstone wells were nearly identical.

Aquifer tests in the semiconfined sandstone indicate a hydraulic conductivity of about $40 \mathrm{ft}(12 \mathrm{~m})$ per day. Assuming a porosity of 0.15 percent, ground water will move with an approximate velocity of $140 \mathrm{ft}(43 \mathrm{~m})$ per year.

\subsubsection{Confined sandstone}

Water level data from monitor well analyses completed in the confined sandstone near the northwestern corner of the former tailings pile site (RVT 110), at the northeastern corner of the property (RVT 726), and southeast of the site (RVT 709) show that ground water in the confined sandstone flows south with a gradient of approximately 0.002 (Figure 2.6).

These wells also demonstrate an upward gradient from the deep, confined sandstone to the semiconfined sandstone aquifer. This upward gradient will preclude the movement of contaminants from upper aquifers to the confined sandstone or to the deeper aquifers that supply domestic wells in the area.

The piezometric head is higher in the deep wells at both the downgradient location and at the northeast corner of the property. Near the northwest corner of the former tailings pile, the water table elevation in the surficial aquifer is higher than the head in either the semiconfined or the confined sandstones. The lower head in the confined aquifer relative to the surficial aquifer may be caused by pumping from a nearby well to extract water for a sulfuric acid plant near the western edge of the site. This pumping could also cause the more southerly ground water flow calculated in the deep aquifer.

\section{$2.5 \quad$ LAND USE}

Land in the immediate site vicinity is used predominantly for agriculture. Much of the area is pasture for cattle and horses, and the primary crop is hay (DOE, 1987). Several of the residences surrounding the site (Figure 2.7) have 


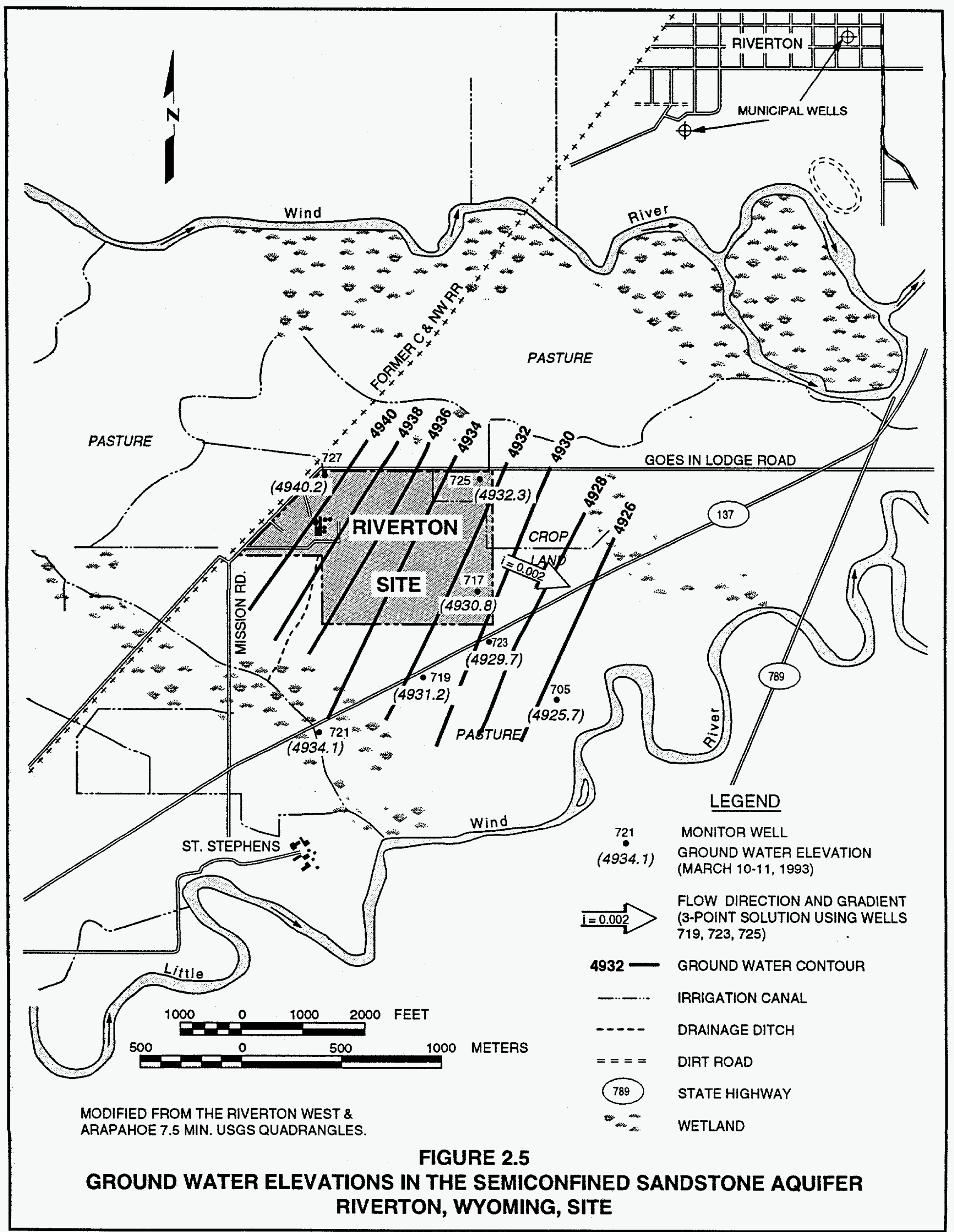




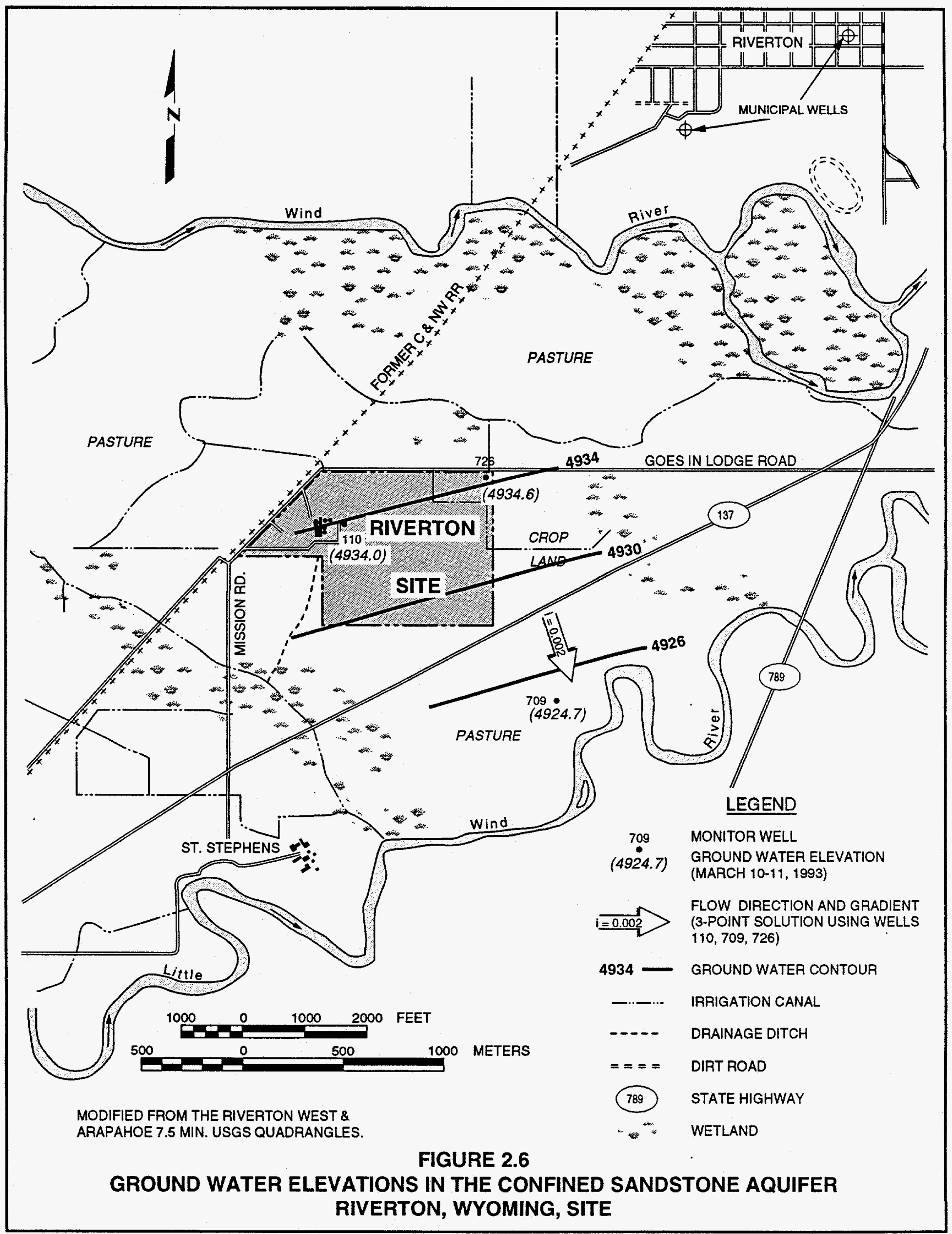




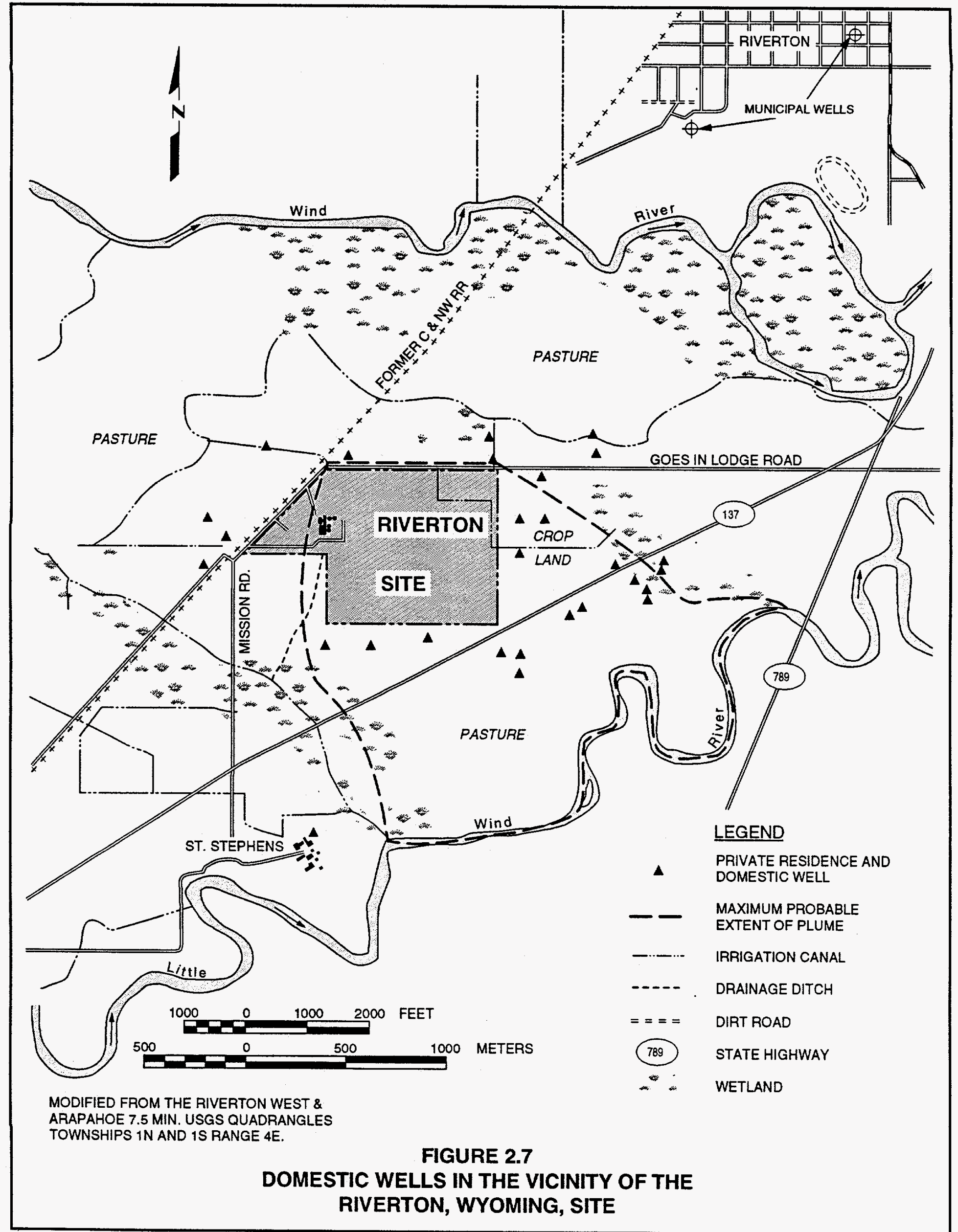


vegetable gardens. The St. Stephens Mission School, a contract school for the Bureau of Indian Affairs (BIA), is $0.6 \mathrm{mi}(0.9 \mathrm{~km})$ south of the site.

The Arapahoe and Shoshone Indian tribes own most of the land surrounding the tailings site, although there are scattered sections of fee land as well (DOE, 1987). Indian tribal lands, administered by the Arapahoe-Shoshone Joint Business Council, and Indian allotted lands, reserved for use by individuals, are also in the site vicinity. Most allottees live on the land rather than leasing it for other purposes (e.g., grazing). A tribal zoning ordinance administered by the Arapahoe-Shoshone Joint Business Council governs area land-use planning and policies and controls all area development.

\subsection{WATER USE}

Door-to-door surveys of the residences near the Riverton processing site were completed in March 1993 and January 1994. Well locations are shown on Figure 2.7; construction details are listed in Table 2.1. Almost all these wells are at depths greater than $100 \mathrm{ft}(30 \mathrm{~m})$, placing them in the first confined sandstone or deeper sandstones.

Water for livestock, agricultural, and domestic use is drawn from wells finished in the confined aquifer. These wells are typically installed by the Indian Health Service at depths greater than $300 \mathrm{ft}(91 \mathrm{~m})$ to reach the higher-quality water from the deeper units. Some residences use well water for drinking; others use bottled water. Two shallow surficial aquifer wells were found that are used to water livestock. Areas near the Riverton processing site are available for future use.

The Wind River is the main source of Riverton municipal water during the spring and summer (April through October). During the fall and winter, the city's only water source is its well system, which taps the confined aquifer of the Wind River Formation. Municipal water is not available to residents near the site. The waters of both the Wind and Little Wind Rivers are used locally for irrigation and livestock watering. 
Table 2.1 Domestic well sampling, construction, and use information, Riverton, Wyoming

\begin{tabular}{|c|c|c|c|c|}
\hline TAC ID & Date sampled & $\begin{array}{c}\text { Total/casing depth } \\
\text { (ft) }\end{array}$ & Aquifer & Water use \\
\hline 405 & $\begin{array}{l}1981,1983,1984(2 x) \\
1985,1990,1991(3 x) \\
1992(2 x), 1993\end{array}$ & $274 / a$ & Confined SS bedrock & Potable \\
\hline 406 & $\begin{array}{l}1981,1990,1991(3 x) \\
1992(2 x), 1993\end{array}$ & $350 / a$ & Confined SS bedrock & Potable \\
\hline 410 & $\begin{array}{l}1982,1983,1984(3 x) \\
1990(2 x), 1992(2 x) \\
1993\end{array}$ & $100 / a$ & Confined SS bedrock & Domestic \\
\hline 411 & $\begin{array}{l}1985,1988,1990 \\
1991(3 x), 1992(2 x) \\
1993\end{array}$ & $270 / 261$ & Confined SS & Domestic \\
\hline 417 & $\begin{array}{l}1981,1990,1991 \\
1992,1993\end{array}$ & $360 / a$ & Confined SS bedrock & Potable $^{a}$ \\
\hline 420 & $\begin{array}{l}1981,1983,1984(3 x) \\
1985,1990(2 x) \\
1991(3 x), 1992(2 x)\end{array}$ & $273 / 228$ & Confined SS bedrock & Potable \\
\hline 421 & 1981,1985 & $200 / a$ & Confined SS bedrock & Potable ${ }^{a}$ \\
\hline 423 & $\begin{array}{l}1984,1985,1988 \\
1990,1991(3 x) \\
1992(2 x), 1993\end{array}$ & $290 / a$ & Confined SS bedrock & Potable \\
\hline 430 & $\begin{array}{l}1981,1983,1984(2 x) \\
1985,1990,1991(2 x) \\
1992(2 x), 1993\end{array}$ & $284 / 320$ & Confined SS bedrock & Potable \\
\hline 431 & $\begin{array}{l}1984,1985,1992 \\
1993\end{array}$ & $\begin{array}{l}\text { approx. } 15 / a \\
\text { (installed with } \\
\text { back-hoe) }\end{array}$ & NA & Stock \\
\hline 436 & $\begin{array}{l}1982,1991(3 x) \\
1992(2 x), 1993\end{array}$ & $525 / a$ & Confined SS bedrock & Potable \\
\hline 440 & $\begin{array}{l}1984,1985(2 x), 1988 \\
1990(2 x)\end{array}$ & $267 / a$ & Confined SS bedrock & Potable ${ }^{a}$ \\
\hline 441 & 1985 & $100 / a$ & Confined SS bedrock & NA \\
\hline 442 & 1994 & $405 / a$ & Confined SS bedrock & Domestic \\
\hline 443 & 1994 & $397 / 356.5$ & Confined SS bedrock & Potable \\
\hline 444 & 1994 & $a / a$ & $\mathbf{a}$ & Unused \\
\hline 445 & 1994 & $35 / a$ & $\begin{array}{l}\text { Semi-confined SS } \\
\text { bedrock }\end{array}$ & Stock \\
\hline
\end{tabular}


Table 2.1 Domestic well sampling, construction, and use information, Riverton, Wyoming (Concluded)

\begin{tabular}{lllll}
\hline TAC ID & \multicolumn{1}{c}{ Date sampled } & \multicolumn{1}{c}{$\begin{array}{c}\text { Total/casing depth } \\
\text { (ft) }\end{array}$} & \multicolumn{1}{c}{ Aquifer } & Water use \\
\hline 446 & 1994 & $410 / 370$ & Confined SS bedrock & Potable \\
448 & 1985 & $405 / \mathrm{a}$ & Confined SS bedrock & Potable \\
451 & 1994 & $360 / 338$ & Confined SS bedrock & Potable \\
452 & 1994 & a & a & Potable \\
453 & 1994 & a & a & Potable \\
460 & 1993 & $450 / a$ & Confined SS bedrock & Process \\
951 & $1988,1992(2 \times)$ & $273 / 246$ & a & Potable \\
NA & No data & a & a & Irrigate \\
\hline
\end{tabular}

Information needs to be collected or confirmed. Where water use is not certain, potable use was assumed.

Note 1: See Figure 2.7 for well locations.

Note 2: Water uses: Potable = Drinking and other uses.

Domestic = Bathing, washing dishes and other uses, but not drinking.

Stock = Watering livestock, irrigation, but not drinking or domestic.

Irrigate $=$ Crop irrigation but no drinking or domestic.

Process $=$ Industrial use.

NA - Not available.

SS - Sandstone. 


\subsection{EXTENT OF CONTAMINATION}

Surface and ground water quality data were collected from 1983 to 1993 at the Riverton site. At present, more than $\mathbf{4 0}$ monitor wells are screened in the three uppermost water-bearing zones in the vicinity of the abandoned mill site. Surface water quality has been monitored from five locations upstream and downstream from the former mill site. Because of improved detection limits and quality control methods, this risk assessment only uses data collected from 1987 to 1993.

Figure 3.1 shows the locations of current monitor wells. The wells that make up the monitor network and their completion information are listed in Table 3.1.

Background water quality is defined as the water quality that could be expected if uranium milling activities had not occurred. Because contamination was detected in the surficial unconfined aquifer and the semiconfined sandstone aquifer, this document discusses background ground water quality for both aquifers. Contamination has not been detected in the confined sandstone aquifer.

\subsubsection{Surficial unconfined aquifer}

Background ground water quality for the surficial unconfined aquifer was determined using ground water reached by monitor wells 710 and 711 . Background locations are north and upgradient from the former processing site (Figure 3.1).

Background ground water quality can be described as a moderately oxidizing, calcium-sulfate-bicarbonate ground water with a slightly basic $\mathrm{pH}$ (7.1 to 7.6). Figure 3.2 shows a trilinear plot of major cation and anion chemistry. Trilinear plots graphically illustrate similarities and/or differences in the water chemistry of samples from different locations. Distributions of cations and anions in samples from related waters plot close together in the two-dimensional fields of the diagrams. The water chemistry plots in Figure 3.2 show similarities in the chemical composition of ground water drawn from monitor wells 710 and 711 . The chemical composition of samples from these wells represents ground water that has not been affected by uranium milling. Table 3.2 presents a statistical summary of surficial aquifer ground water quality, including background water quality.

\subsubsection{Semiconfined aquifer}

Representative background levels for ground water in the semiconfined water-bearing unit were determined by sampling monitor wells 725 and 727 . These wells are upgradient from the remediated tailings pile on the northern 


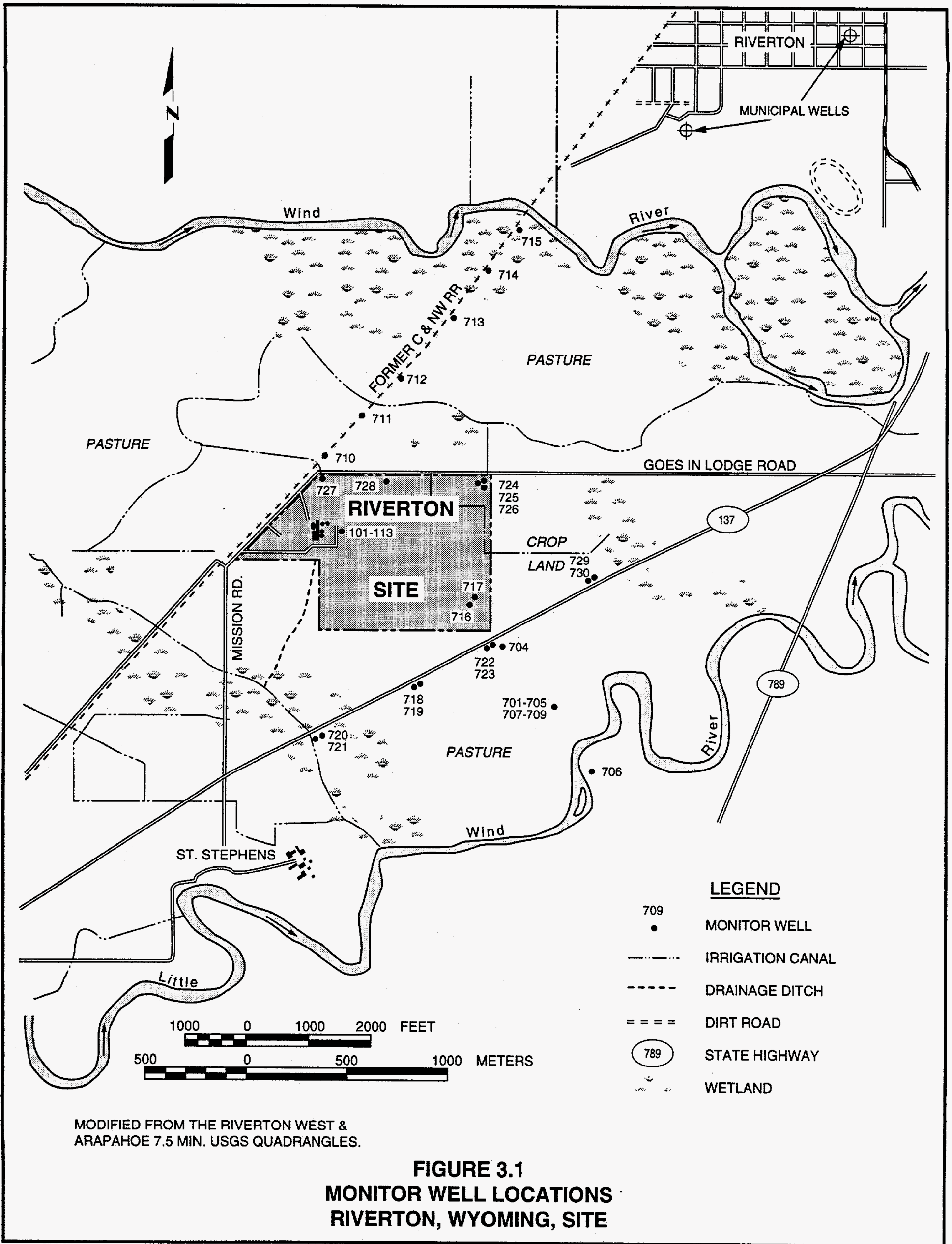


Table 3.1 Ground water monitor well information, Riverton, Wyoming

\begin{tabular}{|c|c|c|c|c|c|c|c|c|}
\hline $\begin{array}{c}\text { Well } \\
\text { 10 }\end{array}$ & $\begin{array}{c}\text { Ground } \\
\text { elevation }\end{array}$ & $\begin{array}{c}\text { Borehole } \\
\text { depth }\end{array}$ & $\begin{array}{l}\text { Borehole } \\
\text { diameter }\end{array}$ & $\begin{array}{c}\text { Casing } \\
\text { elevation }\end{array}$ & $\begin{array}{c}\text { Casing } \\
\text { diameter }\end{array}$ & $\begin{array}{l}\text { Screened } \\
\text { interval }\end{array}$ & $\begin{array}{l}\text { Filter } \\
\text { pack }\end{array}$ & Aquifer \\
\hline 101 & 4946.2 & 17.5 & 6.0 & 4946.58 & 2.0 & $10.5-15.5$ & $5.5-17.5$ & Surficial \\
\hline 104 & 4945.3 & 15.5 & 6.3 & 4945.90 & 2.0 & $8.5-13.5$ & $6.5-15.5$ & Surficial \\
\hline 108 & 4946.2 & 56.0 & 6.0 & 4946.02 & 2.0 & $48.5-53.5$ & $35.5-56.5$ & Semiconfined SS \\
\hline 110 & 4946.2 & 72.0 & 6.0 & 4946.44 & 2.0 & $61.3-66.5$ & $59.0-72.0$ & Confined SS \\
\hline 705 & 4930.1 & 50.0 & 10.0 & 4930.80 & 6.0 & $38.0-48.0$ & $35.5-50.0$ & Semiconfined SS \\
\hline 706 & 4931.1 & 21.5 & 6.0 & 4932.00 & 2.0 & $14.5-19.5$ & $12.8-21.5$ & Surficial \\
\hline 707 & 4930.4 & 18.0 & 6.0 & 4931.00 & 2.0 & $9.8-14.8$ & $7.5-16.8$ & Surficial \\
\hline 709 & 4930.2 & 111.0 & 10.0 & 4930.70 & 6.0 & $85.0-105.0$ & $84.0-111.0$ & Confined SS \\
\hline 710 & 4947.2 & 20.0 & 6.0 & 4947.90 & 2.0 & $11.2-16.2$ & $8.0-20.0$ & Surficial \\
\hline 711 & 4943.5 & 21.5 & 6.0 & 4944.50 & 2.0 & $10.8-15.8$ & $6.0-21.5$ & Surficial \\
\hline 712 & 4943.5 & 19.5 & 6.0 & 4944.50 & 2.0 & $10.6-15.6$ & $10.0-19.5$ & Surficial \\
\hline 716 & 4936.4 & 12.5 & 6.0 & 4939.12 & 2.0 & $7.5-12.5$ & 5.5-12.5 & Surficial \\
\hline 717 & 4936.4 & 50.0 & 6.0 & 4938.80 & 2.0 & $37.5-47.5$ & $29.0-49.5$ & Semiconfined SS \\
\hline 718 & 4937.0 & 18.0 & 6.0 & 4937.18 & 2.0 & $13.0-18.0$ & $10.0-18.0$ & Surficial \\
\hline 719 & 4936.8 & 40.0 & 6.0 & 4936.94 & 2.0 & $28.0-38.0$ & $23.0-40.0$ & Semiconfined SS \\
\hline 720 & 4937.9 & 10.5 & 6.0 & 4940.46 & 2.0 & $5.5-10.5$ & $3.5-10.5$ & Surficial \\
\hline 721 & 4937.9 & 49.0 & 6.0 & 4940.47 & 2.0 & $37.0-47.0$ & $27.0-49.0$ & Semiconfined SS \\
\hline 722 & 4935.2 & 18.0 & 6.0 & 4935.35 & 2.0 & $6.0-16.0$ & $4.0-18.0$ & Surficial \\
\hline 723 & 4935.0 & 49.0 & 6.0 & 4935.26 & 2.0 & $35.5-45.5$ & $31.0-47.5$ & Semiconfined SS \\
\hline 724 & 4939.4 & 16.0 & 6.0 & 4941.36 & 2.0 & $11.0-16.0$ & $6.0-16.0$ & Surficial \\
\hline 725 & 4939.4 & 38.0 & 6.0 & 4941.36 & 2.0 & $24.5-34.5$ & $19.5-36.5$ & Semiconfined SS \\
\hline 726 & 4939.5 & 133.0 & 6.0 & 4942.00 & 2.0 & $121.0-131$ & $80.0-133.0$ & Confined SS \\
\hline 727 & 4949.5 & 40.0 & 6.0 & 4951.69 & 2.0 & $27.0-37.0$ & $21.5-39.0$ & Semiconfined SS \\
\hline 728 & 4943.9 & 24.0 & 6.0 & 4946.01 & 2.0 & $12.0-22.0$ & $9.0-24.0$ & Surficial \\
\hline 729 & 4932.1 & 17.0 & 6.0 & 4932.07 & 2.0 & $9.0-14.0$ & $8.0-14.0$ & Surficial \\
\hline 730 & 4932.5 & 40.0 & 6.0 & 4932.48 & 2.0 & $28.0-38.0$ & $21.0-40.0$ & Semiconfined SS \\
\hline
\end{tabular}

NOTE: Elevations in feet relative to mean sea level (MSL); depths in feet; diameters in inches.

SS - sandstone. 


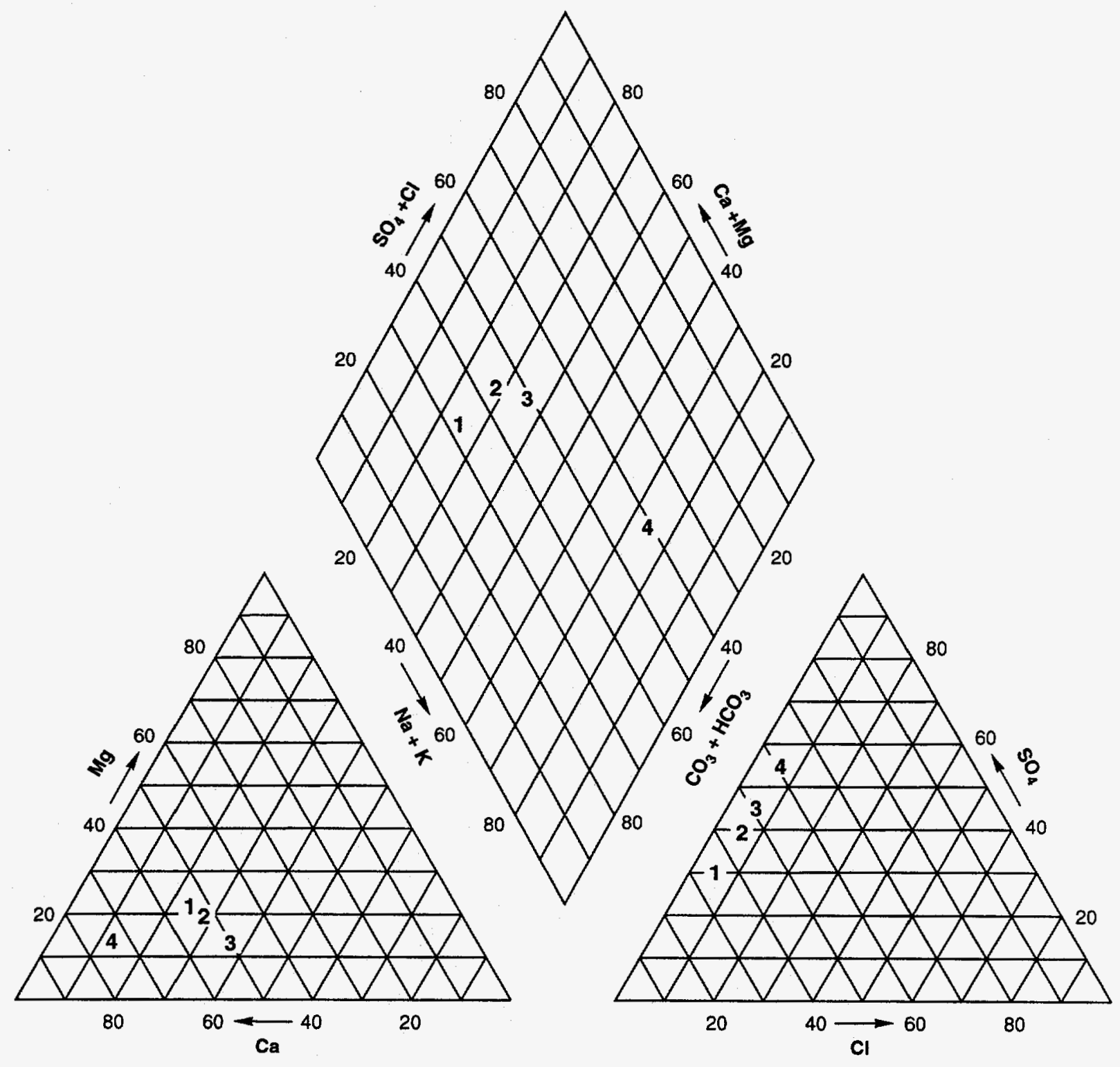

Cations

Anions

$\%$ of total MEQ/L

(4 samples)

NOTES:

1. UPGRADIENT ALLUVIAL AQUIFER: MONITOR WELLS 710 AND 711.

LEGEND

2. SEMICONFINED AQUIFER: MONIOR WELLS 725 AND 727.

3. WATER QUALITY DATE: MARCH 1993.

1 MONITOR WELL 710

2 MONITOR WELL 711

3 MONITOR WELL 725

4 MONITOR WELL 727

FIGURE 3.2

TRILINEAR PLOT OF COMPOSITION OF BACKGROUND GROUND WATER RIVERTON, WYOMING, SITE 


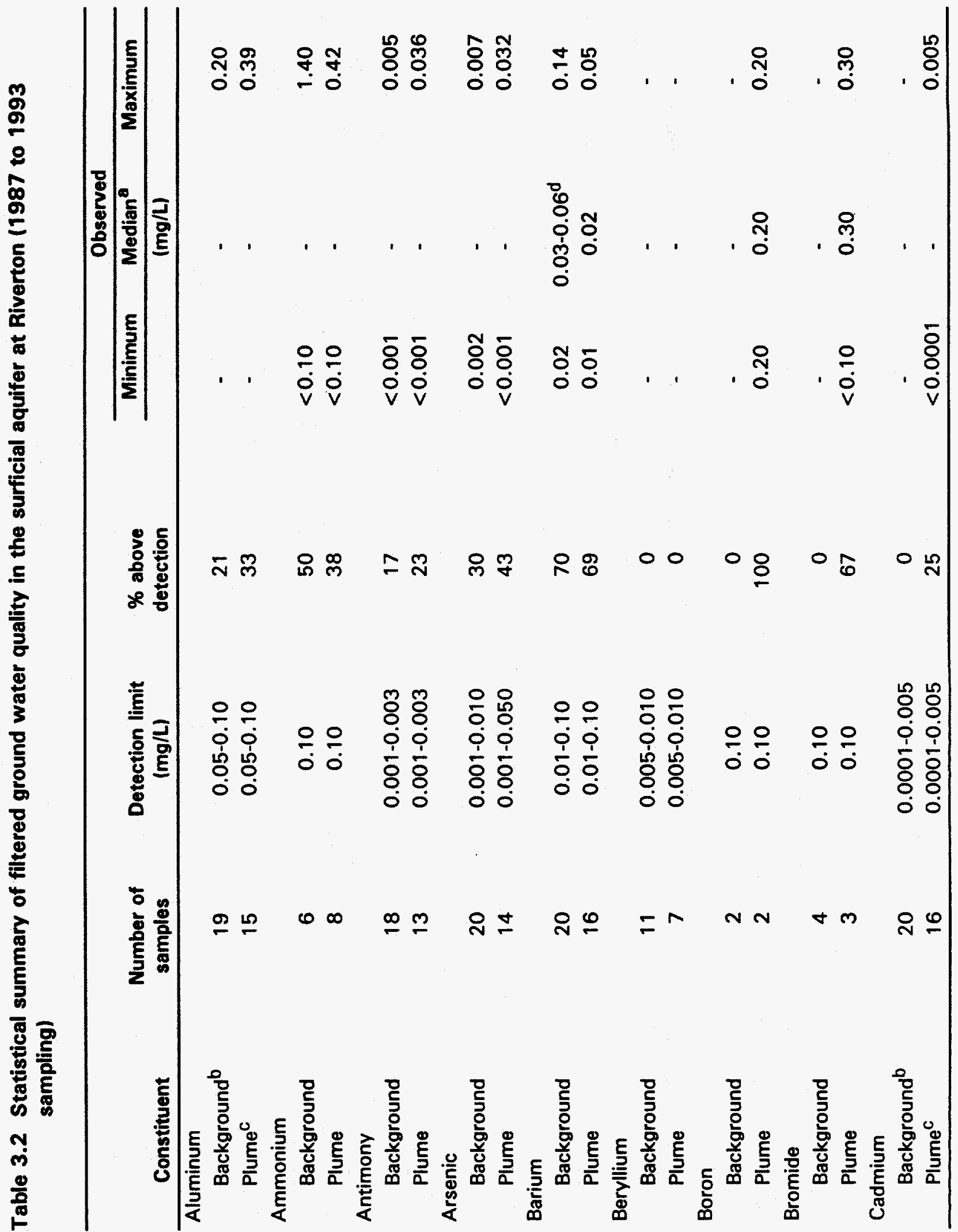




\begin{tabular}{|c|c|c|c|c|c|c|c|}
\hline \multirow{4}{*}{ 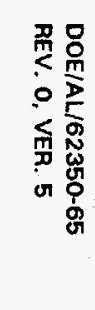 } & \multicolumn{7}{|c|}{$\begin{aligned} \text { Table } 3.2 & \begin{array}{l}\text { Statistical summary o } \\
\text { sampling) (Continued) }\end{array}\end{aligned}$} \\
\hline & \multirow[b]{3}{*}{ Constituent } & \multirow{3}{*}{$\begin{array}{l}\text { Number of } \\
\text { samples }\end{array}$} & \multirow{3}{*}{$\begin{array}{c}\text { Detection limit } \\
\text { (mg/L) }\end{array}$} & \multirow{3}{*}{$\begin{array}{l}\% \text { above } \\
\text { detection }\end{array}$} & \multicolumn{3}{|c|}{ Observed } \\
\hline & & & & & Minimum & Median $^{8}$ & Maximum \\
\hline & & & & & & (mg/L) & \\
\hline & \multicolumn{7}{|l|}{ Calcium } \\
\hline & Background & 20 & $0.01-1.00$ & 100 & 53.2 & 71.7 & 271 \\
\hline & Plume & 16 & $0.01-1.00$ & 100 & 345 & 403 & 605 \\
\hline & \multicolumn{7}{|l|}{ Chloride } \\
\hline & Background & 20 & $0.50-1.00$ & 100 & 4.50 & 11.2 & 125 \\
\hline & Plume & 16 & $0.50-1.00$ & 100 & 85.0 & 118 & 207 \\
\hline & \multicolumn{7}{|l|}{ Chromium } \\
\hline & Background & 20 & 0.01 & 5 & $<0.01$ & - & 0.06 \\
\hline & Plume & 16 & 0.01 & 13 & $<0.01$ & - & 0.13 \\
\hline & \multicolumn{7}{|l|}{ Cobalt } \\
\hline & Background & 12 & $0.03-0.05$ & 0 & - & - & - \\
\hline & Plume & 8 & $0.03-0.05$ & 0 & - & - & - \\
\hline & \multicolumn{7}{|l|}{ Copper } \\
\hline & Background & 16 & $0.01-0.02$ & 0 & - & - & - \\
\hline & Plume & 14 & $0.01-0.02$ & 21 & $<0.01$ & - & 0.02 \\
\hline & \multicolumn{7}{|l|}{ Cyanide } \\
\hline & Background & 6 & 0.01 & 0 & - & - & - \\
\hline & Plume & 5 & 0.01 & 0 & - & - & - \\
\hline & \multicolumn{7}{|l|}{ Fluoride } \\
\hline & Background & 16 & 0.10 & 88 & $<0.10$ & 0.20 & 0.40 \\
\hline & Plume & 10 & $0.10-1.00$ & 90 & 0.70 & 0.80 & 1.00 \\
\hline & \multicolumn{7}{|l|}{ Iron } \\
\hline 量 & Background $^{b}$ & 20 & $0.02-0.03$ & 75 & $<0.03$ & 0.10 & 1.56 \\
\hline$\sum_{\substack{n \\
m}}^{m}$ & Plume ${ }^{c}$ & 16 & $0.02-0.03$ & 100 & 0.04 & 0.20 & 3.05 \\
\hline $\begin{array}{l}\text { s: } \\
8 \\
8\end{array}$ & \multicolumn{7}{|l|}{ Lead } \\
\hline$\vec{g} \vec{N}$ & Background & 20 & $0.001-0.010$ & 10 & $<0.001$ & - & 0.004 \\
\hline$\sum \overrightarrow{0}$ & Plume & 16 & $0.001-0.030$ & 38 & $<0.001$ & - & 0.020 \\
\hline
\end{tabular}




\begin{tabular}{|c|c|c|c|c|c|c|c|}
\hline \multirow{4}{*}{ 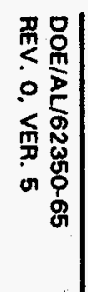 } & $\begin{array}{rr}\text { Table } 3.2 & \text { St } \\
& \text { sar }\end{array}$ & \multicolumn{6}{|c|}{$\begin{array}{l}\text { Statistical summary of } \\
\text { sampling) (Continued) }\end{array}$} \\
\hline & \multirow[b]{3}{*}{ Constituent } & \multirow{3}{*}{$\begin{array}{l}\text { Number of } \\
\text { samples }\end{array}$} & \multirow{3}{*}{$\begin{array}{l}\text { Detection limit } \\
\text { (mg/L) }\end{array}$} & \multirow{3}{*}{$\begin{array}{l}\% \text { above } \\
\text { detection }\end{array}$} & \multicolumn{3}{|c|}{ Observed } \\
\hline & & & & & Minimum & Median" & Maximum \\
\hline & & & & & & (mg/L) & \\
\hline & \multicolumn{7}{|l|}{ Magnesium } \\
\hline & Background & 20 & $0.001-1.00$ & 100 & 13.6 & 17.3 & 68.0 \\
\hline & Plume & 16 & $0.001-1.00$ & 100 & 179 & 198 & 291 \\
\hline & \multicolumn{7}{|l|}{ Manganese } \\
\hline & Background & 20 & 0.01 & 75 & $<0.01$ & 0.70 & 3.56 \\
\hline & Plume & 16 & 0.01 & 100 & 4.26 & 4.78 & 6.40 \\
\hline & \multicolumn{7}{|l|}{ Mercury } \\
\hline & Background & 16 & $0.0001-0.0002$ & 6 & $<0.0001$ & - & 0.0004 \\
\hline & Plume & 13 & $0.0001-0.0002$ & 8 & $<0.0001$ & - & 0.0004 \\
\hline & \multicolumn{7}{|l|}{ Molybdenum } \\
\hline & Background & 20 & $0.001-0.010$ & 25 & 0.003 & - & 0.020 \\
\hline & Plume & 16 & $0.001-0.010$ & 100 & 0.52 & 0.78 & 1.02 \\
\hline & \multicolumn{7}{|l|}{ Nickel } \\
\hline & Background & 20 & $0.01-0.04$ & 10 & $<0.01$ & - & 0.03 \\
\hline & Plume & 16 & $0.01-0.04$ & 94 & $<0.04$ & 0.17 & 0.28 \\
\hline & \multicolumn{7}{|l|}{ Nitrate } \\
\hline & Background ${ }^{b}$ & 16 & $0.10-1.00$ & 56 & $<0.10$ & $0.15-1.0^{d}$ & 7.10 \\
\hline & Plume ${ }^{c}$ & 14 & $0.10-1.00$ & 57 & $<0.10$ & $0.25-0.95^{d}$ & 8.40 \\
\hline & \multicolumn{7}{|l|}{ Phosphate } \\
\hline & Background & 6 & 0.10 & 50 & $<0.10$ & - & 0.30 \\
\hline & Plume & 8 & 0.10 & 50 & $<0.10$ & - & 1.80 \\
\hline & \multicolumn{7}{|l|}{ Potassium } \\
\hline 吕 & Background & 20 & $0.01-0.50$ & 100 & 1.86 & 2.50 & 6.40 \\
\hline 涩变 & Plume & 16 & $0.01-0.50$ & 100 & 10.4 & 14.5 & 18.0 \\
\hline 䍃 & \multicolumn{7}{|l|}{ Selenium } \\
\hline 造 & Background & 18 & $0.001-0.005$ & 6 & $<0.001$ & - & 0.005 \\
\hline $\overrightarrow{8}$ & Plume & 14 & $0.001-0.030$ & 43 & $<0.001$ & - & 0.077 \\
\hline
\end{tabular}




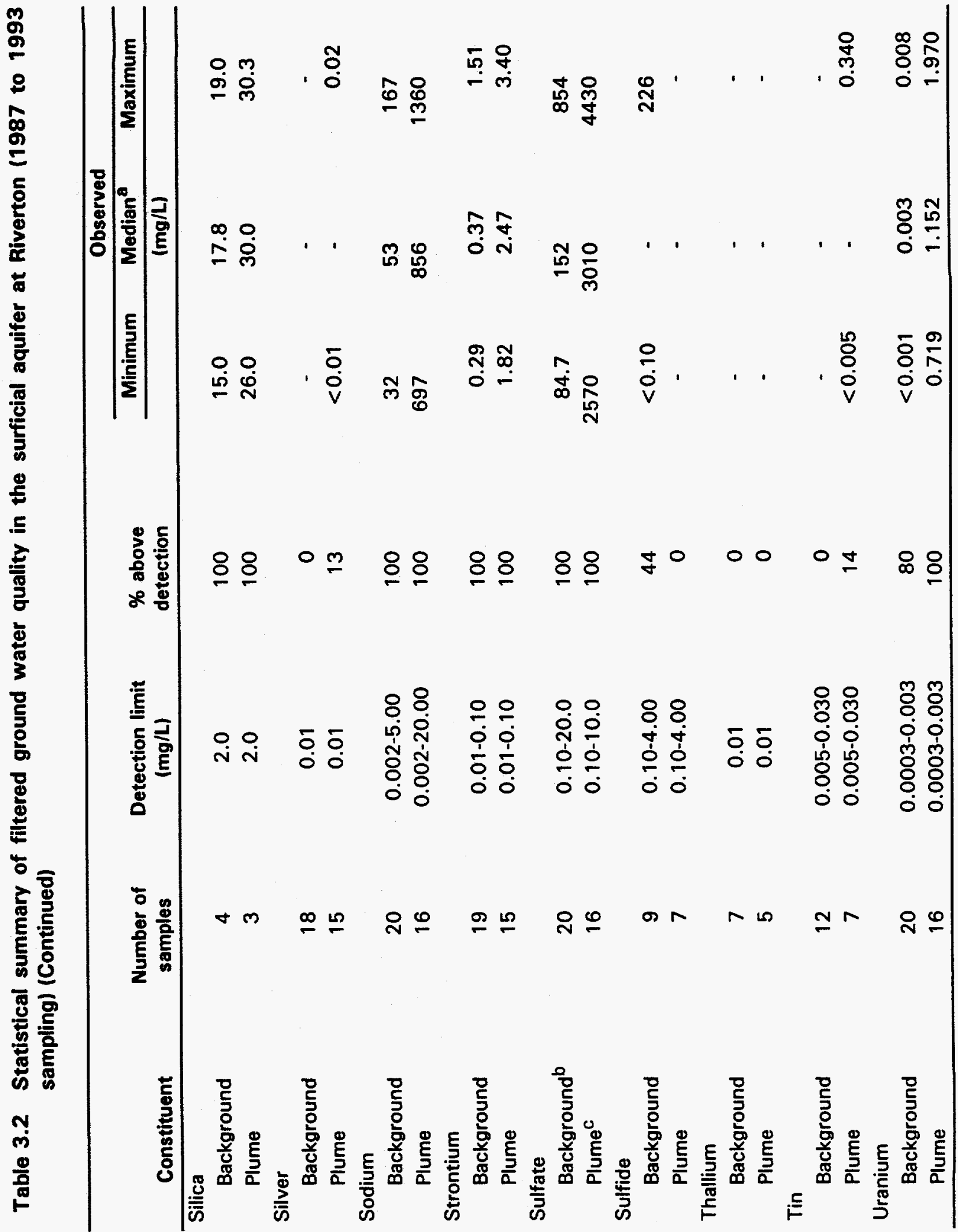




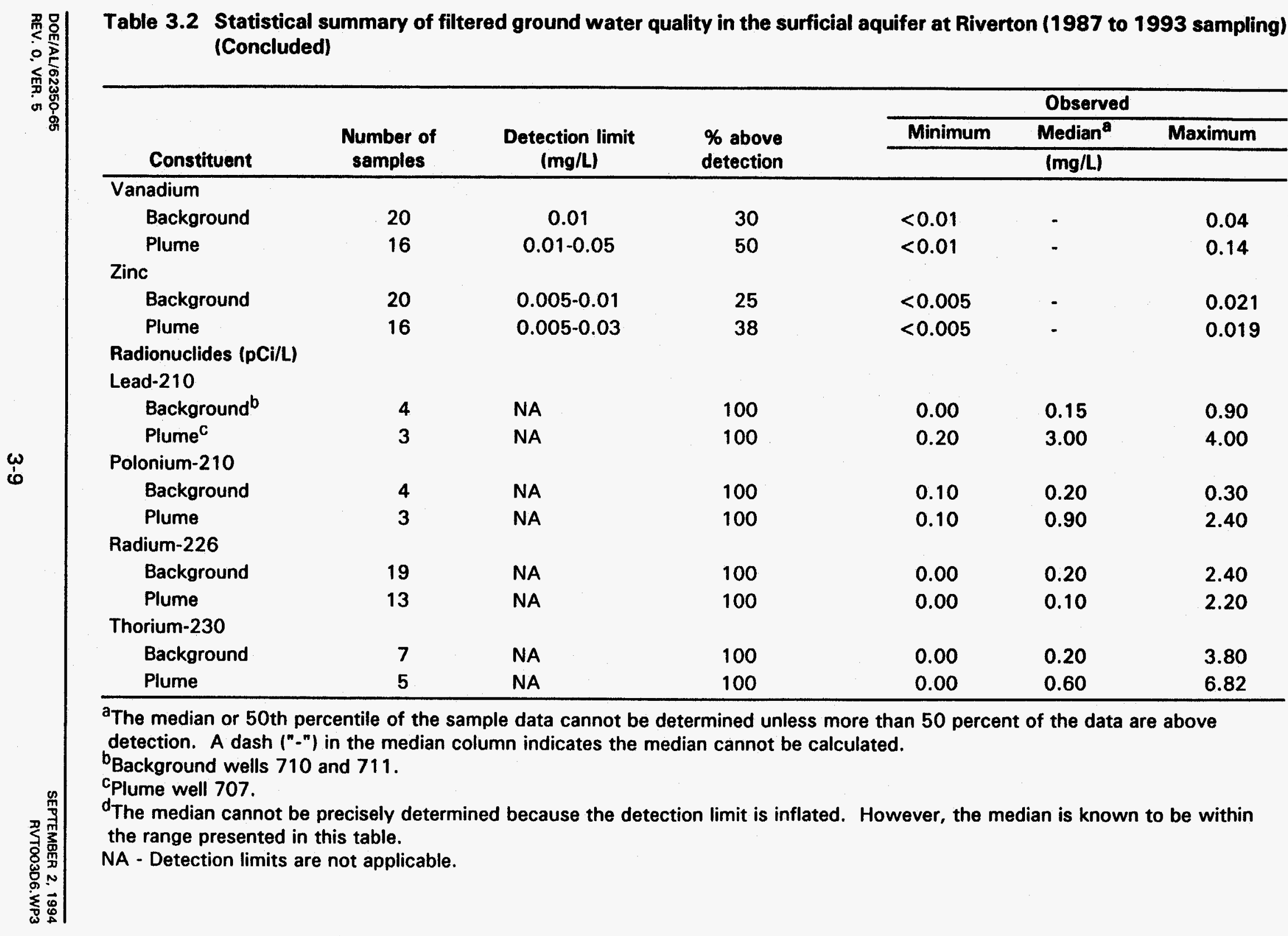


perimeter of the site boundary. Table 3.3 summarizes water quality data for the semiconfined aquifer from the March 1993 sampling round.

Background ground water quality in the semiconfined aquifer can be described as a moderately oxidizing, sulfate-bicarbonate-calcium sodium type with a slightly basic pH. Figure 3.2 shows that calcium and bicarbonate are the dominant cation and anion in monitor well 725 but sodium and sulfate are the predominant cation and anion in monitor well 727. This variability is difficult to explain; only one sampling round precludes the use of statistical analysis. Ground water accessed from these wells probably represents background chemistry for the semiconfined aquifer.

\section{MAGNITUDE OF SITE-RELATED CONTAMINATION}

Ground water in both the surficial and semiconfined aquifers appears to be affected by milling activities. Ground water is impacted to a greater extent in the surficial aquifer than the semiconfined aquifer because of the greater intimacy between ground water in the surficial aquifer and tailings leachate that had drained into underlying soils. The magnitude of contamination present in both aquifers is discussed below.

\subsubsection{Surficial aquifer}

Ground water in the surficial aquifer downgradient from the abandoned processing site is characterized by elevated total dissolved solids (TDS) and other constituents associated with uranium milling (e.g., uranium, molybdenum, and sulfate). Isopleths denoting the concentrations of uranium, molybdenum, and sulfate in ground water sampled from the surficial aquifer are shown in Figures 3.3 through 3.5. From the concentration isopleth maps, contamination appears to be migrating to the southeast. Calculating from historical ground water levels, ground water flows southeast (135 degrees), plus or minus 25 degrees. This direction coincides with the historical contaminant trail.

Samples from monitor well 707 represent ground water with the greatest concentrations of contaminants in the surficial aquifer (Table 3.2). Water quality data are available from 1985 to 1993 . This well is approximately 2000 $\mathrm{ft}(600 \mathrm{~m})$ southeast of the southeast corner of the site boundary. Presently, the center of the plume appears to be in the vicinity of monitor well 707 , traveling less than half the calculated linear velocity of ground water $(165 \mathrm{ft}$ [50 $\mathrm{m}$ ] per year). This difference occurs because the interaction between contaminants and the aquifer matrix retards contaminants at different rates as they travel through the aquifer. This phenomenon contributes to different contaminant plume shapes and positions with respect to linear ground water flow.

To generate a list of hazardous constituents related to milling activities, water quality data from monitor well 707 were statistically compared to background ground water quality data from monitor wells 710 and 711 . Water quality data 
Table 3.3 Summary of filtered ground water quality for the contaminants of concern in the semiconfined aquifer at Riverton (1993 sampling)

\begin{tabular}{|c|c|c|}
\hline Constituent $^{a}$ & Range & Median' \\
\hline \multicolumn{3}{|l|}{ Inorganics (mg/L) } \\
\hline \multicolumn{3}{|l|}{ Aluminum } \\
\hline Background & $<0.05$ & - \\
\hline Downgradient & $<0.05$ & - \\
\hline \multicolumn{3}{|l|}{ Arsenic } \\
\hline Background & $<0.005$ & - \\
\hline Downgradient & $<0.005$ & - \\
\hline \multicolumn{3}{|l|}{ Barium. } \\
\hline Background & $<0.1$ & - \\
\hline Downgradient & $<0.1$ & - \\
\hline \multicolumn{3}{|l|}{ Bromide } \\
\hline Background & $<0.1-0.1$ & $<0.1$ \\
\hline Downgradient & $<0.1-0.28$ & 0.2 \\
\hline \multicolumn{3}{|l|}{ Cadmium } \\
\hline Background & $<0.001$ & - \\
\hline Downgradient & $<0.001$ & - \\
\hline \multicolumn{3}{|l|}{ Calcium } \\
\hline Background & $30-98$ & 64 \\
\hline Downgradient & $106-401$ & 181 \\
\hline \multicolumn{3}{|l|}{ Chloride } \\
\hline Background & $16-20$ & 18 \\
\hline Downgradient & $55-73$ & 61 \\
\hline \multicolumn{3}{|l|}{ Chromium } \\
\hline Background & $<0.01$ & - \\
\hline Downgradient & $<0.01$ & - \\
\hline \multicolumn{3}{|l|}{ Fluoride } \\
\hline Background & 0.2 & 0.2 \\
\hline Downgradient & $0.1-0.2$ & 0.2 \\
\hline \multicolumn{3}{|l|}{ Iron } \\
\hline Background & $<0.03-0.04$ & $<0.04$ \\
\hline Downgradient & $<0.03-0.39$ & 0.16 \\
\hline
\end{tabular}


Table 3.3 Summary of filtered ground water quality for the contaminants of concern in the semiconfined aquifer at Riverton (1993 sampling) (Continued)

\begin{tabular}{|c|c|c|}
\hline Constituent $^{a}$ & Range & Median $^{\mathbf{b}}$ \\
\hline \multicolumn{3}{|c|}{ Inorganics (mg/L) (continued) } \\
\hline \multicolumn{3}{|l|}{ Lead } \\
\hline Background & $<0.003$ & - \\
\hline Downgradient & $<0.003$ & - \\
\hline \multicolumn{3}{|l|}{ Magnesium } \\
\hline Background & $2.8-17$ & 10 \\
\hline Downgradient & $7.5-32$ & 13 \\
\hline \multicolumn{3}{|l|}{ Manganese } \\
\hline Background & $0.02-0.06$ & 0.04 \\
\hline Downgradient & $0.13-0.91$ & 0.26 \\
\hline \multicolumn{3}{|l|}{ Molybdenum } \\
\hline Background & $<0.01$ & - \\
\hline Downgradient & $<0.01-1.27$ & 0.03 \\
\hline \multicolumn{3}{|l|}{ Nickel } \\
\hline Background & $<0.04$ & - \\
\hline Downgradient & $<0.04$ & - \\
\hline \multicolumn{3}{|l|}{ Potassium } \\
\hline Background & $1.0-1.3$ & 1.2 \\
\hline Downgradient & $1.2-2.7$ & 1.9 \\
\hline \multicolumn{3}{|l|}{ Selenium } \\
\hline Background & $<0.005$ & - \\
\hline Downgradient & $<0.005$ & - \\
\hline \multicolumn{3}{|l|}{ Sodium } \\
\hline Background & $79-118$ & 99 \\
\hline Downgradient & $108-665$ & 288 \\
\hline \multicolumn{3}{|l|}{ Strontium } \\
\hline Background & $0.2-0.5$ & 0.3 \\
\hline Downgradient & $0.6-2.7$ & 0.9 \\
\hline
\end{tabular}


Table 3.3 Summary of filtered ground water quality for the contaminants of concern in the semiconfined aquifer at Riverton (1993 sampling) (Concluded)

\begin{tabular}{|c|c|c|}
\hline Constituent $^{\mathbf{a}}$ & Range & Median $^{\mathbf{b}}$ \\
\hline \multicolumn{3}{|c|}{ Inorganics (mg/L) (concluded) } \\
\hline \multicolumn{3}{|l|}{ Sulfate } \\
\hline Background & $170-207$ & 189 \\
\hline Downgradient & $592-1860$ & 686 \\
\hline \multicolumn{3}{|l|}{ Uranium } \\
\hline Background & $0.002-0.008$ & 0.005 \\
\hline Downgradient & $0.002-0.017$ & 0.011 \\
\hline \multicolumn{3}{|l|}{ Vanadium } \\
\hline Background & $<0.01$ & - \\
\hline Downgradient & $<0.01$ & - \\
\hline \multicolumn{3}{|l|}{ Zinc } \\
\hline Background & $0.008-0.012$ & 0.010 \\
\hline Downgradient & $0.008-0.013$ & 0.010 \\
\hline \multicolumn{3}{|l|}{ Radionuclides (pCi/L) } \\
\hline \multicolumn{3}{|l|}{ Lead-210 } \\
\hline Background & $0.3-1.5$ & 0.9 \\
\hline Downgradient & $0.0-1.5$ & 0.7 \\
\hline \multicolumn{3}{|l|}{ Polonium-210 } \\
\hline Background & 0.0 & 0.0 \\
\hline Downgradient & $0.0-0.6$ & 0.1 \\
\hline \multicolumn{3}{|l|}{ Radium-226 } \\
\hline Background & $0.0-0.8$ & 0.4 \\
\hline Downgradient & $0.0-4.0$ & 0.9 \\
\hline \multicolumn{3}{|l|}{ Thorium-230 } \\
\hline Background & $0.1-1.6$ & 0.9 \\
\hline Downgradient & $0.0-0.6$ & 0.2 \\
\hline
\end{tabular}

${ }^{a}$ Background, defined by monitor wells 725 and 727 , consist of two data values for each constituent listed. Downgradient wells 108, 717, 719, and 723 provide four data values for each constituent listed.

${ }^{b}$ The median is the 50th percentile of the data. Based on two data values, the median is only the arithmetic average. For four data values, the median is the average of the two middle values.

A dash $("-n)$ in the median column indicates the median cannot be calculated. 


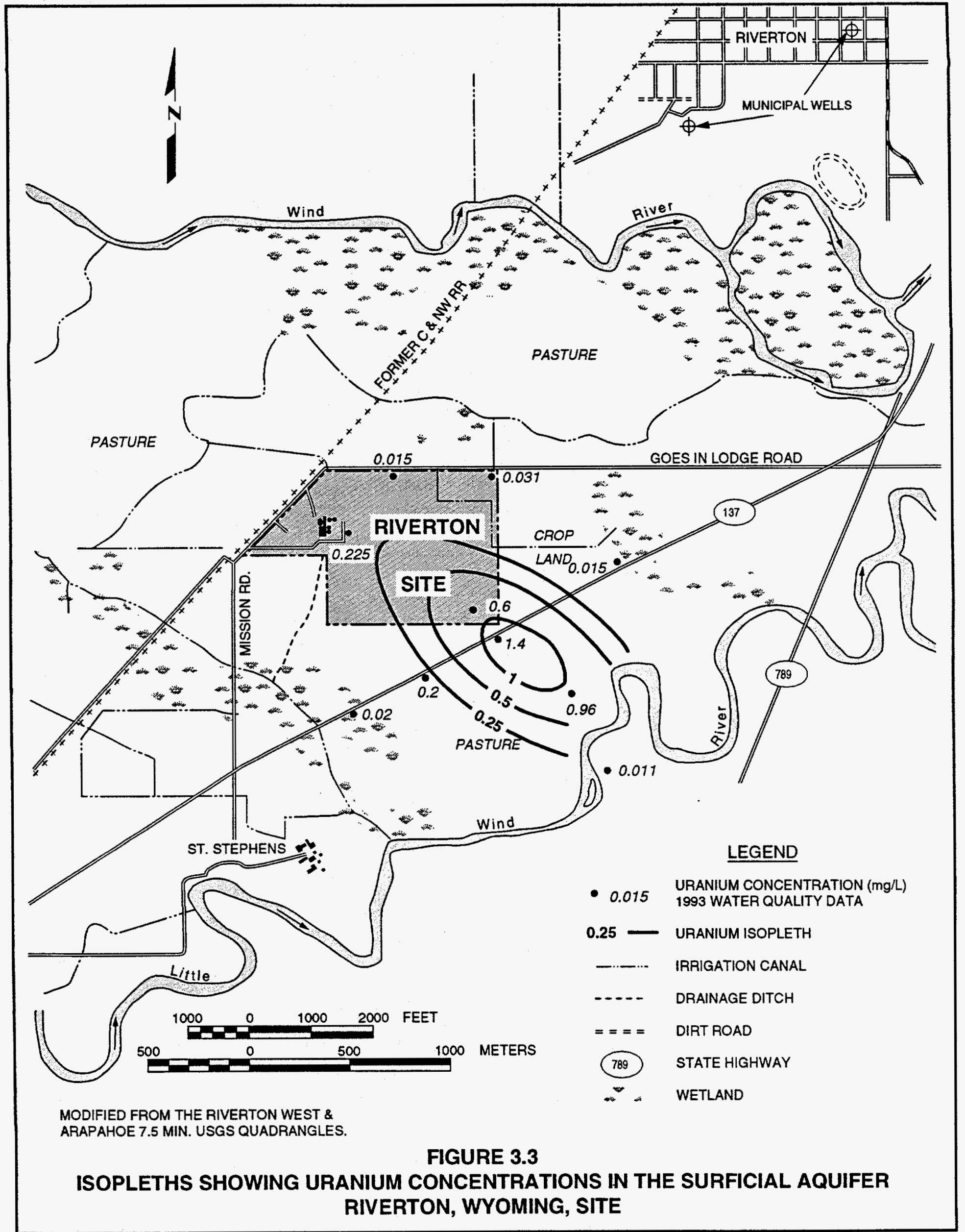




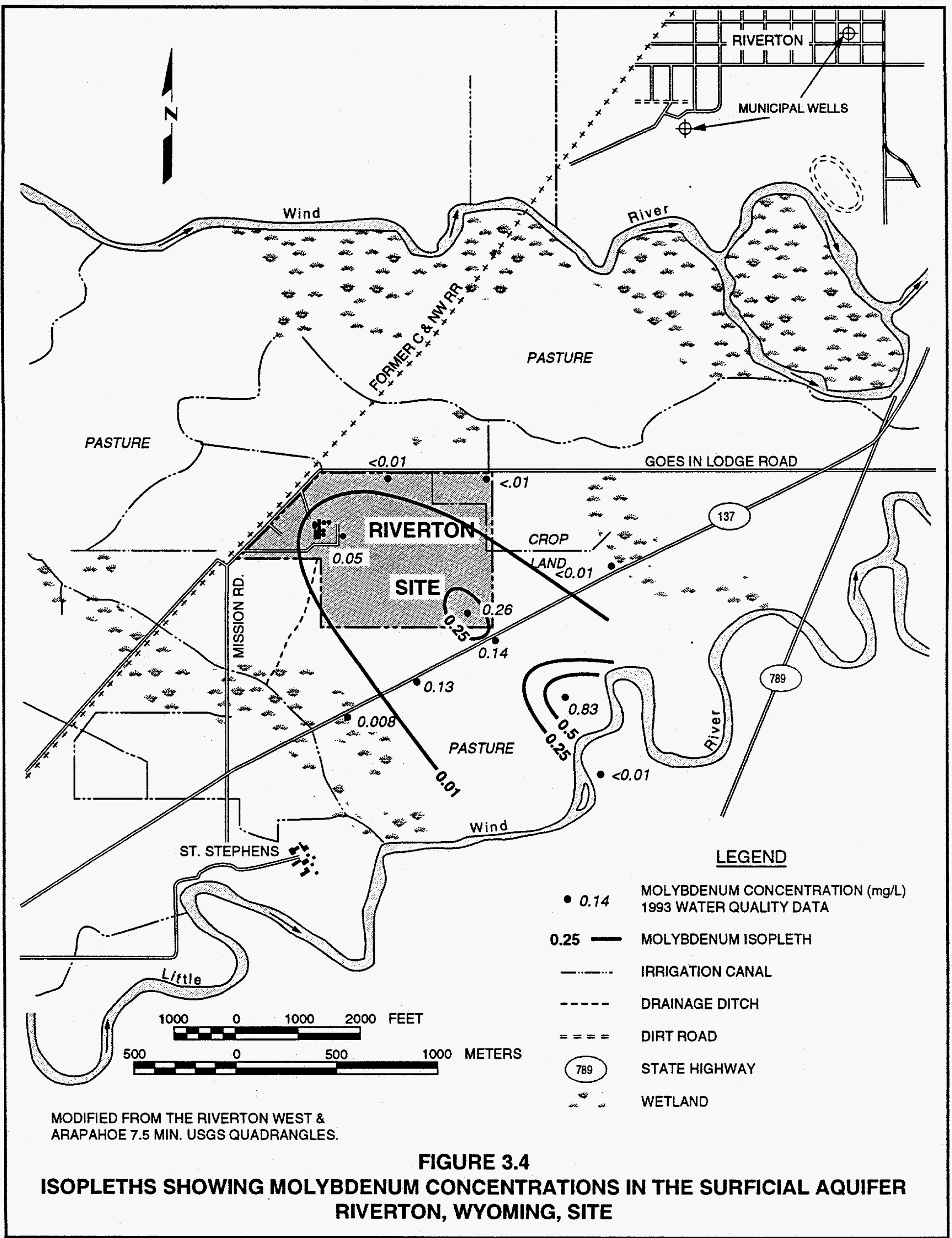




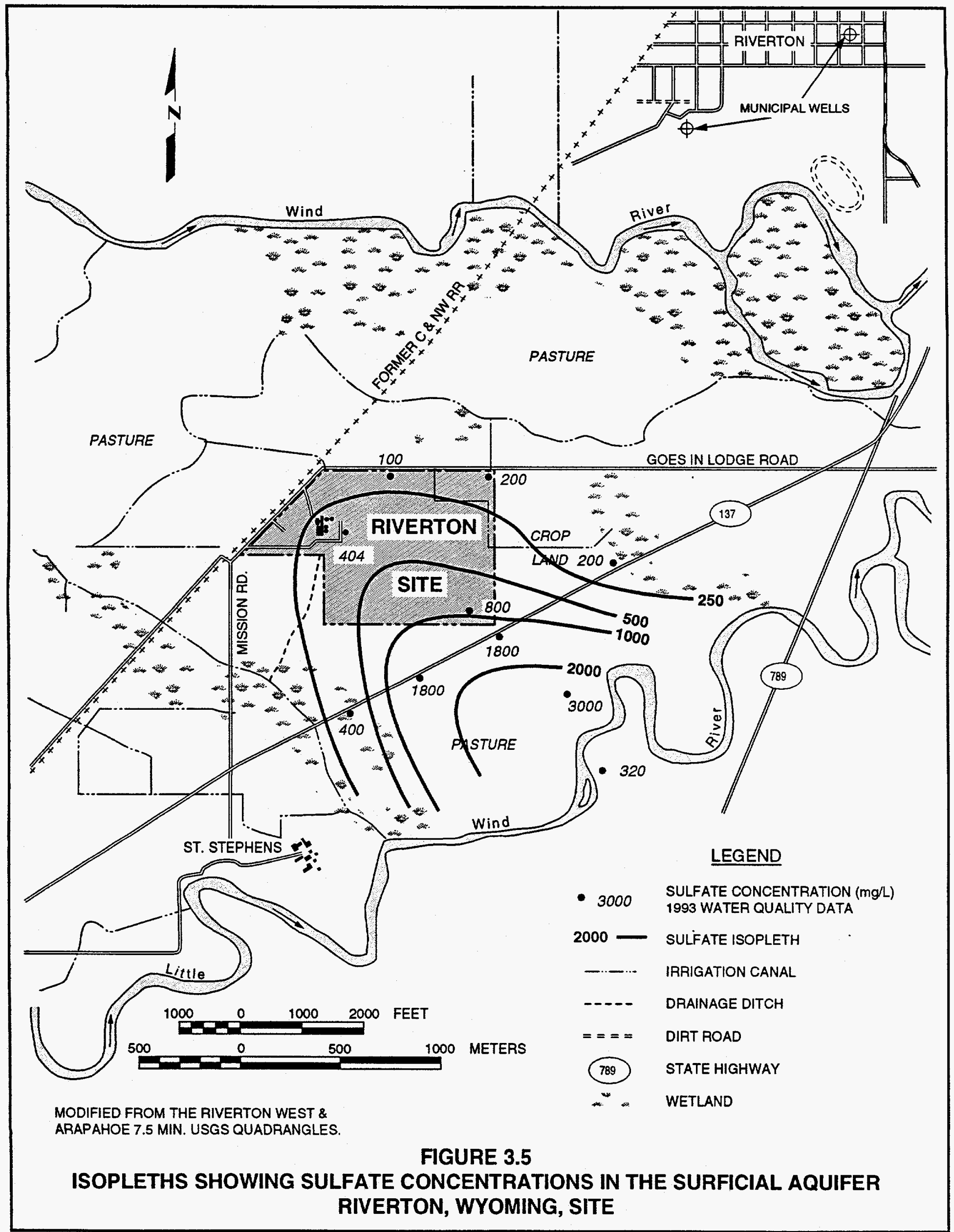


have been collected from wells in the path of the plume only since the mid-1980s. Time concentration plots using historical water quality data from the mid-1980s show scatter in the data but no apparent trend of increasing or decreasing concentrations. The center of the plume is apparently moving southeast from the site boundary.

Because the alluvium is laterally thin (5 to $10 \mathrm{ft}[1.5$ to $3.0 \mathrm{~m}]$ thick) and relatively porous, lateral dominates vertical dispersion. These conditions allow the ground water to flush contaminants from the shallow system. Figure $\mathbf{3 . 5}$ shows the probable maximum extent of the plume.

\subsubsection{Semiconfined aquifer}

The potentiometric surface of the semiconfined water-bearing unit is equal to or lower than the water table surface of the surficial aquifer in the vicinity of the abandoned mill site, suggesting ground water flows downward from the surficial aquifer into the semiconfined sandstone unit.

Water quality data have been collected from the semiconfined aquifer since 1987. These data suggest that ground water in the semiconfined aquifer is contaminated directly beneath and downgradient from the processing site. Monitor wells $108,705,717,719$, and 723 represent the plume wells in this aquifer (Table 3.3). Data from March 1993, the most recent sampling round, show that ground water levels in this region are elevated with respect to background ground water levels of manganese, strontium, sulfate, molybdenum, uranium, calcium, chloride, iron, and sodium. The sulfate concentration isopleth is shown in Figure 3.6. Contamination is moving southeast from the site, probably at a slower rate than the linear velocity of ground water.

One domestic well southeast of the site had detectable levels of arsenic 10.008 milligrams per liter [mg/L]), uranium $(0.016 \mathrm{mg} / \mathrm{L})$, and vanadium $(0.02 \mathrm{mg} / \mathrm{L})$. This well is used only for stock watering and is completed in the surficial aquifer. Contamination has not been detected in ground water from the lower confined aquifer.

\subsection{CONTAMINANTS OF POTENTIAL CONCERN}

The data presented in Sections 3.1 and 3.2 were used to compile a list of contaminants of potential concern in assessing human health risks at the site. Because contamination levels are higher in the surficial aquifer, it will be evaluated quantitatively. The less-contaminated and less-characterized semiconfined aquifer will be evaluated qualitatively (see Section 6.0).

In general, constituents were listed among contaminants of potential concern when the site was considered a likely source of the contamination and when the constituent average concentrations (measured in plume wells) exceeded average background levels at the 0.05 level of significance. Column one of Table 3.4 shows which constituents exceed surficial ground water background levels. 


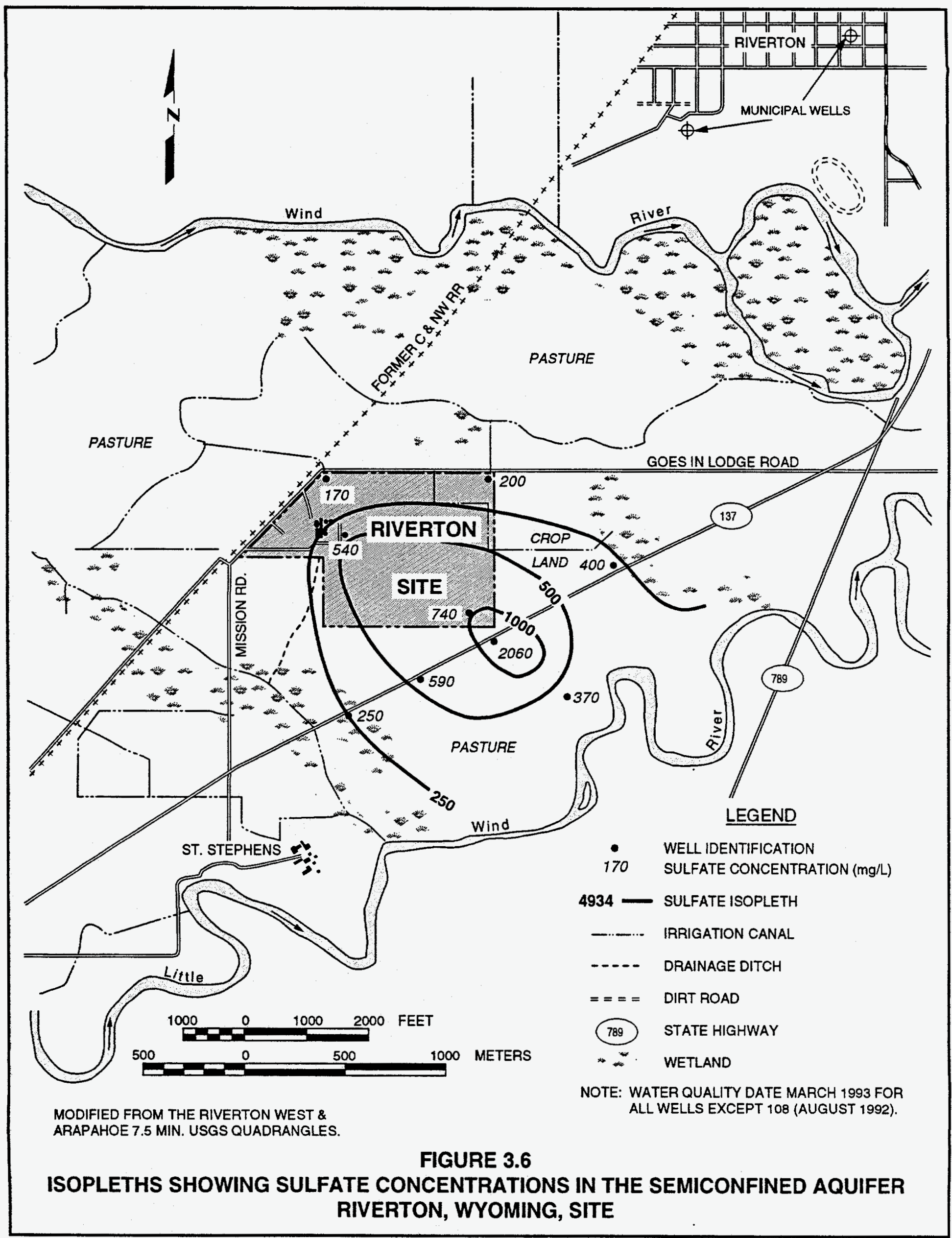


Table 3.4 Contaminants of potential concern in surficial ground water

\begin{tabular}{|c|c|c|c|}
\hline $\begin{array}{l}\text { Contaminants that } \\
\text { exceed background }\end{array}$ & $\begin{array}{l}\text { Contaminants in } \\
\text { nutritional range }\end{array}$ & $\begin{array}{l}\text { Contaminants of low } \\
\text { toxicity and/or high } \\
\text { dietary range }\end{array}$ & $\begin{array}{l}\text { Contaminants of } \\
\text { potential concern }\end{array}$ \\
\hline $\begin{array}{l}\text { Aluminum } \\
\text { Arsenic } \\
\text { Boron } \\
\text { Bromide } \\
\text { Calcium } \\
\text { Chloride } \\
\text { Fluoride } \\
\text { Iron } \\
\text { Magnesium } \\
\text { Manganese } \\
\text { Molybdenum } \\
\text { Nickel } \\
\text { Potassium } \\
\text { Selenium } \\
\text { Silica } \\
\text { Sodium } \\
\text { Strontium } \\
\text { Sulfate } \\
\text { Uranium } \\
\text { Vanadium } \\
\text { Zinc }\end{array}$ & $\begin{array}{l}\text { Calcium } \\
\text { Chloride } \\
\text { Fluoride } \\
\text { Iron } \\
\text { Potassium } \\
\text { Zinc }\end{array}$ & $\begin{array}{l}\text { Aluminum } \\
\text { Boron } \\
\text { Bromide } \\
\text { Magnesium } \\
\text { Selenium } \\
\text { Silica } \\
\text { Sodium } \\
\text { Strontium }\end{array}$ & $\begin{array}{l}\text { Arsenic } \\
\text { Manganese } \\
\text { Molybdenum } \\
\text { Nickel } \\
\text { Sulfate } \\
\text { Uranium } \\
\text { Vanadium }\end{array}$ \\
\hline \multicolumn{4}{|l|}{ Radionuclides } \\
\hline $\begin{array}{l}\text { Lead-210 } \\
\text { Polonium-210 } \\
\text { Thorium-230 }\end{array}$ & & & $\begin{array}{l}\text { Lead-210 } \\
\text { Polonium-210 } \\
\text { Thorium-230 }\end{array}$ \\
\hline
\end{tabular}

Note: Contaminants of potential concern (column 4) are determined by eliminating the contaminants listed in columns 2 and 3 from the list in column 1. 
Several of the chemical species detected above background levels are essential nutrients. These constituents were not evaluated further because they were measured within nutritional ranges (column 2). These constituents include calcium, chloride, fluoride, iron, potassium, and zinc. Several other contaminants of the surficial aquifer were screened for their low toxicity and/or low concentrations compared to high dietary intakes (column 3 ).

For the surficial aquifer, these screening criteria eliminated all contaminants but arsenic, manganese, molybdenum, nickel, sulfate, uranium, vanadium, and several radioactive progeny of the uranium decay series, including lead-210, polonium-210, and thorium-230. Column 4 of Table 3.4 lists contaminants of potential concern.

For the semiconfined aquifer, the contaminants of potential concern are manganese, molybdenum, sulfate, and uranium. No contaminants related to the site were detected in the confined aquifer.

Milling activities have influenced the surficial aquifer downgradient from the processing site. Since 1963 , when uranium ore processing ceased, natural flushing has moved the plume centroid southeast toward the Little Wind River; the most contaminated well, monitor well 707, is approximately $250 \mathrm{ft}(80 \mathrm{~m})$ from the Little Wind River.

Contaminant levels of ground water reached by monitor well 707 are elevated in comparison to background levels of arsenic, manganese, molybdenum, nickel, sulfate, uranium, and vanadium. These constituents, their predominant aqueous species, and their molar percentages are listed in Table 3.5. Aqueous species were calculated with the geochemical computer codes MINTEQA2 (Allison et al., 1991) and PHREEQE (Parkhurst et al., 1980).

The chemical species of an element is determined by the chemical composition of the ground water, including $\mathrm{pH}$, Eh, temperature, availability of ions and complexes, and concentration of the element. The mobility of a constituent depends upon its species. Toxicokinetics and toxicity also depend on the concentration and type of species present in ground water.

According to geochemical modeling MINTEOA2 (Allison et al., 1991) and PHREEQE (Parkhurst et al., 1980), monitor well 707 reaches ground water that is slightly oversaturated with barite and gypsum and moderately oversaturated with the uranium phase schoepite, hydroxides and oxyhydroxides of iron, jarosite (iron sulfate), nickel hydroxide, barium arsenate, and calcium and magnesium vanadate phases. Because kinetically favorable uranium, vanadium, nickel, arsenic, and sulfate phases precipitate and adsorb to the aquifer matrix, 
Table 3.5 Aqueous species and molar percentage of hazardous contaminants in ground water in the surficial aquifer downgradient from the Riverton, Wyoming, site

\begin{tabular}{|c|c|c|c|}
\hline $\begin{array}{l}\text { Contaminant of } \\
\text { potential concern }\end{array}$ & & $\begin{array}{l}\text { Identity of species } \\
\text { in ground water }\end{array}$ & $\begin{array}{l}\text { Approximate } \\
\text { molar } \%\end{array}$ \\
\hline \multirow[t]{2}{*}{ Arsenic $^{a}$} & Arsenate & $\mathrm{HAsO}_{4}{ }^{2-}$ & 61 \\
\hline & Arsenate & $\mathrm{H}_{2} \mathrm{AsO}_{4}^{-}$ & 39 \\
\hline \multirow[t]{3}{*}{ Manganese $^{a}$} & Manganese & $\mathrm{Mn}^{2+}$ & 62 \\
\hline & Manganese sulfate & $\mathrm{MnSO}_{4} \mathrm{AO}$ & 35 \\
\hline & Manganese carbonate & $\mathrm{MnCO}_{3}+$ & 3 \\
\hline Molybdenum ${ }^{b}$ & Molybdate & $\mathrm{MoO}_{4}{ }^{2-}$ & 100 \\
\hline \multirow[t]{4}{*}{ Nickel $^{\mathrm{a}}$} & Nickel carbonate & $\mathrm{NiCO}_{3} \mathrm{AO}$ & 59 \\
\hline & Nickel & $\mathrm{Ni}^{2+}$ & 22 \\
\hline & Nickel sulfate & $\mathrm{NiSO}_{4} \mathrm{AO}$ & 12 \\
\hline & Nickel bicarbonate & $\mathrm{NiHCO}_{3}$ & 7 \\
\hline \multirow[t]{4}{*}{ Sulfate ${ }^{a}$} & Sulfate & $\mathrm{SO}_{4}{ }^{2-}$ & 75 \\
\hline & Calcium sulfate & $\mathrm{CaSO}_{4} \mathrm{AO}$ & 12 \\
\hline & Magnesium sulfate & $\mathrm{MgSO}_{4} \mathrm{AO}$ & 9 \\
\hline & Sodium sulfate & $\mathrm{NaSO}_{4}^{-}$ & 4 \\
\hline \multirow[t]{3}{*}{ Uranium $^{a}$} & Uranium tricarbonate & $\mathrm{UO}_{2}\left(\mathrm{CO}_{3}\right)^{4-}$ & 54 \\
\hline & Uranyl dicarbonate & $\mathrm{UO}_{2}\left(\mathrm{CO}_{3}\right)_{2}^{2-}$ & 43 \\
\hline & Uranium carbonate & $\mathrm{UO}_{2}\left(\mathrm{CO}_{3}\right) \mathrm{AO}$ & 3 \\
\hline \multirow[t]{3}{*}{ Vanadium $^{\mathrm{a}}$} & Vanadate & $\mathrm{H}_{2} \mathrm{VO}_{4}^{-}$ & 73 \\
\hline & Vanadium oxide & $\mathrm{HV}_{2} \mathrm{O}_{7}^{3-}$ & 22 \\
\hline & Vanadate & $\mathrm{HVO}_{4}{ }^{2-}$ & 5 \\
\hline
\end{tabular}

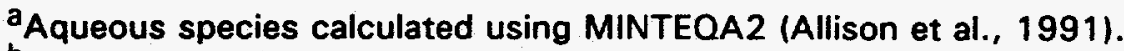

bMolybdenum speciation calculated using the geochemical code PHREEQE (Parkhurst et al., 1980). 
these constituents are removed from ground water and their concentrations are reduced.

Contaminant concentration in the plume will be influenced by the dispersive effects of dilution and by chemical reactions such as oxidation/reduction, sorption onto the aquifer matrix, coprecipitation with other mineral phases, microbial reactions, and advective transport of ground water. With distance from the source, dispersive effects will decrease the concentration of all the contaminants in the plume. The following reactions can be expected for individual contaminants:

- Arsenic is probably removed by precipitation and adsorption onto the aquifer matrix.

- Manganese is removed by coprecipitation with iron phases; when pH rises, manganese may precipitate as an oxyhydroxide.

- Nickel is oversaturated with respect to nickel hydroxide and probably coprecipitates with ferric oxyhydroxide phases.

- Sulfate is probably removed by the precipitation of gypsum and possibly other sulfate mineral phases.

- Uranium is probably attenuated because of the precipitation of schoepite and adsorption onto the aquifer matrix.

- Vanadium is oversaturated with respect to calcium and magnesium vanadate mineral phases and may be removed if the kinetics are favorable (little is known about the precipitation kinetics of these phases). Vanadium also may be removed through adsorption onto the aquifer matrix.

\subsection{SURFACE WATERING MONITORING}

Surface waters in the site vicinity could be affected by contaminated ground water discharge. Contaminants could also have migrated before remediation to surface water bodies through surface runoff. The surface waters in the site vicinity that could be impacted by site contaminants include the Little Wind River, wetland areas south and east of the site, and the drainage ditch and stream southwest of the site. These areas were sampled in June 1993. Sampling results and their potential impacts are discussed in Section 7.0. 


\subsection{EXPOSURE ASSESSMENT}

\subsection{POTENTIALLY EXPOSED POPULATION}

Ground water is withdrawn at numerous points within a $2-\mathrm{mi}(3-\mathrm{km})$ radius of the site. Most of these are residential wells used for drinking and other household purposes. Although these wells generally pump water from the deeper confined sandstone, which is not affected by site-related contamination, the shallower ground water is sometimes used to water livestock or for other nondrinking purposes. One of these wells showed signs of low-level contamination.

This risk assessment evaluates shallow ground water as a future source of drinking water for residences near the Riverton site. Contaminant concentrations in monitor well 707 (in the sampling cluster southeast of the site) are specifically considered because the contaminant levels were generally higher there.

The evaluation of potentially contaminated surface water and sediment relates to both current and future use. Maximum detected concentrations in surface water and sediments are evaluated for current and future residents.

This assessment evaluates domestic ground water uses and recreational surface water uses consistent with those of this region's rural population. The potentially exposed population is divided into the following age groups: infants (birth to 1 year), children (1 to 10 years), and adults (11 to 65 years). These age groups were selected for the following reasons:

- Availability of survey data for population variables such as age, weight, and daily water intake.

- Similarity of toxicological variables, including responsiveness of sensitive subgroups (infants and children) to the contaminants of potential concern, toxicant intake-to-body-weight ratios, and toxicokinetics.

\subsection{EXPOSURE PATHWAYS}

Ground water in the region is used primarily for household purposes such as drinking, cooking, and bathing. Other uses typical of the region that could indirectly lead to human exposure are irrigation and livestock watering. Bodies of surface water in the area are other potential sources of human exposure. Recreational use of the river and other water bodies (i.e., drainage ditches, stream, and wetland areas) could lead to direct human exposure to surface water and sediment and to indirect exposure if fish caught from the river are eaten. Figure 4.1 provides a conceptual model for potential exposure pathways. To determine which pathways contribute significantly to exposure, the following pathways are screened using adult default parameters. 


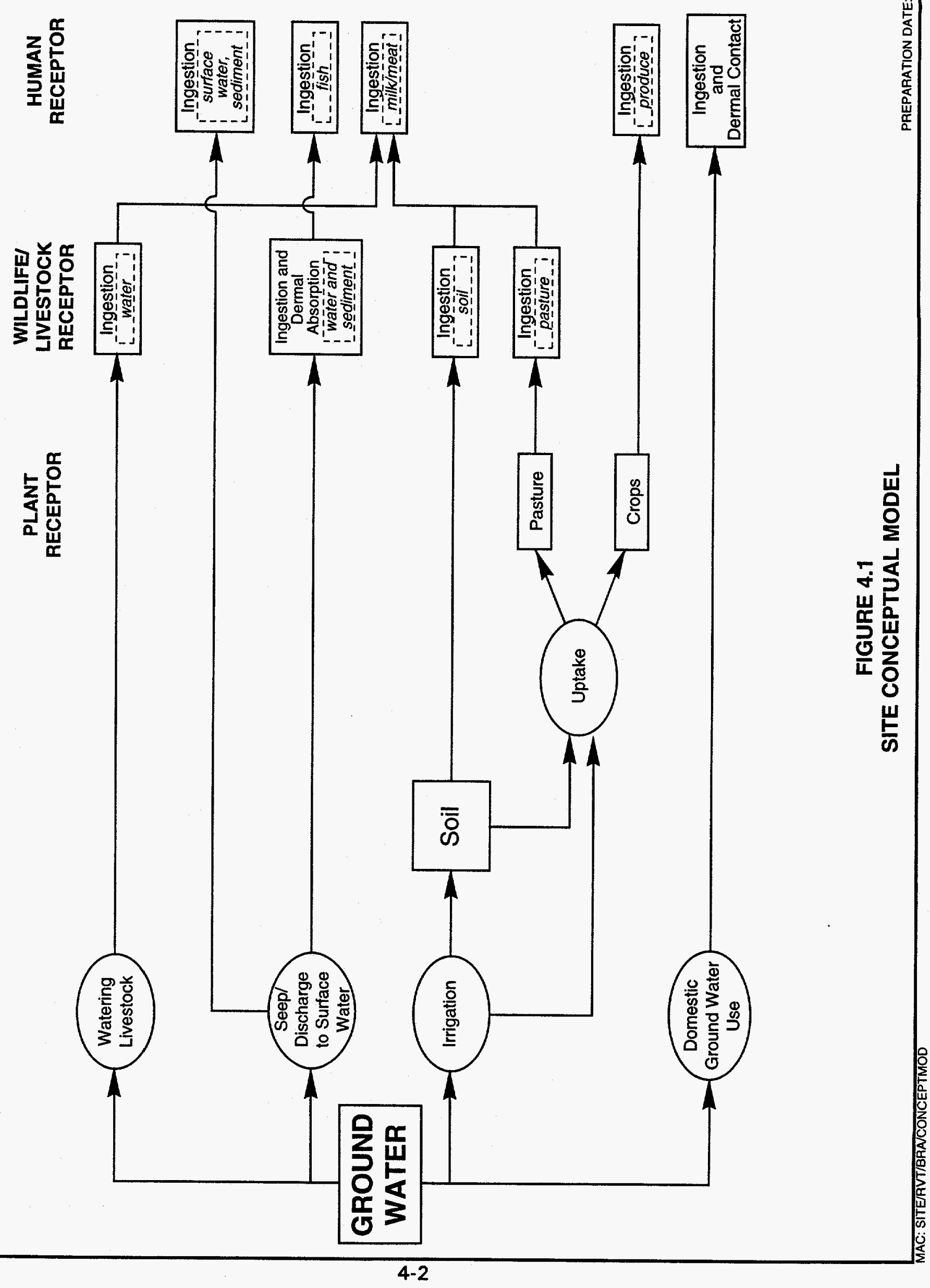




\subsubsection{Drinking water ingestion}

Drinking water ingestion is generally the most significant exposure route for ground water contaminated with metals and other nonvolatile compounds. In this evaluation, the definition of drinking water includes water used for drinking and for food preparation (e.g., reconstituted juices, soup, rice, beans). For a comparison of the significance of relative pathways, Table 4.1 shows a screening level assessment of drinking water intake for adults. Section 4.4 contains a further probability evaluation.

\subsubsection{Dermal absorption}

In the dermal absorption process, chemicals in contact with the skin are absorbed by blood vessels near the skin surface. Although some compounds are easily absorbed, the chemical properties of metals are not generally conducive to skin absorption.

To evaluate this exposure route, a screening calculation was used to compare the significance of dermal absorption to the drinking water pathway. Because chemical-specific absorption factors are not available for these contaminants, they are assumed to absorb across the skin at the rate of water. This assumption probably overestimates the potential contribution of dermal absorption.

Although the dermal dose is an absorbed dose and the ingested dose is a total dose of which only some percentage will be absorbed, the very low contribution of dermal absorption ( 0.2 percent) is assumed to be insignificant compared to ingestion. Based on these results, dermal absorption is eliminated from more detailed evaluation and is discussed qualitatively in Section 6.0.

\subsubsection{Ingestion of ground water-irrigated produce}

This exposure route was evaluated for its relative significance in comparison to the drinking water ingestion route. Table 4.2 shows results of the screening calculation. The assumptions for this evaluation are likely to overestimate the potential for exposure from this route, since it is assumed that this garden would be the source of all garden produce in the diet. The results of this screening show that for contaminants of potential concern, ingestion of vegetables and fruit irrigated with contaminated ground water would lead to potential exposures of less than 3 percent of the levels associated with drinking contaminated water. Therefore, this pathway is eliminated from detailed evaluation and is discussed qualitatively in Section 6.0.

\subsubsection{Ingestion of meat from ground water-fed livestock}

The meat-ingestion pathway was evaluated in relation to the drinking water-ingestion route. The results of the screening (Table 4.3) show that for the contaminants of potential concern in ground water, the beef-ingestion 


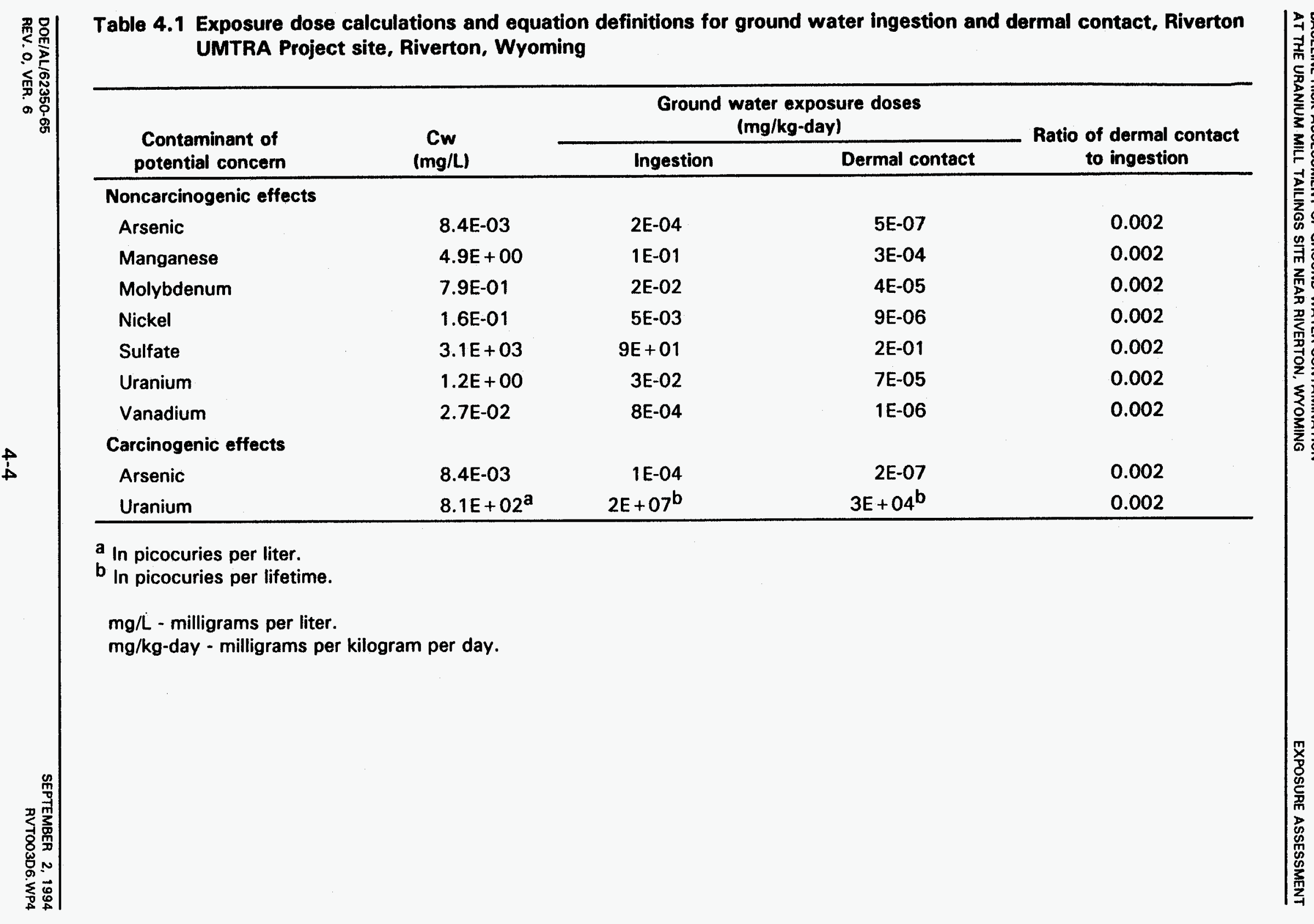




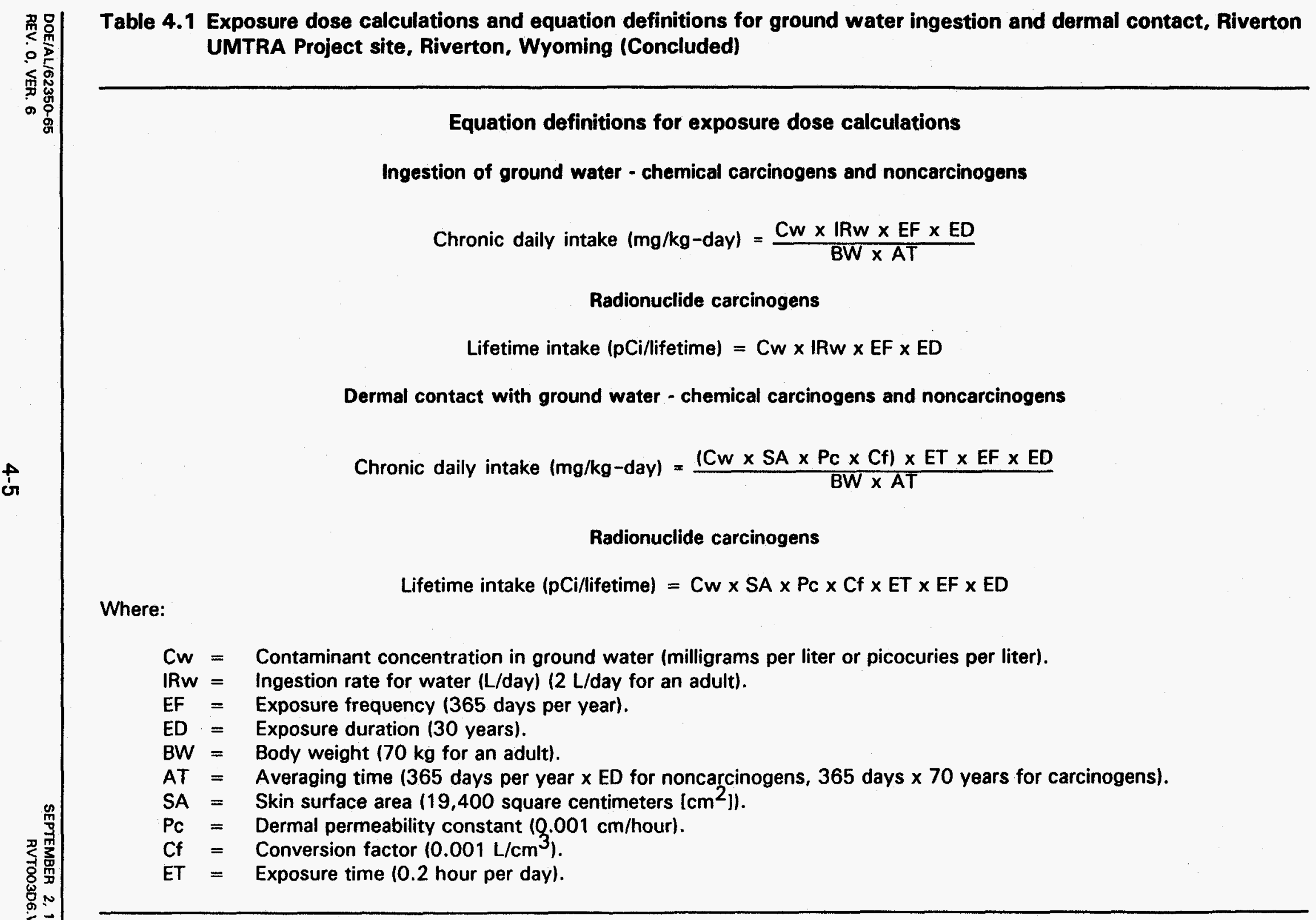




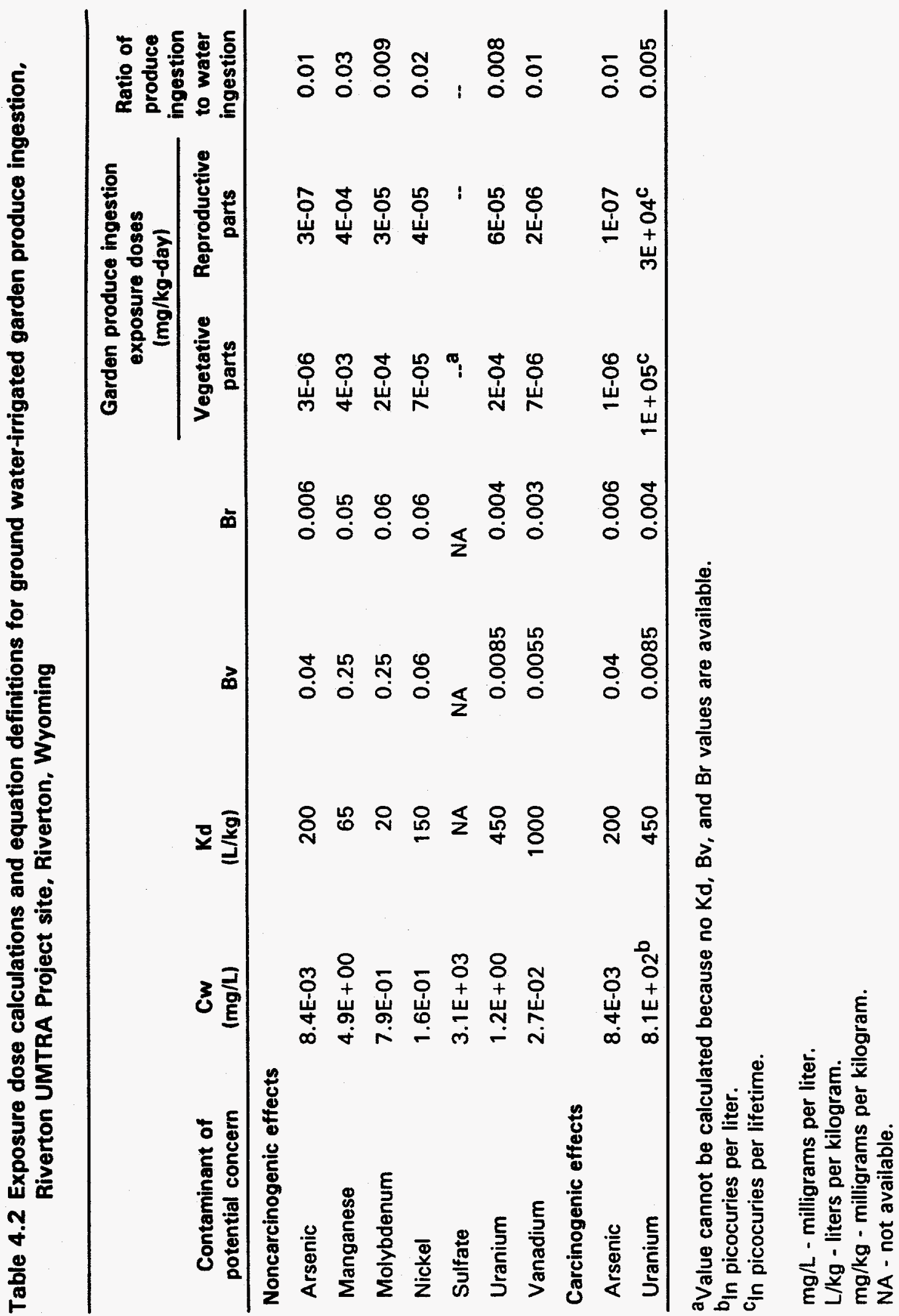




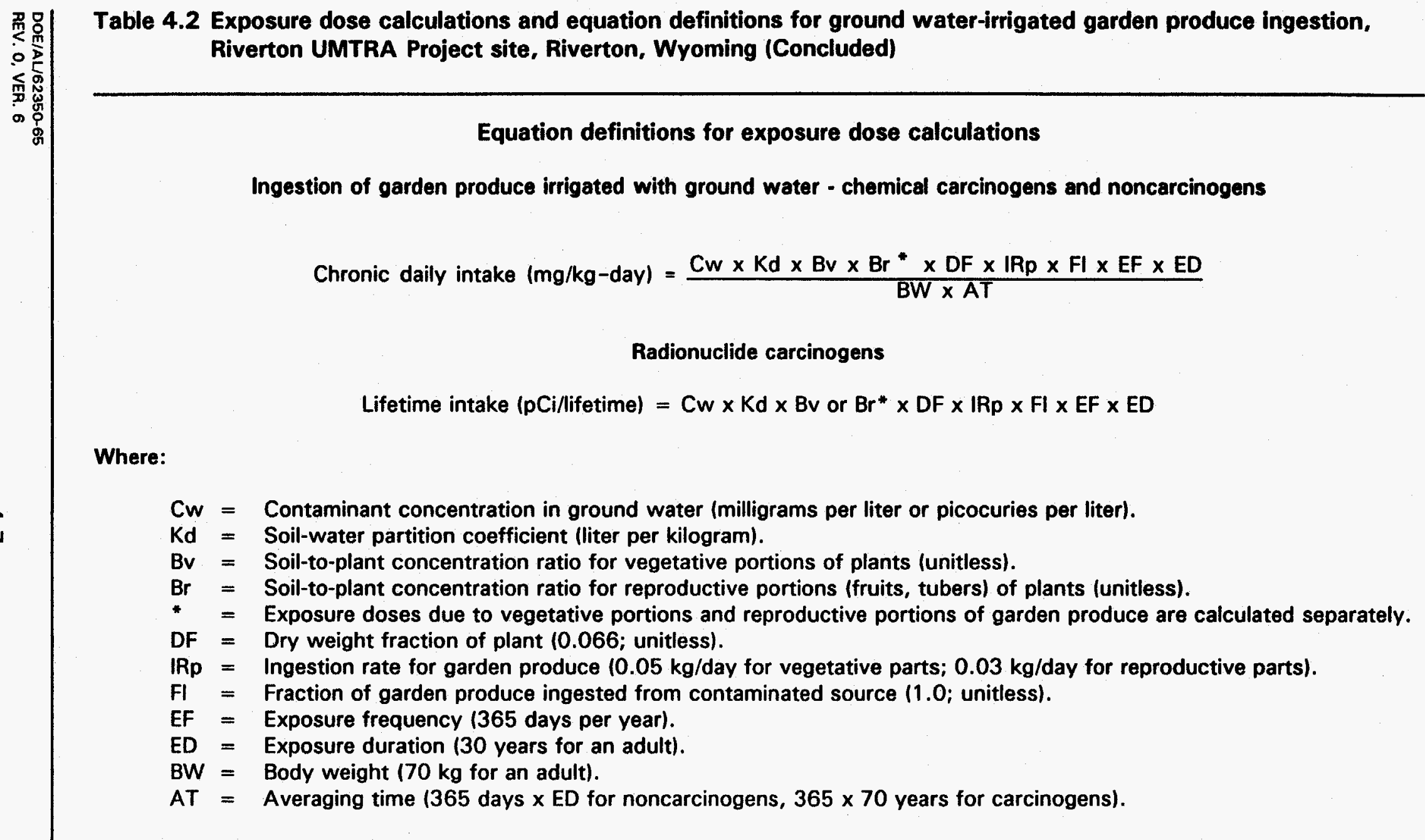




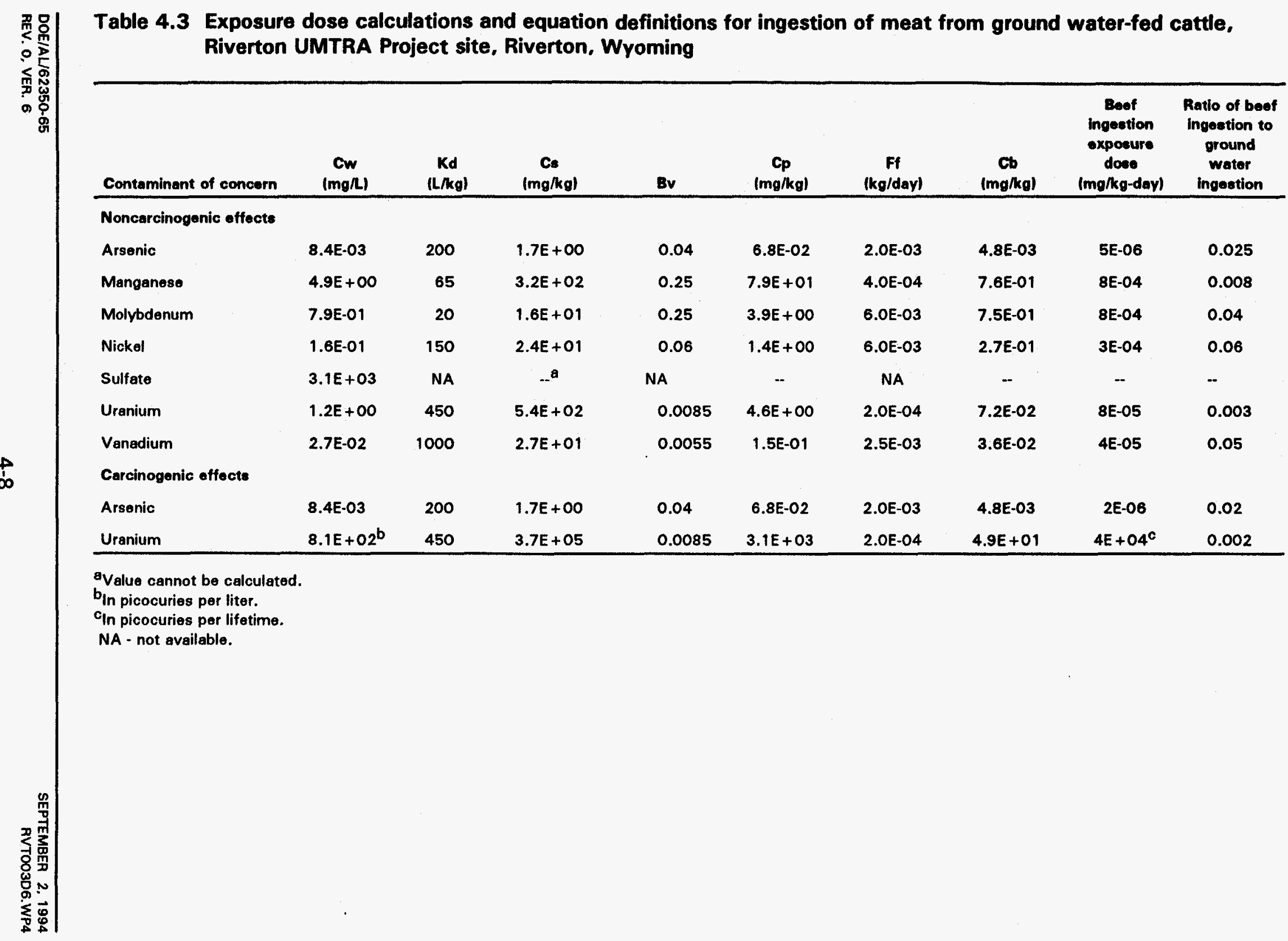


Table 4.3 Exposure dose calculations and equation definitions for ingestion of meat from ground water-fed cattle, Riverton UMTRA Project site, Riverton, Wyoming (Concluded)

\author{
Equation definitions for exposure dose calculations \\ Ingestion of meat from ground water-fed cattle \\ Chemical carcinogens and noncarcinogens \\ Chronic daily intake $(\mathrm{mg} / \mathrm{kg}-$ day $)=\frac{\mathrm{Cb} \times \mathrm{IRb} \times \mathrm{FI} \times \mathrm{EF} \times \mathrm{ED}}{B W \times \mathrm{AT}}$ \\ Radionuclide carcinogens \\ Lifetime intake $(\mathrm{pCi} /$ lifetime $)=\mathrm{Cb} \times \mathrm{IRb} \times \mathrm{FI} \times \mathrm{EF} \times \mathrm{ED}$ \\ $\mathrm{Cb}=\mathrm{Ff}([\mathrm{Cw} \times \mathrm{Ow}]+[\mathrm{Cs} \times \mathrm{Qs}]+[\mathrm{Cp} \times \mathrm{Qp}])$ \\ $\mathrm{Cs}=\mathrm{Cw} \times \mathrm{Kd}$ \\ $\mathrm{Cp}=\mathrm{Cs} \times \mathrm{Bv}$
}

Where:

$\mathrm{Cb}=$ Contaminant concentration in beef (milligrams per kilogram or picocuries per kilogram).

$\mathrm{IRb}=$ Ingestion rate for beef $10.075 \mathrm{~kg} /$ day for an adult).

$\mathrm{FI}=$ Fraction ingested from contaminated source (1.0 unitless).

$\mathrm{EF}=$ Exposure frequency ( 365 days per year).

$E D=$ Exposure duration ( 30 years for an adult).

BW = Body weight $(70 \mathrm{~kg}$ for an adult $)$.

$A T=$ Averaging time ( 365 days per year $\times$ ED for noncarcinogens; 365 days per year $\times 70$ for carcinogens).

$\mathrm{Ff}=$ Chemical-specific ingestion-to-beef transfer coefficient (unitless).

$\mathrm{CW}_{w}=$ Contaminant concentration in ground water (milligrams per liter or picocuries per liter).

Ow = Quantity of ground water consumed daily by cattle (56 L/day).

$\mathrm{Cs}=$ Contaminant concentration in soil (milligrams per kilogram or picocuries per kilogram).

Qs = Quantity of soil ingested daily by cattle $(0.38 \mathrm{~kg} / \mathrm{day})$.

$\mathrm{Cp}=$ Contaminant concentration in plant material consumed by cattle Imilligrams per kilogram or picocuries per kilogram).

$\mathrm{Qp}$ = Quantity of plant material consumed daily by cattle $(19 \mathrm{~kg} /$ day).

$\mathrm{Kd}=$ Chemical-specific soil-to-water distribution coefficient (unitless).

$\mathrm{Bv}=$ Chemical-specific soil-to-plant concentration factor (unitless). 
pathway would produce a potential exposure of less than 6 percent of that associated with the ground water-ingestion pathway. Therefore, this pathway is eliminated from further evaluation. The potential increment of meat-ingested sulfate to drinking water exposure is discussed in detail in Section 6.3. Further evaluation of the direct toxicity to livestock is presented in Section 7.0.

\subsubsection{Ingestion of milk from ground water-fed livestock}

The milk-ingestion pathway was similarly evaluated for its relative significance to the ground water-ingestion route. The results of the screening calculation (Table 4.4) indicate that for the contaminants of potential concern in ground water, the milk-ingestion pathway would lead to a potential exposure of less than 4 percent of that associated with the drinking water-ingestion pathway. Therefore, this pathway is eliminated from detailed evaluation and is evaluated qualitatively in Section 6.0.

4.2.6 Incidental ingestion of surface water while swimming and ingestion of fish from the Little Wind River

These pathways were evaluated using the maximum concentration for each contaminant of potential concern detected in the Little Wind River. Surface water samples from the stream, ditches, and wetland areas near the tailings site are not considered in this evaluation because swimming and fishing are considered unlikely in these areas. Table 4.5 identifies the maximum concentration detected for each constituent in the Little Wind River and the sampling location where these concentrations were found. Table 4.5 also presents potential exposure doses for incidental ingestion of surface water and fish. When ingestion exposure doses calculated for surface water and fish ingestion scenarios are compared with nutritional and dietary intake ranges and acceptable daily intakes, the comparison indicates that the ingestion doses fall more than two orders of magnitude below these recommended intakes. Thus, these exposure routes were eliminated from further evaluation.

\subsubsection{Incidental ingestion of sediment during recreational activities}

This exposure route was evaluated using the maximum concentration detected for each contaminant of potential concern in sediments sampled from either the Little Wind River or the other water bodies in the site vicinity. Table 4.6 identifies the maximum sediment concentration detected and the location where each concentration was detected. Table 4.6 also presents potential exposure doses for these concentrations. The incidental sediment ingestion route was eliminated from further evaluation because the calculated ingestion doses fall more than three orders of magnitude below nutritional and dietary ranges or acceptable daily intakes. 


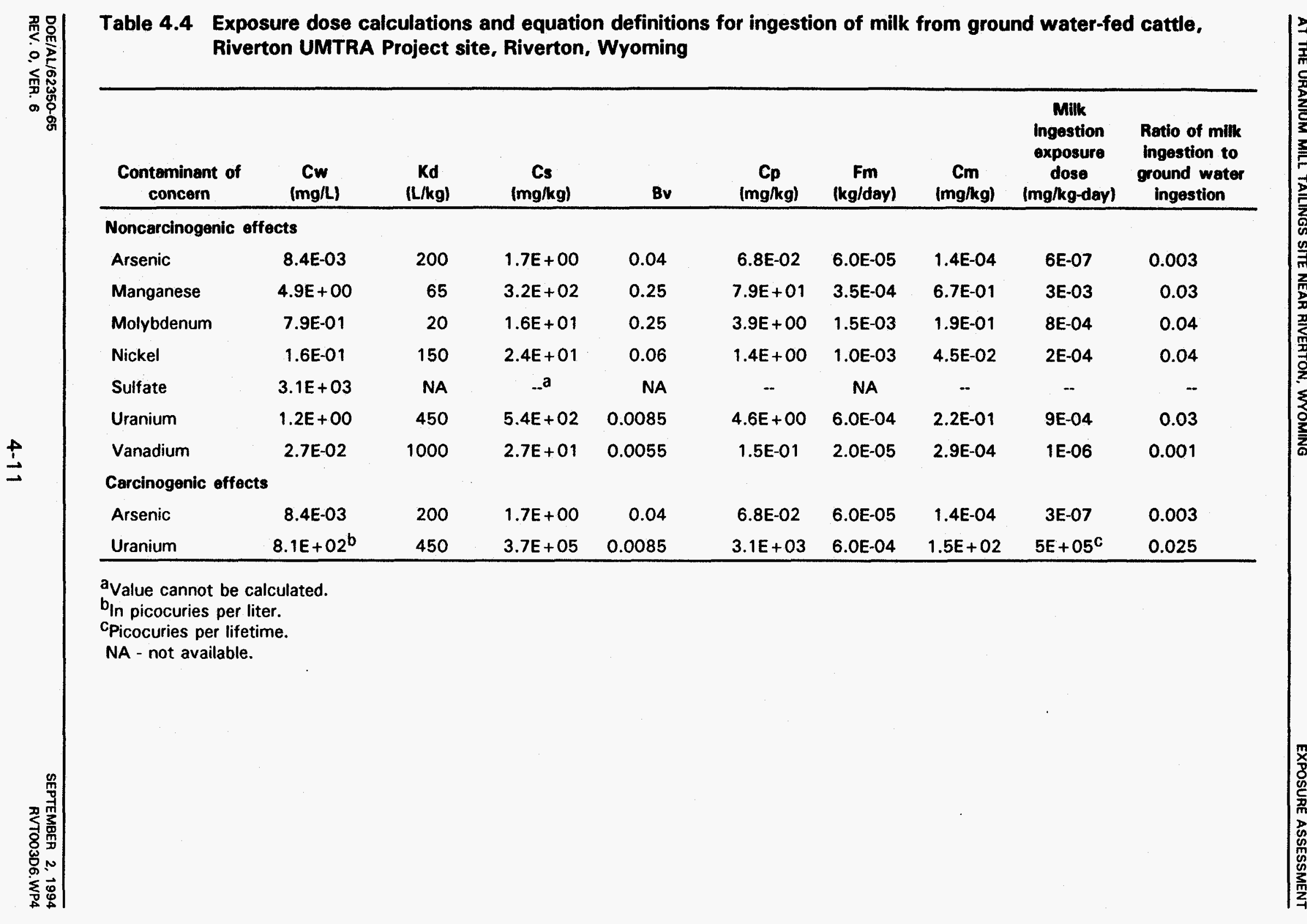




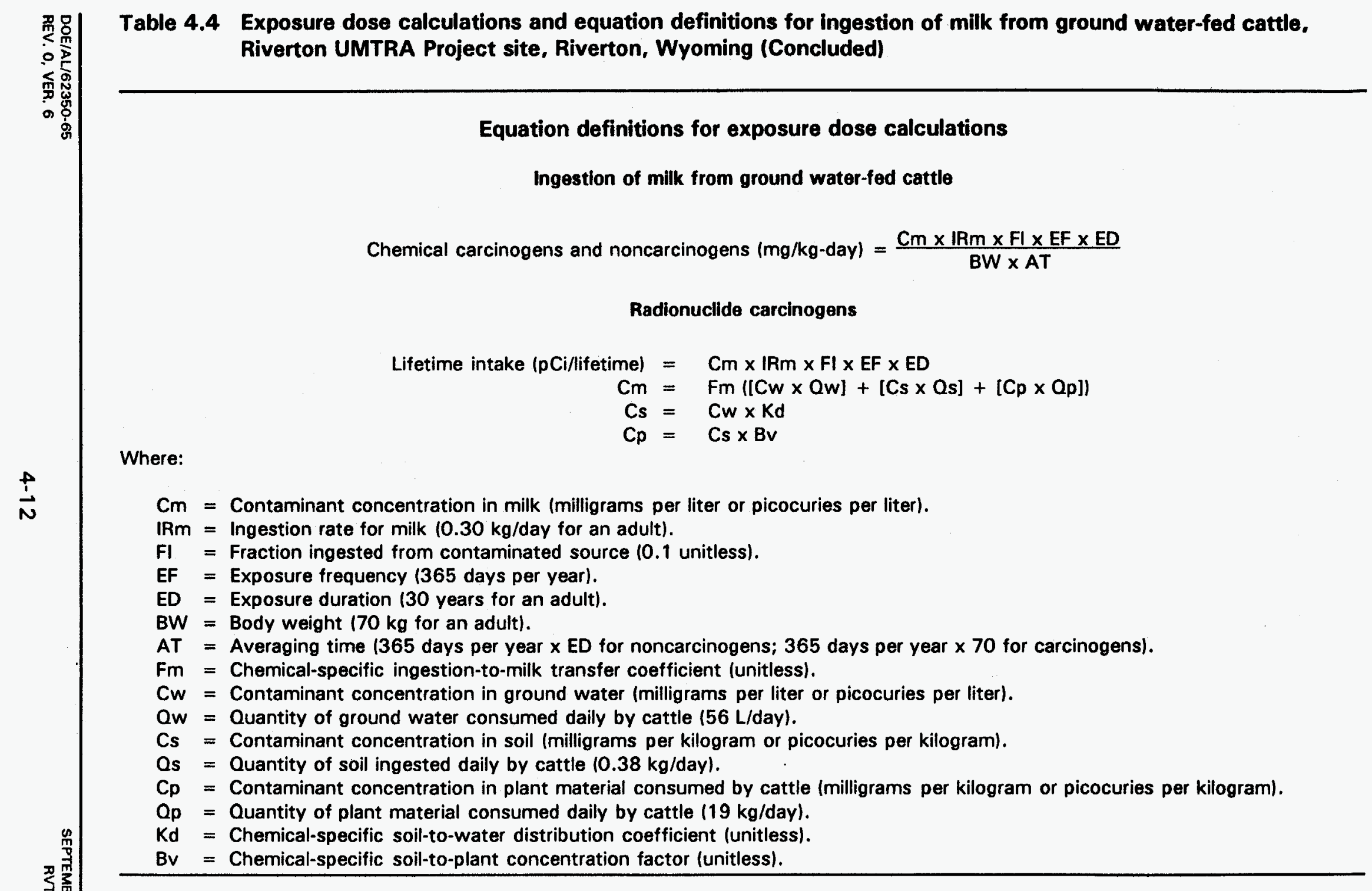


Table 4.5 Exposure dose calculations and equation definitions for incidental surface water ingestion and ingestion of fish from the Little Wind River, Riverton UMTRA Project site, Riverton, Wyoming

\begin{tabular}{|c|c|c|c|c|c|c|}
\hline Constituent & $\underset{(m g / L)}{C s w}$ & Location ID & $\begin{array}{c}\text { BCF } \\
(\mathrm{L} / \mathrm{kg})\end{array}$ & $\begin{array}{c}\text { Cf } \\
\text { (mg/kg) }\end{array}$ & $\begin{array}{c}\text { Surface } \\
\text { water } \\
\text { ingestion } \\
\text { exposure } \\
\text { dose } \\
\text { (mg/kg-day) }\end{array}$ & $\begin{array}{c}\text { Fish } \\
\text { ingestion } \\
\text { exposure } \\
\text { dose } \\
\text { (mg/kg-day) }\end{array}$ \\
\hline \multicolumn{7}{|c|}{ Noncercinogenic effects } \\
\hline Calcium & $4.2 E+01$ & 796 & NA & NA & $2 \mathrm{E}-03$ & NA \\
\hline Iron & 3.1E+OO & 796 & 100 & $3.1 E+02$ & $1 E-04$ & $6 E-02$ \\
\hline Magnesium & $1.4 \mathrm{E}+01$ & 796 & NA & NA & $5 E-04$ & NA \\
\hline Manganese & $1.4 \mathrm{E}-01$ & 796 & NA & NA & $5 E-06$ & NA \\
\hline Uranium & $2.5 \mathrm{E}-02$ & 742 & 2.0 & 5.OE-O2 & $9 \mathrm{E}-07$ & $1 E-05$ \\
\hline \multicolumn{7}{|c|}{ Carcinogenic effects } \\
\hline Uranium & $1.7 \mathrm{E}+01^{\mathrm{a}}$ & 742 & 2.0 & $3.4 E+01^{b}$ & $5 E+O 2^{C}$ & $5 E+03^{C}$ \\
\hline
\end{tabular}

an picocuries per liter.

$b_{\text {in picocuries per kilogram. }}$

$\mathrm{C}_{\text {In picocuries per lifetime. }}$

BCF-bioconcentration factor (EPA, 1992a; NUREG, 1986).

NA-BCF not available for this contaminant.

Equation definitions for exposure dose calculations

Incidental surface water ingestion during swimming

Chemical carcinogens and noncarcinogens

Chronic daily intake $(\mathrm{mg} / \mathrm{kg}$-day $)=\frac{\operatorname{Csw} \times \operatorname{CR} \times \mathrm{ET} \times \mathrm{EF} \times \mathrm{ED}}{\mathrm{BW} \times \mathrm{AT}}$

Radionuclide carcinogens

Where:

Lifetime intake $(p C i /$ lifetime $)=\mathrm{Csw} \times \mathrm{CR} \times \mathrm{ET} \times \mathrm{EF} \times \mathrm{ED}$

Csw = Maximum detected constituent concentration in surface water (milligrams per liter or picocuries per liter).

$\mathrm{CR}=$ Contact rate (amount ingested) during swimming $(0.05 \mathrm{~L} /$ hour).

ET = Exposure time per swimming event (2.6 hours per event).

$E F=$ Exposure frequency ( 7 days per year).

$E D=$ Exposure duration ( 30 years for an adult).

BW = Body weight ( $70 \mathrm{~kg}$ for an adult).

$\mathrm{AT}=$ Averaging time $(365$ days per year $\times \mathrm{ED}$ for noncarcinogens; 365 days per year $\times 70$ for carcinogens). 
Table 4.5 Exposure dose calculations and equation definitions for incidental surface water ingestion and ingestion of fish from the Little Wind River, Riverton UMTRA Project site, Riverton, Wyoming (Concluded)

Ingestion of fish caught in the Little Wind River

Chemical carcinogens and noncarcinogens

Chronic daily intake $(\mathrm{mg} / \mathrm{kg}-$ day $)=\frac{\text { Cf } \times \mathbb{R} \times \mathrm{FI} \times \mathrm{EF} \times \mathrm{ED}}{\mathrm{BW} \times \mathrm{AT}}$

\section{Radionuclide carcinogens}

Lifetime intake ( $\mathrm{pCi} /$ lifetime $)=\mathrm{Cf} \times \mathrm{IR} \times \mathrm{FI} \times \mathrm{EF} \times \mathrm{ED}$

Where:

Cf $=$ Constituent concentration in fish tissue (milligrams per kilogram or picocuries per kilogram). Calculated by multiplying the contaminant concentration in surface water (Csw) by the chemical-specific bioconcentration factor (BCF).

IR = Fish ingestion rate (kilograms per day). Based on average consumption of two 8-ounce servings per week $10.054 \mathrm{~kg} /$ day for an adult).

$\mathrm{FI}=$ Fraction ingested from contaminated source $(0.25$ unitless).

$E F=$ Exposure frequency ( 365 days per year).

$E D=$ Exposure duration ( 30 years for an adult).

BW $=$ Body weight $(70 \mathrm{~kg}$ for an adult).

$A T=$ Averaging time ( 365 days per year $\times$ ED for noncarcinogens, 365 days per year $\times 70$ for carcinogens). 
Table 4.6 Exposure dose calculations and equation definitions for incidental sediment ingestion during recreational use of the Little Wind River and other surrounding water bodies, Riverton UMTRA Project site, Riverton, Wyoming

\begin{tabular}{lccc}
\hline \multicolumn{1}{c}{ Constituent } & $\begin{array}{c}\text { Cs } \\
(\mathbf{m g} / \mathbf{k g})\end{array}$ & Location ID & $\begin{array}{c}\text { Sediment ingestion } \\
\text { exposure dose } \\
\text { (mg/kg-day) }\end{array}$ \\
\hline $\begin{array}{l}\text { Noncarcinogenic effects } \\
\text { Iron }\end{array}$ & $2.12 \mathrm{E}+04$ & 742 & $4 \mathrm{E}-05$ \\
Lead & $6.77 \mathrm{E}+01$ & 746 & $1 \mathrm{E}-07$ \\
Manganese & $6.18 \mathrm{E}+02$ & 742 & $1 \mathrm{E}-06$ \\
Molybdenum & $9.00 \mathrm{E}+00$ & 746 & $2 \mathrm{E}-08$ \\
$\quad$ Uranium & $1.13 \mathrm{E}+01$ & 746 & $2 \mathrm{E}-08$ \\
Carcinogenic effects & & & \\
$\quad$ Uranium & $7.68 \mathrm{E}+03^{\mathrm{a}}$ & 746 & $1 \mathrm{E}+01^{\mathrm{b}}$ \\
\hline
\end{tabular}

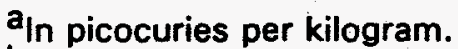

$b_{\text {In picocuries per lifetime. }}$

\section{Equation definitions for exposure dose calculations}

Chemical carcinogens and noncarcinogens

Chronic daily intake $(\mathrm{mg} / \mathrm{kg}-$ day $)=\frac{C s \times \mathbb{R} \times E F \times E D \times C F \times A B S}{B W \times A T}$

Radionuclide carcinogens

Lifetime intake $(\mathrm{pCi} /$ lifetime $)=\mathrm{Cs} \times \mathrm{IR} \times \mathrm{EF} \times \mathrm{ED} \times \mathrm{CF} \times \mathrm{ABS}$

Where:

Cs = Maximum detected constituent concentration in sediments (milligrams per kilogram or picocuries per kilogram).

IR = Ingestion rate of sediments $(6.25 \mathrm{mg} /$ day $)$.

$E F=$ Exposure frequency $(7$ days per year).

$E D=$ Exposure duration ( 30 years for an adult).

$\mathrm{CF}=$ Conversion factor $(1.0 \mathrm{E}-06 \mathrm{~kg} / \mathrm{mg})$.

$A B S=$ Chemical-specific gastrointestinal absorption factor (default value of 1.0 for all metals).

$B W=$ Body weight $(70 \mathrm{~kg}$ for an adult $)$.

$A T=$ Averaging time (365 days per year $x$ ED). 


\subsection{EXPOSURE CONCENTRATIONS FOR DRINKING WATER}

The exposure concentration of a contaminant in ground water is defined as the concentration an individual is assumed to take in over a specific period. In this evaluation, contaminant concentrations are assumed to stay in a steady state, even though site remediation should actually cause a decrease in exposure concentrations over time. Nonetheless, these estimates are reasonable for chronic exposure soon after remediation. (Chronic exposure for noncarcinogens is considered to be any period greater than 7 years.)

Exposure concentrations are evaluated as a probability of occurrence based on ground water data collected from monitor well 707 in the surficial aquifer between the Little Wind River and the former processing site. This well is used in this assessment because it has generally shown the highest contamination levels over the past 7 years of monitoring.

The probability distribution selected for a contaminant had approximately the same mean, median, standard deviation, and shape as were observed in the historical water quality data. The upper tail of the distributions were truncated at the 99th percentile. For every contaminant, the truncated upper limit concentration was higher than the maximum observed concentration in the historical water quality data. The software package @RISK was used to generate probability curves for the contaminants of potential concern; results are shown in Figures 4.2 through 4.8. The expected values shown on the probability curves are the mean of the 10,000 iterations used to generate them and can be considered an average.

\subsection{ESTIMATED DRINKING WATER INTAKE}

Individuals within the population of future residents are expected to vary in water consumption habits, stable body weight, and length of time they reside in the affected area. Consequently, health risks associated with ground water consumption will also vary among members of this population. To adequately describe the range of potential risks to the future population, naturally occurring variabilities in daily water intake and body weight were incorporated into this assessment through probability distributions selected from published United States public health and census documents. All distributions were truncated at the upper and lower 0.01 percentile. Within the hypothetical population, the probability of occurrence for values disallowed through this truncation is less than 1 in 10,000 .

The potential toxicity of noncarcinogenic contaminants in drinking water depends primarily on long-term (i.e., at least 7 years) average daily consumption of the contaminant per kilogram of body weight (measured in milligrams per kilogram per day [mg/kg-dayl). For noncarcinogens, exposure frequency multiplied by exposure duration in the numerator is assumed to cancel out with 


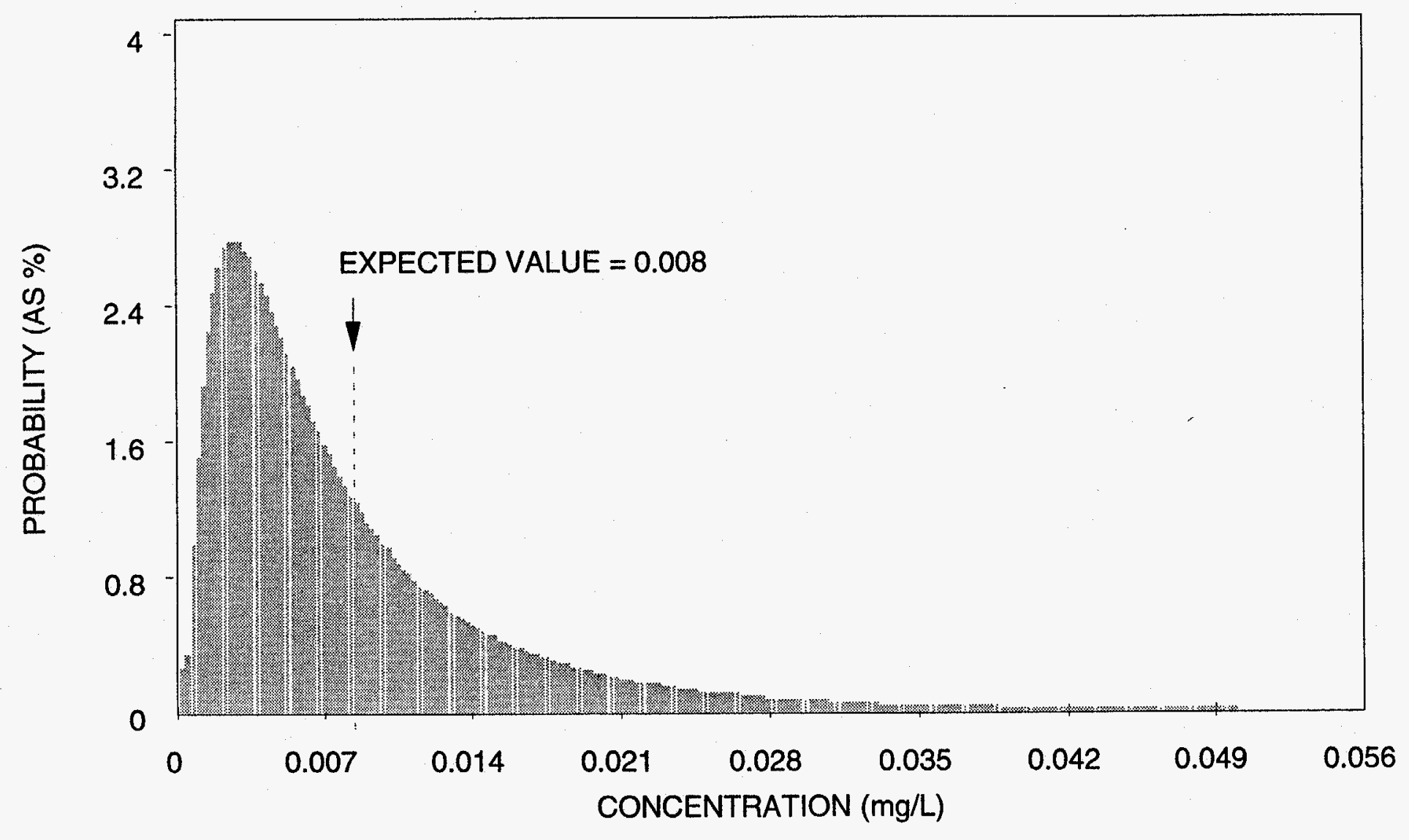

FIGURE 4.2

SIMULATED DISTRIBUTION OF ARSENIC CONCENTRATIONS

RIVERTON, WYOMING, SITE 


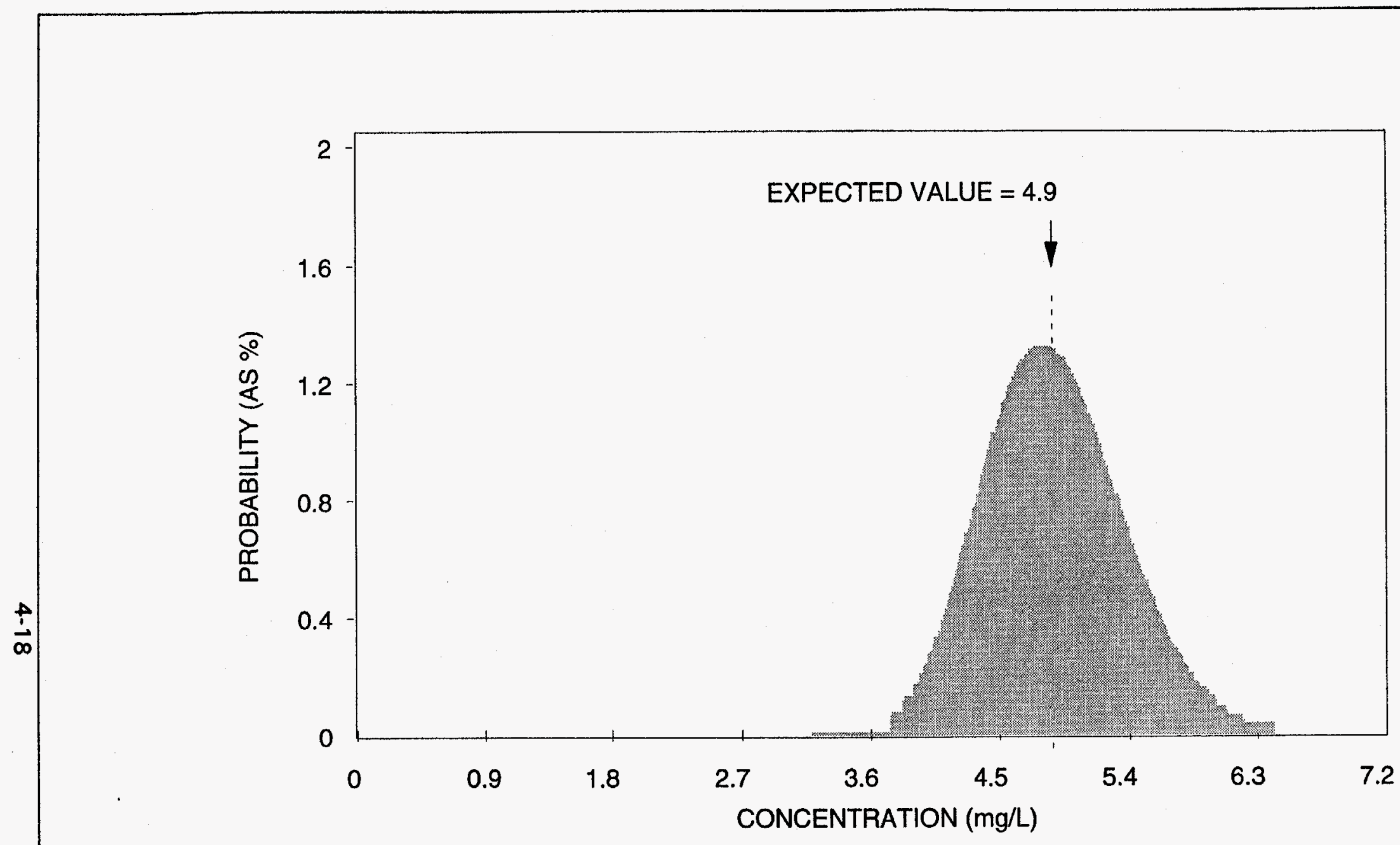

FIGURE 4.3

SIMULATED DISTRIBUTION OF MANGANESE CONCENTRATIONS

RIVERTON, WYOMING, SITE 


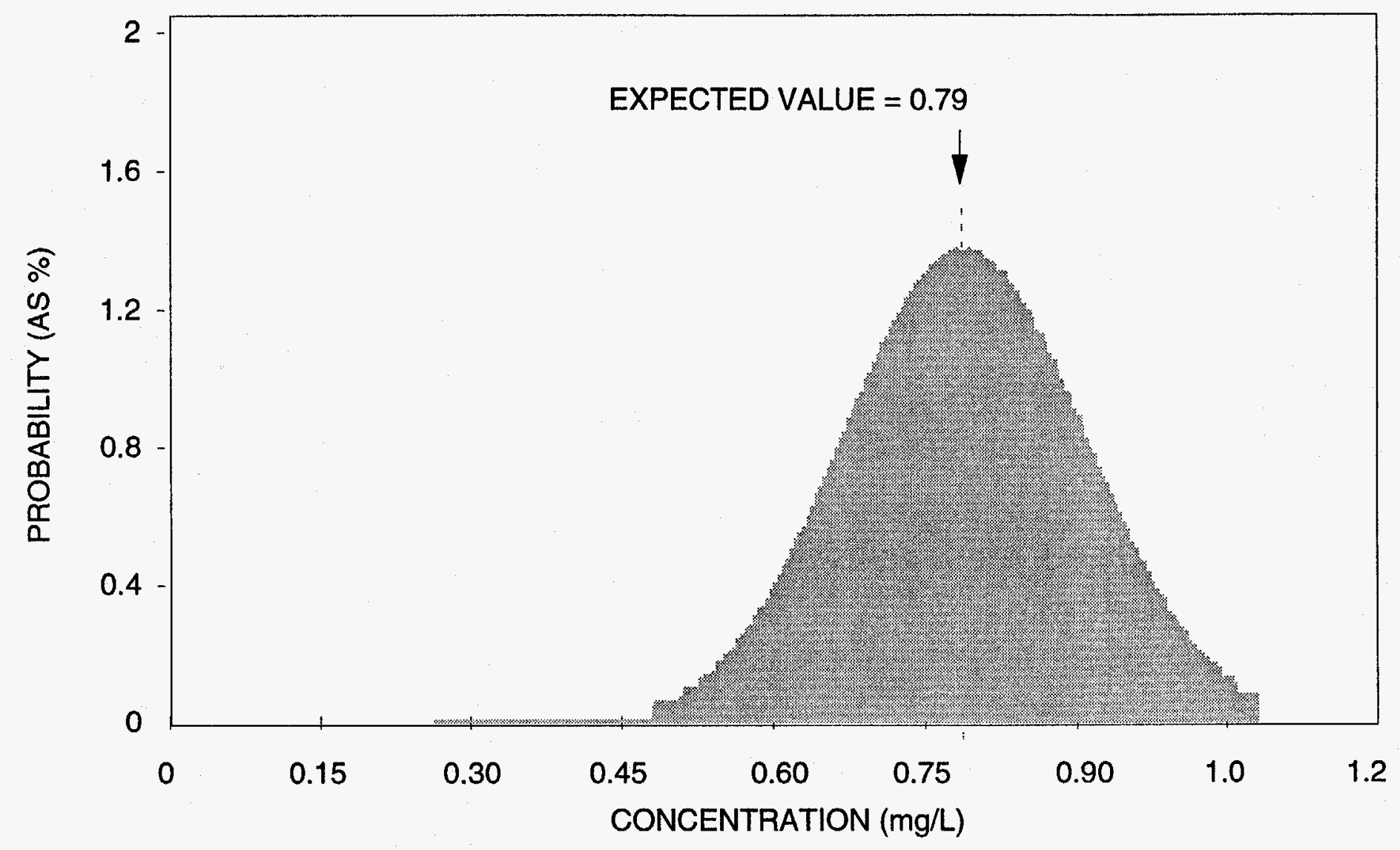

FIGURE 4.4

SIMULATED DISTRIBUTION OF MOLYBDENUM CONCENTRATIONS

RIVERTON, WYOMING, SITE 

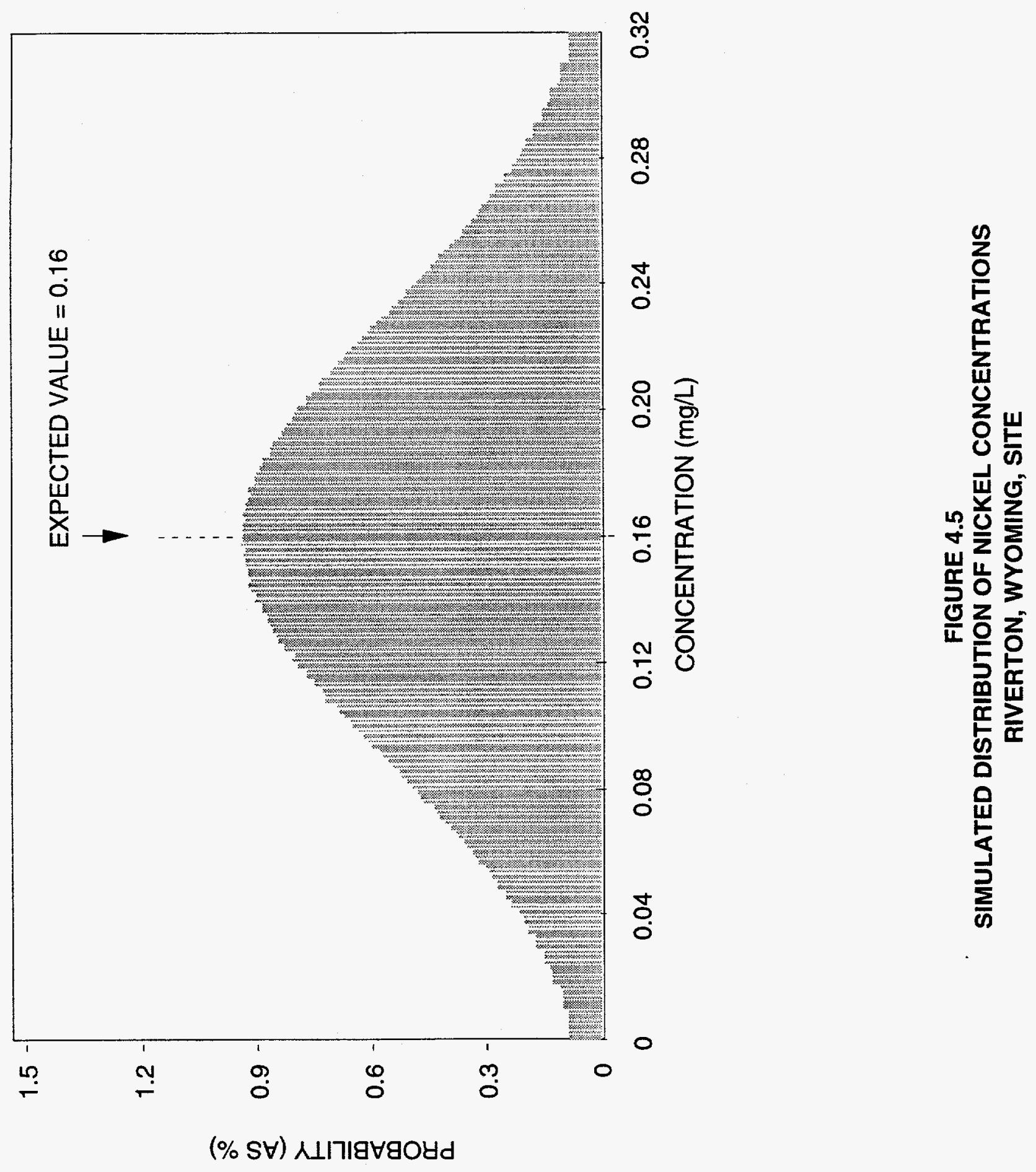


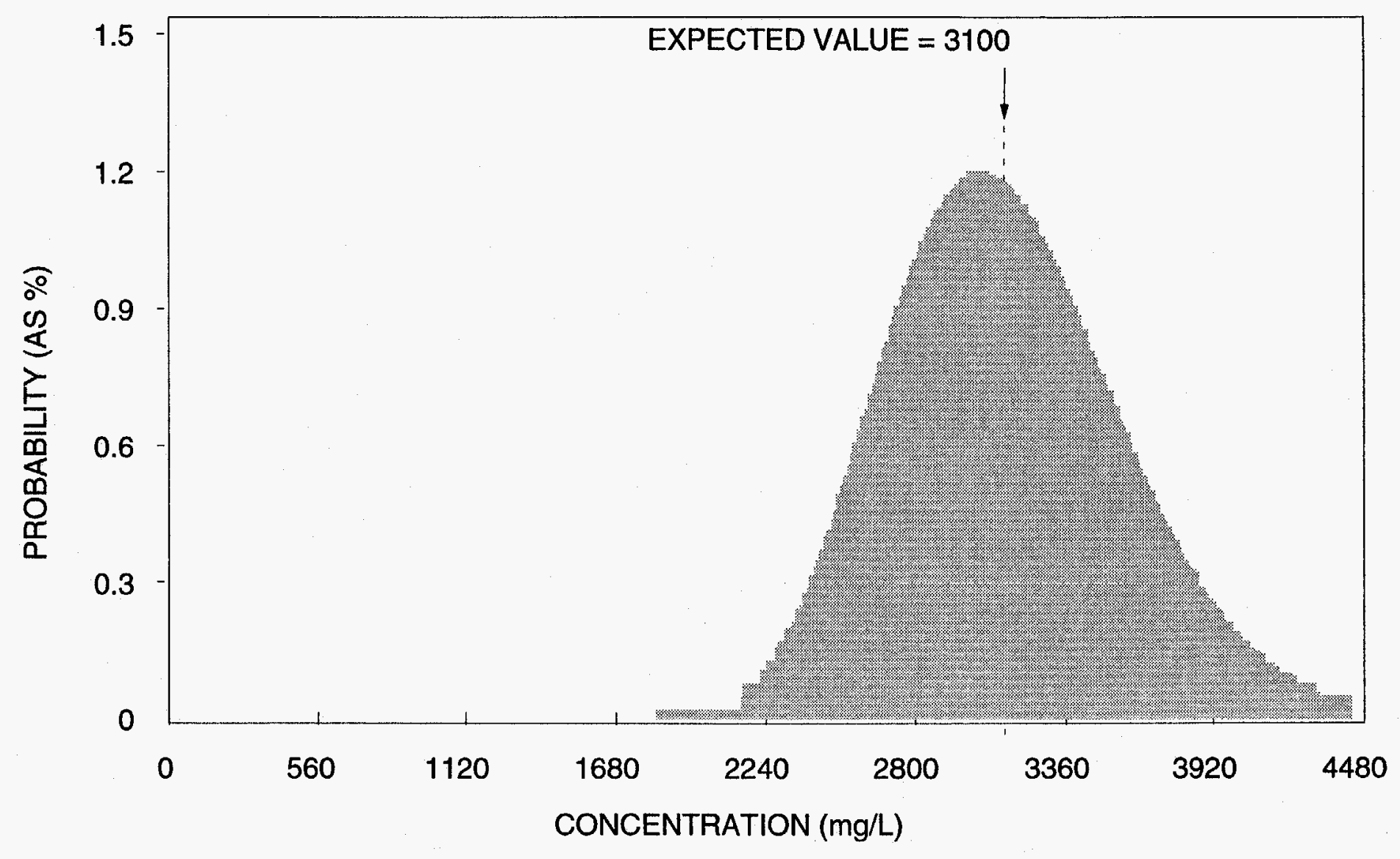

FIGURE 4.6

SIMULATED DISTRIBUTION OF SULFATE CONCENTRATIONS

RIVERTON, WYOMING, SITE 


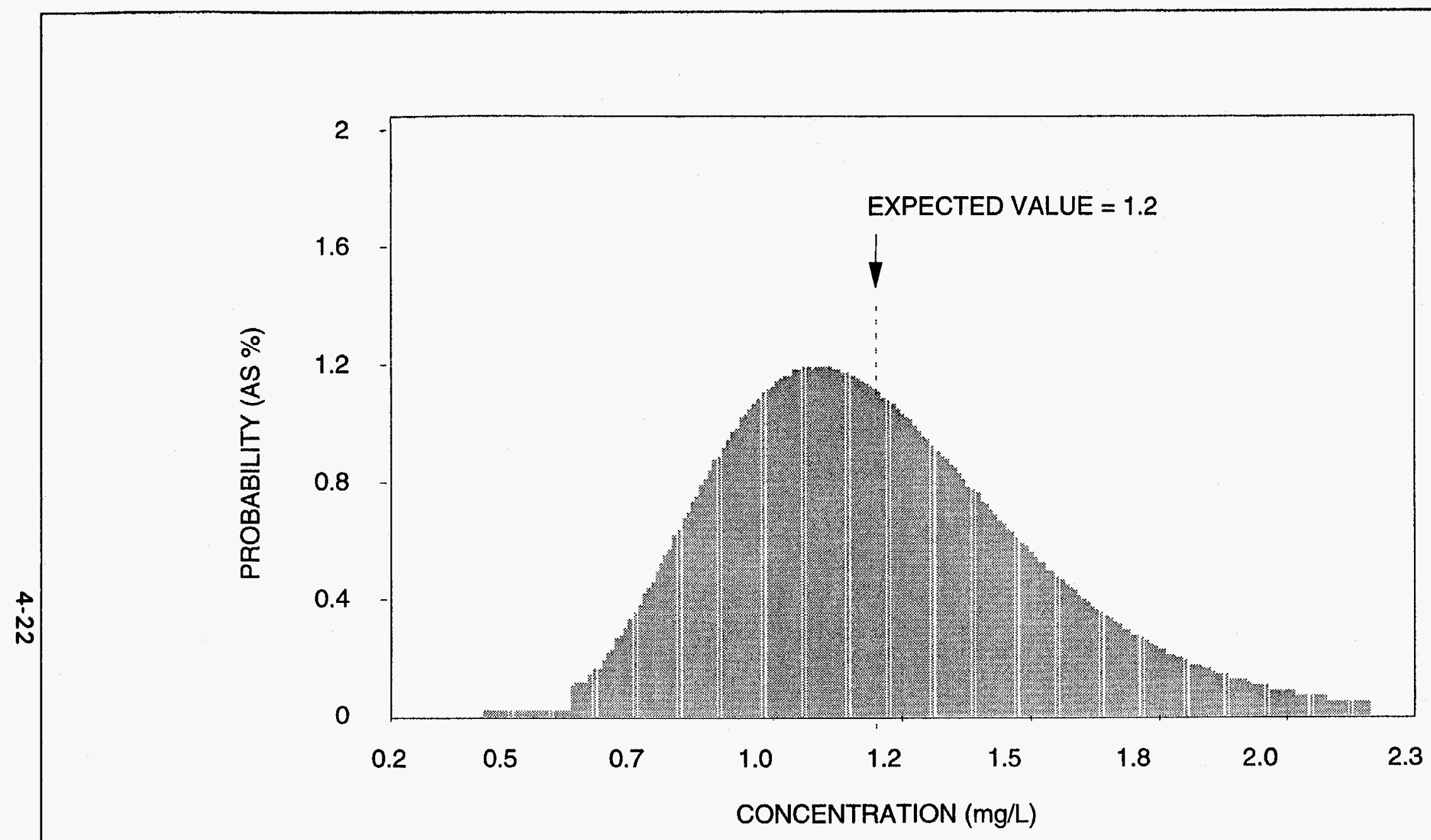

FIGURE 4.7

SIMULATED DISTRIBUTION OF URANIUM CONCENTRATIONS

RIVERTON, WYOMING, SITE 


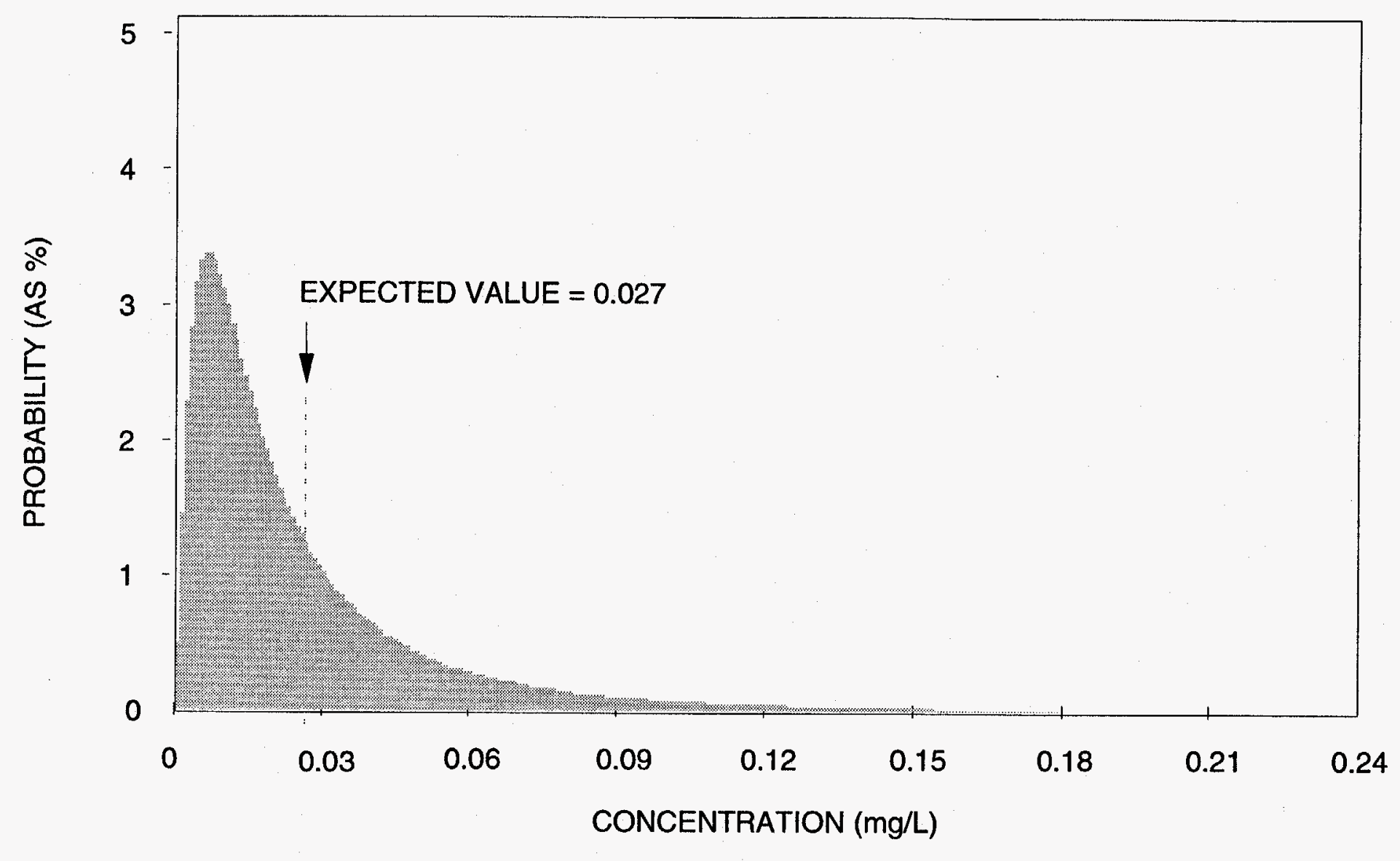

FIGURE 4.8

SIMULATED DISTRIBUTION OF VANADIUM CONCENTRATIONS

RIVERTON, WYOMING, SITE 
averaging time in the denominator; therefore, chronic daily intake is calculated as follows:

$$
\text { Intake }(\mathrm{mg} / \mathrm{kg}-\text { day })=\frac{\text { Concentration }(\mathrm{mg} / \mathrm{L}) \times \text { ingestion rate }(\mathrm{L} / \text { day })}{\text { Body weight }(\mathrm{kg})}
$$

Unlike the potential carcinogenic risk from noncarcinogens, which is calculated on average daily intake, the potential carcinogenic risk from radionuclides increases with total intake over time. Also, the body weight factor is relatively insignificant in determining risk from exposure. Intake of a radioactive carcinogen is therefore quantified as total exposure to radioactivity throughout the individual's period of residence:

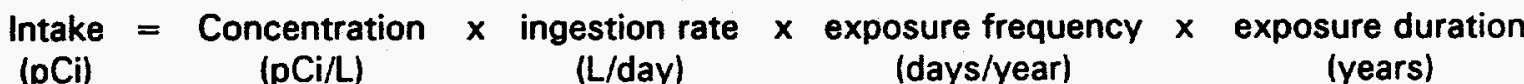

Intake of a chemical carcinogen such as arsenic is quantified using the following equation:

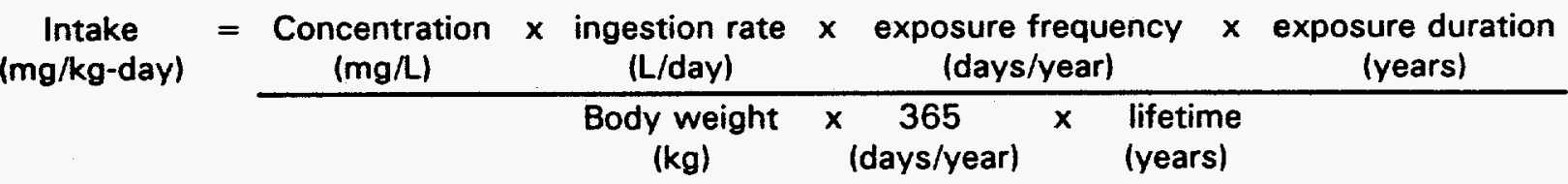

\section{Average daily intake (L/day)}

Lognormal probability distributions were used to describe variations in average daily tap water intake among members of the population (Roseberry and Burmaster, 1992). These distributions were developed from data collected during a 1977-1978 National Food Consumption Survey conducted by the U.S. Department of Agriculture. During the survey, total tap water consumption during a 3-day period was recorded for 26,081 survey participants nationwide (Figure 4.9).

\section{Exposure frequency (days per year)}

Individuals are typically exposed fewer than 365 days per year because of time away from home (e.g., vacation). Exposure frequency is expected to be higher among potential future residents of Riverton than among the United States population as a whole. However, in the absence of reliable information on this variable, exposure of 365 days per year was assumed throughout this assessment.

\section{Body weight (kg)}

Extensive data on weights of males and females, by age, were collected nationwide by the National Health and Nutrition Survey between 1976 and 1980. These data were used to develop lognormal probability distributions for 

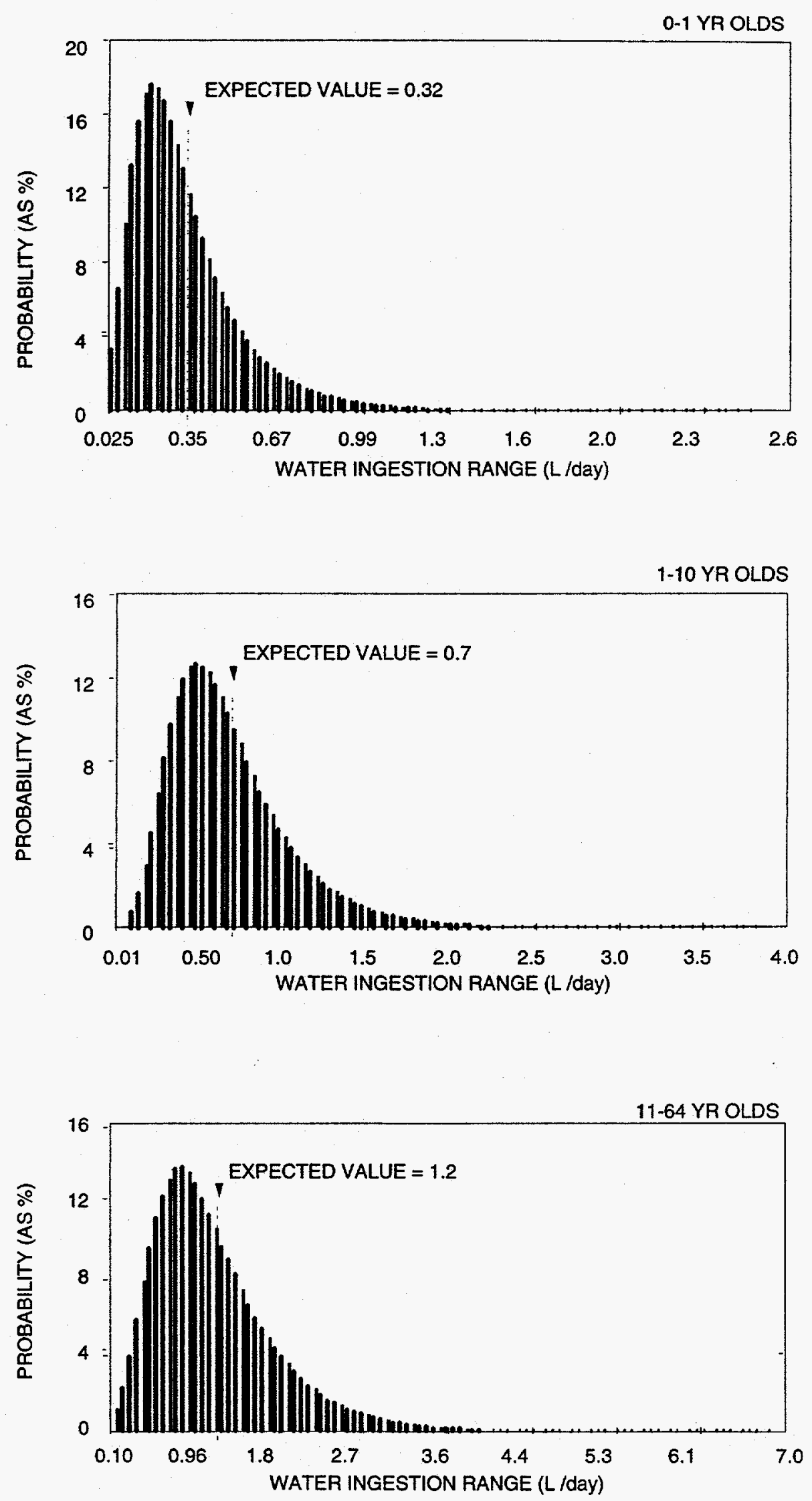

FIGURE 4.9

PROBABILITY DISTRIBUTIONS FOR TAP WATER INGESTION RATES 
body weight by age and by sex. The distributions for males and females were combined, using census data on the national ratio of males to females within each age group (Figure 4.10).

\section{Exposure duration (years)}

Distributions of total residence time (or exposure duration) were developed by Israeli and Nelson (1992) using data collected in 1985 and 1987 by the U.S. Department of Commerce, the Bureau of the Census, and the U.S. Department of Housing and Urban Development. Israeli and Nelson determined that farm residents move less frequently than urban or rural residents. To estimate exposure to carcinogens, a 30-year exposure is assumed to be reasonable for the population in the Riverton risk assessment, as this future population is expected to be primarily agricultural.

Using exposure concentration distributions and the intake parameter distributions from Section 4.3, total uranium intake distributions were derived for the three populations (Figure 4.11). These results indicate that the exposure group with the highest intake rate is children 1 to 10 . Because this group receives the highest exposure per body weight, it is used to evaluate risks from all the contaminants of potential concern except sulfate. Because infants are the most susceptible receptors to sulfate toxicity, the intake distribution for this age group is used for sulfate. The simulated intakes for noncarcinogenic contaminants of potential concern are shown in Figures 4.12 through 4.18.

\subsection{EXPOSURE ASSESSMENT UNCERTAINTIES}

In any phase of an exposure assessment, several potential sources of error can lead to underestimation or overestimation of intake. Following are the significant sources of uncertainty:

- Lack of thorough environmental sampling data.

- The assumption that the ground water contaminant source term at the site has reached a steady state and that contaminant concentrations at the exposure point will remain constant for chronic periods of exposure (generally greater than 7 years).

- The model used to estimate contaminant uptake by plants for the irrigated garden produce pathway. Plant uptake factors could vary substantially from the default estimates under the Riverton site conditions.

- The relationship between an applied and absorbed dose and the effective toxic dose for dermal absorption.

- The incidental rates of surface water and sediment ingestion from the river and other water bodies by human receptors during recreational use. 

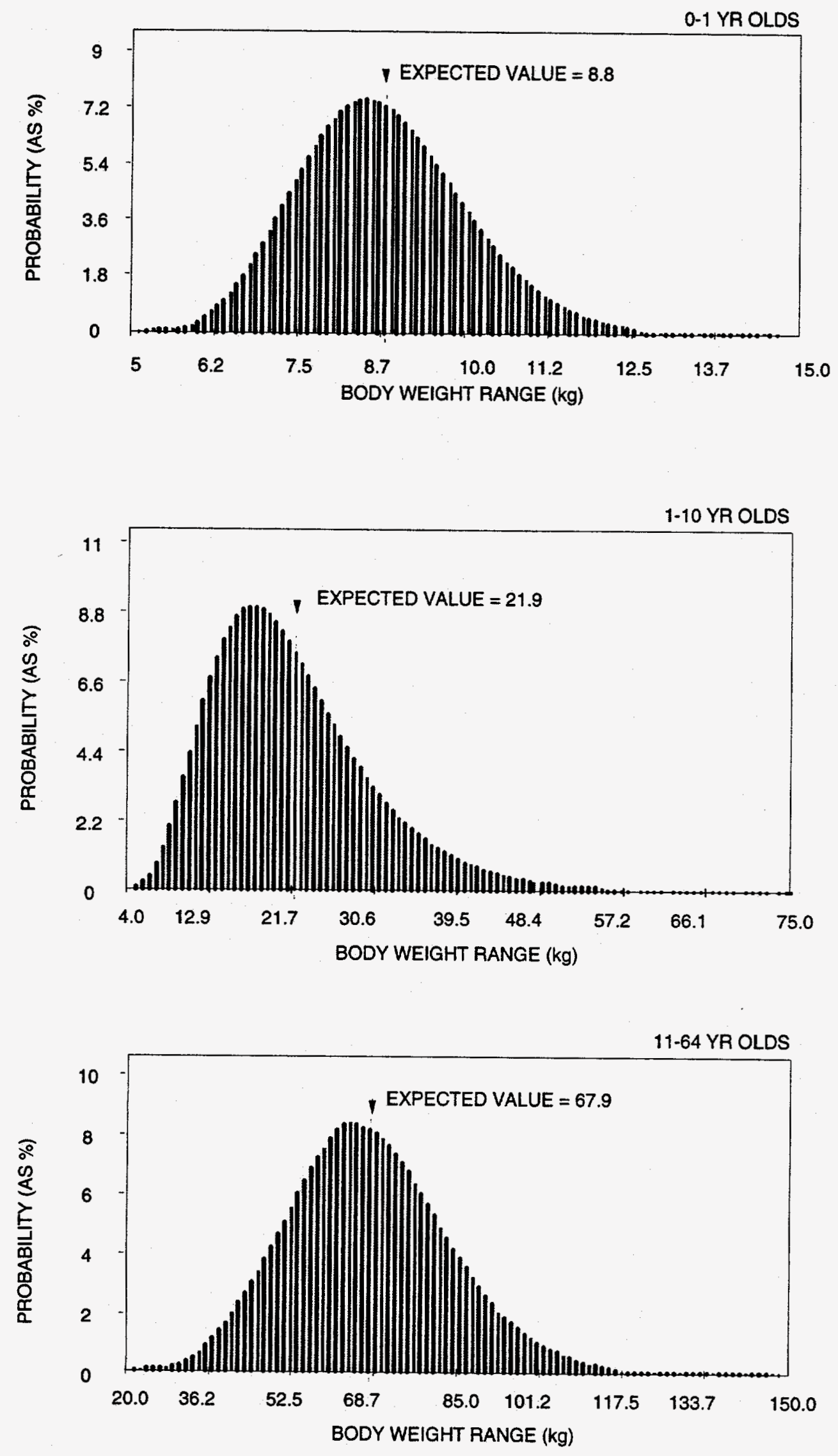

FIGURE 4.10

PROBABILITY DISTRIBUTIONS FOR BODY WEIGHT 

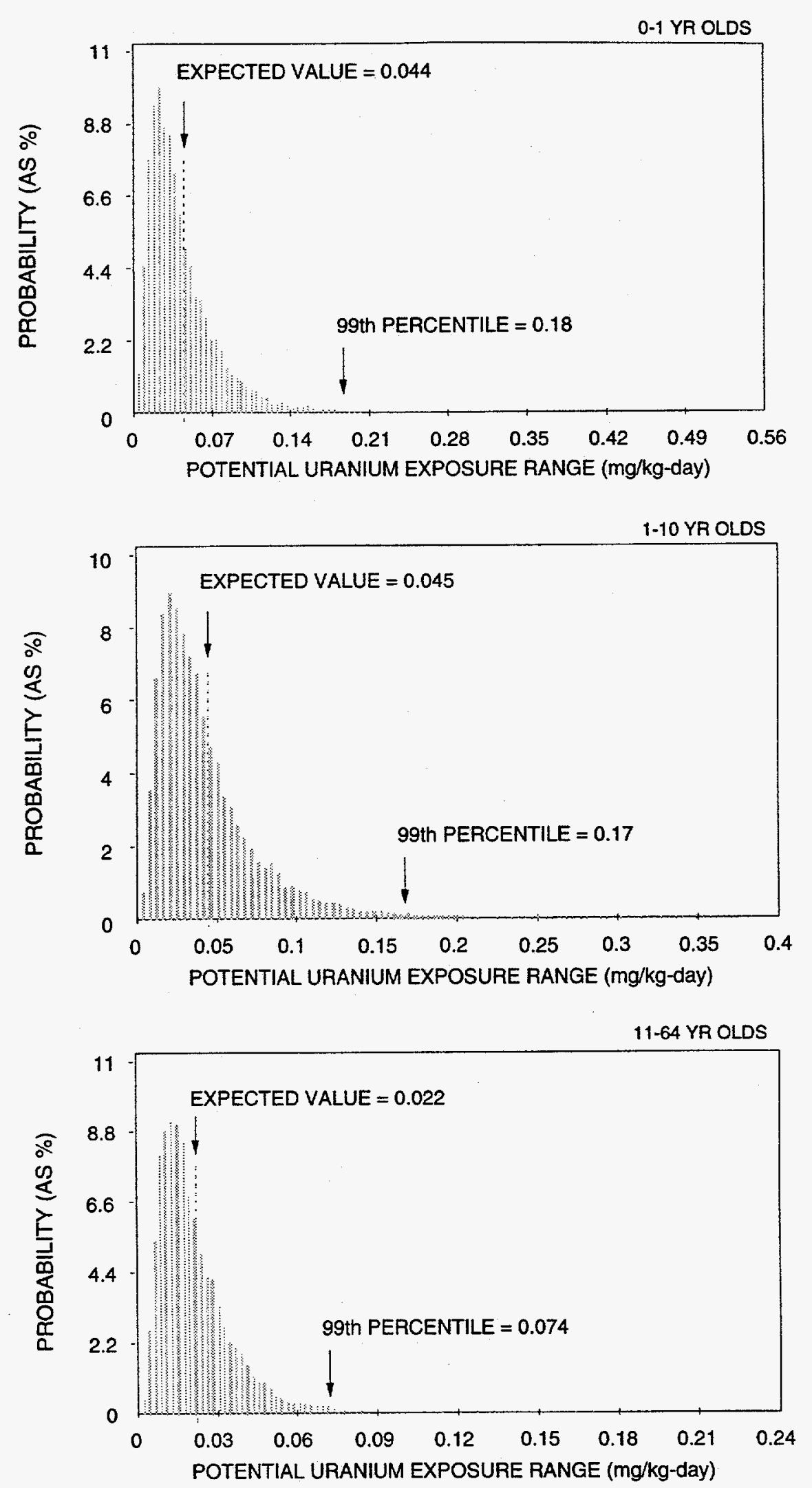

FIGURE 4.11

NOTE: HIGHEST POTENTIAL EXPOSURE OCCURS IN CHILDREN AGE 1-10 (AVERAGE POTENTIAL EXPOSURE OF $0.045 \mathrm{mg}$ URANIUM $/ \mathrm{kg}$ BODY WEIGHTIDAY).

COMPARISON OF DISTRIBUTIONS OF POTENTIAL URANIUM EXPOSURES AS A RESULT OF DRINKING CONTAMINATED GROUND WATER FOR THE THREE AGE GROUPS EXAMINED RIVERTON, WYOMING, SITE 


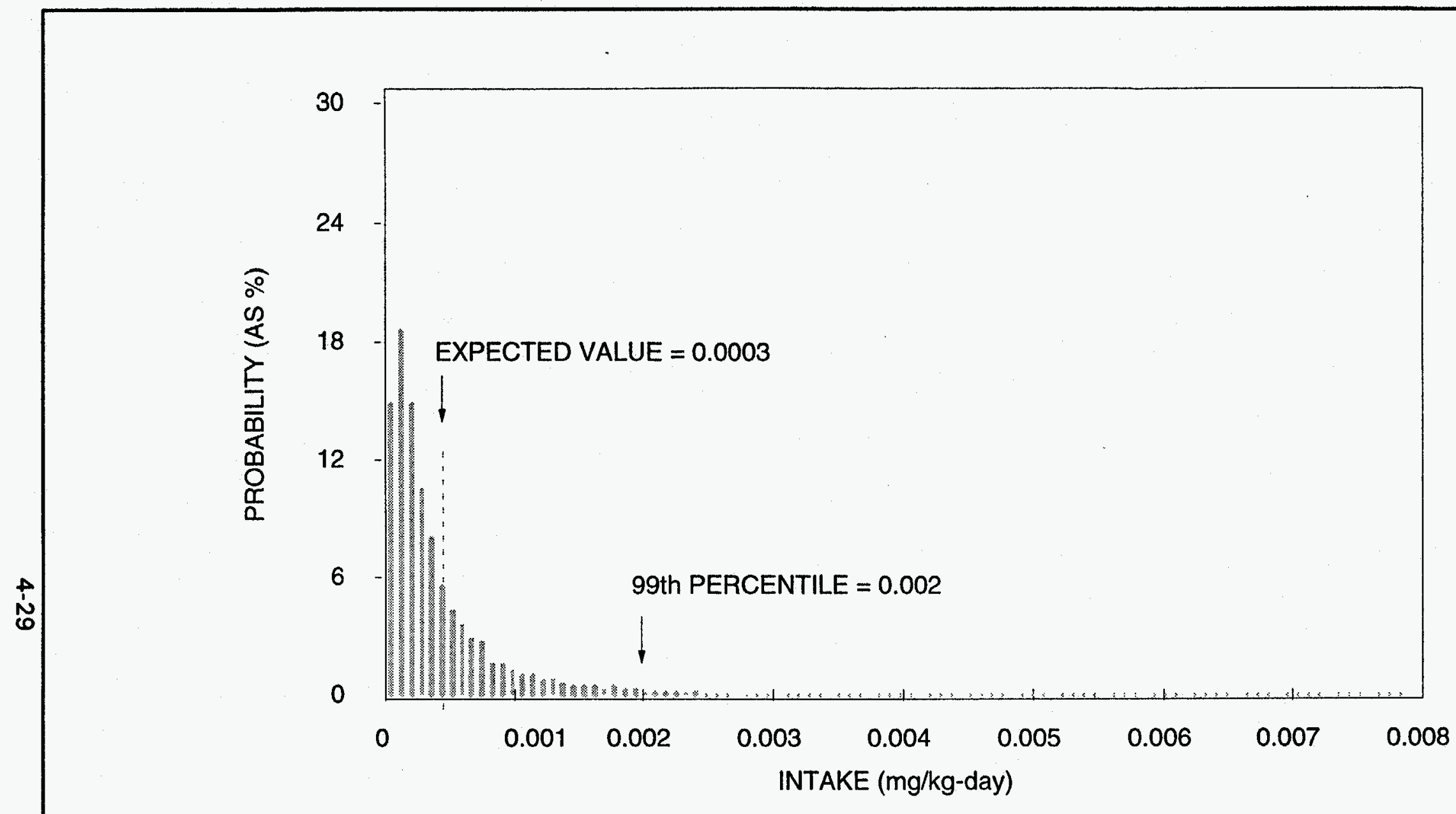

FIGURE 4.12

PROBABILITY DISTRIBUTION OF ARSENIC INTAKES FOR CHILDREN

AS A RESULT OF GROUND WATER INGESTION

RIVERTON, WYOMING, SITE 


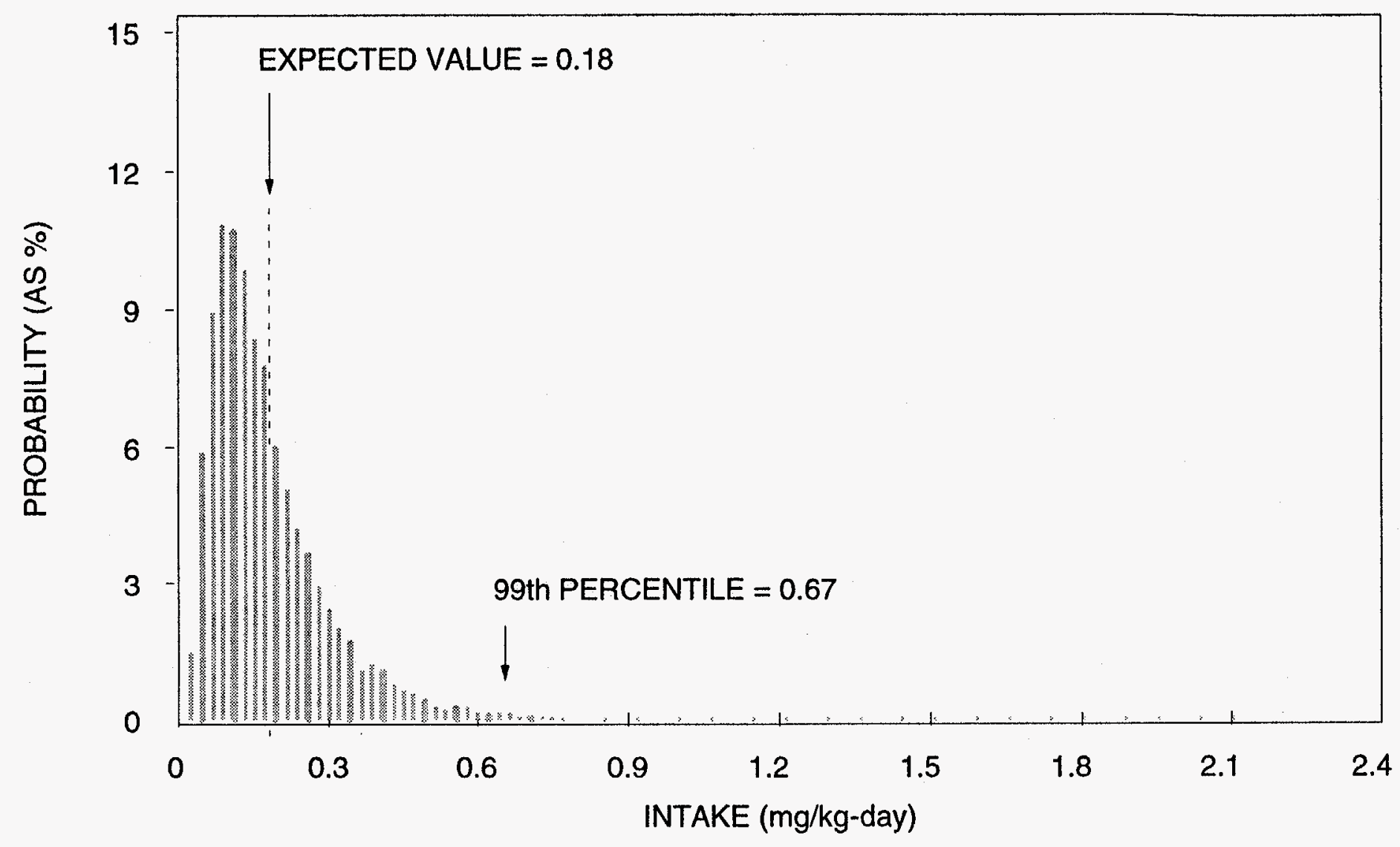

FIGURE 4.13

PROBABILITY DISTRIBUTION OF MANGANESE INTAKES FOR CHILDREN

AS A RESULT OF GROUND WATER INGESTION

RIVERTON, WYOMING, SITE 

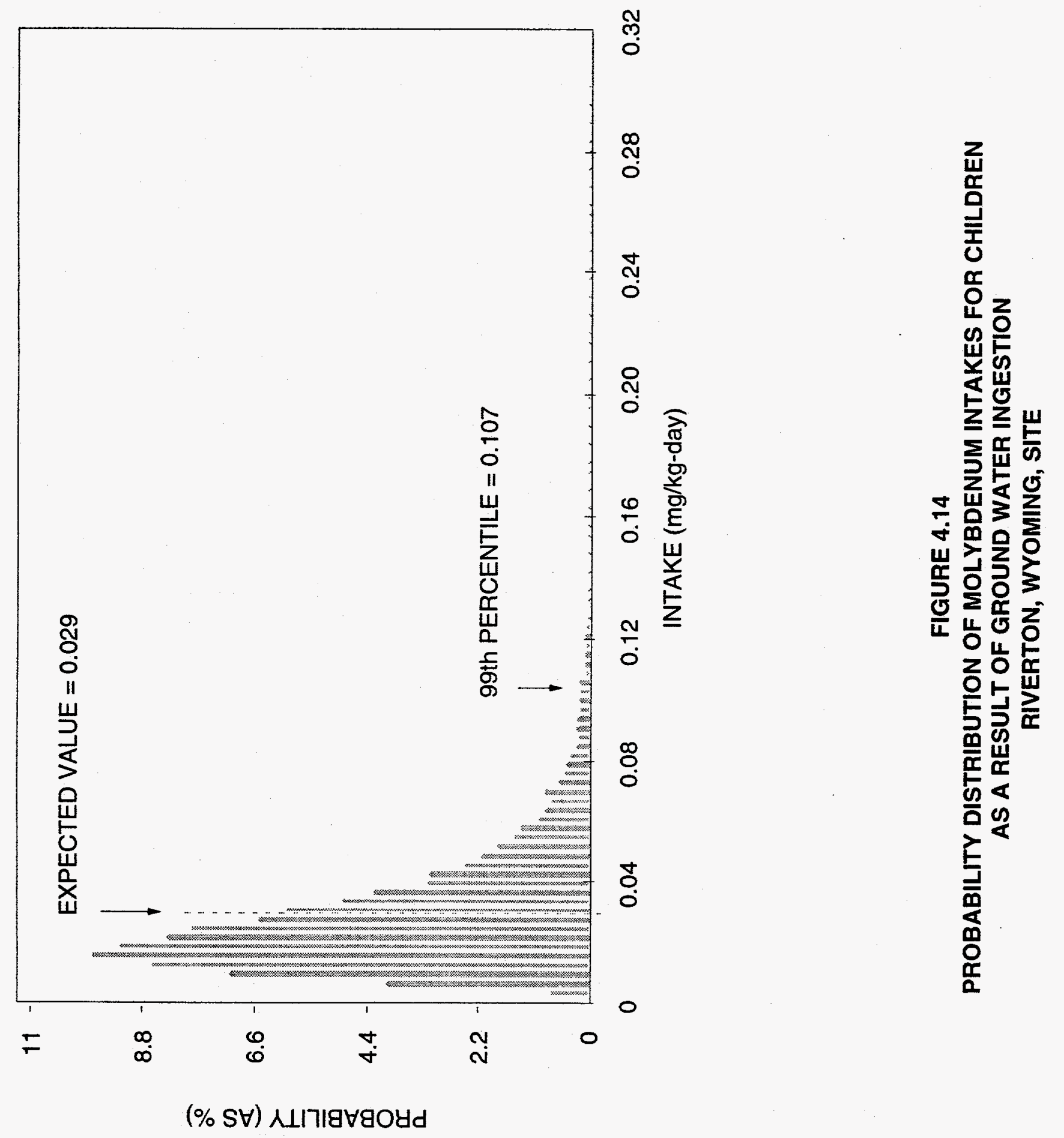


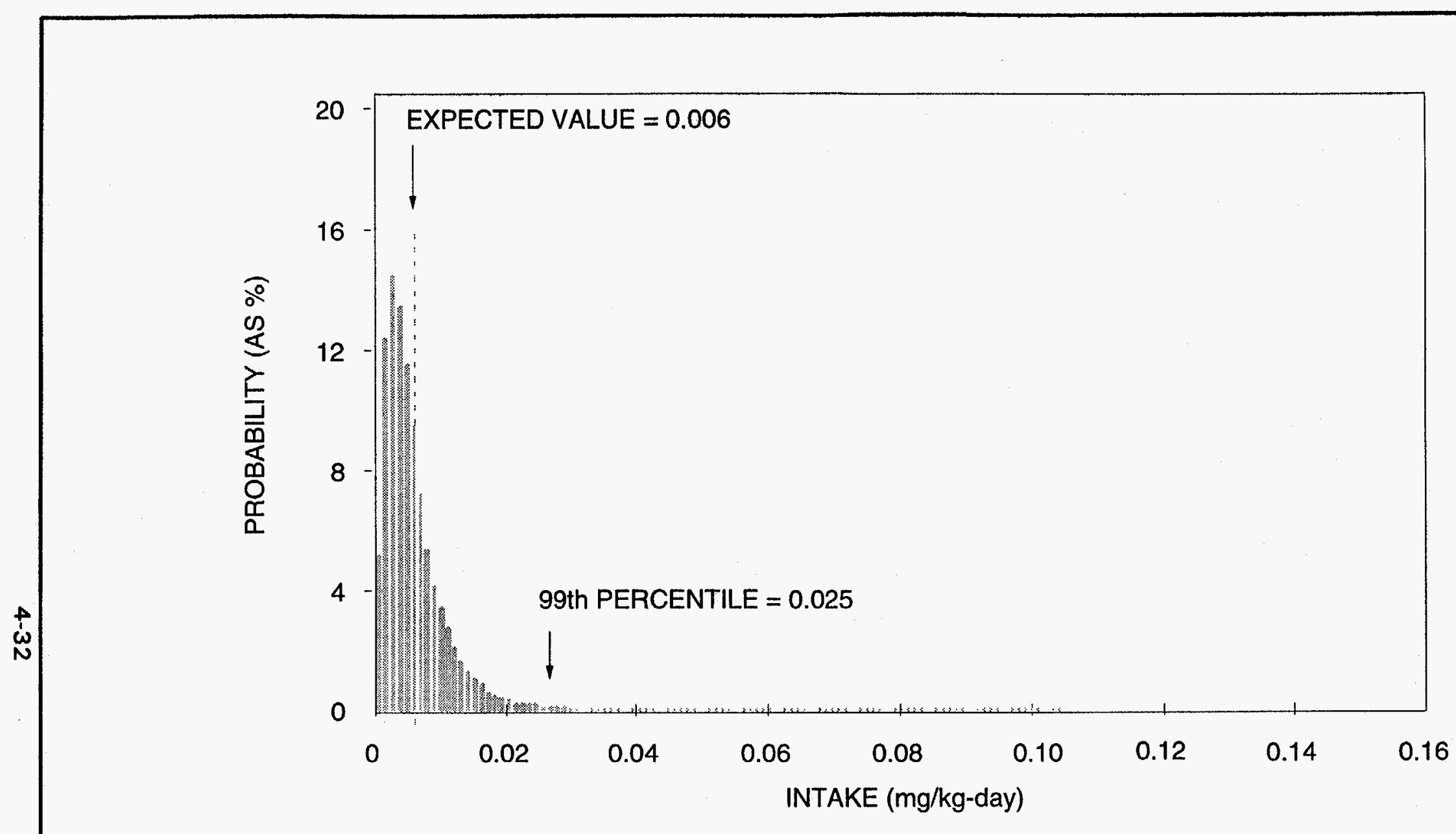

FIGURE 4.15

PROBABILITY DISTRIBUTION OF NICKEL INTAKES FOR CHILDREN

AS A RESULT OF GROUND WATER INGESTION

RIVERTON, WYOMING, SITE 


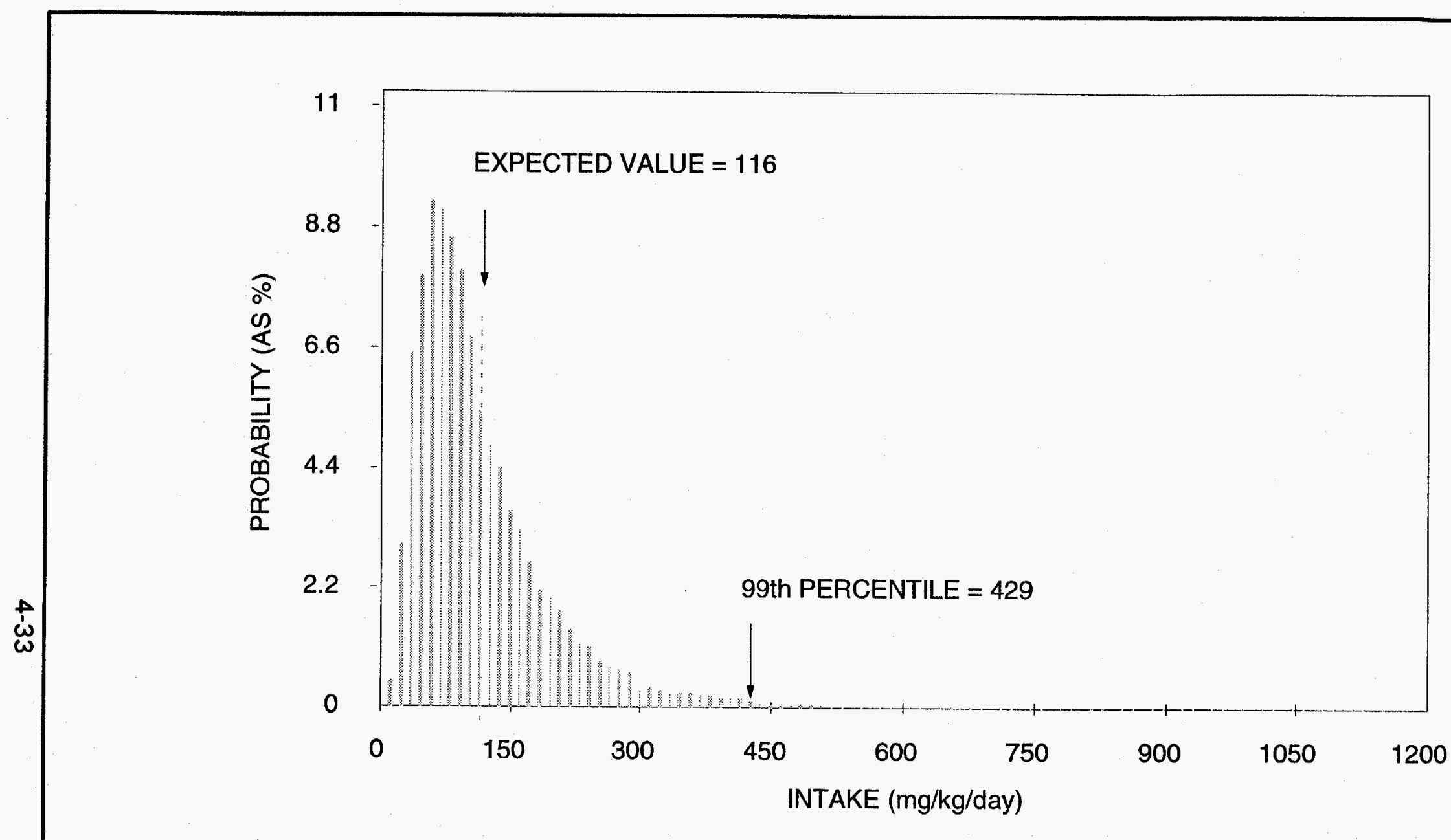

FIGURE 4.16

PROBABILITY DISTRIBUTION OF SULFATE INTAKES FOR CHILDREN

AS A RESULT OF GROUND WATER INGESTION

RIVERTON, WYOMING, SITE 

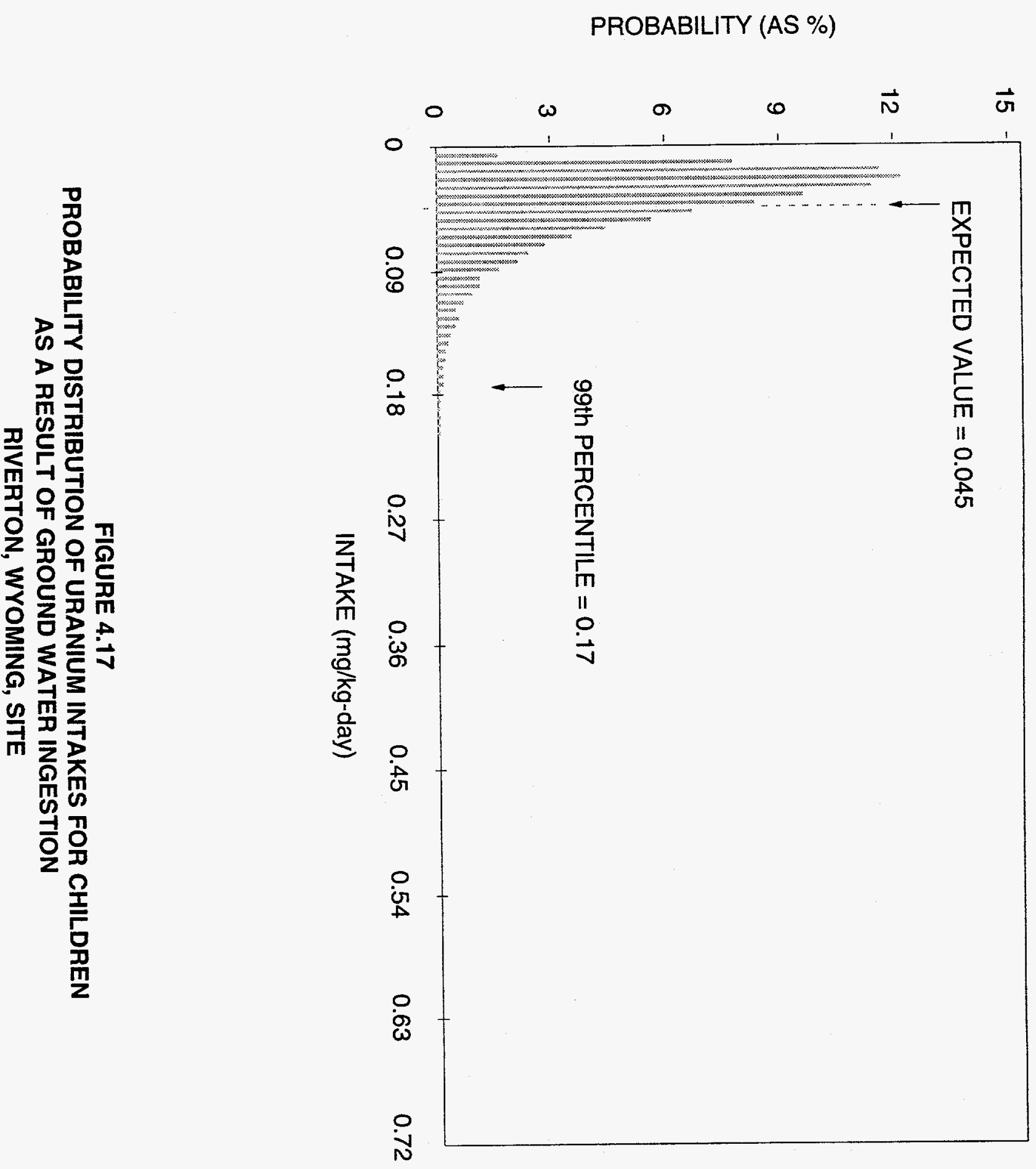


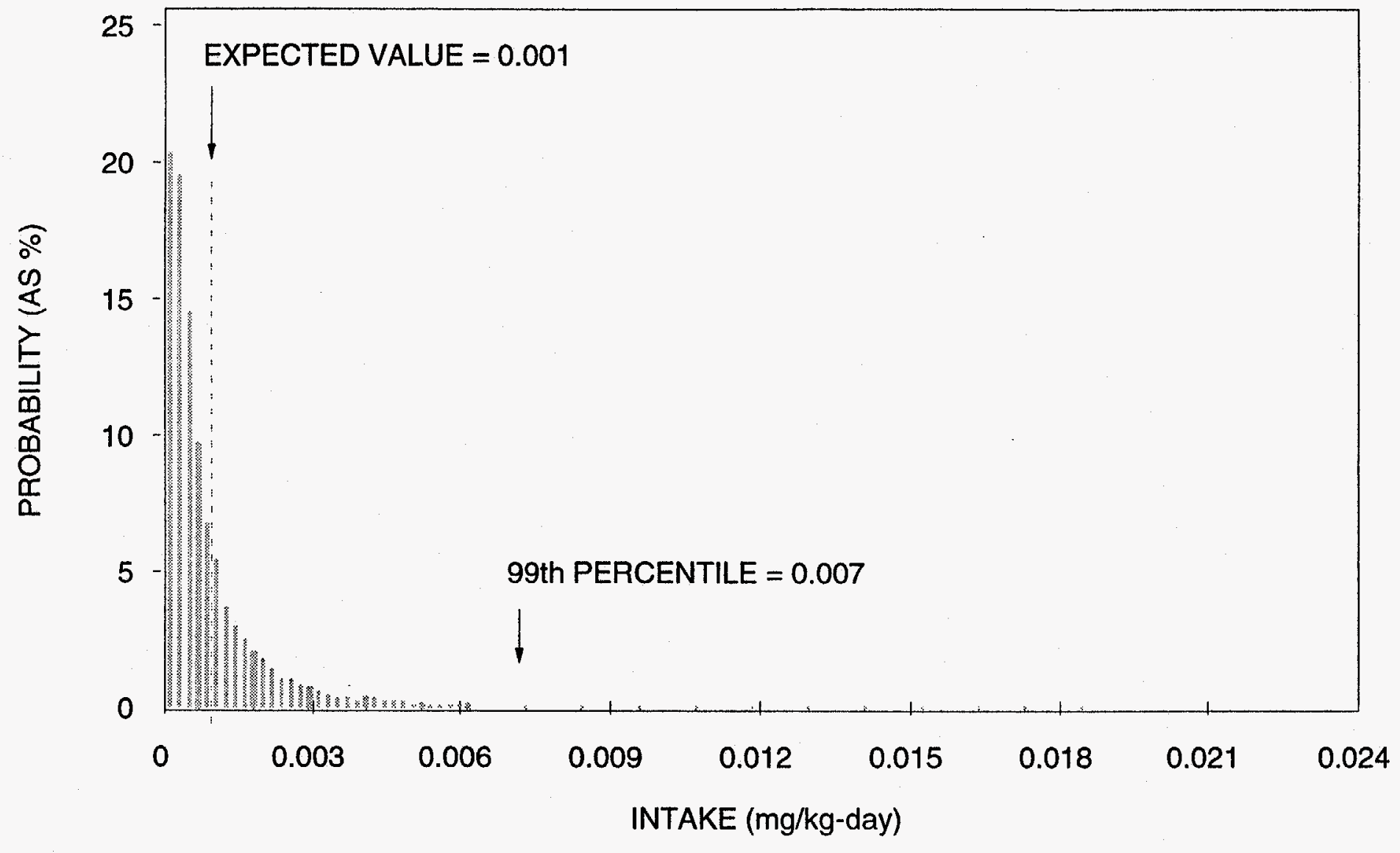

FIGURE 4.18

PROBABILITY DISTRIBUTION OF VANADIUM INTAKES FOR CHILDREN AS A RESULT OF GROUND WATER INGESTION

RIVERTON, WYOMING, SITE 
- The levels of contaminant intake by cattle and the extent of transfer to milk and muscle.

- The levels of contaminant uptake by fish.

Despite these uncertainties, probability distributions incorporating all definable sources of variability should provide a representative picture of the potential exposure range. 


\subsection{TOXICITY ASSESSMENT}

Several contaminants that could cause adverse human health and environmental effects were detected in ground water at the Riverton site. This section summarizes the toxicological effects of the chemical contaminants and the carcinogenic potentials of arsenic and the radionuclides. Source materials used to develop these toxicological profiles include the EPA's Integrated Risk Information System (IRIS); the Agency for Toxic Substances Disease Registry Toxicological Profiles, published by the Department of Health and Human Services (DHHS); the Handbook on the Toxicology of Metals (Friberg et al., 1986); and peer-reviewed scientific literature (cited when toxicity data were not available in standard review documents). By basing toxicity information on the standard review documents cited above, evaluations at UMTRA Project sites should be consistent with evaluations at sites regulated under different legislation.

The toxicity profiles presented here focus on toxicity data for drinking water in humans. Animal data, noted on the toxicity range graphs by widely spaced dotted lines, are included only when human data are not available. Uncertainty about the beginning or ending point of an exposure range producing specific toxic effects is indicated at the appropriate end of the range by closely spaced dots.

\subsection{CONTAMINANT TOXICITY SUMMARIES}

The following summaries address the basic toxicokinetics and toxicity of the seven inorganic contaminants of potential concern at Riverton (arsenic, manganese, molybdenum, nickel, sulfate, uranium, and vanadium). Although these contaminants have a wide range of toxic effects depending on the exposure levels, the following discussions focus most heavily on toxic effects observed in the exposure range most relevant to contamination at Riverton. Toxicity summaries for the radionuclide contaminants of potential concern are not presented in this section because the concentrations detected in ground water at the site, on a mass basis, are not high enough to cause any adverse noncarcinogenic effects. However, the carcinogenicity associated with these radionuclides is discussed in Section 5.2.

\subsubsection{Arsenic}

\section{Absorption}

Arsenic is effectively absorbed through inhalation and the gastrointestinal tract. Dermal absorption is negligible. In humans, approximately 80 percent of an ingested amount of dissolved inorganic trivalent (arsenite) or pentavalent arsenic (arsenate) is absorbed from the gastrointestinal tract (Pershagen and Vahter, 1979; Marafante and Vahter, 1987). 


\section{Tissue accumulation and clearance}

After absorption by the gastrointestinal tract, the bloodstream transports arsenic to most tissues. In humans as well as in most animal species, arsenite and arsenate initially accumulate in the liver, kidneys, and lungs. These tissues are rapidly cleared, but long-term arsenic retention is seen in organs rich in sulfhydryl-containing proteins, such as the hair, skin, squamous epithelium of the upper gastrointestinal tract, epididymis, thyroid, lens, and skeleton (Lindgren et al., 1982). The specific target tissue depends on the form of arsenic. Higher retention of arsenic occurs after exposure to trivalent arsenic than to the pentavalent form and tissue distribution is altered (Webb, 1966; Casarett and Doull, 1991 ).

In humans and rats, inorganic arsenic passes through the placental barrier. It has also been demonstrated to enter both cow and human milk (Marcus and Rispin, 1988).

In the human body, where methylcobalamine is a major methyl group donor in the biotransformation process, inorganic arsenic is converted to methylated compounds. It has been demonstrated that the major site of arsenic methylation is the liver (Marcus and Rispin, 1988). Trivalent arsenic is the substrate for methylation, and pentavalent arsenic must be reduced to trivalent arsenic before methylation can occur. Dimethylarsenic acid is a major metabolite found in animals and humans. Methylation results in a detoxification of inorganic arsenic (about one order of magnitude per methyl group) and increases the rate of arsenic excretion from the body.

The kidneys are the major route of inorganic arsenic excretion for humans (Ishinishi et al., 1986); only a small percentage is excreted in feces. The rate of excretion in urine varies depending on the chemical form of arsenic, the duration of exposure, and the species exposed. In humans exposed to a single low dose of arsenite, about 35 percent was excreted in urine over a period of 48 hours (Buchet et al., 1980, 1981). In the case of continuous human intake over a few days, 60 to 70 percent of the daily dose is excreted in urine (Buchet et al., 1981). Following exposure to arsenate, the limited human data available indicate an excretion rate similar to that of arsenite. Other less important routes of inorganic arsenic elimination include sweat and the skin, hair, and nails.

After oral intake of radiolabeled pentavalent arsenic, 66 percent was excreted with a half-time of 2.1 days, 30 percent with a half-time of 9.5 days, and 3.7 percent with a half-time of 38 days (Marcus and Rispin, 1988).

\section{Environmental sources of arsenic}

In nature, arsenic is ubiquitous in both inorganic and organic compounds and is primarily transported by water. In oxygenated water, arsenic occurs in a pentavalent form; under reducing conditions, the trivalent form predominates. Arsenic sedimentation in association with iron and aluminum represents a 
considerable factor in its environmental transport and deposition (Marcus and Rispin, 1988).

As a result of arsenic's widespread occurrence, the general human population is exposed to it primarily in drinking water and foodstuffs. Certain target groups are exposed to arsenic from industrial and agricultural uses. Medicinal use has also been a significant route of human exposure.

Drinking water usually contains a few micrograms of arsenic, predominantly as inorganic salts in the trivalent and pentavalent states (WHO, 1981). However, concentrations of up to $1.1 \mathrm{mg} / \mathrm{L}$ in drinking water have been reported in Chile, Argentina, Taiwan, the United States, and the United Kingdom (WHO, 1981).

Certain foodstuffs contain appreciable amounts of arsenic. The concentration of arsenic in fish and seafood, particularly shellfish, is generally one or two orders of magnitude higher than in other foods. Wine and mineral waters can contain several hundred micrograms of arsenic per liter (Crecelius, 1977; WHO, 1981).

\section{Toxicity of arsenic}

Levels of exposure associated with acute toxicity vary with arsenic's form of valence. Trivalent arsenicals (arsenites) are generally more toxic than pentavalent (arsenates) (Morrison et al., 1989), and inorganic arsenic compounds are more toxic than organic (Shannon and Strayer, 1989). Based on geochemical models for the Riverton site, arsenic exists primarily in the pentavalent form in ground water (Table 3.5). For arsenic trioxide, the reported estimated acute oral lethal dose in humans ranges from 70 to $300 \mathrm{mg}(1$ to $4 \mathrm{mg} / \mathrm{kg}$ ) (EPA, 1984). Acute exposure to inorganic arsenic compounds may lead to severe inflammation of the gastrointestinal tract, encephalopathy, and acute renal failure.

Chronic arsenic intoxications result from long-term exposure to even small doses and are frequently caused by arsenic in drinking water or food. Skin changes leading to skin cancer are commonly seen in populations exposed to high concentrations of arsenic in drinking water. Endemic arsenic poisoning is seen in Cordoba, Argentina, where the concentration of arsenic in drinking water ranges from 0.9 to $3.4 \mathrm{mg} / \mathrm{L}$ (equivalent to 0.026 to $0.097 \mathrm{mg} / \mathrm{kg}$-day). Certain areas of Taiwan also have a naturally high concentration of arsenic in their drinking water that causes blackfoot disease, a peripheral extremity vascular disorder resulting in gangrene. A dose-response relationship between the incidence of blackfoot disease and the duration of exposure to arsenic has been documented (Tseng, 1977).

Taiwanese studies of more than 40,000 people exposed to arsenic in drinking water at daily intakes ranging from 1.4 to $6.3 \mathrm{mg}$ reported hyperpigmentation, hyperkeratosis, and skin cancer with prevalence of 7.1 percent, 18.4 percent, and 1.1 percent, respectively. 
A progressive increase in chronic oral arsenic ingestion produces systemic effects including 1) arterial thickening in children and adults $(0.02 \mathrm{mg} / \mathrm{kg}$-day); 2) neurological symptoms including peripheral neuropathy $(0.04 \mathrm{mg} / \mathrm{kg}$-day);

3) fibrosis of the liver $(0.05 \mathrm{mg} / \mathrm{kg}$-day); and 4) cirrhosis of the liver (0.08 mg/kg-day) (DHHS, 1993a).

Teratogenic effects of arsenic compounds administered intravenously or intraperitoneally at high doses have been demonstrated in laboratory animals only (Ferm, 1971; Hood, 1972; EPA, 1984). Teratogenic effects, or birth defects, are defined as effects resulting in structural or functional anomalies in live offspring.

Certain characteristics of exposed human populations may influence arsenic toxicity at high exposure levels. Genetic dispositions (rapid versus poor acetylators) and a protein-deficient diet may decrease the methylation of arsenic. This can result in an increased deposition of the element in the target organs (e.g., the lungs or skin).

The EPA has classified inorganic arsenic as a Group $A$ (human) carcinogen (EPA, 1994), based on the occurrence in populations exposed primarily through inhalation of increased lung cancer mortality and of increased skin cancer in populations exposed through drinking water. The EPA is currently reviewing the cancer slope factor in light of recent data suggesting arsenic ingestion may result in increased cancers in internal organs as well as skin cancers. The health effects from exposure to arsenic as a function of dose are summarized in Figure 5.1.

\subsubsection{Manganese}

\section{Absorption}

Absorption of manganese following ingestion is controlled homeostatically: the rate depends both on the amount ingested and on levels of manganese in the tissues. For adult humans, approximately 3 to 4 percent of dietary manganese is absorbed (Saric, 1986). Manganese can be absorbed following exposure by inhalation, ingestion, or dermal contact. In humans, available data indicate that only 3 percent of an ingested dose of manganese chloride is absorbed (Mena et al., 1969). The rate of absorption is influenced by iron and other metals. In states of iron deficiency, manganese is actively absorbed from the intestine. Individuals with anemia can absorb more than twice the percentage of an ingested dose. However, in states of excess iron, manganese is absorbed by diffusion only (Saric, 1986). High levels of dietary calcium and phosphorus have been shown to increase the requirements for manganese in several species (Lönnerdal et al., 1987). 


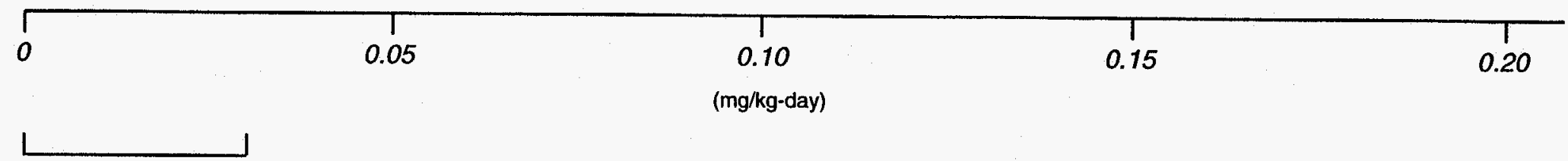

BACKGROUND INTAKE LEVELS

$\triangle$ ORAL REFERENCE DOSE $=0.0003 \mathrm{mg} / \mathrm{kg}$-day

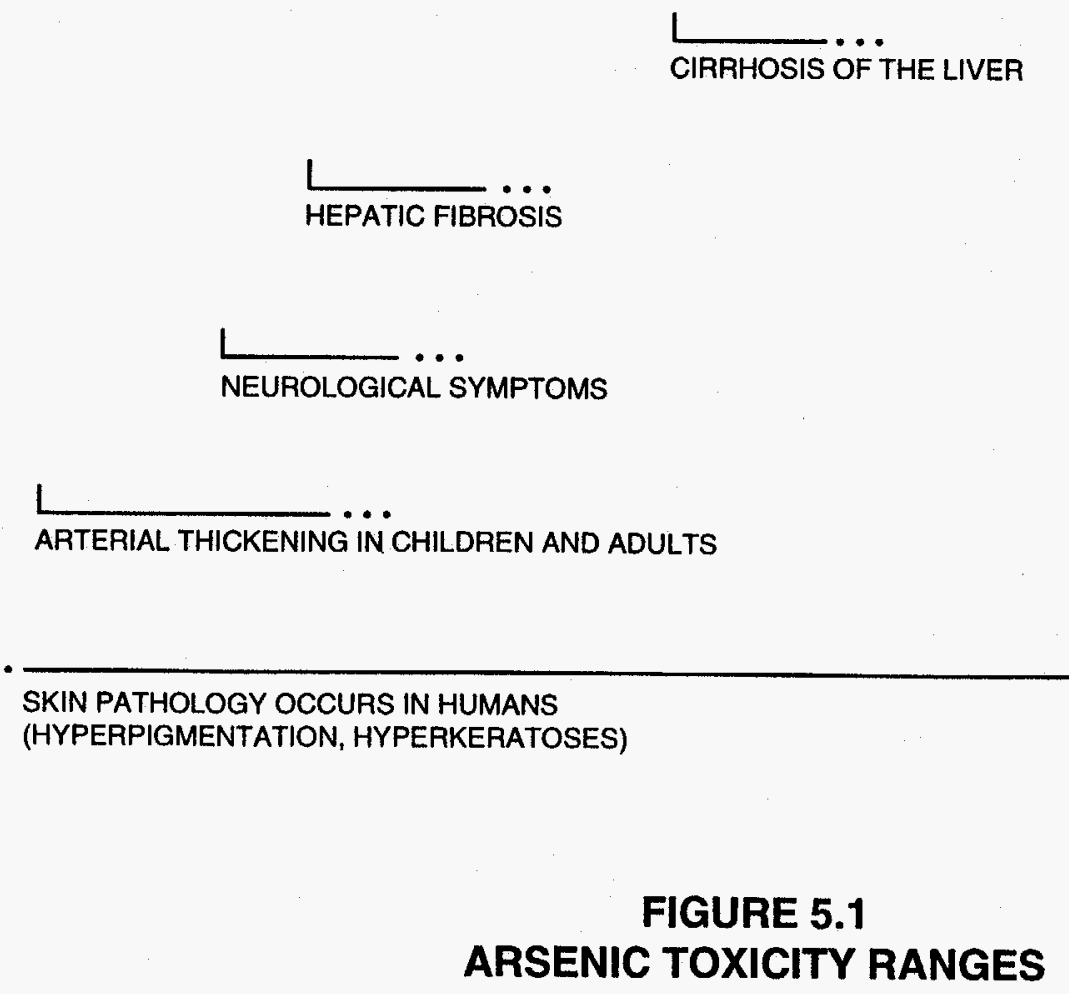




\section{Tissue accumulation and clearance}

Manganese is widely distributed throughout the body but is highly concentrated in the liver, kidneys, and to a lesser extent in the hair. The biological half-time in humans is 2 to 5 weeks, depending on body stores. Manganese readily crosses the blood-brain barrier and is more slowly cleared from the brain than from other tissues (Goyer, 1991). Normal concentrations in the brain are low, but the half-time in the brain is longer and the metal may accumulate there with excessive absorption (National Research Council, 1973).

Absorbed manganese is rapidly cleared from the blood and concentrates in mitochondria. Initial concentrations are greatest in the liver. Manganese penetrates the placental barrier in all species and is more uniformly distributed in fetal than in adult tissues. It is also secreted into milk.

Absorbed manganese is almost totally secreted in bile and reabsorbed from the intestine as necessary to maintain body levels. At excessive exposure levels, other gastrointestinal routes may participate. Excess manganese is eliminated in the feces; urinary excretion is negligible (Goyer, 1991; Saric, 1986).

\section{Environmental sources of manganese}

On the whole, food is the major source of manganese for humans. The highest manganese concentrations are found in plants, especially wheat and rice. Drinking water generally contains less than $0.1 \mathrm{mg} / \mathrm{L}$. Manganese levels in soil range from 1 to $7000 \mathrm{mg} / \mathrm{kg}$, with an average of 600 to $900 \mathrm{mg} / \mathrm{kg}$. Mining and natural geological background variation can contribute to this variability. Manganese bioaccumulates in marine mollusks up to 12,000-fold, and there is evidence for toxic effects in plants (phytotoxicity) and plant bioaccumulation. The Illinois Institute for Environmental Quality has recommended a criterion of 1 to $2 \mathrm{mg} / \mathrm{kg}$ for manganese in soil and $200 \mathrm{mg} / \mathrm{kg}$ in plants (Saric, 1986).

Variations in manganese intake can be explained to a large extent by differences in nutritional habits. Intake in populations whose main food sources are cereals and rice will be higher than in areas where meat and dairy products make up a larger part of the diet. The average daily intake has been estimated between 2.0 and $8.8 \mathrm{mg} /$ day 10.03 and $0.13 \mathrm{mg} / \mathrm{kg}$-day) (EPA, 1994), but intakes as high as $12.4 \mathrm{mg}$ (about $0.2 \mathrm{mg} / \mathrm{kg}$-day) have been reported in countries with high cereal intake (Saric, 1986).

Drinking water generally results in an intake of less than $0.2 \mathrm{mg} 10.003$ $\mathrm{mg} / \mathrm{kg}$-day), although some mineral waters can increase this amount more than threefold (Saric, 1986). One study from Greece reported drinking water concentrations of manganese in excess of $2 \mathrm{mg} / \mathrm{L}$, which would result in daily intakes in the range of 0.06 to $0.07 \mathrm{mg} / \mathrm{kg}$-day (EPA, 1994). 


\section{Toxicity of manganese}

Manganese is an essential nutrient. Estimated safe and adequate daily dietary intakes for adults range from 0.03 to $0.07 \mathrm{mg} / \mathrm{kg}$-day (Saric, 1986). The EPA no-observed-adverse-effect level (NOAEL) for drinking water is set at $0.005 \mathrm{mg} / \mathrm{kg}$-day, while the lowest-observed-adverse-effect level (LOAEL) for drinking water sources is $0.06 \mathrm{mg} / \mathrm{kg}$-day. The EPA RfD for drinking water is $0.005 \mathrm{mg} / \mathrm{kg}$-day. The RfD for food ingestion is $0.14 \mathrm{mg} / \mathrm{kg}$-day. There is some indication that manganese in drinking water is more bioavailable, or more readily absorbed, than manganese in dietary food sources. This would result in toxic effects with lower ingested doses of manganese in drinking water than in food (EPA, 1994).

Inhalation of manganese in industrial settings has provided the largest source of data on chronic manganese toxicity. These data indicate that excess manganese can result in a central nervous system disorder that causes irritability, difficulty in walking, speech disturbances, and compulsive behavior like running, fighting, or singing. Symptoms of continued exposure include a mask-like freezing of the face, retropulsion or propulsion, and a Parkinson-like syndrome. The condition reverses slowly when manganese exposure ceases. Metal chelating agents are ineffective in treatment, but L-dopa has been effective in treatment (Goyer, 1991), suggesting that manganese produces a functional deficit in the central nervous system.

Limited information is available on the effects of manganese ingestion. Because effects from drinking water seem to differ from those from food sources, only studies on water consumption will be considered here. A Japanese study of 25 people drinking well water with manganese concentrations of $14 \mathrm{mg} / \mathrm{L}$ $(0.4 \mathrm{mg} / \mathrm{kg}$-day estimated intake) reported symptoms of intoxication including a mask-like face, muscle rigidity and tremors, and mental disturbances. There were two cases ( 8 percent) of death among intoxicated people. A Greek study of over 4000 individuals drinking water with manganese concentrations varying from 0.081 to $2.3 \mathrm{mg} / \mathrm{L}$ (estimated intake at $2 \mathrm{~L} /$ day for a $70-\mathrm{kg}$ individual range from 0.002 to $0.07 \mathrm{mg} / \mathrm{kg}$-day) showed varying degrees of neurological effects in individuals drinking from 0.007 to $0.07 \mathrm{mg} / \mathrm{kg}$-day, but no effects in individuals drinking less than $0.005 \mathrm{mg} / \mathrm{kg}$-day (Kondakis et al., 1989).

The chemical form of manganese has complex effects on its toxicity. Although more soluble forms are more readily absorbed from the gastrointestinal tract, they also appear to be more rapidly cleared. Exposure to insoluble forms results in lower manganese absorption but also in higher chronic tissue levels and, therefore, greater toxicity (EPA, 1994). Only limited information is available on the effects of various forms of manganese.

Few data are available on manganese toxicity in infants, but it is likely that infants will be more susceptible to toxicity due to greater absorption and greater penetration into the central nervous system (EPA, 1994; Saric, 1986). 
The toxicity of manganese is summarized in Figure 5.2.

\subsubsection{Molybdenum}

\section{Absorption}

Absorption of molybdenum in the gastrointestinal tract depends on the species of the metal. Both inorganic and hexavalent forms such as molybdenum trioxide, sodium molybdate, and ammonium molybdate are readily absorbed from both food and water, whereas molybdenite is not. Human absorption rates of 40 percent to 70 percent have been observed for molybdenum (Tipton and Cook, 1963; Robinson et al., 1973; Alexander et al., 1974).

\section{Tissue accumulation and clearance}

In humans, the highest concentrations of molybdenum occur in the liver, kidneys, and adrenals (Casarett and Doull, 1991). With normal dietary intake, molybdenum levels in the body slowly increase until approximately age 20 , then begin to decline steadily. The principal route of excretion in humans is in the urine. Human studies indicate the biological half-life in humans is considerably longer than in animals and may be as long as 2 weeks (Rosoff and Spencer, 1964).

\section{Environmental sources of molybdenum}

Molybdenum occurs naturally in combination with other metals, including uranium, lead, iron, cobalt, and calcium. Native soil concentrations can vary by as much as two orders of magnitude, from $0.1 \mathrm{mg} / \mathrm{kg}$ to $10 \mathrm{mg} / \mathrm{kg}$, leading to large variations in the molybdenum concentrations in plant materials. Natural concentrations in ground water have been reported from $0.00011 \mathrm{mg} / \mathrm{L}$ to $0.0062 \mathrm{mg} / \mathrm{L}$. Human dietary intake of molybdenum has been estimated at 0.05 to $0.24 \mathrm{mg} /$ day $(0.0007$ to $0.003 \mathrm{mg} / \mathrm{kg}$-day). The contribution of drinking water is estimated to range from 0 percent to 95 percent. The nutritional range of intake for molybdenum is from 0.0015 to 0.0054 $\mathrm{mg} / \mathrm{kg}$-day. No symptoms of molybdenum deficiency have been reported in humans. Nonetheless, molybdenum is an essential trace element that functions as a necessary constituent of several enzymes, including xanthine oxidase (which is involved in the metabolism of uric acid) and nitrate reductase (Friberg et al., 1986).

\section{Toxicity of molybdenum}

Acute toxic effects of molybdenum have not been reported. No adverse health effects have been reported with chronic intake of less than $0.008 \mathrm{mg} / \mathrm{kg}$-day of molybdenum. The primary toxicity of molybdenum is related to its interactions with copper and sulfur, leading to altered excretion patterns for these elements. Increased levels of molybdenum also increase the levels of xanthine oxidase, 


\begin{tabular}{|c|c|c|c|c|c|c|c|c|}
\hline & 1 & $T$ & $T$ & 1 & $T$ & $T$ & $T$ & 1 \\
\hline 0 & 0.25 & 0.5 & 0.75 & $\begin{array}{c}1.0 \\
\text { (mg/kg-day) }\end{array}$ & 1.25 & 1.5 & 1.75 & 2.0 \\
\hline
\end{tabular}

\section{$\perp$ BACKGROUND DRINKING WATER INTAKE}

\section{L}

DIETARY INTAKE FROM FOOD

$\triangle$ EPA RfD - DRINKING WATER (0.005 mg/kg-day)

... - . .

EARLY NEUROLOGICAL SYMPTOMS

PARKINSON-LIKE EFFECTS

FIGURE 5.2

MANGANESE TOXICITY RANGES 
which is responsible for the production of uric acid. High levels of uric acid can accumulate in joints and lead to symptoms of gout and other joint disorders.

Intake of 0.008 to $0.022 \mathrm{mg} / \mathrm{kg}$-day of molybdenum can produce mineral imbalances as a result of increased copper excretion. Excretion of copper has been reported to double with molybdenum intakes at the upper end of this range. Copper is an essential nutrient important in many metabolic pathways, including the synthesis and function of hemoglobin. A copper deficiency resulting from excess excretion will impair the oxygen-carrying capacity of the blood, and severe copper deficiencies can lead to hypochromic microcytic anemia. In humans, gout-like symptoms and joint deformities have been reported in regions of Russia where elevated soil concentrations of molybdenum and subsequent increased molybdenum concentrations in food would lead to molybdenum intakes in the range of 0.14 to $0.21 \mathrm{mg} / \mathrm{kg}$-day. The health effects of molybdenum are summarized in Figure 5.3 as a function of dose.

\subsubsection{Nickel}

\section{Absorption}

Absorption studies in humans report that 27 percent of inorganic nickel (administered as nickel sulfate) was absorbed when it was administered in drinking water, whereas only 0.7 percent was absorbed when it was given in food. In a separate study, the bioavailability of nickel, as measured by serum nickel levels, increased by $80 \mu \mathrm{g} / \mathrm{L}$ after 3 hours in fasting individuals who ingested nickel sulfate in drinking water, but was not elevated in individuals who ingested nickel in food (DHHS, 1993b). Other human studies show that less than 10 percent of ingested nickel is generally absorbed by the gastrointestinal tract. This finding is consistent with studies reporting from 1 to 10 percent oral absorption in several animal species (Friberg et al., 1986). Absorbed nickel is transported in the plasma bound to serum albumin and various organic ligands, amino acids, or polypeptides (Casarett and Doull, 1986).

\section{Tissue accumulation and clearance}

In humans, serum nickel levels reportedly peak 2.5 to 3 hours after ingestion of nickel sulfate. In individuals who accidentally drank water contaminated with nickel sulfate and nickel chloride, nickel mean serum half times were 60 hours. No human data were located regarding nickel levels in specific tissues or organs following ingestion of nickel compounds.

In animals, orally ingested nickel compounds distributed primarily to the kidneys, with significant nickel levels also found in the liver, heart, lung, fat, peripheral nervous tissues, and brain. Increased levels of nickel also were found in the fetuses of animals exposed orally to nickel compounds, suggesting that nickel crosses the placental barrier (DHHS, 1993b). 


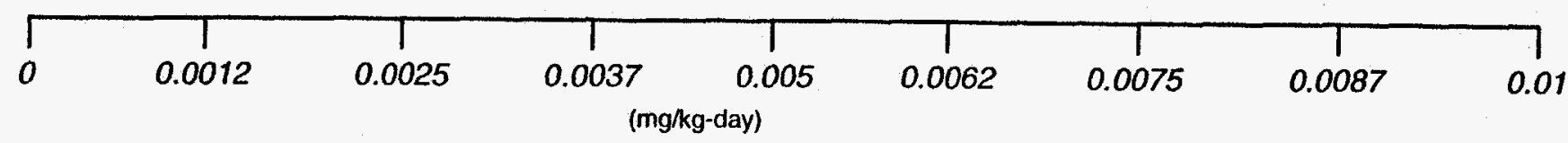

0
$\vdots$
$\square$

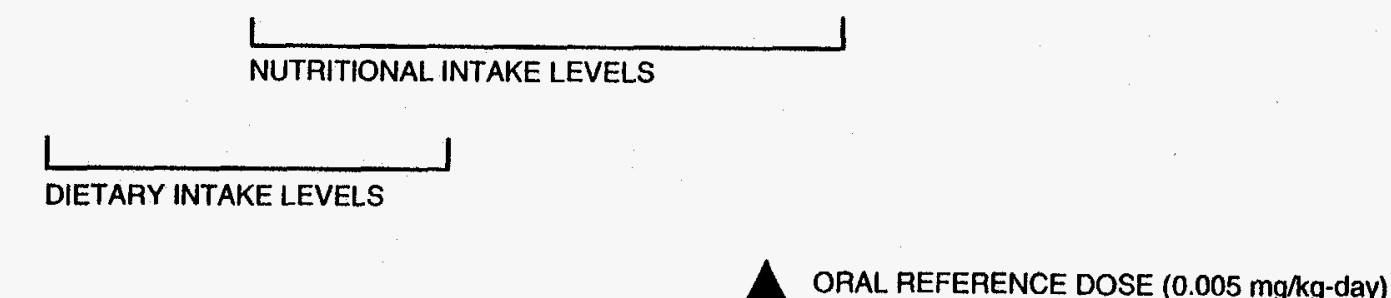

NO OBSERVED EFFECT LEVEL

$\cdots$

MILD TOXICITY - INCREASED COPPER EXCRETION

INCREASED URIC ACID SYNTHESIS

FIGURE 5.3

MOLYBDENUM TOXICITY RANGES 
In humans, limited absorption causes the majority of ingested nickel to be excreted in the feces. Nickel absorbed in the gastrointestinal tract is excreted in the urine. Excretion of a given dose of nickel is nearly complete in 4 or 5 days (Casarett and Doull, 1986), with approximately 26 percent of the dose excreted in the urine and the remainder eliminated in the feces (DHHS, 1993b).

\section{Environmental sources of nickel}

Exposure to nickel can occur through inhalation of ambient air and tobacco smoke and ingestion of water and food. Most intake occurs through the diet (DHHS, 1993b). In grains, fresh-weight nickel concentrations reportedly range from 0 to $6.45 \mu \mathrm{g} / \mathrm{g}$. In vegetables and fruits, levels range from 0 to $2.59 \mu \mathrm{g} / \mathrm{g}$ and in seafood from 0.3 to $107 \mu \mathrm{g} / \mathrm{g}$. Average daily dietary intake is approximately $165 \mu \mathrm{g}$ (Friberg et al., 1986). The drinking water daily intake averages $2 \mu \mathrm{g}$ (DHHS, 1993b).

Nickel is not commonly present at harmful levels in ground water. In a survey of United States ground water, 97 percent of all samples (total of 2053 samples) contained less than $20 \mu \mathrm{g} / \mathrm{L}$ of nickel and 80 percent had less than $10 \mu \mathrm{g} / \mathrm{L}$, although in areas near nickel mining operations, levels as high as $200 \mu \mathrm{g} / \mathrm{L}$ have been reported (Friberg et al., 1986).

\section{Toxicity of nickel}

Acute exposure to high levels of nickel in drinking water (1-day duration) reportedly produced symptoms of gastrointestinal distress including nausea, abdominal cramps, diarrhea, and vomiting. The estimated exposure dose of 7.1 to $35.7 \mathrm{mg} / \mathrm{kg}$ also produced transient hematological effects, muscular pain, transient increases in urine albumin, and neurological effects (giddiness and weariness). These health effects are summarized in Figure 5.4 as a function of dose.

The effects of chronic nickel ingestion in humans have not been well documented. In laboratory animals (dogs and rats), the primary effects of longterm dietary administration of nickel sulfate were decreases in body weight and changes in organ weights. Low hematocrit and polyuria were also reported for dogs (DHHS, 1993b).

A susceptible population may exhibit a different or enhanced response to nickel than will most persons exposed to the same level of nickel in the environment. Chemical exposure history, genetic make-up, developmental state, health, and nutritional status result in decreased function of the detoxification and excretory processes (mainly hepatic and renal) or the preexisting compromised function of target organs. For these reasons, it is expected the elderly with declining function and the youngest of the population with immature and developing organs will generally be more vulnerable to toxic substances than healthy adults. 


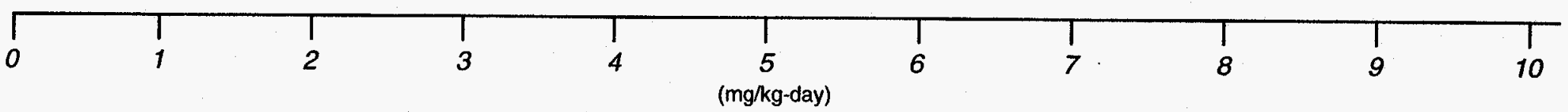

1 BACKGROUND INTAKE LEVEL FROM DRINKING WATER

1

AVERAGE DIETARY INTAKE LEVEL

$\triangle$ ORAL REFERENCE DOSE $=0.02 \mathrm{mg} / \mathrm{kg}$-day

ALLERGIC DERMATITIS IN SENSITIZED INDIVIDUALS

$\cdots \cdot$

MODERATE TOXICITY IN HUMANS

(TRANSIENT HEMATOLOGICAL EFFECTS

MUSCULAR PAIN, TRANSIENT KIDNEY

IMPAIRMENT, NEUROLOGICAL EFFECTS

GIDDINESS AND WEARINESS)

FIGURE 5.4

NICKEL TOXICITY RANGES 
Exposure to nickel may lead to sensitization. Available data indicate that oral exposure to relatively low levels of nickel may elicit allergic dermatitis in sensitized individuals (DHHS, 1993b). Epidemiologic studies indicate that blacks have a higher sensitivity than whites and that women of either racial group have higher reaction rates than men (DHHS, 1993b). The incidence of allergic reactions may be higher in women because they wear more metal jewelry than do men. The threshold for elicitation of the response has been suggested to be approximately $0.007 \mathrm{mg} / \mathrm{kg}$-day following oral challenge. Cross-sensitivity of nickel and other metals (e.g., cobalt) has also been reported (DHHS, 1993b).

For the rat, a NOAEL of 100 parts per million (ppm) of nickel in diet (5 mg/kg-day) was reported. The EPA chronic RfD was derived based on this NOAEL for human oral exposure to nickel. Considering the uncertainties with interspecies extrapolation and protection of sensitive populations, an oral RfD of $0.02 \mathrm{mg} / \mathrm{kg}$-day has been developed for nickel (EPA, 1994). This value represents a chronic daily ingestion dose which would not be expected to produce adverse health effects in humans.

\subsubsection{Sulfate}

\section{Absorption}

Sulfate absorption from the gastrointestinal tract is similar between humans and other animals. Generally, greater than 90 percent absorption has been reported for doses of sulfate below $150 \mathrm{mg} / \mathrm{kg}$, decreasing to 50 to 75 percent as the dose increases into the grams per kilogram range.

\section{Tissue accumulation and retention}

Ingestion of high levels of sulfate results in transient increases in both blood and urine concentrations. For sulfate doses of approximately $75 \mathrm{mg} / \mathrm{kg}$, approximately 50 percent of the dose is excreted over 72 hours. The urinary excretion mechanism is transport-limited and can therefore become saturated at high doses of sulfate. Excess sulfate is also excreted in feces in its inorganic form. To date, no data are available that indicate sulfate is accumulated, even with chronic ingestion of above-normal levels. However, extremely high chronic doses do not appear to have been examined in humans.

Sulfate is used in the biosynthesis of collagen, cartilage, and dentin and in the formation of sulfate esters of both endogenous compounds (such as lipids and steroids) and exogenous compounds (such as phenols). Sulfation is important in detoxication pathways because it increases the solubility of these compounds, which enhances their excretion in the urine. Exposure to high concentrations of compounds that are conjugated with sulfate and excreted can produce a transient decrease in sulfate concentrations in plasma. 


\section{Environmental sources of sulfate}

Drinking water in the western United States in 1978 showed a range of sulfate concentrations from 0 to $820 \mathrm{mg} / \mathrm{L}$, with a mean concentration of $99 \mathrm{mg} / \mathrm{L}$ of sulfates. The EPA estimates a normal sulfate intake range of 0.00023 to $0.0064 \mathrm{mg} / \mathrm{kg}$-day from air and up to $2.9 \mathrm{mg} / \mathrm{kg}$-day from drinking water in the concentration range found in supplies in the western United States. No estimates are available on intake of sulfates from food sources.

\section{Toxicity of sulfate}

As with nitrate toxicity, the acute and chronic effects of sulfate toxicity differ more in severity than in symptoms or mechanisms. Therefore, this discussion will combine acute and chronic toxicity. As mentioned above, there are no data to indicate a bioaccumulation of sulfate with chronic exposure. Sulfate salts of magnesium and sodium are used medicinally as cathartics. The presence of high concentrations of unabsorbed sulfate salts in the gut can pull large amounts of water into the gut, greatly increasing the normal volume of feces. This is the basis of the toxic effects as well.

Toxicity in humans is primarily manifested in diarrhea; the severity of the diarrhea is dose-dependent. Chronic ingestion of sulfate can result in persistent diarrhea, leading to ionic imbalances and dehydration similar to that seen with extremely high acute doses. In the case of drinking water contaminated with sulfate, the taste of the water may make it unpalatable and reduce consumption. However, this is not necessarily the case. In regions such as Saskatchewan with high sulfate concentrations in the drinking water, residents adapt to the taste and find the water palatable (EPA, 1992b). In cases where consumption is reduced, a lower water intake could compound the dehydration effects of the diarrhea. Extreme dehydration can lead to death. As with nitrate toxicity, infants seem to be the most susceptible population for sulfate-induced diarrhea. Also, there are data to indicate diabetic and elderly populations with compromised kidney function may be more sensitive than healthy adults to the effects of sulfates (EPA, 1992b).

In cattle, high sulfate intake has resulted in sulfhemoglobinemia, a condition similar to the methemoglobinemia induced by nitrate ingestion (EPA, 1992b). No reports of sulfhemoglobinemia have been reported following ingestion of sulfate by humans, although the condition has been reported in humans following inhalation of hydrogen sulfide.

As with nitrate, data on sulfate toxicity are based primarily on epidemiologic studies of human adults and infants who report to hospitals with symptoms of sulfate exposure. In most cases, exposure doses have been back-calculated from sampling their drinking water. Therefore, these data do not represent well-controlled studies where dosage ranges can be readily defined. 
Potential toxic effects from sulfate ingestion are summarized as a function of dose in Figure 5.5.

\subsubsection{Uranium}

Three radioactive isotopes occur naturally at UMTRA Project sites: uranium234, uranium-235, and uranium-238. More than 99 percent of natural uranium occurs in the form of uranium-238 (Cothern and Lappenbusch, 1983). Uranium238 undergoes radioactive decay by emitting alpha particles to form uranium234 , thorium-230, radium-226, radon-222, polonium-210, and other radioisotopes. The radioactive decay chain of uranium-238 and uranium-234 is summarized in Figure 5.6. As all uranium isotopes in nature are radioactive, the hazards of a high uranium intake come both from its chemical toxicity and potential radiological damage. This section focuses on the chemical toxicity of natural uranium. Carcinogenic potential associated with exposure to radioactive isotopes of natural uranium is discussed in Section 5.3.

\section{Absorption}

Absorption of uranium in the gastrointestinal tract depends on the solubility of the uranium compounds. The hexavalent uranium compounds, especially the uranyl salts, are water soluble, while tetravalent compounds generally are not (Weigel, 1983). Even with soluble compounds, only a small fraction is absorbed. Human gastrointestinal absorption rates of 0.76 to 7.8 percent have been determined (Wrenn et al., 1985).

\section{Tissue accumulation and clearance}

In humans exposed to background levels of uranium, the highest concentrations of uranium were found in the bones, muscles, lungs, liver, and kidneys (Fisenne et al., 1988). Uranium retention in bone consists of a short retention half-time of 20 days, followed by a long retention half-time of $\mathbf{5 0 0 0}$ days for the remainder (Tracy et al., 1992).

In body fluids, uranium tends to be converted into water-soluble hexavalent uranium (Berlin and Rudell, 1986). Approximately 60 percent of the uranium in plasma complexes with low-molecular-weight anions (e.g., bicarbonates, citrates), while the remaining 40 percent binds to the plasma protein transferrin (Stevens et al., 1980). Following oral exposure in humans, more than 90 percent of uranium is excreted in the feces and not absorbed in the gastrointestinal tract. Of the small percent that is absorbed (typically less than 5 percent), approximately 60 percent is excreted in the urine within 24 hours and 98 percent is excreted within 7 days, based on animal studies (Ballou et al., 1986; Leach et al., 1984; Sullivan et al., 1986). A small portion of the absorbed uranium is retained for a longer period. 


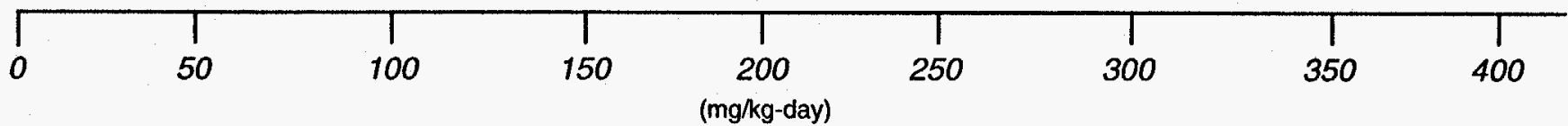

U

BACKGROUND INTAKE LEVELS

LO ÖB̈SERVED EFFECTS

…

MILD TOXICITY RANGING FROM LAXATIVE EFFECT (ADULTS) TO DIARRHEA IN INFANTS

SËEERE TOXICITY - PERSISTENT INFANT DIARRHEA LEADING TO DEHYDRATION $\cdots . . .-$ DEATH

FIGURE 5.5

SULFATE TOXICITY RANGES 


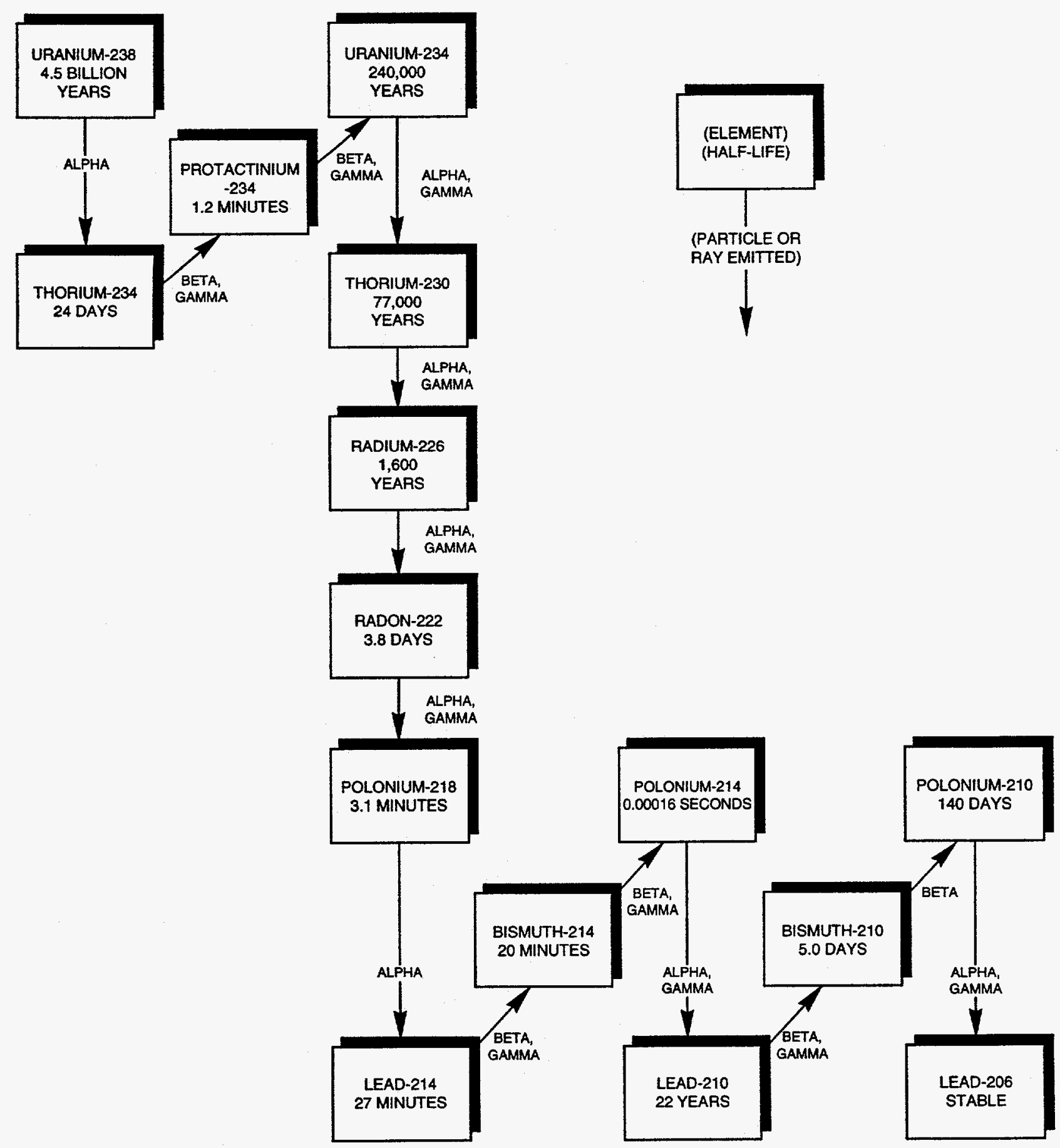

FIGURE 5.6

HALF-LIVES AND EMISSIONS FROM DECAY CHAIN OF URANIUM-238 


\section{Environmental sources of uranium}

Uranium is a ubiquitous element, present in the earth's crust at approximately 4 parts per million. Uranium concentrations in ground water and surface water averaged $1 \mathrm{pCi} / \mathrm{L}$ and $3 \mathrm{pCi} / \mathrm{L}$, respectively (NCRP, 1984). It is absorbed from the soil into plant tissues to an extent that depends on the plant species and the depth of its root system (Berlin and Rudell, 1986). Plant concentrations of uranium averaged $0.075 \mu \mathrm{g} / \mathrm{kg}$ of fresh plant material (Tracy et al., 1983).

The main dietary source of natural uranium for the general population is food products such as potatoes, bakery products, meat, and fresh fish, which may contain uranium concentrations between 10 and $100 \mu \mathrm{g} / \mathrm{kg}$ (Prister, 1969). The total dietary intake of uranium from the consumption of average foods is approximately $1 \mu \mathrm{g} / \mathrm{day}$, additionally approximately 20 to 50 percent of that total can come from drinking water. Cereals and vegetables, particularly root crops, are likely to contribute most to the daily intake of uranium (Berlin and Rudell, 1986).

\section{Toxicity of uranium}

Exposure of the general public to natural uranium is unlikely to pose an immediate lethal threat to humans. No human deaths have been reported that are definitely attributable to uranium ingestion; therefore, no lethal dose has been determined for humans. In laboratory animals, lethal doses of uranium $\left(L D_{50,23}\right.$ ) have been reported to be as low as $14 \mathrm{mg} / \mathrm{kg}$-day following 23-day oral exposures, depending on the solubility of the uranium compound tested (higher solubility compounds have greater toxicity), route of exposure, and animal species. High doses of uranium cause complete kidney and respiratory failure.

No chronic toxic effects have been reported in humans following oral exposure to uranium. Data available from populations occupationally exposed to high concentrations of uranium compounds through inhalation and information from studies in experimental animals indicate that the critical organ for chronic uranium toxicity is the proximal tubule of the kidney (Friberg et al., 1986). In humans, chemical injury reveals itself by increased catalase excretion in urine and proteinuria. Dose-response data are limited for the toxic effect of uranium on the human kidney.

The lowest dose of uranyl nitrate to cause moderate renal damage was given to rabbits in diet at $2.8 \mathrm{mg} / \mathrm{kg}$-day (Maynard and Hodge, 1949). The health effects for uranium are summarized in Figure 5.7 as a function of dose. 


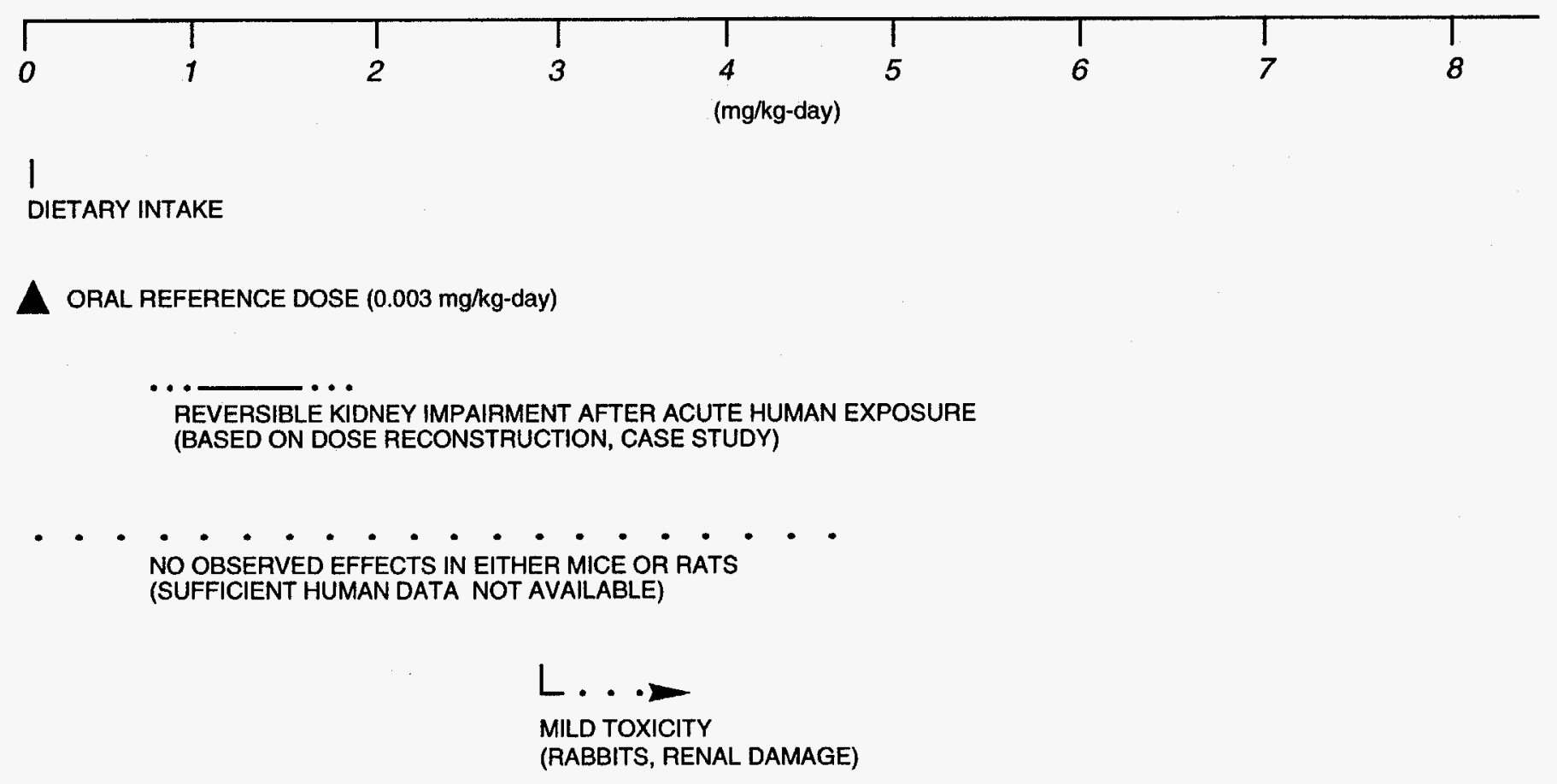

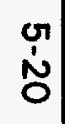

REVERSIBLE KIDNEY IMPAIRMENT AFTER ACUTE HUMAN EXPOSURE (BASED ON DOSE RECONSTRUCTION, CASE STUDY)

(RABBITS, RENAL DAMAGE)

FIGURE 5.7

URANIUM TOXICITY RANGES

MAC: SITF/RVT/RRA/l IRN-FFN 


\subsubsection{Vanadium}

\section{Absorption}

Absorption of vanadium from the gastrointestinal tract is low. The ICRP (1960) estimate for the absorption of soluble vanadium compounds is 2 percent, but the World Health Organization (WHO) states that absorption of even very soluble forms of vanadium is less than 1 percent from the gastrointestinal tract (WHO, 1988). Limited human data (from three individuals) have suggested that as much as 10 percent of a repeated oral dose may be absorbed (Proescher et al., 1917; Tipton and Cook, 1963). Soluble vanadium compounds that are inhaled and deposited are more readily absorbed (about 25 percent) (WHO, 1988). Although soluble forms of vanadium may be absorbed, absorption through the skin is probably minimal (EPA, 1977; WHO, 1988).

\section{Tissue accumulation and clearance}

Vanadium is found in all body tissues in concentrations ranging from $0.08 \mu \mathrm{g}$ per gram wet weight in spleen tissue to $0.14 \mu \mathrm{g}$ per gram in brain and heart tissue and $0.33 \mu \mathrm{g}$ per gram in aorta tissue (Yakawa and Suzuki-Yasumoto, 1980). Concentrations of vanadium in human blood serum are reported to be 0.016 to 0.939 nanogram $(\mathrm{ng}) / \mathrm{mL}$. In hair, concentrations of vanadium ranging from 20 to $60 \mathrm{ng}$ per gram have been reported by different authors, with higher values found in manic-depressive patients than in normal control groups $(57$ versus $29 \mathrm{ng}$ per gram).

The distribution of vanadium in humans following oral exposure may be extrapolated from animal studies. In acute-duration exposures, vanadium is rapidly distributed, primarily in the bones. After intermediate-duration exposure, vanadium concentrations reaching the tissues are low, with the kidneys, bones, liver, and lungs initially showing the highest levels.

Vanadium is an element and is not metabolized. However, in the body, there is an interconversion of two oxidation states of vanadium: vanadyl and vanadate. Vanadium can reversibly bind to the protein transferrin in the blood and then be taken up into erythrocytes. There is a slower uptake of vanadyl into erythrocytes compared to the vanadate form, possibly due to the time required for the vanadyl form to be oxidized to vanadate. Initially, vanadyl leaves the blood more rapidly than vanadate, possibly because of the slower vanadyl uptake into cells (Harris et al., 1984). Five hours after administration, blood clearance is essentially identical for the two forms. Vanadate is the dominant species of vanadium present in ground water at the Riverton site.

Because vanadium is poorly absorbed in the gastrointestinal tract, a large percentage of vanadium in rats is excreted unabsorbed in the feces following oral exposure. In rats, the principal route of excretion of the small absorbed portion of vanadium is through the kidneys. The mean urinary output in a 24-hour period is reported to be $10 \mu \mathrm{g}$. 


\section{Environmental sources of vanadium}

Elemental vanadium does not occur in nature, but its compounds exist in more than $\mathbf{5 0}$ different mineral ores and in association with fossil fuels. The single largest release of vanadium to the atmosphere occurs through the combustion of fossil fuels, particularly residual fuel oils. The largest amount of vanadium released to soil and water occurs through the natural weathering of geological formations (Byerrum et al., 1974; Van Zinderen Bakker and Jaworski, 1980).

Food constitutes the major source of exposure to vanadium for the general population (Lagerkvist et al., 1986). For the general population as a whole, dietary intake is estimated to be 6 to $18 \mu \mathrm{g} /$ day (Pennington and Jones, 1987), although other estimates from older studies utilizing different and possibly less sensitive analytical methods have been as high as $2 \mathrm{mg} /$ day (Schroeder et al., 1963).

Drinking water is not considered an important source of vanadium exposure for the general population. 92 percent of water samples taken across the United States show values below $10 \mu \mathrm{g} / \mathrm{L}$. Typical values appear to be around $1 \mu \mathrm{g} / \mathrm{L}$ (Lagerkvist et al., 1986). The estimated daily intake of vanadium by the inhalation route is $1 \mu \mathrm{g}$ (Byrne and Kosta, 1978).

Although vanadium is considered an essential element for chickens and rats, there is no certainty about human dietary requirements. For animals, the daily requirement is about 10 to $25 \mu \mathrm{g} /$ day (Pennington and Jones, 1987).

\section{Toxicity of vanadium}

The major adverse health effect to humans from vanadium is seen in workers exposed to large amounts of vanadium pentoxide dusts. The probable oral lethal dose of vanadium pentoxide for humans is between 5 and $50 \mathrm{mg} / \mathrm{kg}$ (Gosselin et al., 1976).

Systemic effects of vanadium exposure have been observed in the liver, kidneys, nervous and cardiovascular systems, and blood-forming organs. Metabolic effects include interference with the biosynthesis of cystine and cholesterol, depression and stimulation of phospholipid synthesis and, at higher concentrations, inhibition of serotonin oxidation. Other effects of vanadium on mammalian metabolism include depression of phospholipid synthesis (Snyder and Cornatzer, 1958), reduction of coenzyme $Q$ levels in mitochondria (Aiyar and Sreenivasan, 1961), and stimulation of monoamine oxidase, which oxidizes serotonin (Perry et al., 1955).

Vanadium salts were given to patients in several studies to reduce cholesterol levels (Curran et al., 1959; Somerville and Davies, 1962; Dimond et al., 1963; Schroeder et al., 1963). The doses of vanadium in these studies varied from $7 \mathrm{mg} /$ day to $30 \mathrm{mg} / \mathrm{day}$. Transient decreases in serum cholesterol levels were 
observed in some patients, as were loosened stool and cramps. Green tongue, a hallmark of vanadium exposure, was observed in all patients.

A relationship between the concentration of vanadium in drinking water and the incidence of dental caries in children is reported by Tank and Storvick (1960). Dental caries incidence in children aged 7 to 11 years was reduced three times (compared to controls) by applying ammonium vanadate in glycerol to the teeth (Belehova, 1969). This relationship was not found in other studies (Hadjimarkos, 1966; 1968).

It has been suggested that raised tissue levels of vanadium are important in the etiology of manic-depressive illness. Improvement after treatment with ascorbic acid or reduced vanadium intake was seen both in manic and depressed patients.

Although animal studies have reported impaired conditioned reflexes following doses of vanadium from $0.05 \mathrm{mg} / \mathrm{kg}$-day (after 6 months of exposure) to $0.5 \mathrm{mg} / \mathrm{kg}$-day (after 21 days of exposure), effects on the nervous system have not been observed following repeated oral administration of vanadium in humans. Workers exposed by inhalation to fairly high concentrations of vanadium compounds have reported nonspecific symptoms, including headache, weakness, vomiting, nausea, and ringing of the ears (WHO, 1988).

Available data on vanadium toxicity are insufficient to evaluate its effects on cholesterol levels, iron metabolism, blood-cell production, and mutagenesis. However, due to poor absorption from the gut, the metal is not considered very toxic following oral administration (WHO, 1988).

The toxicity of vanadium is summarized in Figure 5.8 .

\subsection{CONTAMINANT RISK FACTORS}

The EPA Office of Research and Development has calculated acceptable intake values, or reference doses (RfD), for long-term (chronic) exposure to noncarcinogens. These values are estimates of route-specific exposure levels that would not be expected to cause adverse effects when exposure occurs for a significant portion of the lifetime. The RfDs include safety factors to account for uncertainties associated with limitations of the toxicological data base, including extrapolating results from animal studies to humans and accounting for variability in response from sensitive individuals. These values are updated quarterly and are published in the Health Effects Assessment Summary Tables (HEAST) and also are provided through the EPA's IRIS data base. Table 5.1 summarizes the most recent oral RfDs for the noncarcinogenic contaminants of concern.

The EPA currently classifies all radionuclides as Group A, or known human carcinogens, based on their property of emitting ionizing radiation and on the evidence provided by epidemiological studies of radiation-induced cancer in 


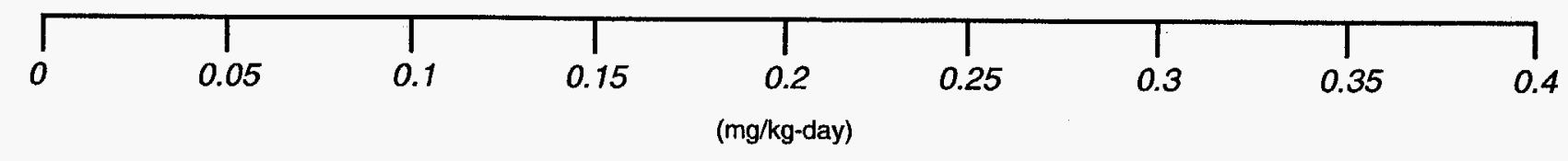

| DIETARY INTAKE

A ORAL REFERENCE DOSE - DRINKING WATER $(0.007 \mathrm{mg} / \mathrm{kg}$-day $)$

TRANSIENT CHOLESTEROL DROP, CRAMPS, GREEN TONGUE

ESTIMATED LETHAL DOSE (5 - $50 \mathrm{mg} / \mathrm{kg}$-day)

FIGURE 5.8

VANADIUM TOXICITY RANGES 


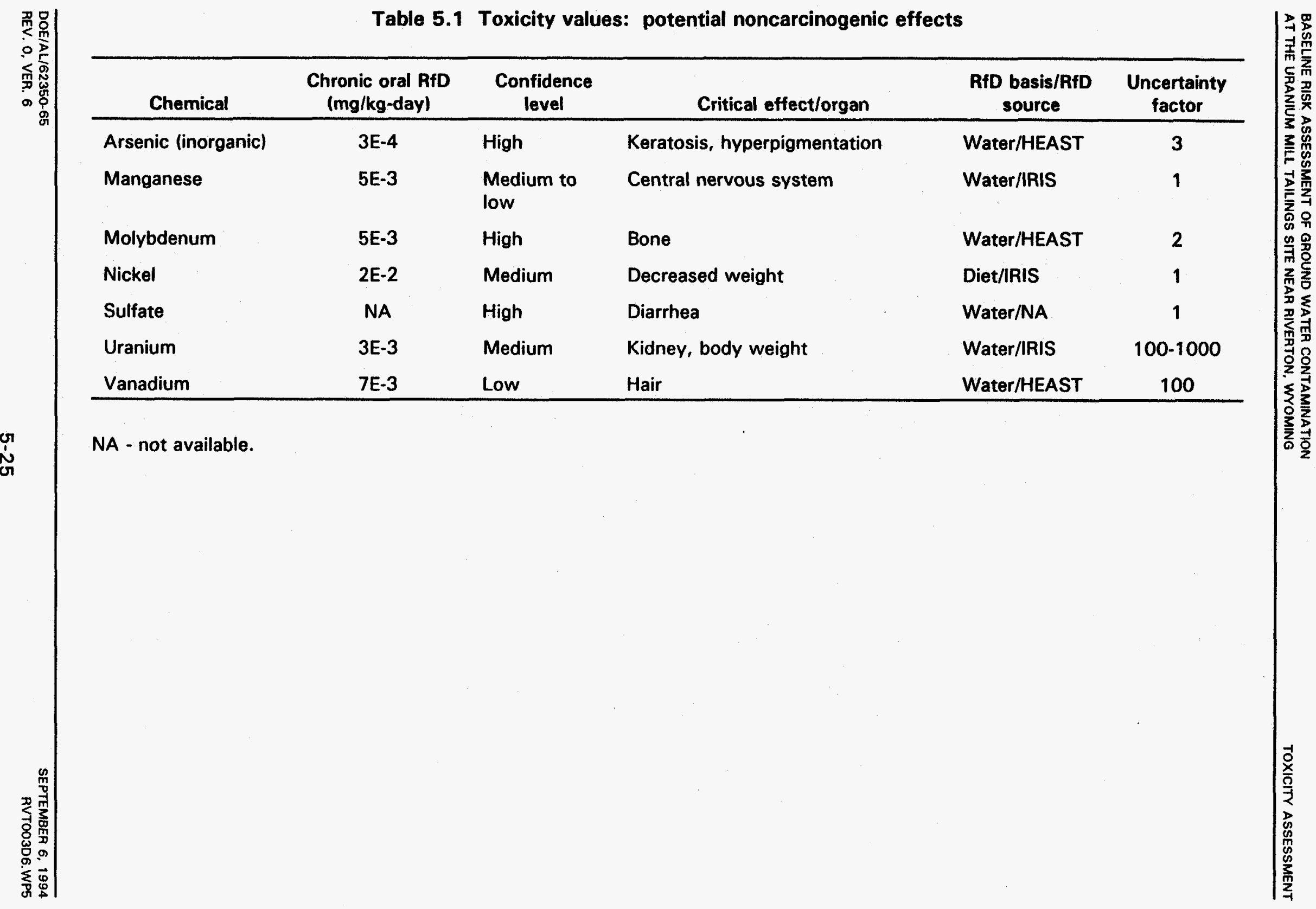


humans. Risk factors are published in HEAST and IRIS for correlating intake of carcinogens over a lifetime with the increased excess cancer risk from that exposure. Table $\mathbf{5 . 2}$ gives the most recent cancer slope factors (SF) for arsenic and the uranium-234/-238 radioactive decay series.

\subsection{CONTAMINANT INTERACTIONS}

Although some information is available on potential interactions between contaminants found at UMTRA Project sites, potential interactions can generally be evaluated only qualitatively. In addition to physiological variables among individuals that can affect toxicity, uncertainties in interactions also result from 1) differences in the relative exposure concentrations of the different contaminants compared to the experiment concentrations, and 2) additional ground water constituents that may be present in sufficient quantities to modify predicted toxicities even when they are not considered contaminants of concern for human health. Therefore, the interactions described below should be recognized as factors that can influence predicted toxicity, although the precise nature and magnitude of that influence cannot be determined.

Molybdenum can produce a functional copper deficiency, but only in the presence of sulfate. Laboratory animal studies show molybdenum toxicity to be more pronounced when dietary copper intake is low (EPA, 1994). In ruminants, which are very susceptible to imbalances between these elements, copper prevents the accumulation of molybdenum in the liver and may antagonize absorption of molybdenum into the bloodstream. It has also been suggested that sulfur can displace molybdate in the body (Casarett and Doull, 1991). Both copper and sulfates can protect against molybdenum toxicity in ruminants, and molybdenum and sulfur can block copper toxicity.

Interactions between several similar metals can alter the predicted absorption, distribution in the body, metabolism, toxicity, or clearance of a metal of interest. For example, manganese absorption can be considerably increased under conditions of low calcium or iron (DHHS, 1992a).

Administered in combination to pregnant mice, vanadium and manganese caused alterations in behavioral development compared to either metal administered alone (DHHS, 1992a; 1992b). Oral administration of vanadium may interfere with the intestinal absorption of copper.

Nickel may interact with other heavy metals such as iron, manganese, zinc, and cadmium (DHHS, 1993b). Nickel toxicity can be mitigated by high levels of zinc. Under iron deficiency status, nickel may facilitate the passive diffusion of iron by stabilizing the transport ligand, increasing its gastrointestinal absorption, but only when the iron is present in the form of ferric ion (DHHS, 1993b). An interrelationship exists between nickel and cobalt sensitization in individuals exposed to the two metals (DHHS, 1992c; 1993b). 


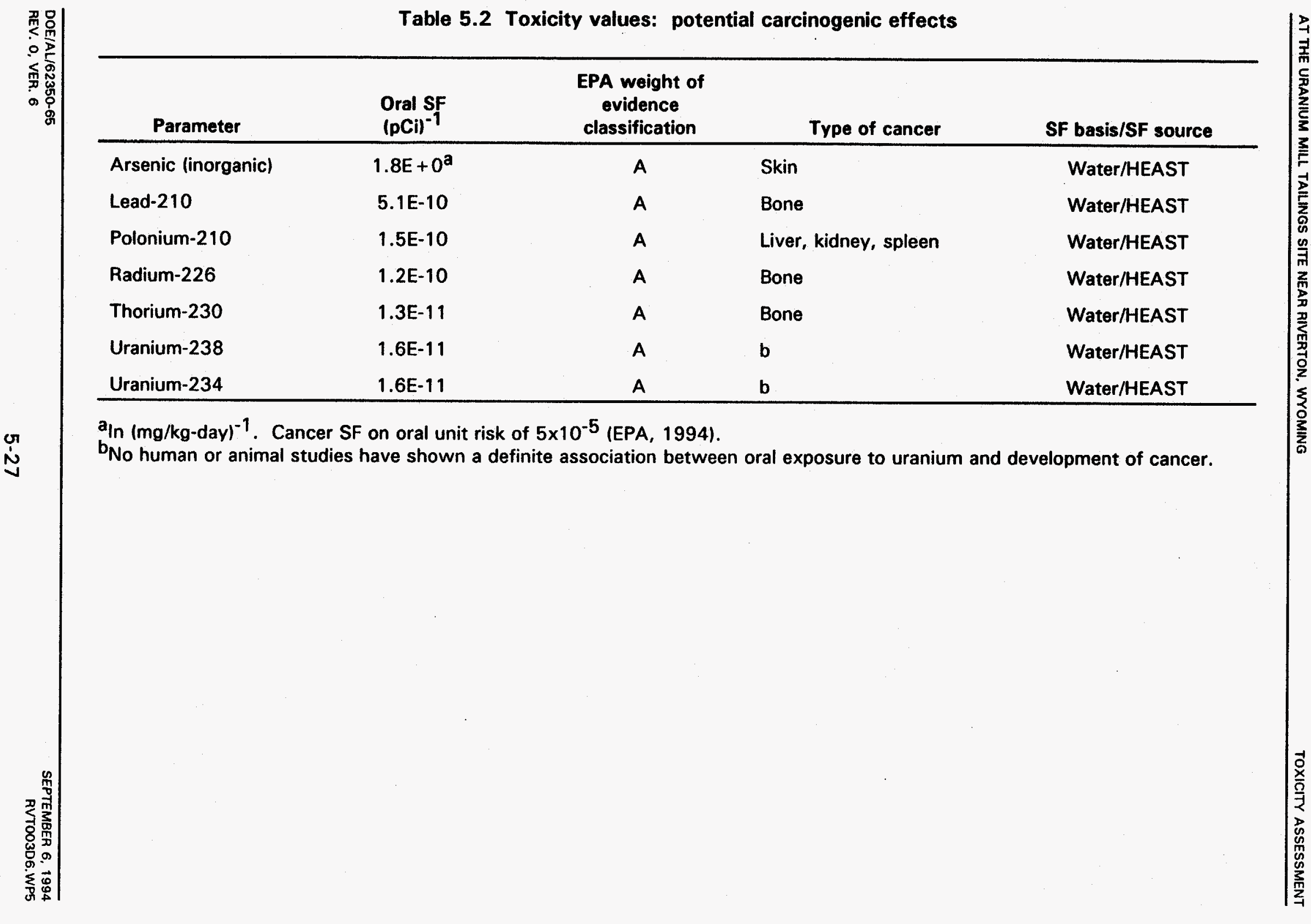


No information on uranium interaction with other metals was found in preparation for this risk assessment. However, the common target organ suggests interaction with arsenic and nickel in the production of kidney toxicity.

The carcinogenic effects of the radionuclides probably combine at least additively. Arsenic carcinogenicity is a distinct mechanism and may not necessarily be truly additive with radionuclide cancer risks. 


\subsection{RISK EVALUATION}

To evaluate human health risks to an individual or population, the results of the exposure assessment are combined with the results of the toxicity assessment. As discussed in Section 5.0, potential adverse health effects are a function of how much of a contaminant an individual takes into his or her body. Because many of the contaminants associated with the mill tailings are essential nutrients, they are beneficial to health at lower levels. At higher levels, these same elements can cause adverse health effects or, at very high levels, death. This section correlates the expected contaminant intake (if ground water within the plume were used as drinking water) to the potential health effects of these levels of exposure.

\subsection{POTENTIAL NONCARCINOGENIC HEALTH EFFECTS}

\section{Surficial aquifer}

The results from the exposure assessment for either the highest intake-to-bodyweight ratios (or highest doses) or the toxicologically most sensitive group are used to evaluate the potential health effects of noncarcinogens. For arsenic, manganese, molybdenum, nickel, uranium, and vanadium, the highest intakeper-body-weight group is children 1 to 10 years old. The 0 - to 1 -year-old age group was used for sulfate because this age group is more susceptible to its toxicity. Figures 6.1 through 6.7 show the intake distributions for these age groups, with toxicity information for each contaminant of potential concern.

The exposures estimated for arsenic are comparable to dietary intake levels (Figure 6.1). Noncarcinogenic health effects are not associated with these intakes; the expected value is the acceptable intake level (RfD of $0.0003 \mathrm{mg} / \mathrm{kg}$-day). The potential carcinogenicity of arsenic is described in Section 6.2.

Potential health effects are associated with almost the entire exposure distributions for manganese, molybdenum, and sulfate. Manganese exposures are in the range reported to cause neurological effects that include muscle rigidity and mental disturbances; in the upper 10th percentile of the exposure distribution, effects include a Parkinson-like syndrome. The entire distribution is above the EPA acceptable intake level (RfD of $0.005 \mathrm{mg} / \mathrm{kg}$-day), with the expected value occurring at greater than 30 times the RfD (Figure 6.2).

Nearly all the exposure distribution for molybdenum is associated with increased copper excretion. At the upper range of the distribution, gout-like disease may occur in humans (Figure 6.3). The expected value is about 6 times the acceptable intake level recommended by EPA (RfD of $0.005 \mathrm{mg} / \mathrm{kg}$-day).

The sulfate exposure distribution is well above the range shown to cause severe diarrhea and dehydration in infants (Figure 6.4). However, these high sulfate concentrations probably would affect the taste of the water, thereby reducing 


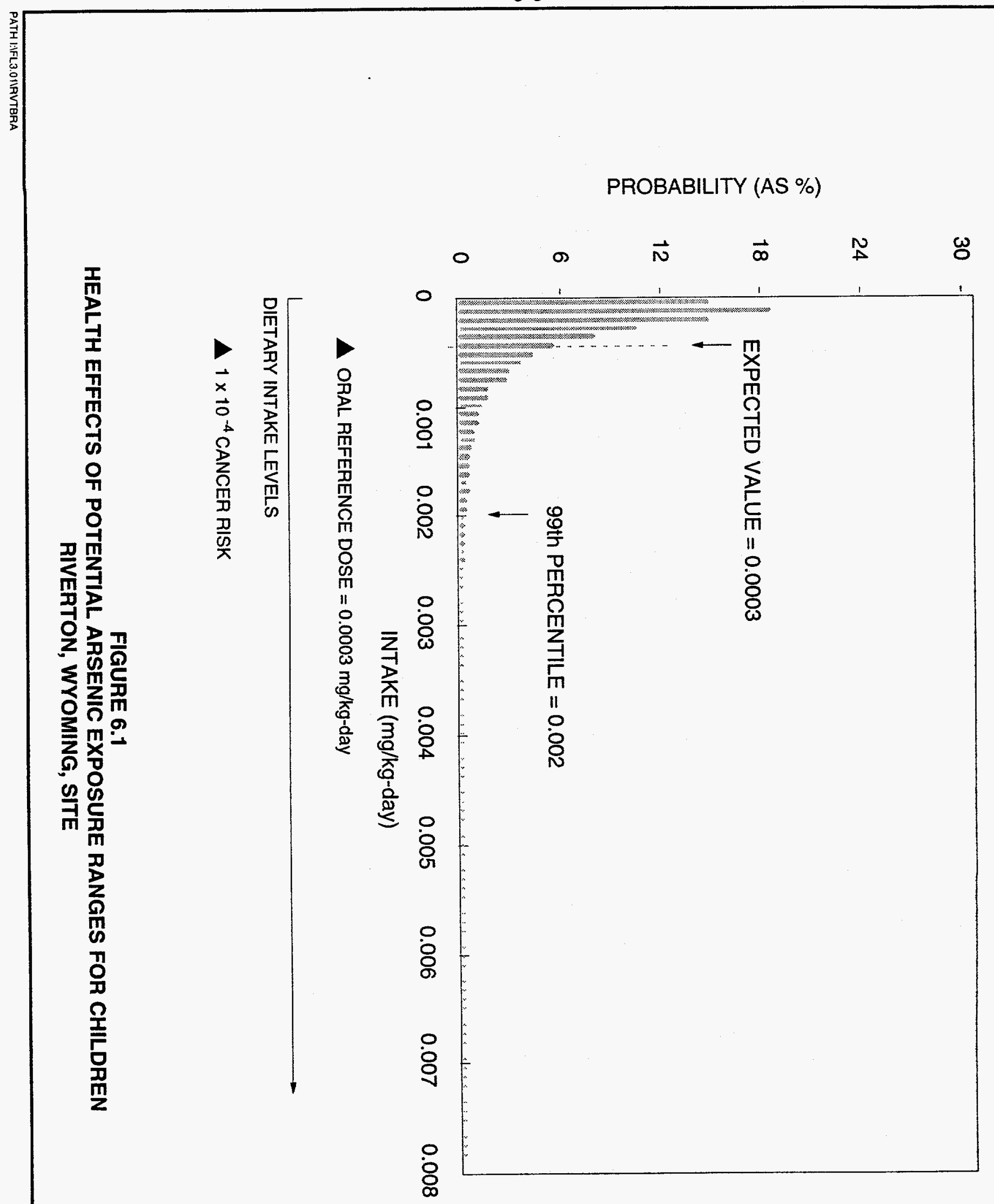




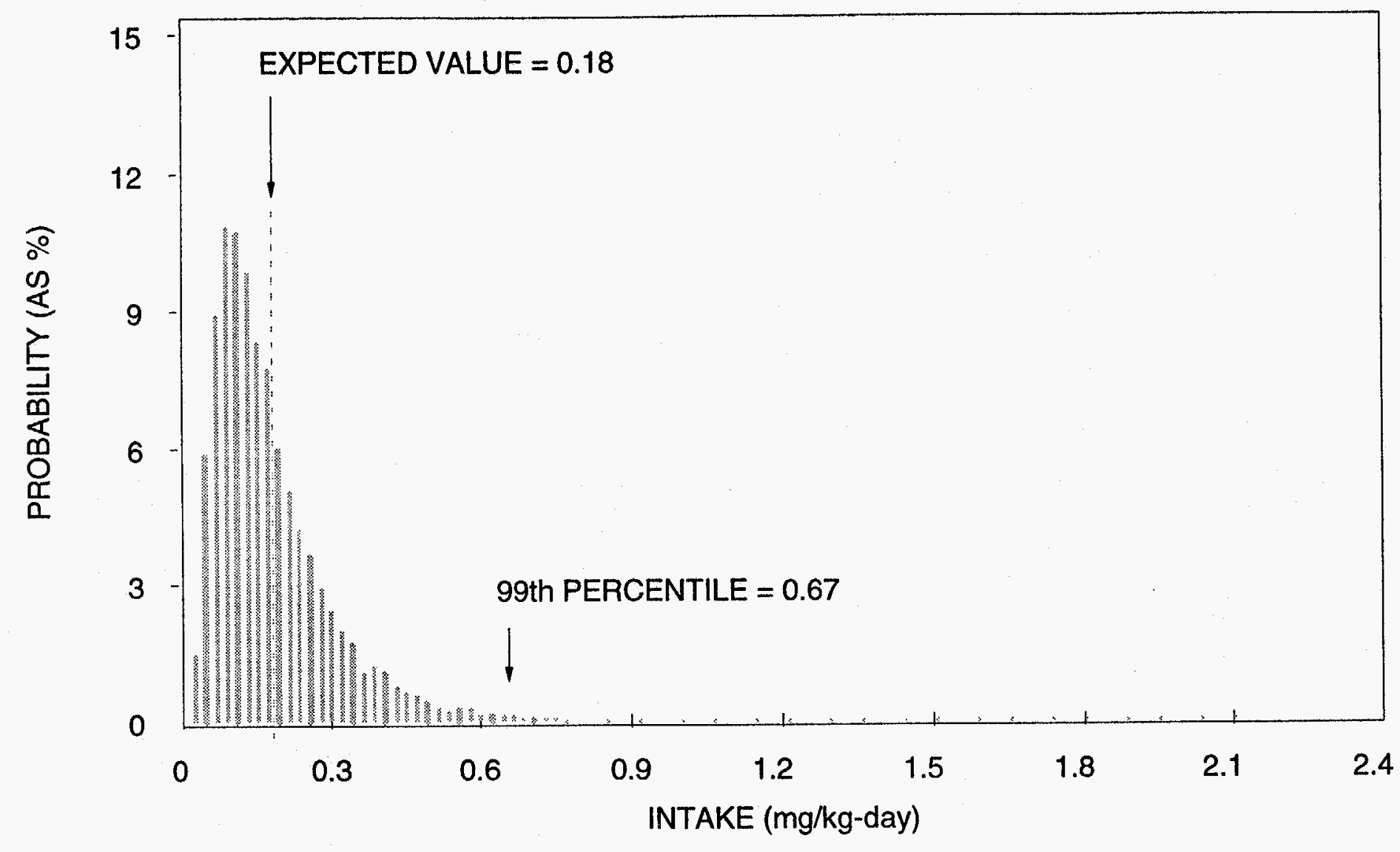

$\triangle$ ORAL REFERENCE DOSE $=0.005 \mathrm{mg} / \mathrm{kg}$-day

$\sqcup$ NUTRITIONAL INTAKE LEVELS

V BACKGROUND INTAKE FROM DRINKING WATER

EARLY NEUROLOGICAL SYMPTOMS

PARKINSON-LIKE NEUROLOGIC EFFECTS

FIGURE 6.2

HEALTH EFFECTS OF POTENTIAL MANGANESE EXPOSURE RANGES FOR CHILDREN RIVERTON, WYOMING, SITE 


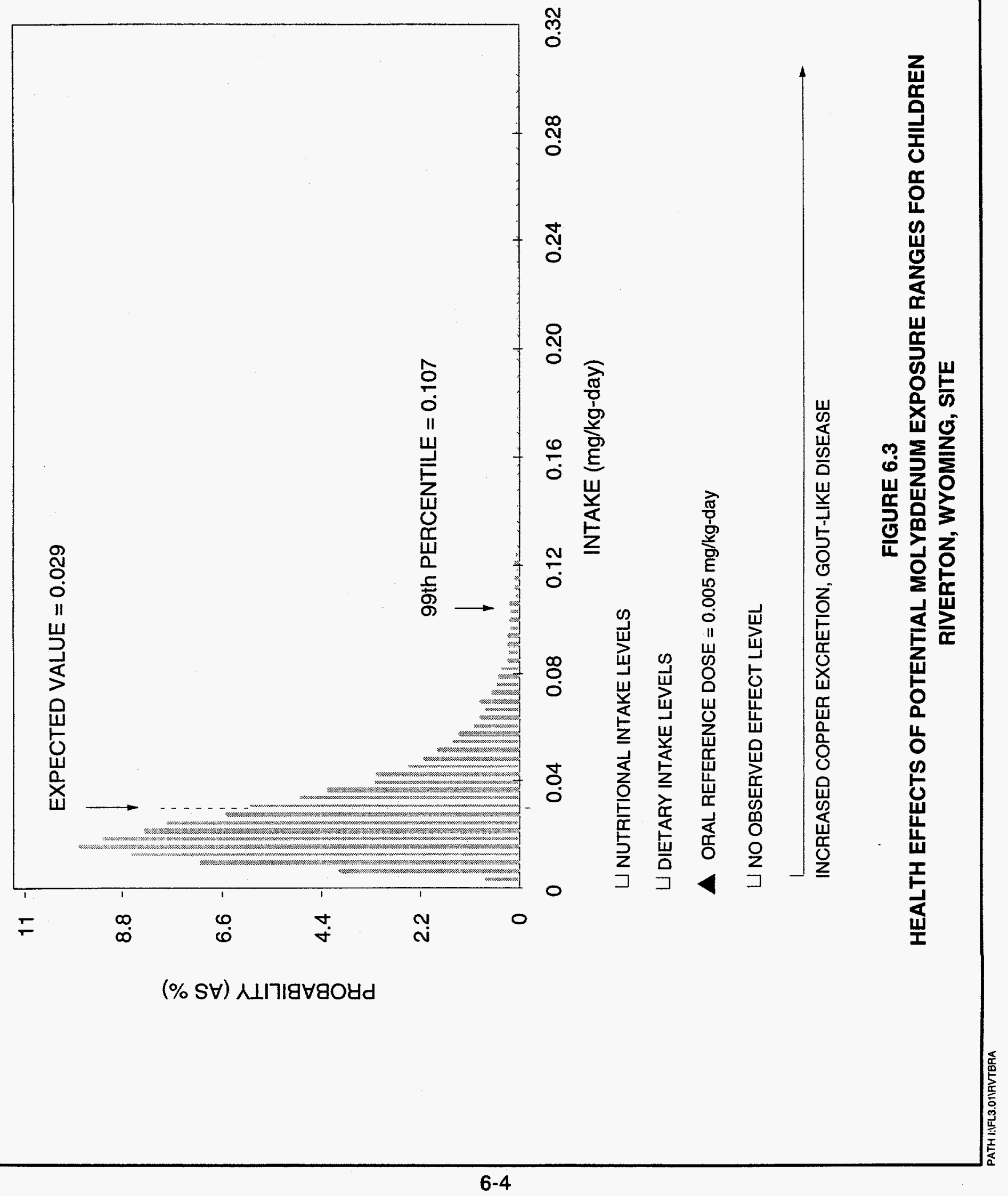




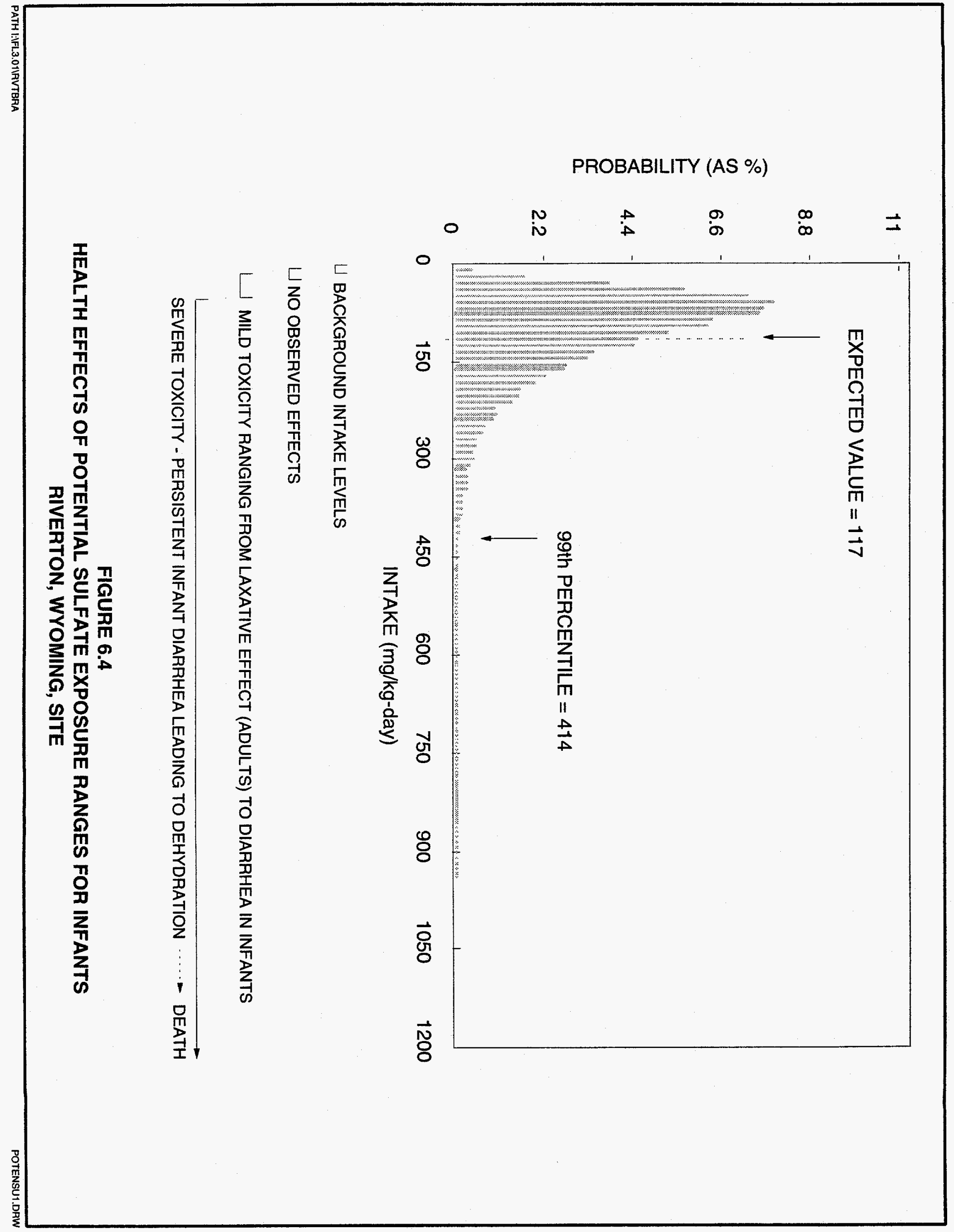




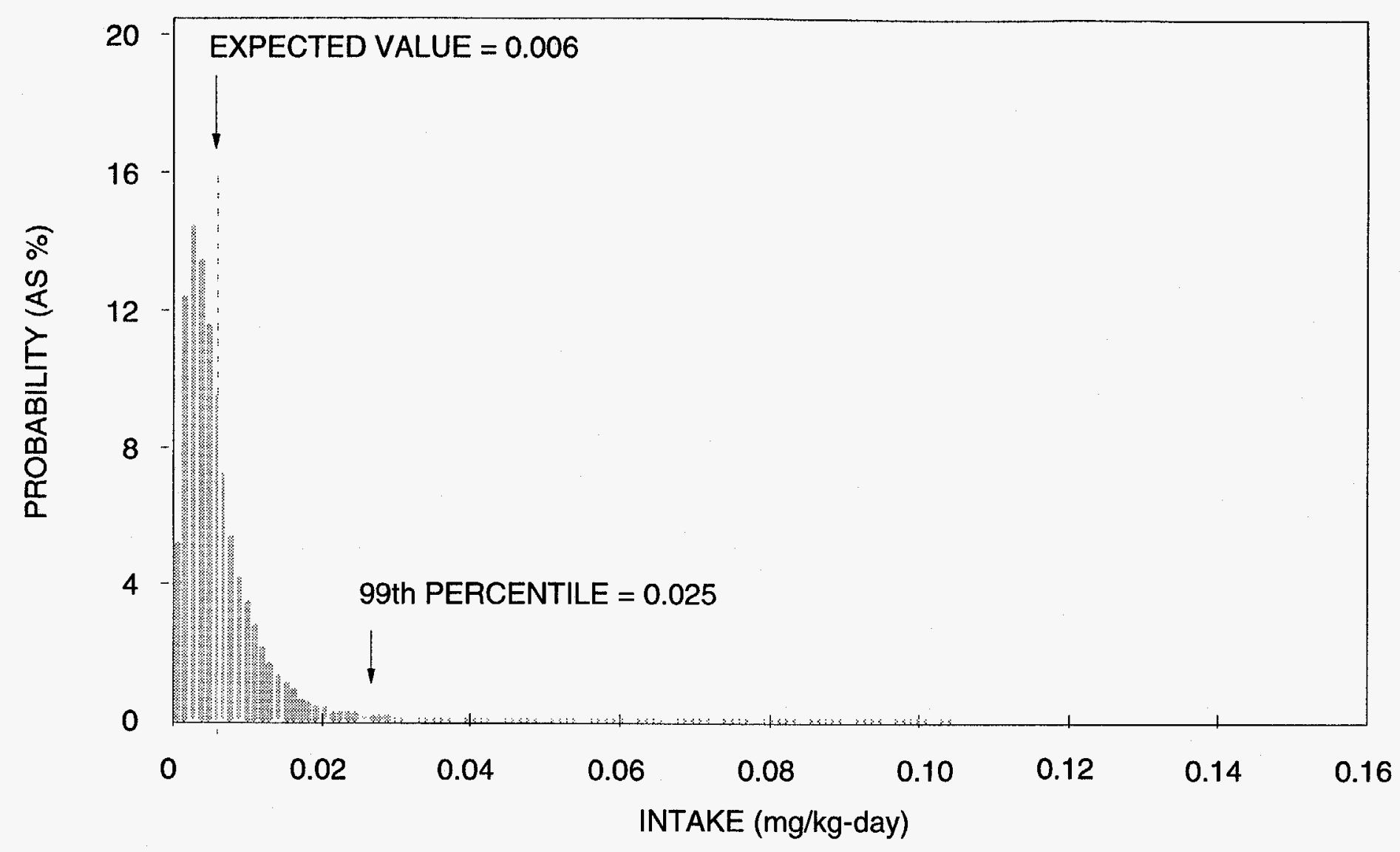

$\triangle$ ORAL ReFERENCE DOSE $=0.02 \mathrm{mg} / \mathrm{kg}$-day

$\sqcup$ DIETARY INTAKE LEVELS

FIGURE 6.5

HEALTH EFFECTS OF POTENTIAL NICKEL EXPOSURE RANGES FOR CHILDREN

RIVERTON, WYOMING, SITE 


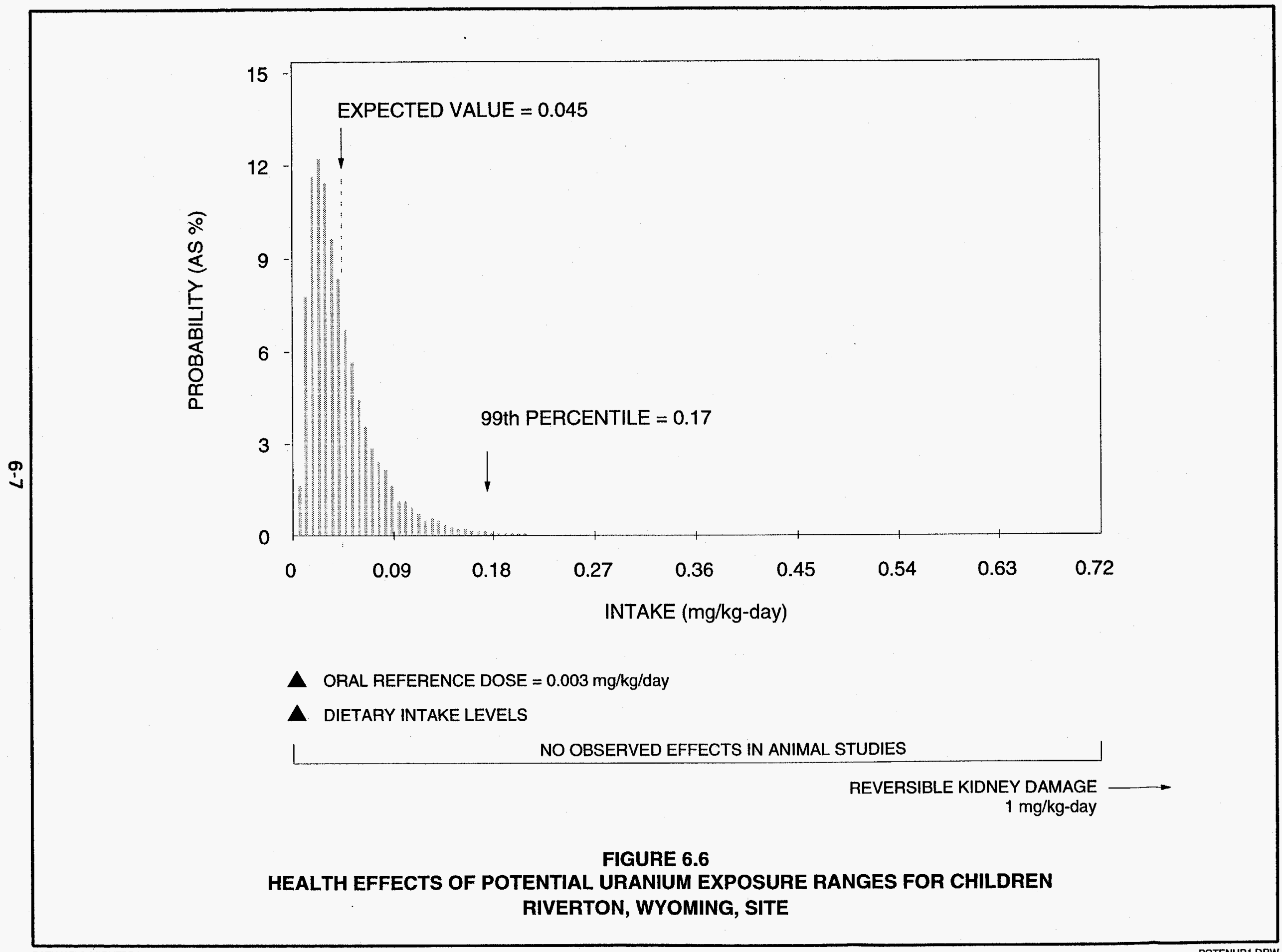




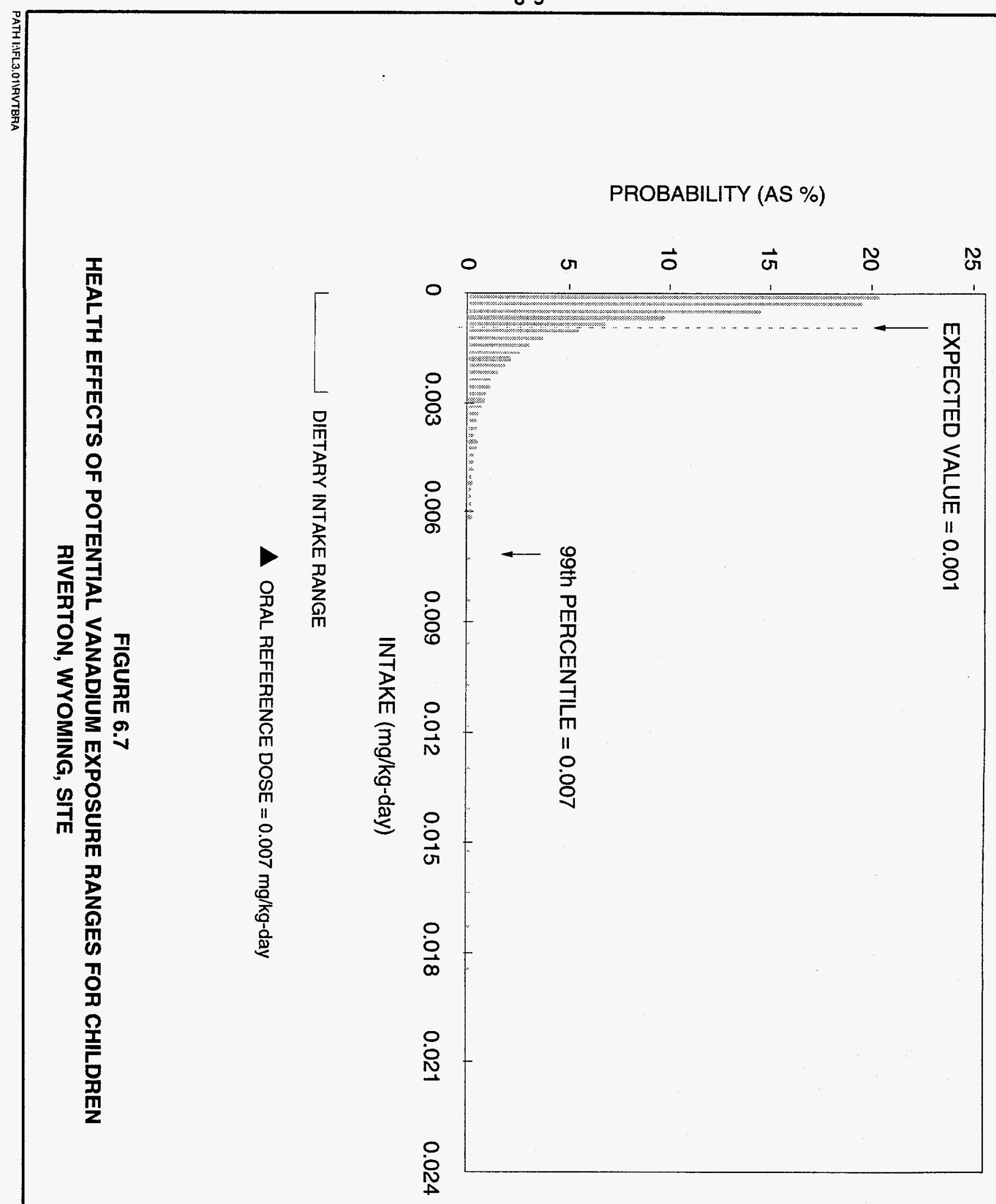


exposure potential. This reduced water intake could in turn exacerbate dehydration.

The exposure distribution for nickel is almost completely below the acceptable intake level (RfD of $0.02 \mathrm{mg} / \mathrm{kg}$-day), as shown in Figure 6.5 .

The entire exposure distribution for uranium falls within the no-observed-effect level and is less than one-tenth the level of any observed health effects in human or animal studies (Figure 6.6). However, 99 percent of the exposure distribution falls above the EPA acceptable intake level (RfD of $0.003 \mathrm{mg} / \mathrm{kg}$-day). This apparent discrepancy occurs largely because the toxicological data base is incomplete and the EPA has considered this uncertainty in determining its acceptable intake level. Uranium has not been demonstrated to serve a beneficial purpose in biological systems; therefore, unlike nutrient metals, a toxicity threshold is difficult to define. Though these low intake levels are not associated with adverse effects in humans or test animals, it is significant that most of the exposure distribution falls above this RfD criterion because of the low level of confidence in the toxicological data.

For vanadium, 99 percent of the exposure distribution is below the acceptable intake level; most of the distribution occurs within dietary ranges (Figure 6.7). If the potential ground water exposure is added to dietary intake, the combined dose is still below acceptable values.

Based on the assumptions of this risk assessment, the levels of arsenic, uranium, and vanadium detected in the shallow well southeast of the site are not associated with adverse health effects if ground water were used for irrigation and watering livestock.

\section{Semiconfined aquifer}

Levels of manganese, molybdenum, sulfate, and uranium are also elevated in the semiconfined aquifer. Chronically ingested at these levels, manganese would cause mild neurologic effects; molybdenum would cause increased copper excretion, potentially leading to gout; and sulfate could cause severe diarrhea. Uranium is associated with carcinogenic effects at these levels.

The exposure distributions in Figures 6.1 through 6.7 are based only on the ground water ingestion pathway for residential drinking water. In Section 4.2, the following additional exposure pathways were screened and found to be negligible compared to the drinking water ingestion pathway: dermal absorption; ingestion of ground water-irrigated produce; ingestion of meat from ground water-fed livestock; and ingestion of milk from ground water-fed livestock. To verify that these additional pathways would not contribute significant risks, the results of the screening calculations for each of the contaminants of potential concern were used to adjust the calculated risks for ground water ingestion by an amount appropriate to the incremental risks associated with those additional exposure pathways. No non-cancer risks for 
cancer risks) were significantly increased by consideration of the additional exposure pathways; therefore, the drinking water ingestion pathway is the dominant ground water exposure pathway, as indicated by the screening calculations in Section 4.2.

\subsection{POTENTIAL CARCINOGENIC HEALTH EFFECTS}

All uranium isotopes are radioactive and, as such, are considered potential carcinogens. Table 6.1 shows the uranium intake from the most contaminated well in the unconsolidated unit and the potential lifetime carcinogenic risk associated with exposure to this drinking water. This estimate is based on the cancer SF developed by the EPA; however, natural uranium has not been demonstrated to cause cancer in humans or animals following ingestion.

Table 6.1 Carcinogenic risk for ground water consumption pathway at Riverton, Wyoming, site

\begin{tabular}{lcccc}
\hline \multicolumn{1}{c}{ Radionuclides } & $\begin{array}{c}\text { Exposure point } \\
\text { concentration } \\
\text { (pCi/L) }\end{array}$ & $\begin{array}{c}\text { Intake } \\
\text { (pCi/lifetime) }\end{array}$ & $\begin{array}{c}\text { Ingestion } \\
\text { cancer } \text { SF } \\
\text { (pCi) }\end{array}$ & $\begin{array}{c}\text { Excess lifetime } \\
\text { cancer risk }\end{array}$ \\
\hline Lead-210 & 4.0 & $9 \mathrm{E}+4$ & $5.1 \mathrm{E}-10$ & $4 \mathrm{E}-5$ \\
Polonium-210 & 2.4 & $5.0 \mathrm{E}+4$ & $1.5 \mathrm{E}-10$ & $8 \mathrm{E}-6$ \\
Thorium-230 & 6.8 & $1.4 \mathrm{E}+5$ & $1.3 \mathrm{E}-11$ & $2 \mathrm{E}-6$ \\
Uranium-234/-238 & 810 & $1.7 \mathrm{E}+7$ & $1.6 \mathrm{E}-11$ & $3 \mathrm{E}-4$ \\
\hline
\end{tabular}

Intake assuming 2 L/day, 365 days per year, for 30 years.

The estimated lifetime excess cancer risk from ingesting uranium in ground water $\left(3 \times 10^{-4}\right)$ exceeds the National Contingency Plan guidance for maximum increased lifetime cancer risk of $1 \times 10^{-4}$. This calculation is based on a cumulative, 30-year exposure. As discussed previously, this exposure duration is probably appropriate, but uranium concentrations in ground water are expected to decline because the tailings have been removed. Therefore, this calculation probably overestimates risk.

Uranium decays to other radioactive elements that are also considered carcinogenic. Table 6.1 shows cancer risks from other progeny detected above background levels. Uranium is the only radionuclide that has a potential risk of greater than $1 \times 10^{-4}$.

Arsenic is not radioactive but is carcinogenic due to its chemical properties. The carcinogenic potential of arsenic is currently under evaluation by the EPA. However, based on the cancer potency previously assigned to arsenic, the expected concentration value of $0.008 \mathrm{mg} / \mathrm{L}$ in ground water would be 
associated with a lifetime excess cancer risk of $4 \times 10^{-4}$, which is above the National Contingency Plan guidance value of $1 \times 10^{-4}$.

Based on the maximum detected concentration, ingesting uranium-contaminated water from the semiconfined aquifer would result in an estimated lifetime excess cancer risk of $4 \times 10^{-6}$, and ingesting garden produce irrigated from the potentially contaminated domestic well would result in an estimated lifetime excess cancer risk of $3 \times 10^{-8}$.

\subsection{LIMITATIONS OF THIS RISK EVALUATION}

The following potential limitations should be noted in interpreting this risk evaluation.

- This risk evaluates only risks related to ground water contaminated with inorganics. Potential contamination with any of the few organic constituents used in uranium processing has not been addressed in this document.

- Populations that might have increased sensitivity, such as the elderly or individuals with preexisting diseases, are not specifically addressed on the toxicity ranges presented on the graphs.

- For reasons not yet been determined, some individuals may be more sensitive to the toxic effects of certain constituents.

- Data available to interpret potential health effects may not always be sufficient to allow accurate determination of all health effects (i.e., lack of testing in humans or testing of dose ranges other than those expected at this site).

- Although plume movement has been evaluated hydrologically and geochemically, the monitoring locations sampled may not be in the most contaminated portion of the plume. Additionally, concentrations may increase or decrease substantially as the plume moves.

- Only the drinking water exposure pathway was considered in depth, although other pathways were screened to determine their contributions, which are small compared to the drinking water ingestion pathway.

The evaluation presented here has considered these limitations and compensated wherever possible by presenting toxicity ranges and probabilistic exposure assessments rather than point estimates, incorporating as much variability as could be reasonably defined. The impact of these potential limitations is discussed more fully in Section 8.2. 


\subsection{LIVESTOCK AND ENVIRONMENTAL EVALUATION}

The objective of the environmental portion of this risk assessment is to determine whether contaminants detected at the site have the potential to adversely affect the existing biological community at or surrounding the site. Currently, the EPA has not issued guidelines for quantifying potential impacts to ecological receptors but has developed a qualitative approach generally used for ecological evaluation (EPA, 1989b). With the qualitative approach, the EPA recommends comparing ambient environmental media concentrations to water quality, sediment quality, or other relevant criteria to determine whether any concentrations the ecological receptors are expected to encounter exceed these criteria.

The effects of contaminants on ecological receptors are of concern; however, it is difficult to predict whether observed effects on specific populations will damage the ecosystem. Populations are dynamic; therefore, information concerning the normal range of variability within a population is important. Although difficult to detect, sublethal effects may be very important to overall ecosystem health le.g., contaminants present at low concentrations may not kill organisms directly but may diminish their ability to survive and reproduce).

\subsection{EXPOSURE CHARACTERIZATION}

This section identifies the potential exposure pathways associated with the site. An exposure pathway generally consists of four elements: a source and mechanism of contaminant release; a retention or transport medium; a point of receptor contact with the contaminated medium; and an exposure route. If any of these elements are missing, exposure cannot occur.

Originally, the source of contamination at the site was the uranium mill and 70-ac (30-ha) tailings pile. However, removal of the tailings pile and associated contaminated soils was completed in 1990 with permanent stabilization in the off-site disposal cell (DOE, 1991). Thus, exposure to tailings or contaminated near-surface soils do not represent an ecological concern at this site.

Currently, the primary source of contamination at the site is the contaminant plume in ground water. Ecological receptors could be exposed to ground water at the site. The shallow depth to ground water may allow plant roots to access soil saturated with contaminated ground water, resulting in plant uptake of contaminants. Plants would also be exposed to contaminants in ground water if ground water were used to irrigate fields or gardens. In addition, livestock watered with ground water drawn from wells are potentially exposed to contaminants. These potential exposure pathways will be evaluated in this assessment.

Surface waters in the site vicinity could be affected if contaminated ground water from the site discharges into area surface waters. In addition, it is possible that contaminants migrated to surface water bodies through surface 
runoff before the tailings pile was removed. Surface waters in the site vicinity that could be affected by site contaminants include the Little Wind River and other water bodies (wetland areas, streams, and drainage ditches) south of the site (Figure 7.1). All these surface water bodies are potential exposure points for resident aquatic life and terrestrial wildlife that may come in contact with surface water or sediment. In addition, terrestrial wildlife may ingest plants or animals that have bioaccumulated contaminants from surface water or ground water. All these potential exposure pathways will be addressed in this risk assessment.

\subsection{ECOLOGICAL RECEPTORS}

This section identifies the ecological resources present at the site and vicinity that are potentially exposed to site-related contaminants.

\subsubsection{Terrestrial flora}

The Riverton tailings site is in an arid, high-desert environment. Vegetation includes shrubs, grasses, and forbs typical of the low desert. The riparian zone along the Wind and Little Wind Rivers contains dense populations of cottonwood, Russian olive, and willow trees. The site, including a large empty field north of the former tailings pile location, has been severely disturbed. As a result, approximately 30 percent of the plant species at the site are of the primary succession type that invade disturbed areas, such as Russian knapweed and Swainson's pea. Typical native species include wheatgrass, sand dropseed, big sagebrush, and rabbitbrush (DOE, 1987). Appendix D of the 1987 environmental assessment conducted for this site (DOE, 1987) lists plant species found at or in the site vicinity.

\subsubsection{Terrestrial fauna}

No comprehensive wildlife surveys or inventories have been conducted for the area around the Riverton site. The marshy areas near the site contain pheasant, chukar, hawk, owl, blackbird, small game, and ground-dwelling rodent populations. Mule deer and white-tailed deer are confined mainly to the riparian zone along the Wind River and brushy drainages approximately $1 \mathrm{mi}(1.6 \mathrm{~km})$ from the site. A large variety of waterfowl, including many riparian species, are found along the rivers and adjacent marshy areas. Canada geese, snow geese, and many duck and shorebird species are common in these areas (DOE, 1987).

During a field survey conducted June 8 and 9,1993 , terrestrial mammals observed in the site vicinity included prairie dogs and a red fox. Signs of beaver, deer, and possibly muskrat were observed in the wetland and riparian areas. Bird species observed in the wetland areas south of the site include numerous red-winged and yellow-headed blackbirds, swallows, eastern kingbirds, a northern oriole, a western tanager, a common yellowthroat, a cormorant, killdeer, American robins, mallard ducks, and herons. 


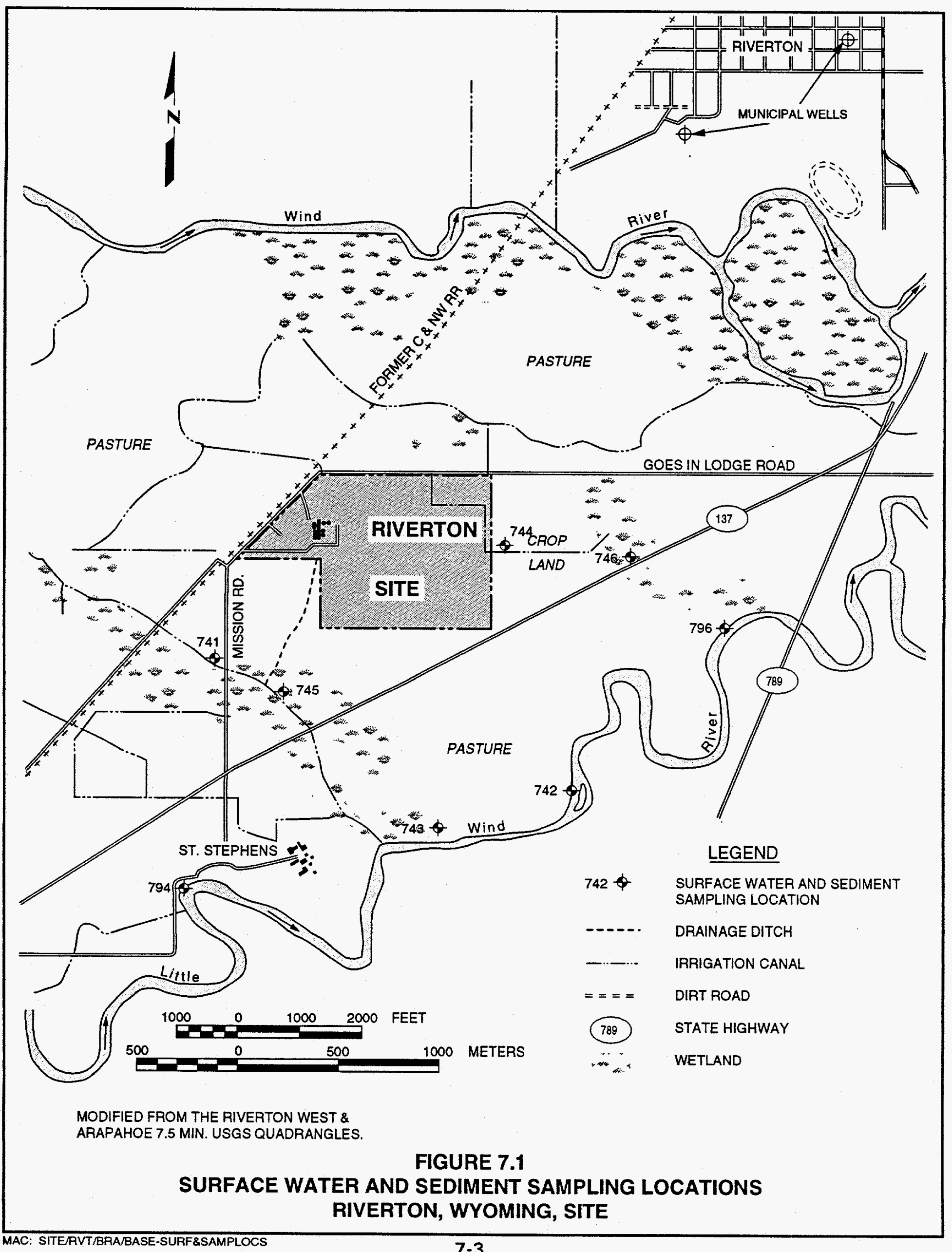


Reptiles found in the area include the short-horned lizard and the fence lizard. The garter snake is likely to occur in the marshy areas adjacent to the site. Depending on seasonal weather conditions and runoff, the marshes contain water intermittently and could provide breeding habitats for amphibians such as the leopard frog and spadefoot toad (DOE, 1987).

Appendix D of the 1987 environmental assessment (DOE, 1987) lists animal species found at or in the vicinity of the Riverton site.

\subsubsection{Aquatic life}

A brief qualitative survey of the aquatic organisms observed in the Little Wind River, the wetland areas, the drainage ditch east of the site, and the unnamed tributary to the Little Wind River was conducted during the June 1993 field survey. A fine-mesh dip net was used to collect fish and benthic macroinvertebrates at these locations.

Sampling location 742 is on the west bank of the river, between sampling locations 794 and 796 (Figure 7.1). The water at sampling location 742 moved more slowly than at the other two sampling locations because the main channel and water flow bypassed the side channel from which the sample was taken. The river's velocity at sampling locations 794 and 796, coupled with its high turbidity at all three locations, limited visual observation to the immediate shoreline area. At sampling locations 794 and 796, the substrate along the shore-water interface was primarily large pebbles and cobbles, with small, isolated areas of sand. The substrate at sampling location 742 was composed of fine-grained sands and silt; no rocks or cobbles were seen. A few small sucker fish, ranging in size from approximately 2 to 3 inches $(5.1$ to $7.6 \mathrm{~cm})$ were caught with a dip net at sampling locations 794 and 796 . Several damselfly and dragonfly nymphs were also collected. The Little Wind River reportedly contains rainbow, brown, and brook trout; three species of suckers (longnose, white, and mountain); carp; flathead chub; and the longnose dace (DOE, 1987).

A wetland area is located approximately $0.25 \mathrm{mi}(0.40 \mathrm{~km})$ southeast (downstream) of Mission Road and just north of the unnamed tributary levee (Figure 7.1). This wetland area is approximately $100 \mathrm{ft}(30 \mathrm{~m})$ long and $40 \mathrm{ft}$ $(12 \mathrm{~m})$ wide, with water depths ranging from less than 1 inch $(2.5 \mathrm{~cm})$ to approximately 20 inches $(50 \mathrm{~cm})$. Sampling location 745 is located at the approximate center. This wetland contained an abundance of filamentous algae and submergent macrophytes. The bottom sediments were covered with algal mats or macrophytes in most areas. Many adult and young-of-the-year minnows were observed. A few large (approximately 2-inch [50-millimeter]) tadpoles were seen, as well as numerous water scavenger beetles. Damselfly and dragonfly nymphs were observed, as well as unidentified amphipods and cladocerans. 
A wetland area approximately $1300 \mathrm{ft}(396 \mathrm{~m})$ east of the site starts just south of Goes In Lodge Road and trends southeast to the Little Wind River

(Figure 7.1). Sampling location 746 is in this wetland area, approximately $25 \mathrm{ft}$ $(7.6 \mathrm{~m})$ north of Highway 137 . No areas of open water were observed in the portion of the wetland that could be seen from the highway. The wetland contained an extremely dense cattail stand. The only aquatic organisms observed were chironomid worms in the sediment.

Observations were also made at the drainage ditch that runs east from the site. This drainage ditch parallels an irrigation canal. Sampling location 744 was $60 \mathrm{ft}(18 \mathrm{~m})$ east of the fence that constitutes the eastern boundary of the site (Figure 7.1). There was no perceptible water flow in this ditch. The water depth ranged from approximately 8 to 12 inches $(20$ to $30 \mathrm{~cm})$. No fish were observed. Water striders, unidentified water fleas, large numbers of mosquito larvae, and small isolated patches of green algae were seen.

The water level was very high in the Little Wind River, which flowed rapidly in the vicinity of sampling locations 794 (upstream location) and 796 (downstream location).

Sampling location 743 is in a drainage area approximately $1500 \mathrm{ft}(457 \mathrm{~m})$ east of St. Stephens Mission and approximately $400 \mathrm{ft}(122 \mathrm{~m})$ north of the Little Wind River. This area is pasture. Because of the high river water, it was flooded during the field survey. Two carp approximately 18 inches $(46 \mathrm{~cm})$ long were observed in this flooded area. These fish probably migrated there from the river. No other aquatic life was observed.

The unnamed tributary is approximately $1250 \mathrm{ft}(380 \mathrm{~m})$ southwest of the site and flows northwest to southeast, eventually joining the Little Wind River approximately $750 \mathrm{ft}(230 \mathrm{~m})$ east of St. Stephens Mission (Figure 7.1). Observations along the reach of this unnamed tributary from $170 \mathrm{ft}(52 \mathrm{~m})$ upstream of Mission Road (sampling location 741) downstream to Highway 137 showed the water was clear, and ranged from approximately 4 inches $(10 \mathrm{~cm})$ deep at sampling location 741 to approximately 24 inches $(61 \mathrm{~cm})$ deep where the tributary flows under Highway 137. The substrate was composed primarily of fine-grained sand interspersed with small rocks in certain areas. The following organisms were observed: water striders, snails, backswimmers, damselfly and dragonfly nymphs, and unidentified minnows. Floating mats of filamentous algae also were observed in this tributary.

\subsection{CONTAMINANTS OF ECOLOGICAL CONCERN}

The list of ground water contaminants that exceed background levels (Table 3.4) was used as the list of contaminants of potential concern in ground water for ecological receptors (e.g., plants).

Before the June 1993 sampling activities, sediment and surface water samples had not been collected from the site vicinity in more than 3 years. Therefore, 
the constituents analyzed in these water bodies were evaluated in this assessment.

7.4 POTENTIAL IMPACTS TO TERRESTRIAL AND AQUATIC LIFE

\subsubsection{Risk to terrestrial life}

\section{Plants}

The contaminant plume in ground water currently represents the primary source of contamination at the site. Because the depth to ground water is shallow, plant roots could extend into the ground water table, resulting in plant uptake of contaminants. In addition, plants may be exposed to contaminants if ground water is used to irrigate fields or gardens. Plants exposed to ground water may accumulate contaminants in various plant parts, which may result in adverse effects.

One way to evaluate plant exposure to chemicals in ground water is to estimate the plant tissue concentrations resulting from uptake of contaminants from ground water and compare these values to toxic levels in mature leaf tissue. Ground water data from monitor well 707 were used to evaluate this pathway, because contaminant concentrations in this well were the highest values observed at the site for most of the contaminants of potential concern.

Constituent partitioning is assumed to occur between ground water and the soil in which the plants are growing. Therefore, a soil concentration was estimated for each contaminant of concern from the mean ground water concentrations by multiplying the water concentrations by a chemical-specific soil-to-water partition coefficient (Kd). Soil concentrations were estimated because only soilto-plant uptake factors are available. The estimated soil concentrations were then multiplied by soil-to-plant uptake factors (Baes et al., 1984), resulting in an estimated plant tissue concentration. Baes et al. (1984) present two types of uptake factors: those used to estimate contaminant concentrations in the vegetative portions of plants (e.g., stems, leaves) and those used to estimate contaminant concentrations in the reproductive portions of plants le.g., fruits, tubers). This assessment estimates concentrations for both the vegetative and reproductive portions of plants. Estimated plant tissue concentrations for the contaminants of potential concern were compared with toxic concentrations in mature leaf tissue (Kabata-Pendias and Pendias, 1992). Table 7.1 presents the results of this comparison.

Where toxicity data were available, all estimated plant tissue concentrations fell below levels shown to be toxic in mature leaf tissue (Table 7.1). However, toxicity data were not available for the following 12 of the 21 contaminants of potential concern: aluminum, bromide, calcium, chloride, iron, magnesium, potassium, silica, sodium, sulfate, strontium, and uranium. 
Table 7.1 Comparison of estimated plant concentrations to phytotoxic concentrations, Riverton UMTRA Project site, Riverton, Wyoming

\begin{tabular}{|c|c|c|c|c|c|c|c|c|}
\hline $\begin{array}{l}\text { Contaminant } \\
\text { of potential } \\
\text { concern }\end{array}$ & $\begin{array}{c}\text { Mean } \\
\text { concentration in } \\
\text { ground water }{ }^{a} \\
\text { (mg/L) }\end{array}$ & $\begin{array}{c}\text { Kd } \\
\text { (L/kg) }\end{array}$ & $\begin{array}{l}\text { Estimated soll } \\
\text { concentration } \\
\text { (mg/kg DW) }\end{array}$ & $\begin{array}{r}\text { Soil } \\
\text { concentr } \\
\text { Bv }\end{array}$ & $\frac{t \text { to-plant }}{\mathrm{Br}}$ & $\begin{array}{c}\text { Estimated } \\
\text { concentration in } \\
\text { vegetative growth } \\
\text { (mg/kg DW) }\end{array}$ & $\begin{array}{c}\text { Estimated } \\
\text { concentration } \\
\text { in fruits/tubers } \\
\text { (mg/kg DW) }\end{array}$ & $\begin{array}{l}\text { Approximate toxic } \\
\text { concentration in } \\
\text { mature leaf tissue } \\
\text { (mg/gram DW) }^{\text {b }}\end{array}$ \\
\hline Aluminum & 0.14 & 1500 & $2.1 E+02$ & 0.004 & 0.00065 & 0.8 & 0.14 & NA \\
\hline Arsenic & 0.011 & 200 & 2.1E + 00 & 0.04 & 0.006 & 0.08 & 0.013 & $5-20$ \\
\hline Boron & 0.20 & 3 & 6.OE-01 & 4 & 2 & 2.4 & 1.2 & $50-200$ \\
\hline Bromide & 0.22 & 7.5 & $1.6 \mathrm{E}+00$ & 1.5 & 1.5 & 2.4 & 2.4 & NA \\
\hline Calcium & 40 & 4 & $1.6 \mathrm{E}+03$ & 3.5 & 0.35 & 5600 & 560 & NA \\
\hline Chloride & 120 & 0.25 & $3.0 E+01$ & 70 & 70 & 2100 & 2100 & NA \\
\hline Fluoride & 0.80 & 150 & $1.2 E+02$ & 0.06 & 0.006 & 7.2 & 0.72 & $50-500$ \\
\hline Iron & 0.35 & 25 & $8.8 E+00$ & 0.004 & 0.001 & 0.035 & 0.0088 & NA \\
\hline Magnesium & 200 & 4.5 & $9.1 E+02$ & 1 & 0.55 & 910 & 500 & NA \\
\hline Manganese & 4.9 & 65 & $3.2 E+02$ & 0.25 & 0.05 & 80 & 16 & $200^{c}-1000$ \\
\hline Molybdenum & 0.79 & 20 & $1.6 \mathrm{E}+01$ & 0.25 & 0.06 & 4.0 & 0.96 & $10-50$ \\
\hline Nickel & 0.16 & 150 & $2.4 \mathrm{E}+01$ & 0.06 & 0.06 & 1.4 & 1.4 & $10-100$ \\
\hline Potassium & 14.3 & 5.5 & $7.9 E+01$ & 1 & 0.55 & 79 & 43 & NA \\
\hline Selenium & 0.022 & 300 & $6.6 \mathrm{E}+00$ & 0.025 & 0.025 & 0.17 & 0.17 & $5-30$ \\
\hline Silica & 29 & 30 & $8.6 \mathrm{E}+02$ & 0.35 & 0.07 & 300 & 60 & NA \\
\hline Sodium & 900 & 100 & $9.0 E+04$ & 0.075 & 0.055 & 6800 & 5000 & NA \\
\hline Sulfate & 3100 & 7.5 & $2.3 E+04$ & 0.5 & 0.5 & 12,000 & 12,000 & NA \\
\hline Strontium & 2.5 & 35 & $8.8 E+01$ & 2.5 & 0.25 & 220 & 22 & NA \\
\hline Uranium & 1.2 & 450 & $5.4 E+02$ & 0.0085 & 0.004 & 4.6 & 2.2 & NA \\
\hline Vanadium & 0.030 & 1000 & $3.0 E+01$ & 0.0055 & 0.003 & 0.17 & 0.09 & $5-10$ \\
\hline Zinc & 0.0075 & 40 & 3.00E-01 & 1.5 & 0.9 & 0.45 & 0.3 & $100-400$ \\
\hline
\end{tabular}

aData from monitor well 707.

${ }^{b}$ Concentrations are not presented for very sensitive or for highly tolerant plant species (Kabata Pendias and Pendias, 1992).

${ }^{C}$ The value of $200 \mathrm{mg} / \mathrm{kg}$ is a recommended criterion of the Illinois Institute of Environmental Quality (Saric, 1986).

Bv - Soil-to-plant uptake factor for vegetative portions (e.g., leaves, stems) of plants (Baes et al., 1984).

$\mathrm{Br}$ - Soil-to-plant uptake factor for reproductive portion (e.g., fruits, tubers) of plants (Baes et al., 1984).

Kd - Soil-to-water partition coefficient (Baes et al., 1984).

DW - Dry weight.

NA - Not available. 
Potential effects on plants exposed to ground water were also evaluated by comparing mean ground water concentrations to concentrations in continuously applied irrigation water reported to be protective of plants. The water concentrations protective of plants were developed for agricultural purposes (EPA, 1972). Table 7.2 presents the results of this comparison, showing that manganese and molybdenum concentrations could build up to toxic levels in the soil following long-term use. Because comparison values were not available for 10 contaminants of potential concern (bromide, calcium, chloride, magnesium, potassium, silica, sodium, sulfate, strontium, and uranium), the plant toxicity of these contaminants cannot be evaluated.

Another way to evaluate the suitability of the ground water for plants is to evaluate the water's total soluble salt content. Excess salts in water increase the osmotic pressure of a soil solution, creating a physiological drought condition in plants growing in the soil. The total soluble salt content of water can be measured by its specific conductance (electrical conductivity). The mean specific conductance from monitor well 707 is 3730 micromhos per centimeter (micromhos $/ \mathrm{cm}$ ). This value falls above the upper end of the acceptable range (1500 to 3000 micromhos $/ \mathrm{cm}$ ) for water that may have adverse effects on many crops; using this water would require careful management (Follett and Soltanpour, 1985).

\section{Wildlife}

Wildlife may be exposed to contaminants from the site by ingesting surface water that has received site contamination in runoff or ground water discharge. However, state and federal criteria or standards have not been established for the protection of terrestrial wildlife from water exposure. Thus, this potential exposure pathway was not evaluated.

Wildlife also may be exposed to contaminants by ingesting plants or other animals that have bioaccumulated site contaminants (e.g., birds eating aquatic macroinvertebrates). Standards or guidelines are not available to evaluate this potential exposure pathway.

Biomagnification refers to the tendency of some chemicals to accumulate in higher concentrations at higher levels of the food chain through diet. Top predators, especially carnivorous birds and mammals, are of particular concern in determining the effects of biomagnification.

\subsubsection{Risk to aquatic life}

\section{Little Wind River}

Aquatic life in the Little Wind River may be exposed to contaminants associated with the site. It is possible that contaminants from the ground water plume at the site are discharging to the Little Wind River or that surface water runoff washed contaminants into the river before the tailings were removed. 
Table 7.2 Comparison of contaminants of potential concern in ground water with available water quality values, Riverton UMTRA Project site, Riverton, Wyoming

\begin{tabular}{|c|c|c|c|}
\hline $\begin{array}{c}\text { Contaminant of } \\
\text { potential } \\
\text { concern }\end{array}$ & $\begin{array}{c}\text { Mean } \\
\text { concentration in } \\
\text { ground water }{ }^{\mathrm{a}} \\
(\mathrm{mg} / \mathrm{L})\end{array}$ & $\begin{array}{c}\text { Water concentration } \\
\text { protective of livestock } \\
\text { (mg/L) }\end{array}$ & $\begin{array}{c}\text { Water concentration } \\
\text { protective of plants } \\
(\mathrm{mg} / \mathrm{L})\end{array}$ \\
\hline Aluminum & 0.14 & 5.0 & 50 \\
\hline Arsenic & 0.011 & 0.2 & 0.10 \\
\hline Boron & 0.20 & 5.0 & 0.75 \\
\hline Bromide & 0.22 & NA & NA \\
\hline Calcium & 410 & NA & NA \\
\hline Chloride & 120 & NA & NA \\
\hline Fluoride & 0.80 & 2.0 & 1.0 \\
\hline Iron & 0.35 & NA & 5.0 \\
\hline Magnesium & 200 & NA & NA \\
\hline Manganese & 4.9 & NA & 0.20 \\
\hline Molybdenum & 0.79 & $10^{c}$ & 0.01 \\
\hline Nickel & 0.16 & NA & 0.20 \\
\hline Potassium & 14 & NA & NA \\
\hline Selenium & 0.022 & 0.05 & 0.02 \\
\hline Silica & 29 & NA & NA \\
\hline Sodium & 900 & NA & NA \\
\hline Sulfate & 3100 & $1000^{d}$ & NA \\
\hline Strontium & 2.5 & NA & NA \\
\hline Uranium & 1.2 & NA & NA \\
\hline Vanadium & 0.030 & 0.1 & 0.10 \\
\hline Zinc & 0.0075 & 25 & 2.0 \\
\hline
\end{tabular}

aData from monitor well 707.

bEPA (1972), unless specified otherwise.

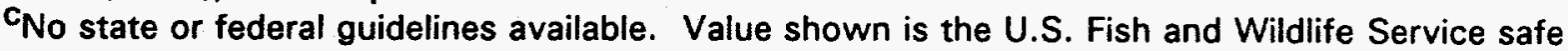
level for cattle (Eisler, 1989).

dNational Research Council (1971).

NA - not available. 


\section{Little Wind River water}

As discussed previously, there are three sampling locations on the Little Wind River: 794 (background), 742, and 796 (see Figure 7.1). These stations were last sampled in June 1993. Surface waters were analyzed for calcium, iron, magnesium, manganese, molybdenum, lead, and uranium. These samples were not filtered and thus represent total metals in the surface waters. These data were compared with available chronic federal water quality criteria (FWOC) for the protection of aquatic life (EPA, 1986). The ambient water quality criteria for the state of Wyoming do not differ from the FWOC for the constituents evaluated in surface waters at the site (WDEQ, 1990).

Surface water data from the Little Wind River collected in the June 1993 sampling event are shown in Table 7.3. Because molybdenum was not detected in surface waters, a comparison for molybdenum was not necessary. Of the remaining constituents, FWOC were available only for iron and lead. Iron concentrations at all three river sampling locations exceeded the criterion of $1.0 \mathrm{mg} / \mathrm{L}$, including the background location. The highest iron concentration was found at sampling location 796, which exceeded the criterion by a factor of 3. However, it should be noted that iron concentrations in upstream and downstream sampling locations. were not significantly different. The criterion for lead, $0.0058 \mathrm{mg} / \mathrm{L}$, is hardness-dependent and was calculated using an average hardness for the Little Wind River of $161 \mathrm{mg} / \mathrm{L}$ as $\mathrm{CaCO}_{3}$. Lead concentrations measured in the Little Wind River did not exceed this criterion. In addition, the downstream lead concentrations were the same as the concentration measured at the background location.

Uranium concentrations at sampling location 742 exceeded background by more than 1 order of magnitude and may thus represent an ecological concern. This sampling location is closest to the highest chemical levels detected in ground water (monitor well 707). Farther downstream at sampling location 796 , uranium concentrations decline to background levels.

FWOC were not available for calcium. However, calcium probably is not of ecological concern in surface waters at this site because the downstream calcium concentrations are similar to the background concentration.

Historical data collected from August 1987 through March 1990 are available . for sampling locations 794 and 796. Samples from these locations were analyzed for $\mathbf{4 5}$ metals and radionuclides. Most of the samples were filtered. However, one sample taken at sampling location 796 in March 1990 was unfiltered. A comparison of the data at sampling location 796 (filtered) with the data from sampling location 794 (background) shows that most concentrations at sampling location 796 fall below background levels. Five constituents essentially were at background levels, but six slightly exceeded the background levels: calcium, chloride, lead-210, mercury, strontium, and sulfate. Three constituents (radium-226, radium-228, and uranium) in the earlier sampling rounds exceeded background levels but in the later rounds either fell below 
Table 7.3 Occurrence of constituents in the Little Wind River surface water, June 1993 sampling event, Riverton UMTRA Project site, Riverton, Wyoming

\begin{tabular}{lccc}
\hline $\begin{array}{c}\text { Contaminant of } \\
\text { potential concern }\end{array}$ & $\begin{array}{c}\text { Location ID 794 } \\
\text { (background) }\end{array}$ & Location ID 742 & Location ID 796 \\
\hline Calcium & 41 & 41 & 42 \\
Iron & 2.0 & 1.4 & 3.1 \\
Magnesium & 14 & 14 & 14 \\
Manganese & 0.09 & 0.12 & 0.14 \\
Molybdenum & ND & ND & ND \\
Lead & 0.004 & 0.004 & 0.004 \\
Uranium & 0.002 & 0.025 & 0.002 \\
\hline
\end{tabular}

All concentrations reported in milligrams per liter.

ND - not detected.

background levels or only slightly exceeded background. Historical data show a total uranium concentration of $0.0088 \mathrm{mg} / \mathrm{L}$ at sampling location 796 in March 1990. In June 1993, the level of total uranium measured at this same location was $0.002 \mathrm{mg} / \mathrm{L}$, showing a slight decline in concentration.

\section{Little Wind River sediment}

No tribal, state, or federal sediment quality criteria (SOC) have been established for the protection of aquatic life. Although the EPA has developed interim SOC for several nonpolar hydrophobic organic compounds (EPA, 1988), no such SQC have been developed for the contaminants of potential concern at this site.

In the absence of SQC, effects-based sediment guidelines available from the National Oceanic and Atmospheric Administration (NOAA) (NOAA, 1990) were compared to the chemicals detected in sediments of the Little Wind River. The NOAA sediment-effects values were developed to determine which chemical concentrations are likely to result in adverse effects, based on established data. The effects range-low (ER-L) values are concentrations equivalent to the lower 10th percentile of available data screened by NOAA and indicate the low end of the concentration range in which adverse effects were observed or predicted.

The sediment data collected at the three sampling locations on the Little Wind River in June 1993 are shown in Table 7.4. Of the five constituents analyzed, a NOAA value was available only for lead. The levels of lead detected in Little Wind River sediments fall below the ER- $L$ value of $35 \mathrm{mg} / \mathrm{kg}$. Guidelines were not available with which to assess the potential ecological effects of iron, manganese, molybdenum, and uranium in sediments at the site. With the 
exception of molybdenum, concentrations of these constituents did exceed background levels, with the highest concentrations measured at sampling location 742. Molybdenum was not detected at the background location (794) or at location 742.

Table 7.4 Occurrence of constituents in the Little Wind River sediments, June 1993 sampling event, Riverton UMTRA Project site, Riverton, Wyoming

\begin{tabular}{lccc}
\hline \multicolumn{1}{c}{ Constituent } & $\begin{array}{c}\text { Location ID 794 } \\
\text { (background) }\end{array}$ & Location ID 742 & Location ID 796 \\
\hline Iron & 5900 & 21,000 & 8500 \\
Manganese & 170 & 620 & 210 \\
Molybdenum & ND & ND & 4.0 \\
Lead & 4.5 & 14 & 3.9 \\
Uranium & 2.0 & 10 & 2.3 \\
\hline
\end{tabular}

All concentrations reported in milligrams per kilogram.

ND - not detected.

\section{Other water bodies}

Several other surface water bodies in the site vicinity may be potential exposure points for aquatic life. It is possible that contaminants from the ground water plume at the site discharge to these areas or that contaminants washed into these areas through surface water runoff before the tailings were removed.

\section{Surface water}

During the June 1993 sampling event, five areas were sampled and surface waters were analyzed for calcium, iron, magnesium, manganese, molybdenum, lead, and uranium. The samples were not filtered and thus represent total metals in the surface waters.

Table 7.5 presents the surface water data from the five sample locations. These data were compared with available chronic FWOC for the protection of aquatic life. Because lead was not detected in surface waters, comparisons were not applicable. Neither were comparisons applicable for molybdenum, which was detected only at the background location. For the remaining chemicals, an FWOC was available only for iron. Iron concentrations did not exceed the FWOC of $1.0 \mathrm{mg} / \mathrm{L}$ at any sampling locations. 
Table 7.5 Occurrence of constituents in surface water from water bodies in the site vicinity, June 1993 sampling event, Riverton UMTRA Project site, Riverton, Wroming

\begin{tabular}{lccccc}
\hline \multicolumn{1}{c}{ Constituant } & $\begin{array}{c}\text { Location ID 741 } \\
\text { (background) }\end{array}$ & $\begin{array}{c}\text { Location ID } \\
\mathbf{7 4 3}\end{array}$ & $\begin{array}{c}\text { Location ID } \\
\mathbf{7 4 4}\end{array}$ & $\begin{array}{c}\text { Location ID } \\
\mathbf{7 4 5}\end{array}$ & $\begin{array}{c}\text { Location ID } \\
\text { 746 }\end{array}$ \\
\hline Calcium & $46-70$ & 160 & 58 & 81 & 110 \\
Iron & $0.43-0.46$ & 0.24 & 0.13 & 0.36 & 0.09 \\
Magnesium & $13-20$ & 38 & 14 & 22 & 39 \\
Manganese & $0.05-0.05$ & 0.12 & 0.02 & 0.05 & 0.06 \\
Molybdenum & ND-0.02 & 0.01 & ND & ND & ND \\
Lead & ND & ND & ND & ND & ND \\
Uranium & $0.006-0.006$ & 0.013 & 0.016 & 0.008 & 0.008 \\
\hline
\end{tabular}

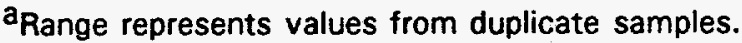

ND - not detected.

FWQC were not available for calcium, magnesium, manganese, and uranium. Sampling location 743 had the highest calcium concentration, exceeding the maximum background level by a factor of 2.3. Where measured concentrations are similar to background concentrations, however, these concentrations probably do not represent an ecological concern, nor can they be attributed to contaminants from the site. Many concentrations measured for these constituents were similar to background levels. The detected concentrations exceeded maximum background concentrations at most by a factor of 2 to 2.5 . Based on the limited data available, the significance of such an increase is uncertain.

\section{Sediment}

Table 7.6 shows the sediment data collected in June 1993 at the five sampling locations. Of the five constituents analyzed in the sediments, a NOAA value was available only for lead. Lead levels detected at sampling location 746 exceeded the NOAA ER-L of $35 \mathrm{mg} / \mathrm{kg}$. This sampling station is only a few feet from Highway 137. Therefore, although this lead concentration may result in ecological effects, the source of this lead probably is related to automobile exhaust fumes from the highway rather than from activities at the Riverton site. Sediment guidelines were not available to assess the potential ecological effects of iron, manganese, molybdenum, and uranium in sediments at the site. However, because manganese and molybdenum concentrations did not exceed maximum concentrations measured at the background location, they probably are not of concern. Iron and uranium exceeded maximum background concentrations by a factor of 1.5 at most. The significance of this increase above background is not known. 
Table 7.6 Occurrence of constituents in sediments from water bodies in the site vicinity, June 1993 sampling event, Riverton UMTRA Project site, Riverton, Wyoming

\begin{tabular}{|c|c|c|c|c|c|}
\hline Constituent & Location ID $741^{a}$ & $\begin{array}{c}\text { Location ID } \\
743 \\
\end{array}$ & $\begin{array}{c}\text { Location ID } \\
744 \\
\end{array}$ & $\begin{array}{c}\text { Location ID } \\
\quad 745 \\
\end{array}$ & $\begin{array}{c}\text { Location ID } \\
746\end{array}$ \\
\hline Iron & $3000-11,000$ & 18,000 & 12,000 & 3200 & 11,000 \\
\hline Lead & $3.6-11$ & 21.9 & 6.0 & 4.8 & 68 \\
\hline Manganese & $180-460$ & 240 & 190 & 54 & 310 \\
\hline Molybdenum & ND-11 & 2.0 & ND & 1.0 & 9.0 \\
\hline Uranium & $1.9-7.6$ & 5.0 & 5.5 & 1.7 & 11 \\
\hline
\end{tabular}

a Range represents duplicate sample taken at this location.

All concentrations reported in milligrams per kilogram. ND - not detected. 


\subsection{POTENTIAL IMPACTS TO LIVESTOCK}

Both cattle and horses are raised in the site vicinity. Currently, some residents water their livestock with ground water. To evaluate the potential impact to livestock that may be exposed to ground water contaminants, the concentrations detected in monitor well 707 were compared to drinking water concentrations considered protective of livestock (EPA, 1972; Eisler, 1989). Data from monitor well 707 were used to evaluate livestock exposure because contaminant concentrations in this well were the highest values observed at the site for most contaminants.

Comparison values for livestock were available for 9 of the 21 contaminants of potential concern in ground water. Results of the comparison (Table 7.2) show that the mean sulfate concentration in ground water exceeds by a factor of about 3 the water concentrations determined to be protective of livestock. Thus, watering livestock with ground water may cause adverse effects.

Information was not sufficient to evaluate the following 12 contaminants: bromide, calcium, chloride, iron, magnesium, manganese, nickel, potassium, silica, sodium, strontium, and uranium. Therefore, the potential effects on livestock from the intake of these chemicals could not be evaluated with available information.

\subsection{LIMITATIONS OF THE ECOLOGICAL RISK ASSESSMENT}

The qualitative evaluation presented here of potential ecological risks is a screening level assessment of the risks associated with potential exposure of plants and animals to contaminated ground water, surface water, and sediment at the Riverton site. Sources of uncertainty in any ecological assessment arise from the monitoring data, exposure assessments, toxicological information, and the inherent complexities of the ecosystem. In addition, methods are often unavailable for predicting nonchemical stresses (e.g., drought), biotic interactions, behavior patterns, biological variability (e.g., nutrient availability or differences in physical conditions), and resiliency and recovery capacities. The Riverton ecological risk assessment includes the following general limitations:

- Only a small amount of ecological data was collected during this screening.

- Little is known about site-specific intake rates for wildlife or amounts of contaminants taken up by plants. General literature values were used in many cases.

- Only limited ecotoxicological reference data are available.

- Considerable uncertainty is associated with the toxicity of mixtures of contaminants. 


\subsection{SUMMARY}

Comparing mean ground water concentrations with water concentrations protective of plants indicates that manganese and molybdenum are at concentrations that could adversely affect plants. Thus, plants whose roots may contact ground water-saturated soil or plants irrigated with ground water could be affected by levels of these contaminants of potential concern in ground water.

Essentially, no data were available to evaluate the effects of exposure on terrestrial wildlife species.

The surface water concentrations for iron detected in the Little Wind River exceed available FWOC. However, for most constituents analyzed in surface waters, the downstream location differed little from concentrations at the background location. The downstream location is approximately $9000 \mathrm{ft}(2740$ $\mathrm{m}$ ) downriver from the background location. The uranium concentration measured at sampling location 742 is approximately 1 order of magnitude higher than the background concentration and could represent an ecological concern. This sampling location is closest to the highest contaminant levels detected in ground water. Farther downstream at sampling location 796, uranium concentrations decline to background levels.

An evaluation of sediment data from the Little Wind River showed that downstream concentrations exceeded background concentrations, with the highest concentrations observed at sampling location 742. This is the same location at which higher uranium values were observed in surface waters. Sediment quality values were available only for lead. The sediment lead concentrations did not exceed the sediment quality values.

In other water bodies in the site vicinity, the surface water concentrations did not exceed FWOC. Since FWOC are not available for several constituents, however, it is not certain whether any of these concentrations threaten aquatic organisms. At most, the concentrations exceeded maximum background concentrations by a factor of 2 to 2.5. No clear trend is associated with surface water concentrations in these areas. The locations of highest values varied for the different constituents.

A comparison of sediment quality values with sediment data from these areas shows that the lead concentration at sampling location 746 exceeds the NOAA ER-L. Because this sampling location is only a few feet from Highway 137, these concentrations probably are due primarily to automobile exhaust fumes rather than site-related activities. Sediment quality values were not available for any other constituents detected in sediments. Manganese and molybdenum concentrations did not exceed background concentrations, and concentrations of the other constituents exceeded maximum background concentrations by a factor of 1.5 at most. No clear trend is associated with sediment 
concentrations in these water bodies. The locations of highest values varied for the different constituents.

Potential exposure to livestock that ingest ground water was evaluated by comparing mean ground water concentrations to water concentrations determined to be protective of livestock. Based on the sulfate concentrations in ground water, the results showed that adverse effects could occur because the mean sulfate ground water concentration was 3 times greater than the guidance value.

Water and sediment quality criteria and/or guideline values were insufficient to comprehensively evaluate the impact of ground water, surface water, and sediments on ecological receptors. Therefore, this assessment of ecological risk could evaluate only some of the constituents detected at the site. 


\subsection{INTERPRETATION AND RECOMMENDATIONS}

8.1

\section{RISK SUMMARY}

The UMTRCA requires the UMTRA Project to protect public health and the environment from radiological and nonradiological hazards associated with the former uranium mill sites. This baseline risk assessment of the Riverton site was conducted to evaluate the presence of these hazards. Because contaminated ground water is not currently used for drinking water by area residents, human health is currently not at risk. Although one domestic irrigation well showed very low levels of contamination, these levels are not associated with adverse health effects for these uses. Future drinking water use of contaminated ground water could, however, be associated with adverse health effects.

Using the surficial aquifer as a source of drinking water would cause an unacceptable risk of $3 \times 10^{-4}$ for uranium and $4 \times 10^{-4}$ for arsenic, exceeding the EPA National Contingency Plan guideline of a maximum of $1 \times 10^{-4}$ lifetime excess cancer risk. Potential noncarcinogenic health effects from exposure to uranium would also be of concern, as would exposure to molybdenum, manganese, and sulfate. Although these exposures are not in the range that cause lethal effects, they would probably result in adverse health effects such as diarrhea (sulfate), neurologic changes (manganese), and biochemical imbalances (molybdenum, manganese, and sulfate).

Using contaminated ground water from the surficial aquifer to irrigate crops or gardens or to water livestock is not anticipated to result in human health risks. Adverse human health effects would not be expected to follow ingestion of milk or meat from animals grazed and watered on the pastureland downgradient of the site or from ingestion of garden produce watered with the contaminated ground water.

Based on available data, recreational use (ingestion of fish and incidental ingestion of surface water and sediments) of the Little Wind River in the site vicinity is not expected to result in adverse human health effects.

The contaminated ground water near the processing site would not be acceptable as a source of continuous irrigation water for agricultural crops. In addition, the adverse effects of sulfate may make the ground water unsuitable as a sole source of drinking water for livestock.

Contaminated ground water could potentially affect the environment. Based on data from monitor wells near the river and surface water and sediment quality data, it appears that contaminated ground water has reached the Little Wind River. However, water and sediment quality criteria and/or guidelines were insufficient to comprehensively evaluate the impact of ground water, surface 
water, and sediments on ecological receptors. Therefore, this assessment of ecological risk could evaluate only some constituents detected at the site.

The following limitations to this health risk evaluation should be noted:

- This document evaluates risks associated only with exposure to inorganic contaminants of ground water at the UMTRA Project site near Riverton. Potential organic contaminants (those few related to uranium processing) have not been considered.

- In general, the results presented in this document are based on filtered (0.45-micrometer) water samples. The effect of filtration differs for different elements: e.g., filtering uranium and sulfate results in only slight differences, whereas filtering manganese can significantly underestimate levels present. Constituents in suspension can be lost with filtration but still produce toxic effects if ingested and broken down in the acidic environment of the stomach.

- The toxicity of contaminants varies from individual to individual. This assessment emphasizes that variability by using the probability distributions for potential exposure and by presenting exposure ranges that can produce toxic effects. Additionally, data used to determine toxicity were obtained by testing laboratory animals at exposure doses different from those expected at the site. The relationship between dose and response is not always linear, and humans and animals do not always exhibit similar toxic effects.

- To assess toxicity, standardized reference values (developed by various agencies) and literature values were used to determine plant uptake, tissue concentrations in livestock, and toxic effects in humans. These reference values are limited: whereas exposure to multiple chemicals occurs simultaneously, toxicity, uptake, and bioconcentration data are not available for all constituents, and data used to determine toxicity are generally based on exposure to only one chemical. The interactive effects of multiple constituents and the impact of these interactions on expected toxicity generally cannot be assessed from existing data.

- Although considerable effort has been directed at determining plume movement and locating monitor wells to identify maximum contamination, variability in physical systems and models used to determine contaminant plume migration could still result in well placements that do not measure the highest contaminant concentrations or determine the fullest extent of plume impact.

- Variability can be introduced through sampling and analytical processes. However, the data at UMTRA Project sites have been collected over many 
years and subjected to rigorous quality assurance procedures. The use of multiple samples introduces high confidence in the reliability and validity of the collected data.

- The drinking water pathway is considered the major determinant of exposure in this assessment. Although other pathways were screened and determined not to contribute significantly to the total exposure, the additivity of exposure from these pathways should be kept in mind. The potential risk contributions from the additional ground water exposure pathways (dermal absorption, ingestion of irrigated produce, and ingestion of meat and milk from livestock that drink the ground water) were reviewed to verify that those pathways are not significant relative to the drinking water pathway.

Nonetheless, by presenting ranges of toxic effects, probable exposure distributions, summaries of available data on health effects and interactions, and outlines of potential limitations, this document realistically interprets the potential health risks associated with use of contaminated ground water at this site. Based on available data, this assessment is designed to accurately describe contamination, risk, and uncertainties.

\subsection{GROUND WATER CRITERIA}

In 1983, the EPA established health and environmental protection standards for the UMTRA Project; in 1987, the EPA proposed revised ground water standards. The UMTRA Project is required to adhere to the 1987 proposed ground water standards until final standards are published. The ground water standards consist of 1) ground water protection standards to evaluate disposal cell performance, and 2) ground water cleanup standards for existing contamination at processing sites. Table $\mathbf{8 . 1}$ summarizes these standards for contaminants that have proposed maximum concentration limits (MCL). Because an MCL is not established for every contaminant, the proposed standard requires meeting background levels for contaminants that do not have MCLs. In some circumstances, an alternate concentration limit $(A C L)$ may replace background or MCL standards.

While the UMTRCA standards apply only to the UMTRA Project, the EPA has published drinking water health advisory levels for both long-term and shortterm exposures (Table 8.1). Molybdenum, nickel, uranium, and vanadium have consistently exceeded these levels at this site.

\subsection{RISK MITIGATION MEASURES}

This section presents possible ways to restrict ground water access and thus mitigate the risk of adverse health effects.

Institutional controls (controlling access to contaminated ground water) are defined in the UMTRA Project's proposed ground water standards as 
Table 8.1 Concentration limits of constituents

\begin{tabular}{|c|c|c|c|}
\hline Constituent & $\begin{array}{c}\text { UMTRCA MCL } \\
40 \text { CFR } \$ 192.02 \\
\text { (mg/L) }\end{array}$ & $\begin{array}{l}\text { EPA health advisories } \\
\text { 10-kg child, 10-day } \\
\text { (mg/L) }\end{array}$ & $\begin{array}{l}\text { EPA health advisories } \\
\text { 70-kg adult lifetime } \\
\text { (mg/L) }\end{array}$ \\
\hline \multicolumn{4}{|l|}{ Chemicals (inorganic) } \\
\hline Antimony & - & $0.015^{b}$ & $0.003^{c}$ \\
\hline Arsenic & 0.05 & - & - \\
\hline Barium & 1.0 & - & 2 \\
\hline Boron & - & 0.9 & 0.6 \\
\hline Cadmium & 0.01 & 0.04 & 0.005 \\
\hline Chromium & $0.05^{c}$ & 1.0 & $0.1^{b}$ \\
\hline Lead & 0.05 & - & $0.015^{b}$ \\
\hline Manganese & - & - & $0.18^{d}$ \\
\hline Mercury & $0.002^{c}$ & - & - \\
\hline Molybdenum & $0.1^{b}$ & $0.08^{b}$ & $0.04^{b}$ \\
\hline Nickel & - & 1.0 & $0.1^{b}$ \\
\hline Nitrate & $44^{e}$ & $44^{f}$ & - \\
\hline Selenium & $0.01^{b}$ & - & - \\
\hline Silver & 0.05 & 0.2 & 0.1 \\
\hline Strontium & - & 25.0 & 17 \\
\hline Sulfate & - & - & $400^{9}$ \\
\hline Thallium & - & 0.007 & 0.0004 \\
\hline Vanadium & - & $0.08^{b}$ & $0.02^{c}$ \\
\hline Zinc & - & 6.0 & 2 \\
\hline \multicolumn{4}{|l|}{ Radionuclides } \\
\hline Radium-226/-228 & $5 \mathrm{pCi} / \mathrm{L}$ & - & - \\
\hline $\begin{array}{l}\text { Uranium (U-234/ } \\
-238)\end{array}$ & $\begin{array}{c}30 \mathrm{pCi} / \mathrm{L}^{\mathrm{b}} \\
(0.044 \mathrm{mg} / \mathrm{L})\end{array}$ & $0.03 \mathrm{mg} / \mathrm{L}^{h}$ & $0.03 \mathrm{mg} / \mathrm{L}^{h}$ \\
\hline
\end{tabular}

${ }^{\text {Aaction level for lead. }}$

${ }^{b}$ Exceeded in plume wells.

Exceeded in background and plume wells in surficial aquifer.

d Chronic drinking water equivalent level.

Equal $10 \mathrm{mg} / \mathrm{L}$ nitrate as nitrogen.

fUnder review.

${ }^{9}$ Acute drinking water equivalent level (EPA, 1992).

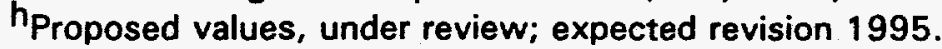


mechanisms to effectively protect human health and the environment. Although the proposed standards refer to establishing institutional controls for long periods of time (e.g., up to 100 years during natural flushing), this concept can also be applied to short-term or interim restriction of access to ground water. Because it will take years to characterize ground water at the Riverton site, institutional controls may be needed before remedial action decisions are made.

The proposed EPA standards require permanent government entities to implement institutional controls. The Wind Rivers Tribes' Environmental Quality Commission has negotiated with the state of Wyoming to define its role in administering ground water activities on the reservation (Stockdale, 1993). The negotiations, held during the summer of 1993, and the development of tribal water quality standards may help determine appropriate site-specific institutional controls.

Currently, the state administers a permitting process for the installation of new wells on tribal lands. Water quality testing is voluntary for owners of new wells; some analytical results are attached to well completion reports and sent to the state. There is no minimum acreage restriction for new wells.

Some wells installed on tribal lands were not permitted by the state. The Wind River Environmental Quality Commission tabulates all wells on tribal lands. Tribal engineers conduct technical review of well installations to lessen the potential for aquifer cross-contamination and to confirm that wells have been constructed and installed correctly. Until the Wind River Tribes develop their own water quality standards and regulations, the tribal water quality requirements must comply with EPA standards (Hart, 1993).

The Wyoming Engineer's Office of Regulations and Instructions, Part II Ground Water, Section 16, provides for the designation of control areas by the Wyoming Board of Control. Control areas can be imposed if ground water levels are declining, if ground water use is approaching current recharge rate, or if "other conditions exist or . . . arise that require regulation for the protection of the public interest." To establish a new control area, the state engineer reports to the state Board of Control, proposing the control area and describing why a control area should be established. After a public hearing, the state Board of Control evaluates the testimony and either designates a control area or rejects the proposal.

Section 16 provides for the election of a Control Area Advisory Board composed of five control area residents to advise and assist the state engineer in formulating policies concerning ground water development in the control area. The advisory board provides a means by which regulations for the use of ground water can be developed and implemented, should they be needed. When a control area is established, a Control Area Advisory Board is elected and the appropriate water division superintendent adjudicates all ground water rights within the designated control area. The state engineer may then establish 
necessary controls and regulations with the advice of the Control Area Advisory Board and the Division Advisory Committee on Ground Water.

Establishing interim institutional controls to ensure the protection of human health and the environment will require a consensus among the Arapaho and Shoshone Tribes and other governmental agencies. Local authorities will need to monitor new wells and ensure that they have been approved. Governing authorities will need to be informed of monitoring results and the expected duration of contamination problems. The DOE, the state of Wyoming, and environmental officials from both tribes should work together to educate local residents about potential risks and the need for access restrictions.

\subsection{RECOMMENDATIONS}

In general, the proposed ground water standards (consisting of MCLs or background concentrations) are sufficient to protect human health and the environment. In some cases, however, a risk assessment may identify site-specific factors indicating that these standards may be either too restrictive or not restrictive enough. When standards are too restrictive, there may be no potential for exposure and a less restrictive ACL may be sought. In other cases, the standards may not be sufficiently protective (e.g., if many contaminants near their MCLs have additive or synergistic adverse health effects).

There is no permanent physical barrier to prevent access to contaminated ground water at the former Riverton processing site area. Therefore, ACLs could not be justified for those constituents with MCLs. However, for constituents that exceed background levels and do not have MCLs, this assessment suggests that background levels are more restrictive than necessary. ACLs should be sought for those contaminants screened because their concentrations fall within nutritional levels (e.g., iron, zinc), and other contaminants, such as nickel and vanadium, whose concentrations fall well below adverse health effect levels.

The levels of arsenic, manganese, molybdenum, sulfate, and uranium in the surficial aquifer between the former processing site and the Little Wind River could be associated with adverse health effects if the ground water is used for drinking; therefore, access to contaminated ground water should be controlled until further site characterization is completed. Because the land above the plume is privately owned and there are domestic wells in the vicinity, interim institutional controls should be planned and implemented as soon as possible.

For the ground water phase of the UMTRA Project, monitoring of ground water and potential surface expression points should continue until detailed characterization of the site ground water is complete. To resolve outstanding questions about ground water in the alluvium and semiconfined sandstone, better hydrologic and ground water chemistry characterization may be needed. Monitoring of the Little Wind River, including sampling during a low-flow period, may be desirable to assess the potential impact of contaminated floodplain 
ground water on river water quality. Additional sampling will help to better evaluate the potential for ecological impact. Such additional characterization will be discussed in future Riverton ground water documents and work plans. 


\subsection{LIST OF CONTRIBUTORS}

The following individuals contributed to the preparation of this report.

\begin{tabular}{ll}
\hline Name & Contribution \\
\hline C. H. Day & Document coordination \\
A. Groffman & Geochemistry \\
K. Smith & Statistics \\
E. Timmer & Ecological assessment \\
D. Tarbox & Hydrogeology \\
M. Gawthrop & Institutional controls \\
L. Keith, WCl & Text processing \\
E. Bond & Graphic design \\
J. Torline, V. Beck & Technical editing \\
D. Thalley & Document production coordination \\
\hline
\end{tabular}




\subsection{REFERENCES}

Aiyar, A. S., and A. Sreenivasan, 1961. "Effect of Vanadium Administration on Coenzyme Q Metabolism in Rate," in Proc. Sauce. Exp. Biol. Med., Vol. 107, pp. 914-916.

Alexander et al. (F. W. Alexander, B. E. Clayton, and H. T. Delves), 1974. "Mineral and Trace-metal Balances in Children Receiving Normal and Synthetic Diets," in Q.J. Med., Vol. 43, pp. 89-111.

Allison et al. (J. D. Allison, D. S. Brown, and K. J. Novo-Gradac), 1991. MINTEOA2/PRODEFA2, A Geochemical Assessment Model for Environmental Systems: Version 3.0 User's Manual, EPA/600/3-91/021, Environmental Research Laboratory, Office of Research and Development, U.S. Environmental Protection Agency, Athens, Georgia.

Baes et al. (C. F. Baes III, R. D. Sharp, A. L. Sjoreen, and R. W. Shor), 1984. A Review and Analysis of Parameters for Assessing Transport of Environmentally Released Radionuclides through Agriculture, ORNL-5786, prepared for Oak Ridge National Laboratory, Health and Safety Research Division, Oak Ridge, Tennessee.

Ballou et al. (J. E. Ballou, R. A. Gies, A. C. Case, D. L. Haggar, R. L. Buschbom, and J. L. Ryan), 1986. "Deposition and Early Disposition of Inhaled Uranium-233 Uranyl Nitrate and Uranium-232 Uranyl Nitrate in the Rat," in Health Physics, Vol. 51, pp. 755-772.

Belehova, B. A., 1969. Scientific Transactions of the Irkutsk State Medical Institute, Vol. 96. pp. 20-23 (in Russian).

Berlin, M., and B. Rudell, 1986. "Uranium," in Handbook on the Toxicology of Metals, Volume II, second edition, L. Friberg, G. F. Nordberg, and V. B. Vouk, eds., pp. 647-658, Elsevier Science Publishers, New York, New York.

Buchet et al. (J. P. Buchet, R. Lauwerys, and H. Roels), 1981. "Urinary Excretion of Inorganic Arsenic and its Metabolites after Repeated Ingestion of Sodium Metaarsenite by Volunteers," in International Archives of Occupational and Environmental Health, No. 48, pp. 111-118.

Buchet et al. (J. P. Buchet, H. Roels, and R. Lauwerys), 1980. "Repeated Surveillance of Exposure to Cadmium, Manganese, and Arsenic in School-Age Children Living in Rural, Urban, and Nonferrous Smelter Areas in Belgium," in Environmental Research, No. 22, pp. 95-108.

Byerrum et al. (R. U. Byerrum, R. E. Eckardt, L. L. Hopkins), 1974. Vanadium, National Academy of Sciences, Washington, D.C.

Byrne, A. R., and L. Kosta, 1978. Sci. Total Environ., Vol. 10, pp. 17-30. 
Casarett, L. J., and J. Doull, 1991. Toxicology: The Basic Science of Poisons, fourth edition, M. O. Amdur, J. Doull, and C. D. Klaassen, eds., Pergamon Press, New York, New York.

Casarett, L. J., and J. Doull, 1986. "Toxic Effects of Metals," in Toxicology: The Basic Science of Poisons, third edition, Macmillan Publishing Company, New York, New York.

Cothern, C. R., and W. L. Lappenbusch, 1983. "Occurrence of Uranium in Drinking Water in the United States," in Health Physics, No. 45, pp. 89-99.

Crecelius, E. A., 1977. "Changes in the Chemical Speciation of Arsenic Following Ingestion by Man," in Environmental Health Perspective, No. 19, pp. 147-150.

Curran et al., (G. L. Curran, D. L. Azarnoff, and R. E. Bolinger), 1959. "Effect of Cholesterol Synthesis Inhibition in Norme-cholesteramic Young Men," in J. Clin. Invest., Vol. 38, pp. 1251-1261.

DHHS (U.S. Department of Health and Human Services), 1993a. Toxicological Profile for Arsenic, U.S. Department of Health and Human Services, Atlanta, Georgia.

DHHS (U.S. Department of Health and Human Services), 1993b. Toxicological Profile for Nickel, U.S. Department of Health and Human Services, Atlanta, Georgia.

DHHS (U.S. Department of Health and Human Services), 1992a. Toxicological Profile for Manganese, U.S. Department of Health and Human Services, Atlanta, Georgia.

DHHS (U.S. Department of Health and Human Services), 1992b. Toxicological Profile for Vanadium, U.S. Department of Health and Human Services, Atlanta, Georgia.

DHHS (U.S. Department of Health and Human Services), 1992c. Toxicological Profile for Cobalt, U.S. Department of Health and Human Services, Atlanta, Georgia.

Dimond et al. (E. G. Dimond, J. Caravaca, and A. Benchimol), 1963. "Vanadium: Excretion, Toxicity, Lipid Effect in Man," in American Journal of Clinical Nutrition, Vol. 12, pp. 49-53.

DOE (U.S. Department of Energy), 1994. Programmatic Environmental Impact Statement for the Uranium Mill Tailings Remedial Action Ground Water Project, draft, DOE/EIS-0198, April 1994, prepared by the U.S. Department of Energy, UMTRA Project Office, Albuquerque Operations Office, Albuquerque, New Mexico.

DOE (U.S. Department of Energy), 1991. Remedial Action Plan and Site Design for Stabilization of the Inactive Uranium Mill Tailings Site at Riverton, Wyoming, UMTRA-DOE/AL-050505.0000, September 1991, prepared by the U.S. Department of Energy, UMTRA Project Office. Albuquerque Operations Office, Albuquerque, New Mexico. 
DOE (U.S. Department of Energy), 1987. Environmental Assessment of Remedial Action at the Riverton Uranium Mill Tailings Site, Riverton, Wyoming, DOE/EA-0254, June 1987, prepared by the U.S. Department of Energy, UMTRA Project Office, Albuquerque Operations Office, Albuquerque, New Mexico.

Eisler, R., 1989. Molybdenum Hazards to Fish, Wildlife, and Invertebrates: A Synoptic Review, U.S. Fish and Wildlife Service, Contaminant Hazard Reviews, Report 19, Laurel, Maryland, U.S. Department of the Interior, Washington, D.C.

EPA (U.S. Environmental Protection Agency), 1994. Integrated Risk Information System (IRIS), data base, Office of Research and Development, Washington, D.C.

EPA (U.S. Environmental Protection Agency), 1992a. Toxic Substances Spreadsheet, Region IV, Atlanta, Georgia.

EPA (U.S. Environmental Protection Agency), 1992b. Drinking Water Criteria Document for Sulfate, final, Health and Environmental Criteria Division, Office of Science and Technology, U.S. Environmental Protection Agency.EPA, 1992

EPA (U.S. Environmental Protection Agency), 1989a. Risk Assessment Guidance for Superfund, Vol. I, Human Health Evaluation Manual, EPA/540/1-89/002, Office of Emergency and Remedial Response, Washington, D.C.

EPA (U.S. Environmental Protection Agency), 1989b. Risk Assessment Guidance for Superfund, Vol. II, Environmental Evaluation Manual, EPA/505104/1-89/001, Office of Emergency and Remedial Response, Washington, D.C.

EPA (U.S. Environmental Protection Agency), 1988. Interim Sediment Quality Criteria Values for Nonpolar Hydrophobic Organic Contaminants, Office of Water Regulations and Standards, Washington, D.C.

EPA (U.S. Environmental Protection Agency), 1986. "Quality Criteria for Water," EPA 440/5-86-001, Office of Regulations and Standards, Washington, D.C.

EPA (U.S. Environmental Protection Agency), 1984. Health Assessment Document: Inorganic Arsenic, U.S. Environmental Protection Agency, Washington, D.C.

EPA (U.S. Environmental Protection Agency), 1977. Scientific and Technical Assessment Report on Vanadium, EPA-600-6-77-002, U.S. Environmental Protection Agency, Washington, D.C.

EPA (U.S. Environmental Protection Agency), 1972. Water Quality Criteria, National Academy of Sciences and National Academy of Engineering, Washington, D.C.

Ferm, V. H., 1971. "The Teratogenic Profile of Sodium Arsenate in the Golden Hamster," in Archives of Environmental Health, No. 22, pp. 557-560. 
Fisenne et al. (I. M. Fisenne, P. M. Perry, and N. H. Harley, 1988. "Uranium in Humans," in Rad. Prot. Dosim., Vol. 24, pp. 127-131.

Follett, R. H., and P. N. Soltanpour, 1985. "Irrigation Water Quality Criteria," Colorado State University Extension Service publication number 506.

Friberg et al. (L. Friberg, G. F. Nordberg, and V. B. Vouk), 1986. Handbook on the Toxicology of Metals, Volume II: Specific Metals, second edition, Elsevier, New York, New York.

Gosselin et al. (R. E. Gosselin, H. C. Hodge, and R. P. Smith), 1976. Clinical Toxicology of Commercial Products, fourth edition, Williams and Wilkins, Baltimore, Maryland.

Goyer, Robert A., 1991. "Toxic Effects of Metals," in Toxicology: The Basic Science of Poisons, fourth edition, pp. 623-680, M. O. Amdur, J. Doull, and C.D. Klaassen, eds., Pergamon Press, New York, New York.

Hadjimarkos, D. M., 1968. Adv. Oral Biol., Vol. 3, pp. 253-292.

Hadjimarkos, D. M., 1966. "Vanadium and Dental Caries," in Nature, Vol. 209, pp. 1137.

Harris et al. (W. R. Harris, S. B. Friedman, and D. Silberman), 1984. J. Inorg. Biochem., Vol. 20, pp. 157-169.

Hart, G., 1993. Wind River Environmental Quality, Ft. Washiki, personal communication to Malu Gawthrop Cooper, Regulatory Compliance Department, Jacobs Engineering Group Inc., Albuquerque, New Mexico, UPDCC File Location No. 7.19.7. July 26, 1993.

Hood, R. D., 1972. "Effects of Sodium Arsenite on Fetal Development," in Bulletin of Environmental Contamination and Toxicology, No. 7, p. 216.

ICRP (International Commission on Radiological Protection), 1960. ICRP Pub/., 2.

Ishinishi et al. (N. Ishinishi, K. Tsuchiya, M. Vahter, and B. A. Fowler), 1986. "Arsenic," in Handbook on the Toxicology of Metals, Volume II: Specific Metals, second edition, Elsevier Press, Amsterdam-New York-Oxford.

Israeli, M., and C. B. Nelson, 1992. "Distribution and Expected Time of Residence for U.S. Households," in Risk Analysis, Vol. 12, No. 1, pp. 65-72.

Kabata-Pendias, A., and H. Pendias, 1992. Trace Elements in Soils and Plants, second edition, CRC Press, Boca Raton, Florida.

Kondakis et al. (X. G. Kondakis, N. Makris, M. Leotsinidis, M. Prinou, and T. Papapetropoulos), 1989. "Possible Health Effects of High Manganese Concentration in Drinking Water," in Archives of Environmental Health, Vol. 44, No. 3, pp. 175-178. 
Lagerkvist et al. (B. Lagerkvist, G. F. Nordberg, and V. Vouk), 1986. "Vanadium," in Handbook on the Toxicology of Metals, second edition, L. Friberg, G. F. Nordberg, and V. Vouk, eds., Elsevier Science Publishers, New York, New York.

Leach et al. (L. J. Leach, R. M. Gelein, B. J. Panner, C. L. Ylie, and C. C. Cox), 1984. The Acute Toxicity of the Hydrolysis Products of Uranium Hexafluoride $\left(U F_{6}\right)$ When Inhaled by the Rat and Guinea Pig, final report, ISS K/SUB-81-9039-3, NTIS DE84011539.

Lindgren et al. (A. Lindgren, M. Vahter, and L. Dencker), 1982. "Autoradiographic Studies on the Distribution of Arsenic in Mice and Hamsters Administered ${ }^{74}$ As-arsenite or -arsenate," in Acta Pharmacology and Toxicology, No. 51, pp. 253-265.

Lönnerdal et al. (B. Lönnerdal, C. L. Keen, J. G. Bell, and B. Sandstrom), 1987. "Manganese Uptake and Retention," in Nutritional Bioavailability of Manganese, C. Kies, ed., American Chemical Society, symposium series 354, pp. 9-20, American Chemical Society, Washington, D.C.

Marafante, E., and M. Vahter, 1987. "Solubility, Retentions and Metabolism of Intratracheally and Orally Administered Inorganic Arsenic Compounds in Hamsters," in Environmental Research, No. 42, pp. 72-82.

Marcus, W. L., and A. S. Rispin, 1988. "Threshold Carcinogenicity Using Arsenic as an Example," in Advances in Environmental Toxicology, Volume XV, Risk Assessment and Risk Management of Industrial and Environmental Chemicals, pp. 133-159, C. R. Cothern, M. A. Mehlman, and W. L. Marcus, eds., Princeton Scientific Publishing Co., New Jersey.

Maynard, E. A., and H. C. Hodge, 1949. "Study of Toxicity of Various Uranium Compounds When Fed to Experimental Animals," in Pharmacology and Toxicology of Uranium Compounds, National Nuclear Energy Services, Div. VI, Vol. 1, pp. 309-376, C. Voegtlin and H. C. Hodge, eds., McGraw Hill, New York, New York.

Mena et al. (I. Mena, K. Horiuchi, K. Burke, and G. C. Cotzias), 1969. "Chronic Manganese Poisoning, Individual Susceptibility and Adsorption of Iron," in Neurology, Vol. 19, pp. 1000-1006.

Morrison et al. (G. M. P. Morrison, G. E. Batley, and T. M. Florence), 1989. "Metal Speciation and Toxicity," in Chem. Br., No. 25, p. 791.

National Research Council, 1973. Medical and Biological Effects of Environmental Pollutants: Manganese, Committee on Biologic Effects of Atmospheric Pollutants, Division of Medical Sciences.

National Research Council, 1971. Nutrient Requirements of Dairy Cattle, Committee on Animal Nutrition, fourth edition, The National Academy of Science, Washington, D.C. 
NCRP (National Council on Radiation Protection and Measurements), 1984. Exposure From the Uranium Series With Emphasis on Radon and Its Daughters, NCRP Report 77, Bethesda, Maryland.

NOAA (National Oceanic and Atmospheric Administration), 1990. "The Potential for Biological Effects of Sediment-Sorbed Contaminants Tested in the National Status and Trends Program," NOAA technical memo, NOS OMA 52.

NUREG (Nuclear Regulatory Agency), 1986. "Update of Part 61, Impacts Analysis Methodology," Division of Waste Management, Office Nuclear Material Safety and Safeguards, NUREG/CR-437, Vol. 1.

Parkhurst et al. (D. L. Parkhurst, D. C. Thorstenson, and D. N. Plummer), 1980. PHREEQE-A Computer Program for Geochemical Calculations, U.S. Geological Survey, Water Resources Investigation 80-96, National Technical Information Services Report PB81-167-801, Springfield, Virginia.

Pennington, J. A., and J. W. Jones, 1987. "Molybdenum, Nickel, Cobalt, Vanadium, and Strontium in Total Diets," in Journal of the American Dietetic Association, Division of Nutrition and Division of Contaminants Chemistry, Center for Food Safety and Applied Nutrition, Food and Drug Administration, Vol. 87, No. 12, December 1987, Washington, D.C.

Perry et al. (H. M. Perry, Jr., S. Teitlebaum, and P. L. Schwartz), 1955. "Effects of Antihypertensive Agents on Amino Acid Decarboxylation and Amino Oxidation," in Fed. Proc., Vol. 14, pp. 113-114.

Pershagen, G., and M. Vahter, 1979. Arsenic, Swedish Environmental Protection Board, Stockholm, Sweden.

Prister, B. S., 1969. GKIAE Report by Atomizdat, Moscow (Canadian translation AEC/TR/7178 (1970), and USCEAR Rep. A/AC.82/G/L 1298).

Proescher et al. (F. Proescher, H. A. Seil, and A. W. Stillians), 1917. Am. J. Syph., Vol. 1, pp. 347-405.

Robinson et al. (M. F. Robinson, J. M. McKenzie, C. Thomson, and A. L. Van Rijn), 1973. Br. J. Nutr., Vol. 30, pp. 195-205.

Roseberry, A. M., and D. E. Burmaster, 1992. "Lognormal Distributions for Water Intake by Children and Adults," in Risk Analysis, Vol. 12, No. 1, pp. 99-104.

Rosoff, B., and H. Spencer, 1964. Nature (London), Vol. 202, pp. 410-411.

Saric, M., 1986. "Manganese," Handbook on the Toxicology of Metals, Volume II, L. Friberg, G. F. Nordberg, and V. B. Vouk, eds., Elsevier, New York, pp. 354-386. 
Schroeder et al. (H. A. Schroeder, J. J. Balassa, and I. H. Tipton), 1963. J. Chronic Dis., $16,1047-1071$.

Shannon, R. L., and D. S. Strayer, 1989. "Arsenic-Induced Skin Toxicity," in Human Toxicology, No. 8, pp. 99-104.

Snyder, F., and W. E. Cornatzer, 1958. "Vanadium Inhibition of Phospholipid Synthesis and Sulphydryl Activity in Rat Liver, in Nature, Vol. 182, pp. 462.

Somerville, J., and B. Davies, 1962. Am. Heart J., Vol. 64, pp. 54-56.

Stevens et al. (W. F. Stevens, W. Bruenger, D. R. Atherton, J. M. Smith and G. N. Taylor), 1980. "The Distribution and Retention of Hexavalent ${ }^{23} U$ in the Beagle," in Radiat. Res., Vol. 83, pp. 109-126.

Stockdale, D, 1993. State Engineer's Groundwater Office, Cheyenne, Wyoming, personal communication to Malu Gawthrop Cooper, Regulatory Compliance Department, Jacobs Engineering Group Inc., Albuquerque, New Mexico, UPDCC File Location No. 7.19.7, July 26, 1993.

Sullivan et al. (M. F. Sullivan, P. S. Ruemmler, J. L. Ryan, and R. L. Bushhom), 1986. "Influence of Oxidizing or Reducing Agents on Gastrointestinal Absorption of $U$, Pu, Am, Cm, and Pm by Rats," in Health Physics, Vol. 50, pp. 223-232.

Tank, G., and C. A. Storvick, 1960. "Effect of Naturally Occurring Selenium and Vanadium on Dental Caries," in J. Dent. Res., Vol. 39, pp. 473-488.

Tipton, I. H., and M. J. Cook, 1963. "Trace Elements in Human Tissue, Part II, Adult Subjects from the United States," in Health Physics, Vol. 9, pp. 103-145.

Tracy et al. (B. L. Tracy, J. M. Quinn, J. Lahey, A. P. Gilman, K. Mancuso, A. P. Yagdinas, and D. C. Villeneuvel, 1992. "Absorption and Retention of Uranium from Drinking Water by Rats and Rabbits," in Health Physics, Vol. 62, pp. 65-73.

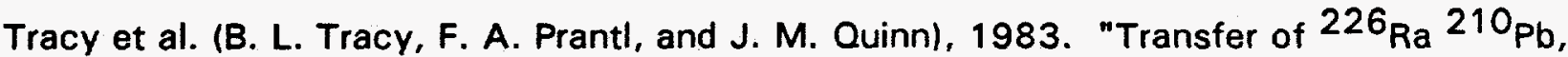
and Uranium from Soil to Garden Produce: Assessment of Risk," in Health Physics, Vol. 44, p. 469.

Tseng, W. P., 1977. "Effects and Dose-Response Relationship of Skin Cancer and Blackfoot Disease with Arsenic," in Environmental Health Perspectives, No. 19 , pp. 109-119.

Van Zinderen Bakker and J. F. Jaworski, 1980. Effects of Vanadium in the Canadian Environment, Ottawa, Canada: National Research Council Canada, Associate Committee Scientific Criteria for Environmental Quality.

WDEQ (Wyoming Department of Environmental Quality), 1990. Water Quality Rules and Regulations, Chapter I, Quality Standards for Wyoming Surface Waters. 
Webb, J. L., 1966. Enzymes and Metabolic Inhibitors, Academic Press, New York, New York.

Weigel, F., 1983. "Uranium and Uranium Compounds," Kirk-Othmer Encyclopedia of Chemical Technology, Vol. 23, third edition, pp. 502-547, M. Grayson, ed., John Wiley and Sons, New York, New York.

WHO (World Health Organization), 1988. Vanadium, Environmental Health Criteria 81, published under the joint sponsorship of the United Nations Environment Programme, the International Labour Organisation, and the World Health Organization, Geneva, Switzerland.

WHO (World Health Organization), 1981. Arsenic, Environmental Health Criteria 18, published under the joint sponsorship of the United Nations Environment Programme, the International Labour Organisation, and the World Health Organization, Geneva, Switzerland.

Wrenn et al. (M. E. Wrenn, P. W. Durbin, B. Howard, J. Lipsztein, J. Rundo, E. T. Still, and D. L. Willis), 1985. "Metabolism of Ingested $U$ and Ra," in Health Physics, Vol. 48 , pp. 601-633.

Yakawa, M., and M. Suzuki-Yasumoto, 1980. "Distribution of Trace Elements in the Human Body Determined by Neutron Activation Analysis," in Arch. Environ. Health, Vol. 35, pp. 36-44.

\section{CODE OF FEDERAL REGULATIONS}

40 CFR Part 192, Health and Environmental Protection Standards for Uranium and Thorium Mill Tailings, U.S. Environmental Protection Agency (1994).

\section{UNITED STATES CODE}

42 USC $\$ 7901$ et seq.. Uranium Mill Tailings Radiation Control Act, November 8, 1978. 